\title{
Exploring the Coordination \\ Potential of Monodentate and \\ Bidentate Bicyclic Guanidine \\ Ligands
}

by

Cara Alice Luiten

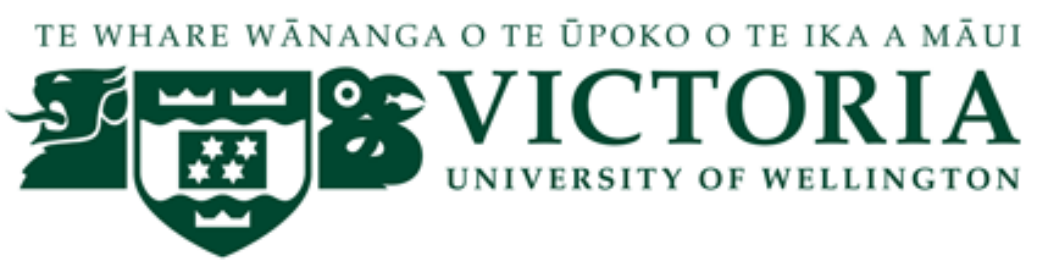

\begin{abstract}
A thesis
submitted to Victoria University of Wellington in partial fulfilment of the requirements for the degree of Master of Science in Chemistry
\end{abstract}

Victoria University of Wellington 2018 


\section{Abstract}

This thesis reports investigations of the interaction of arene-bicyclic guanidine ligands, using the 1,3,4,6,7,8-hexahydro-2H-pyrimido[1,2a]pyrimidine $(\mathrm{hppH})$ guandine (Figure i) as a foundation, with a variety of metal centres. Beginning with 1-benzyl-1,3,4,6,7,8-hexahydro- $2 H^{-}$ pyrimido[1,2-a]pyrimidine $\left(\mathrm{Ph}\left(\mathrm{CH}_{2} \mathrm{hpp}\right)\right)$, attempts were made to coordinate this ligand to group 1 metal $\mathrm{N}\left\{\mathrm{SiMe}_{3}\right\}_{2}^{-}$salts, which resulted in a novel $\mathrm{NaN}\left\{\mathrm{SiMe}_{3}\right\}_{2}$ crystal structure. Ligands comprised of a phenyl group with multiple hpp units in varying substitution patterns were also synthesised and reacted with group 1 metal $\mathrm{N}\left\{\mathrm{SiMe}_{3}\right\}_{2}{ }^{-}$salts to investigate the possibility of bidentate and tridentate arene-hpp coordination. This resulted in the synthesis of two novel compounds containing $\mathrm{KN}\left\{\mathrm{SiMe}_{3}\right\}_{2}$. Both $\sigma$ and $\pi$-interactions with potassium were observed in the crystal structure of one of these compounds. NMR data that support analogous coordination to lithium and sodium analogues were also obtained.

The ligands with multiple hpp units were introduced to highly reactive main group antinomy and bismuth species in an attempt to achieve a coordination with increased hapticity of the $\pi$ interaction. A novel antimony structure was obtained with asymmetric coordination of an arene-hpp ligand in which an intramolecular $\mathrm{C}-\mathrm{H}$ activation was achieved.

An N-phosphino guaninde was synthesised and employed in this research due its potential to coordinate through both its available nitrogen and phosphorus atoms. This ligand was reacted with a variety of metal centres which revealed information about the strength of the $\mathrm{N}-\mathrm{P}$ bond in the ligand. Two novel crystal structures were obtained which both contained novel group 1 clusters with coordinating hpp units. 
Finally, attempts were made to coordinate $\mathrm{Ph}\left(\mathrm{CH}_{2} \mathrm{hpp}\right)$ to transition metal halides and $\mathrm{N}\left\{\mathrm{SiMe}_{3}\right\}_{2}{ }^{-}$salts. These attempts resulted in one novel crystal structure.

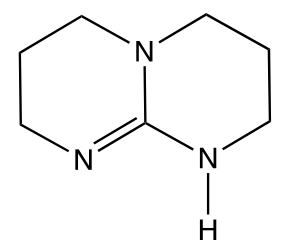

Figure i:

1,3,4,6,7,8-hexahydro-2H-pyrimido[1,2-a]pyrimidine (hppH) 


\section{Acknowledgements}

I would firstly like to thank Associate Professor Martyn Coles for all his enthusiasm, encouragement, knowledge, and crystallography skills. This thesis would not have been possible without your assistance and support.

I would also like to acknowledge Dr Robin Fulton and the members of the Fulton and Coles research groups for your help. Ryan, Mat, Struan, Peter, Grace, Dylan, Christoph, Esther, Putri, Loc, and Amanda - you have made this project an exciting endeavour.

Thank you to my Dad, my sister Christine, and my boyfriend Fraser - I would not be where I am today without all that you have done for me. 


\section{Table of Contents}

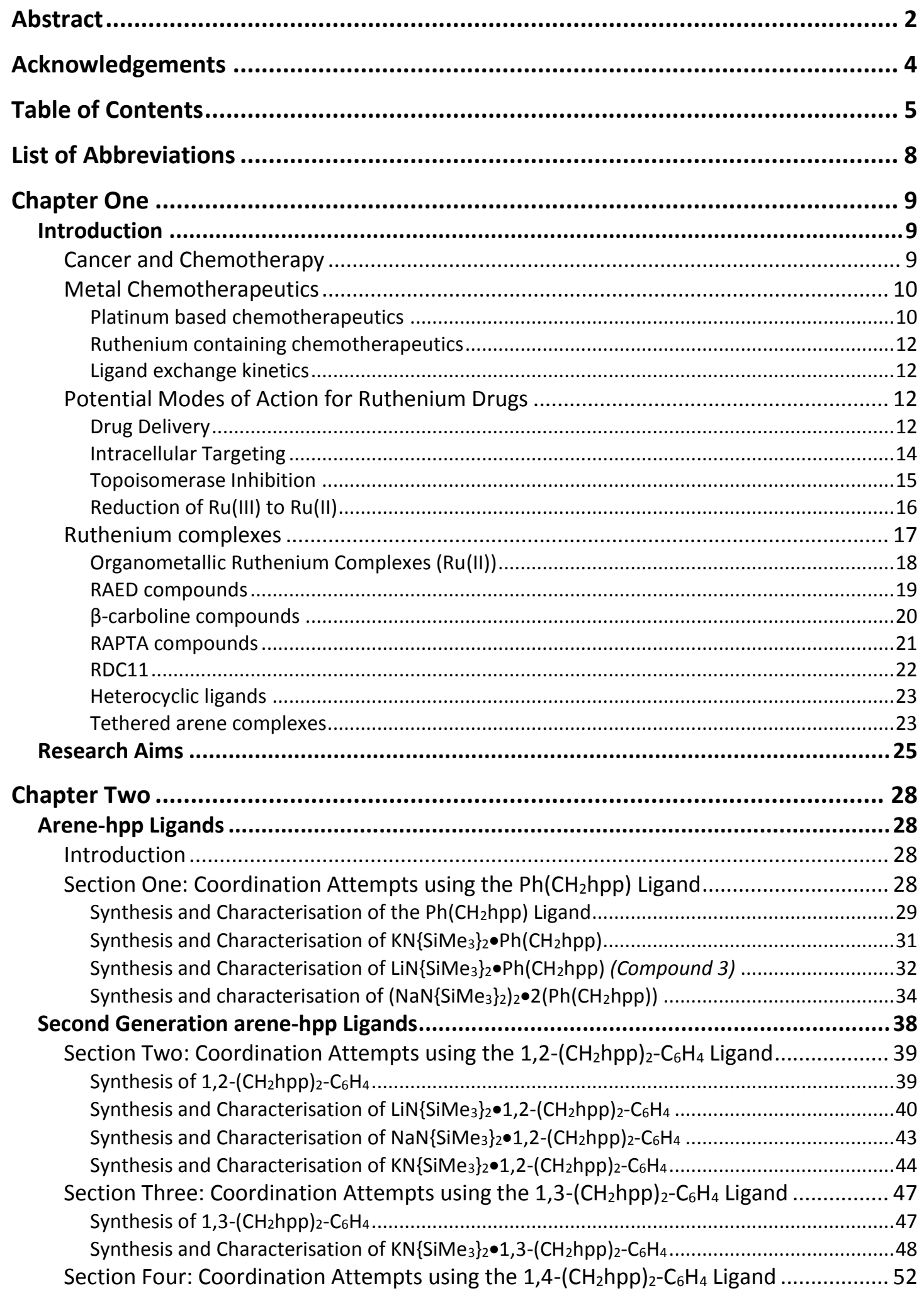




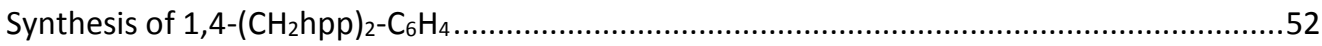

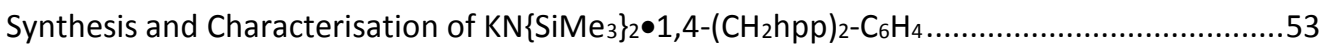

Section Five: Coordination Attempts using the 1,3,5-( $\left.\mathrm{CH}_{2} \mathrm{hpp}\right)_{3}-\mathrm{C}_{6} \mathrm{H}_{3}$ Ligand ............. 54

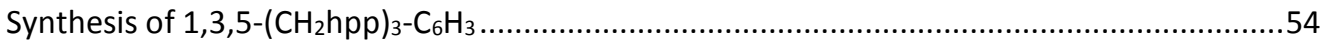

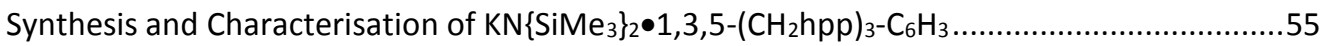

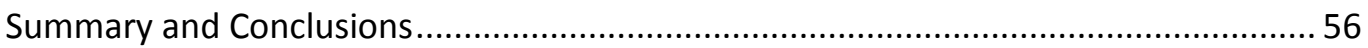

Chapter Three ........................................................................................ 58

Coordination Attempts of Arene-hpp Ligands with Pnictogens .............................58

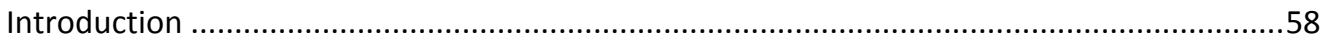

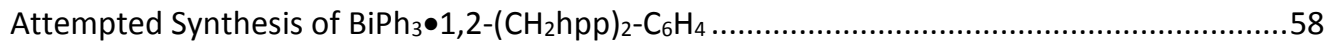

Attempted Synthesis and Characterisation of $\mathrm{BiCl}_{2} \mathrm{Ph} \bullet 1,2-\left(\mathrm{CH}_{2} \mathrm{hpp}\right)_{2}-\mathrm{C}_{6} \mathrm{H}_{4}$ (Compound 15) ...60

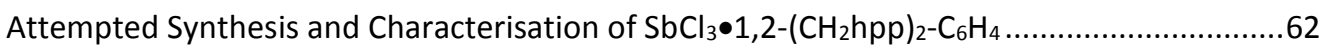

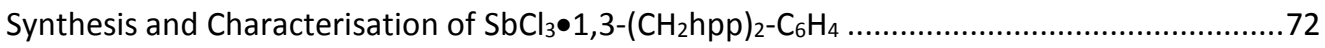

Summary and Conclusions.......................................................................... 74

Chapter Four.......................................................................................... 75

N-phosphino guanidines.............................................................................. 75

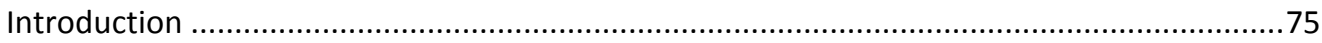

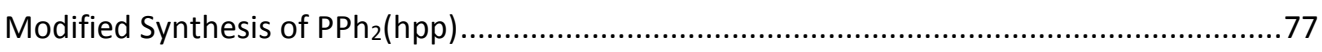

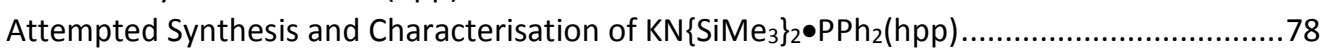

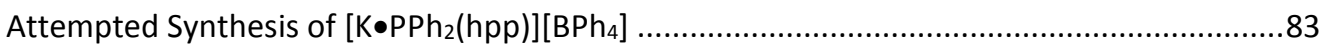

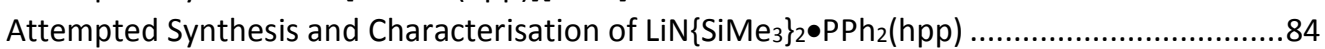

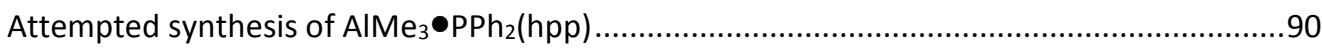

Summary and Conclusions.......................................................................... 94

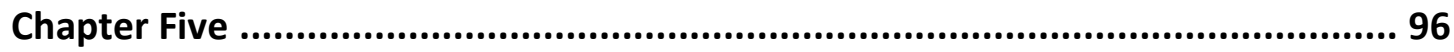

Attempted Coordination of Arene-hpp Ligands to Transition Metals ........................96

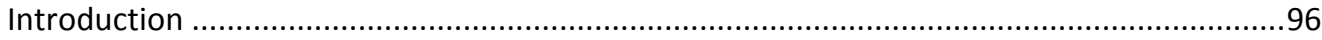

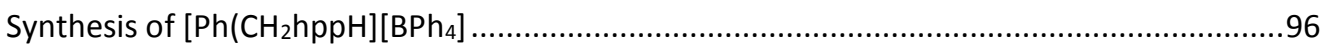

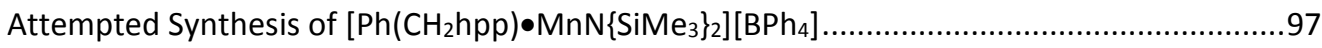

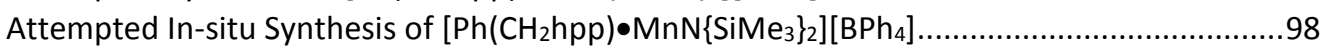

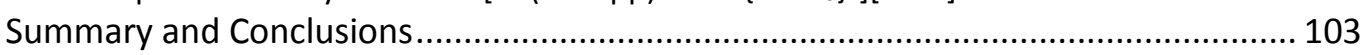

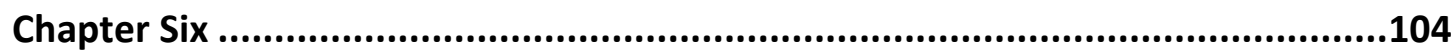

Concluding Remarks.......................................................................... 104

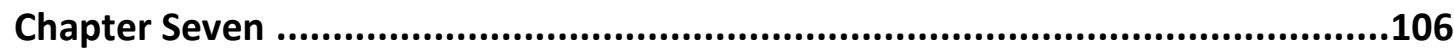

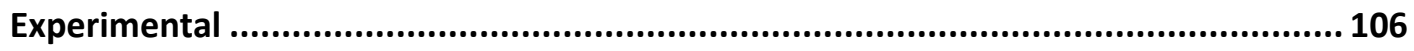

General Considerations ............................................................................... 106

Experimental Detail for Chapter 2 .................................................................. 107

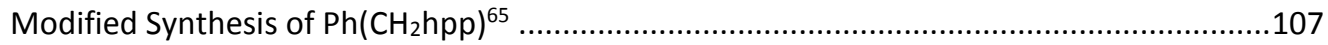

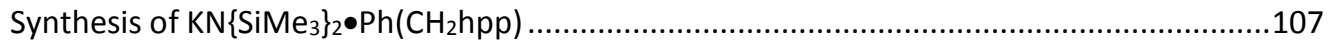

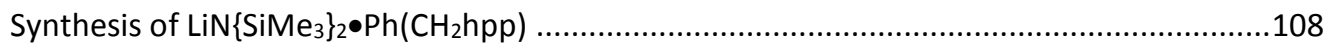

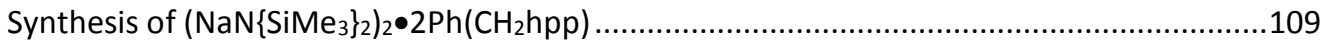

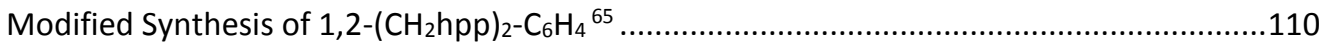

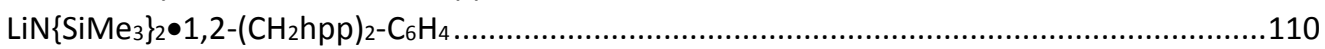

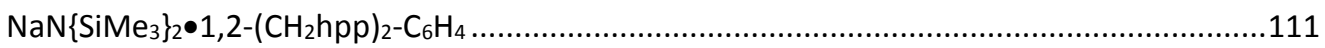

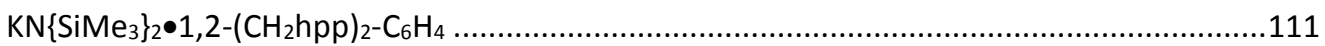

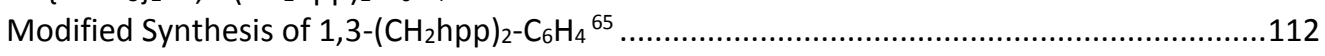

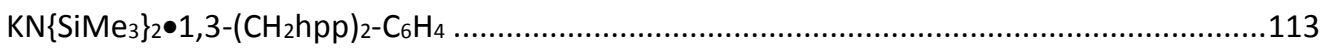

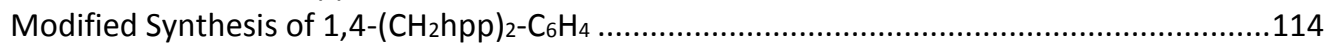

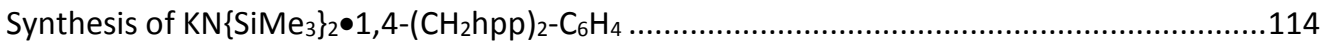

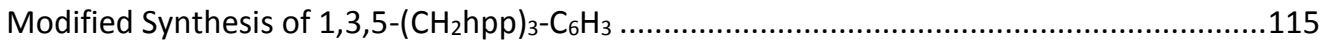

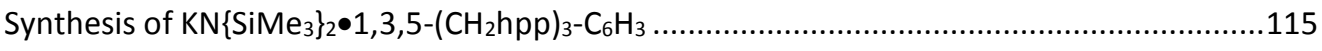

Experimental Detail from Chapter 3 ............................................................ 116 


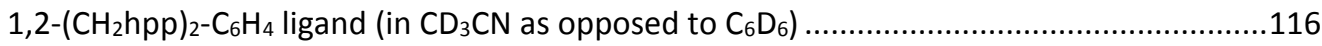

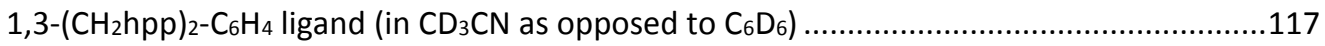

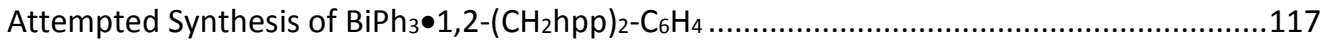

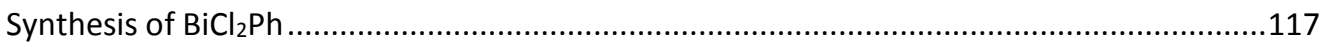

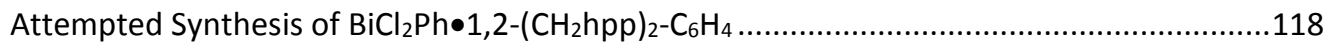

Attempted Synthesis of $\mathrm{SbCl}_{3} \bullet 1,2-\left(\mathrm{CH}_{2} \mathrm{hpp}\right)_{2}-\mathrm{C}_{6} \mathrm{H}_{4}$ consequent synthesis of $\mathrm{Sb}[\kappa-\mathrm{C}, \mathrm{N}-1-$

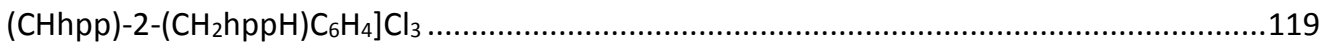

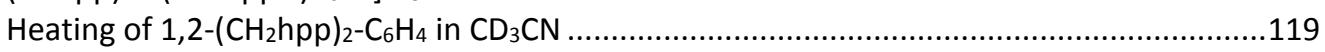

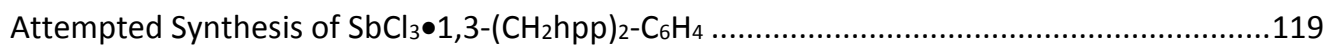

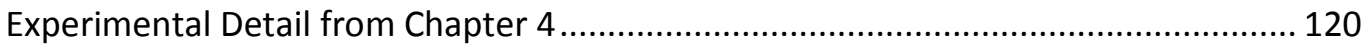

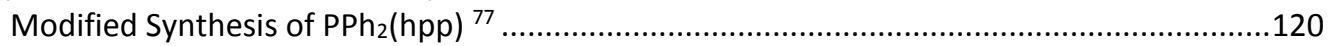

Attempted Synthesis of $\mathrm{KN}\left\{\mathrm{SiMe}_{3}\right\}_{2} \bullet \mathrm{PPh}_{2}(\mathrm{hpp})$ and Consequent Synthesis of $\left[\mathrm{K}_{10}(\mathrm{hpp})_{8}\right]^{2+} .121$

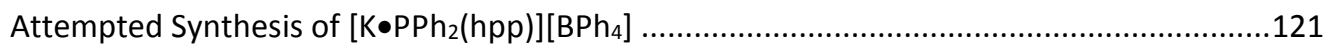

Attempted Synthesis of $\mathrm{LiN}\left\{\mathrm{SiMe}_{3}\right\}_{2} \bullet \mathrm{PPh}_{2}(\mathrm{hpp})$ and Consequent Synthesis of

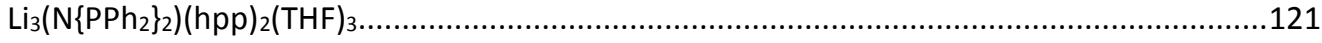

Attempted synthesis of $\mathrm{AlMe}_{3} \bullet \mathrm{PPh}_{2}(\mathrm{hpp})$ and Consequent Synthesis of $\left\{(\mu-\mathrm{hpp})-\mathrm{AlMe}_{2}\right\}_{2} . .122$

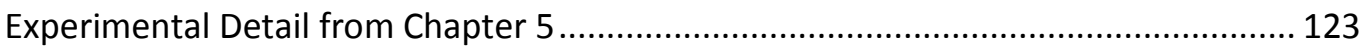

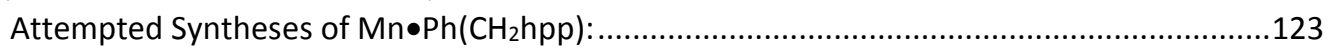

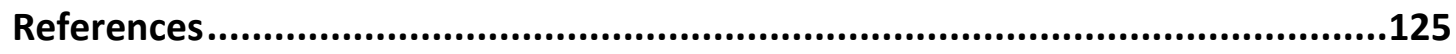

Appendix One - Crystallographic Data........................................................129

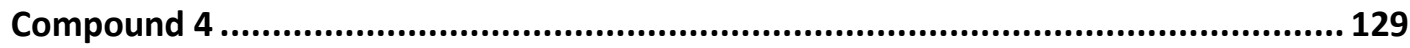

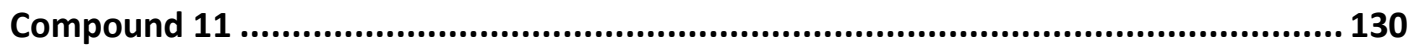

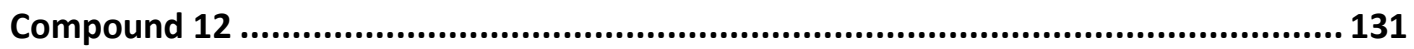

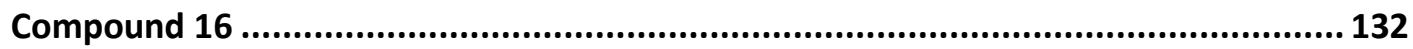

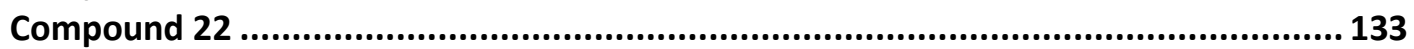

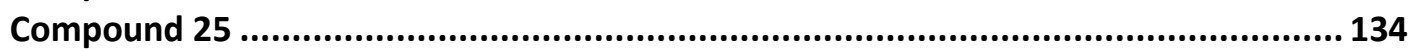

Appendix Two $-{ }^{1}$ H NMR Data of Notable Compounds ....................................135

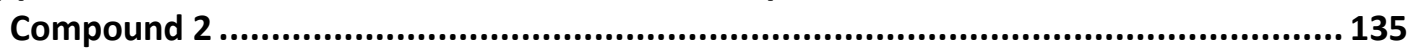

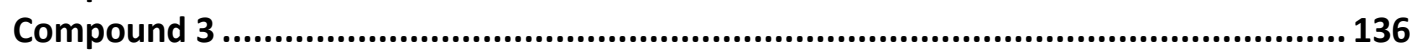

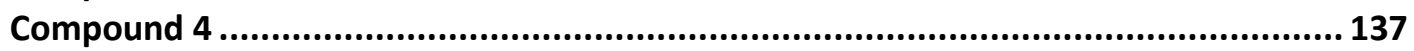

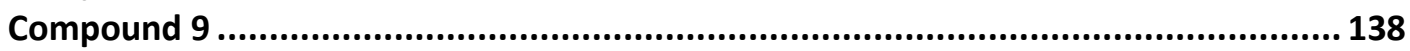

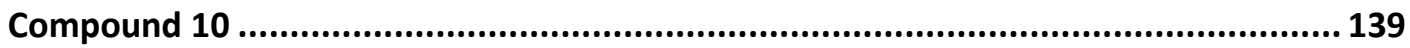

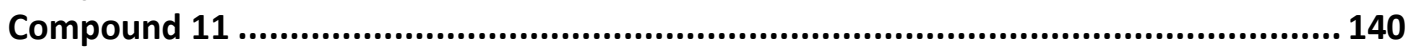

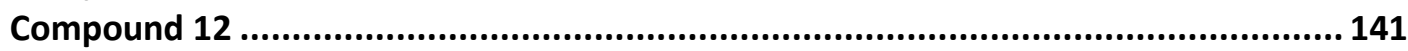

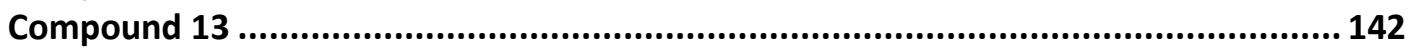

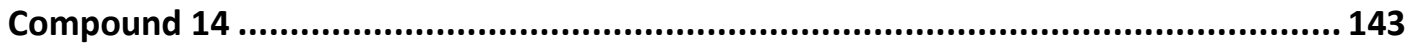

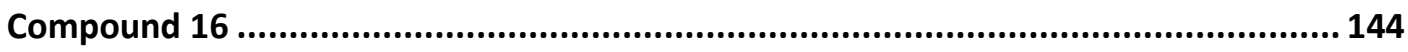

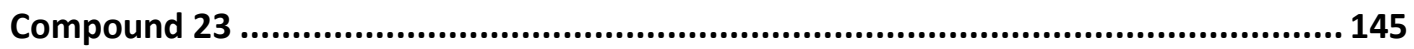




\section{List of Abbreviations}

$\begin{array}{ll}\delta & \text { Chemical shift (ppm) } \\ { }_{13} \mathrm{C} \text { NMR } & \text { Carbon nuclear magnetic resonance } \\ { }^{1} \mathrm{H} \text { NMR } & \text { Hydrogen nuclear magnetic resonance } \\ 31 \mathrm{P} \mathrm{NMR} & \text { Phosphorus nuclear magnetic resonance } \\ \text { br } & \text { broad } \\ \mathrm{C}_{6} \mathrm{D}_{6} & \text { Deuterated benzene } \\ \mathrm{CD}_{3} \mathrm{CN} & \text { Deuterated acetonitrile } \\ \mathrm{d} & \text { Doublet } \\ \mathrm{DFT} & \text { Density functional theory } \\ \mathrm{DME} & \text { Dimethoxyethane } \\ \mathrm{Et}{ }_{2} \mathrm{O} & \text { Diethyl ether } \\ \mathrm{hppH} & 1,3,4,6,7,8 \text {-hexahydro-2H-pyrimido[1,2-a]pyrimidine } \\ \mathrm{Hz} & \text { Hertz } \\ J & \text { Scalar coupling constant (Hz) } \\ \mathrm{m} & \text { multiplet } \\ \mathrm{n}-\mathrm{Bu} & n \text {-butyl } \\ \mathrm{Ph} & \text { phenyl } \\ \mathrm{ppm} & \text { Parts per million } \\ \mathrm{NMR} & \text { Nuclear magnetic resonance spectroscopy } \\ \text { quin } & \text { quintet } \\ \mathrm{RT} & \text { Room temperature } \\ \mathrm{s} & \text { Singlet } \\ \mathrm{t} & \text { Triplet } \\ t-\mathrm{Bu} & \text { tert-butyl } \\ \mathrm{THF} & \text { Tetrahydrofuran } \\ & \end{array}$




\section{Chapter One}

\section{Introduction}

\section{Cancer and Chemotherapy}

Cancer is one of the leading causes of death worldwide. There were over 8 million cancer related deaths in 2012 alone. ${ }^{1}$ All types of cancer acquire the same characteristics; an idea first proposed by Hanahan and Weinberg in the 2000 review article 'The Hallmarks of Cancer'. ${ }^{2}$ These characteristics include being immune to anti-growth signals, being able to replicate indefinitely, promotion of angiogenesis - the formation of new blood vessels in response to increasing oxygen demands, evading apoptosis (cell induced cell death) and the ability to metastasise - leaving the primary tumour site and growing a tumour elsewhere. ${ }^{2}$

Cancer cells develop these hallmarks through a series of genetic changes. Our cells contain proto-oncogenes that code for proteins that control regular processes. Proto-oncogenes can become oncogenes through mutation or amplification. Over expression of oncogenes leads to excessive signalling for cell division and growth. ${ }^{3}$ Furthermore, cells have tumour suppressor genes. These provide defence against developing cancer. However, the mutation and subsequent loss of activity of a tumour suppressor gene can contribute towards the loss of cellular abilities such as repairing DNA damage and the presence of checkpoints in the cell cycle. ${ }^{4}$ The coupling of oncogene over expression and tumour suppressor inactivity allows for normal cells to turn cancerous.

Among the possible treatments for cancer is chemotherapy, a method of attacking cancerous cells using toxic compounds. This has been shown to work on metastatic cancer, an advantage over surgical removal of tumours 
and radiation therapy. ${ }^{5}$ Chemotherapy drugs work in different ways, generally by targeting one or more of the hallmarks of cancer. Current chemotherapeutics have serious side effects because they also target healthy fast proliferating cells. This could be remedied by the use of more specific chemotherapeutics that only target cancerous cells in the body. ${ }^{6}$

\section{Metal Chemotherapeutics}

There are complexes of many transition metals being studied as potential chemotherapeutics including platinum, ruthenium, rhodium, iridium and rhenium. ${ }^{7}$

\section{Platinum based chemotherapeutics}

The first metal chemotherapy agent cis-diamminedichloridoplatinum(II); commonly known as Cisplatin, was discovered to have anti-tumour properties by Rosenberg et al. in $1969 .{ }^{8}$ Cisplatin is a very effective drug in the treatment of testicular cancer and can be used to treat other cancers such as ovarian, oesophageal and cervical. ${ }^{9}$ Cisplatin is now used in almost half of the chemotherapy treatments for tumorous cancer. ${ }^{10}$ The antitumoural efficacy of Cisplatin is because the complex damages DNA in fast replicating cells in the body. The damage caused by Cisplatin disables replication and transcription of DNA. Therefore, tumour growth and protein production ceases, leading to cell death by apoptosis. ${ }^{11}$

There are other platinum based chemotherapy drugs in clinical use including Carboplatin and Oxaliplatin (See Figure 1 for structures). All of the 'platin' drugs are pro-drugs, meaning they are not active until ligand substitution occurs upon entering the cell. These platinum pro-drugs consist of both labile ligands and carrier ligands. The labile ligands are either chloride or carboxylate based and are substituted by water. The carrier ligands are nitrogen based and remain on the complex throughout 
the entire process. ${ }^{12}$

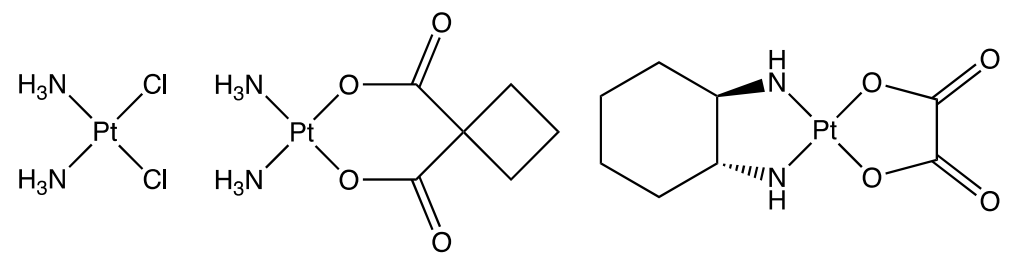

Figure 1: Cisplatin, Carboplatin, and Oxaliplatin (left to right)

The mechanism of DNA damage by a platinum pro-drug begins with the aquation process. This exchange of labile ligands for water is driven by the low concentration of chloride and carboxylate compounds inside the cell compared to outside the cell. The newly substituted complex binds favourably to purines (mainly guanidine but also sometimes adenine). The binding of the complex to strands of DNA leads to intrastrand crossing, where usually a cis-Pt-GG crosslink forms. This causes enough unwinding and bending of the DNA strand to make it unusable for genetic processes in the cell. ${ }^{13}$

However, platinum based chemotherapeutics have a wide range of adverse side effects. These include severe emesis (vomiting and nausea), nephrotoxicity (kidney damage) and neurotoxicity, where damage is caused to the nervous system. ${ }^{11,14}$ These side effects are a result of damaging the DNA in non-cancerous tissue. ${ }^{12}$ In order to reduce side effects, a drug made with a metal that is less toxic to the body than platinum and specific to only cancer cells would be used.

Drug resistant tumours are another undesirable effect of Cisplatin use. Cancer cells can have innate resistance or develop resistance during the chemotherapy treatment. ${ }^{15}$ Mechanisms for resistance include being able to repair the DNA damage induced by the drug or blocking signals for apoptosis after DNA damage has occurred. ${ }^{16}$ 


\section{Ruthenium containing chemotherapeutics}

The development of ruthenium containing chemotherapy drugs begun in 1980. A ruthenium analogue of Cisplatin was synthesised that showed some anti-cancer properties in rats but solubility difficulties prevented this analogue from becoming a chemotherapeutic. ${ }^{7}$

\section{Ligand exchange kinetics}

Importantly, ruthenium and platinum have similar ligand exchange kinetics; their complexes both have a slow rate of ligand exchange. ${ }^{7,}$, 17, 18 In order to be effective against cancer cells, the compound must have a ligand exchange rate similar to the lifetime of a cell. ${ }^{7}$ Both ruthenium and platinum have a ligand exchange rate of $10^{-3}$ to $10^{-2} \mathrm{~s}^{-1} .17$ Changing the ligands on a metal alters the ligand exchange kinetics of a complex. Therefore, different ligands can be trialled until the perfect kinetics are achieved for a ruthenium drug to target a cancer. ${ }^{19}$

Studies synthesising osmium analogues of existing ruthenium drugs, found reduction in anti-cancer ability due to an alteration in the ligand exchange kinetics. $^{20,21}$

\section{Potential Modes of Action for Ruthenium Drugs}

\section{Drug Delivery}

Ruthenium based drugs have been found to target cancerous tissue more selectively in comparison to Cisplatin or organic based chemotherapeutics. ${ }^{22}$ Ruthenium is a rare metal and is below iron in group 
8 of the periodic table. It therefore has a similar electronic structure to iron and can act as an iron homologue in the body. All cells require iron in order to undergo routine metabolic processes. Transferrin is an iron transport protein that enables cells to receive iron in a usable form. Cancerous cells require more iron than healthy cells due to their increased metabolic rate and hence have an increased amount of transferrin receptors on their surface. ${ }^{23}$

Ruthenium complexes have been found to bind to the transferrin protein, which exists in blood serum. ${ }^{24}$ Two Ru(III) chemotherapeutics currently in clinical trials, NAMI-A and KP1019, have been shown to bind to transferrin at histidine residues where iron would usually bind. Multiple iron/ruthenium binding sites exist on apotransferrin (the protein before metal binding). ${ }^{25}$ However, spectroscopic studies on KP1019 show the complex can also enter cells without the aid of transferrin. ${ }^{26}$ Therefore, transferrin is not necessarily the only way a ruthenium drug can enter cells.

When ruthenium complexes bind to transferrin the simple ligands, such as chlorides, dissociate. However, investigation into the binding of $\mathrm{Ru}(\mathrm{III})$ complexes to apotransferrin shows that the binding does not result in the loss of more complex ligands (eg. heterocycles). This differs to the mechanism in which Fe(III) complexes bind to apotransferrin and lose all their ligands upon binding. ${ }^{27}$ The uptake of ruthenium complexes by cells occurs at a higher rate when iron is present and some of the transferrin proteins already have iron in their binding sites. ${ }^{28}$ As transferrin has multiple binding sites it is likely that the protein's conformation changes upon the binding of some iron making the binding to other sites more accessible.

The high amount of transferrin receptors on the surface of cancerous cells will allow for selective transport of the ruthenium complexes (bound to transferrin) into cancerous cells and less so into healthy cells with less 
transferrin receptors. This is why ruthenium complexes are viewed as less toxic to the rest of the body compared to their platinum counterparts. ${ }^{18}$

Furthermore, as transferrin is a serum protein present in the blood, ruthenium complexes will bind to transferrin when they arrive in the blood stream limiting toxicity of the drug to the rest of the body until transported and released directly into the cancerous cells. ${ }^{29}$

\section{Intracellular Targeting}

Ruthenium complexes have been known to target DNA but they bind to DNA in a different way to Cisplatin. ${ }^{30}$ It is important to have a mode of action different from that of the platin chemotherapeutics so the ruthenium drugs synthesised can be used on platin resistant tumours.

The $\mathrm{Ru}$ (III) complexes shown to have anti-cancer properties have a higher affinity for cellular proteins than for DNA and it is likely that many of these compounds target cell functioning by binding to cellular proteins as opposed to explicitly targeting DNA. ${ }^{25}$ Neither of the Ru(III) drugs in clinical trials, NAMI-A or KP1019, (Figure 2) function as chemotherapeutic agents primarily by a DNA-based mechanism. NAMI-A is an anti-metastatic drug, meaning it prevents the spread of a tumour to other parts of the body. Its capacity to prevent metastasis is likely due to its ability to prevent angiogenesis, the establishment of new blood vessels to the tumour, allowing cancer cells to break off from the original tumour and travel through the blood stream to form a new tumour. In vivo studies showed that NAMI-A prevents the signalling required for angiogenesis. It has not been shown to induce cell death or apoptosis. ${ }^{31}$ Further work on mice lung tumours showed that NAMI-A had no effect on the tumours themselves but prevented metastatic behaviour. ${ }^{32}$ 

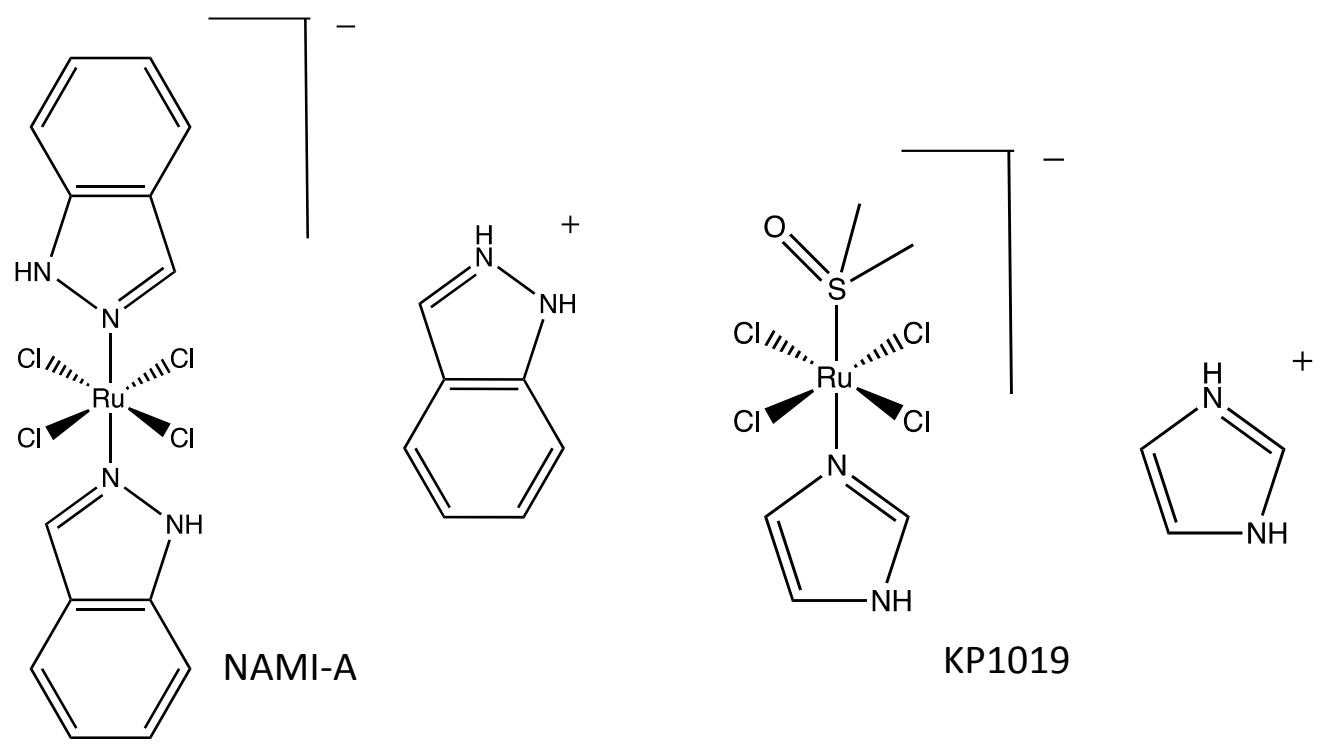

Figure 2: NAMI-A and KP1019

The in vitro studies by Marian et al. on colorectal cancer cell lines showed KP1019 is cytotoxic because it causes oxidative stress in the cells by producing $\mathrm{H}_{2} \mathrm{O}_{2}$. It also promotes apoptosis. Among the causes of this apoptosis is the depolarisation of the mitochondrial membrane. ${ }^{33}$ In further research, some damage to DNA via breaks in the DNA strands was also reported. ${ }^{34}$ This was discovered using gel electrophoresis but the mechanism behind the DNA damage is unknown and it appears to be secondary in cytotoxicity to the well known apoptosis inducing behaviour of KP1019. ${ }^{34}$

\section{Topoisomerase Inhibition}

Topoisomerases are a class of enzymes which remove tension, supercoiling and tangles from DNA. ${ }^{35}$ Disabling topoisomerases in cancer cells would result in DNA not being replicated and transcribed as required, interfering with tumorous tissue. The first proof of a ruthenium complex interfering with a topoisomerase enzyme was in 1999 when Kondapi et al. discovered $\left[\mathrm{RuCl}_{2}\left(\mathrm{C}_{6} \mathrm{H}_{6}\right)(\mathrm{dmso})\right]$ binds to topoisomerase II, preventing it from functioning. 36 


\section{Reduction of $\mathrm{Ru}(\mathrm{III})$ to $\mathrm{Ru}(\mathrm{II})$}

Although this project was focussed on the synthesis of arene $\mathrm{Ru}(\mathrm{II})$ complexes, it is worthwhile to discuss the commonly appearing subject of non toxic $\mathrm{Ru}$ (III) complexes being reduced into cytotoxic $\mathrm{Ru}(\mathrm{II})$ complexes at the site of a tumour.

This hypothesised phenomena, referred to in the literature as 'activation by reduction', is grounded on tumorous tissue having a lower $\mathrm{pH}$ than healthy tissue. ${ }^{37}$ The acidic conditions of a tumour are provided by the way in which cellular respiration differs in solid tumours compared with healthy cells. Solid cancerous tumours are made up of densely packed cells. As a result of this, many of the cells do not receive enough oxygen from their network of blood vessels. The cells therefore rely on glycolysis (the first stage of cellular respiration) which does not require as much oxygen. ${ }^{38}$ Pyruvic acid is produced by glycolysis and is believed to be a reducing agent for $\mathrm{Ru}(\mathrm{III})$ complexes.

If this hypothesis were correct there would be an aspect of selectivity induced on the drug delivery system where the $\mathrm{Ru}(\mathrm{III})$ drug would only be reduced into its toxic $\mathrm{Ru}$ (II) form upon arrival at tumours. Therefore, healthy tissue would not be damaged by the presence of the $\mathrm{Ru}(\mathrm{III})$ form of the drug in the body. This would provide a huge advantage over platin prodrugs which change into their active form upon entering any cell, cancerous or not. Although this theory is readily quoted throughout most review articles which emphasise and advertise the potential of $\mathrm{Ru}$ (III) complexes as anti-tumour agents, the evidence is not so convincing. There have been no in vivo studies that have provided definite evidence of activation by reduction occurring. ${ }^{37}$ Also in general chemistry, acidic environments are usually oxidising, such as in the case of the reaction of a metal and an acid to produce $\mathrm{H}_{2}$ and a metal salt. 
The aforementioned drug NAMI-A, currently trialled for treating lung cancer, is a $\mathrm{Ru}(\mathrm{III})$ complex. The lungs have a superfluous supply of oxygen. Therefore, the cancerous cells in a lung tumour will not rely on glycolysis to meet energy requirements, so no acidic conditions would be introduced to the environment around the lungs. NAMI-A would therefore not be reduced by pyruvic acid and its activity as an anti-tumour agent occurs without reduction. 37, 39 Furthermore, an in vitro study by Sava et al. on NAMI-A found that reduction to the +2 oxidation state readily occurs without a low $\mathrm{pH}$. Also, contrary to what was expected their in vivo experiment, using NAMI-A in mice with mammary carcinoma, showed that the use of glutathione as a reducing agent actually made NAMI-A less cytotoxic to cancer cells. ${ }^{40}$

If activation by reduction was a necessary component for ruthenium chemotherapeutics, there would not be the developing field of cytotoxic organometallic $\mathrm{Ru}(\mathrm{II})$ complexes which do not require activation by reduction. ${ }^{37,41}$

\section{Ruthenium complexes}

Ruthenium complexes in the +2 and +3 oxidation states are the most stable under biological conditions. ${ }^{7}$ The geometries of these complexes are generally octahedral. This means that the complex has additional axial ligands compared to that of square-planar Cisplatin. This could mean interaction of a ruthenium complex with DNA could be more hindered and thus less favourable, compared to that of Cisplatin with DNA. ${ }^{28}$ However, it could also allow for new modes of DNA interaction. ${ }^{41}$ This could enable ruthenium complexes to be cytotoxic against Cisplatin resistant cells. Furthermore, the presence of additional ligands allows for the more precise adjustment of steric and electronic properties of the ruthenium complex. ${ }^{7}$ 


\section{Organometallic Ruthenium Complexes (Ru(II))}

The term "bioorganometallic chemistry" was coined to describe the field of organometallic compounds that possess a potential for medicinal applications. ${ }^{42}$ Organometallic complexes are suggested as possible anticancer agents because they have properties associated with both organic molecules (comparable to those in the body) and inorganic complexes shown to have anti-cancer effects. ${ }^{43}$ Bioorganometallics were first investigated for chemotherapeutic properties by Köpf-Maier in 1999, whilst studying the effects of titanocene dichloride on human kidney cancerous cells. Antitumour behaviour was observed. ${ }^{44}$

The main organometallic ruthenium structures studied are half sandwich metallocene complexes with a pi-bonded arene ligand. The ruthenium centre exists in a +2 oxidation state. Interest in studying these compounds is owing to biological compatibility from their amphiphilic structure; the arene functionality is hydrophobic and the ruthenium metal atom is hydrophilic. ${ }^{7}$ The presence of the arene stabilises the ruthenium complex in the +2 oxidation state, preventing oxidation to a $\mathrm{Ru}(\mathrm{III})$ complex. ${ }^{45}$

The work of Sheldrick et al. showed that the ruthenium arene $\left[\mathrm{Ru}\left(\mathrm{n}^{6-}\right.\right.$ $\left.\left.\mathrm{C}_{6} \mathrm{H}_{6}\right)\left(\mathrm{D}_{2} \mathrm{O}\right)_{3}\right]^{2+}$ can bind to guanine bases. ${ }^{46}$ This inspired a large shift in research towards $\mathrm{Ru}(\mathrm{II})$ complexes from $\mathrm{Ru}(\mathrm{III})$, which had typically shown no or little DNA interaction.

Altering the type of arene, chelating group and leaving groups can change the way in which the compound interacts with a biological system. ${ }^{47}$ The ligands attached to the ruthenium can be changed in attempt to increase the anti-cancer potential of the synthesised complexes, such as the incorporation of kinase inhibitors, stopping phosphorylation, or imidazole, which interferes with DNA. 48 


\section{RAED compounds}

Ruthenium arene ethylenediamine (RAED) complexes are a subset of $\mathrm{Ru}(\mathrm{II})$ compounds that are being investigated for potential anti-tumoural properties. RAED complexes have been shown to interact with DNA through the arene moiety. This happens through both hydrophobic and van der Waals interactions with the DNA bases. ${ }^{49}$ More specific research found that the arene group interacts with the guanine of DNA at the N7 position and also thymine at the N3 position (see Figure 3). ${ }^{50}$ Also, the amine groups on the ethylenediamine ligand hydrogen bond with the carbonyl group on guanine. ${ }^{47,49}$ This provides specificity in binding to guanine as thymidine is only a monocyclic structure so hydrogen bonding to the carboxyl group close to the N3 position is not favourable. 51

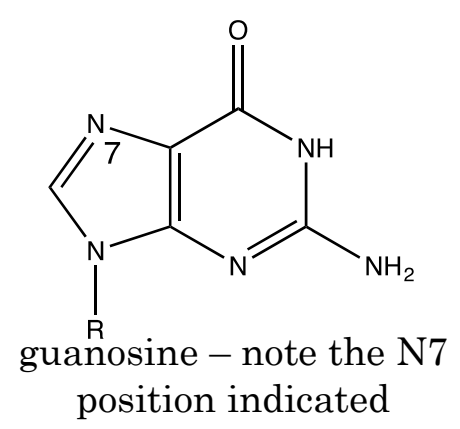

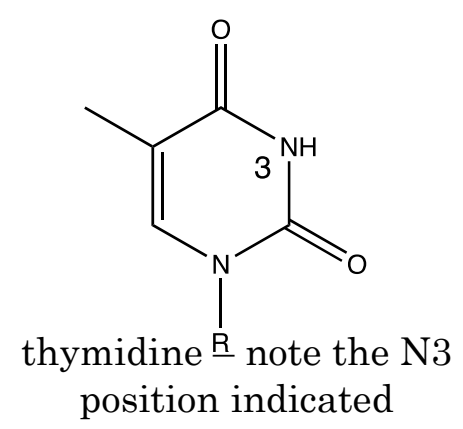

position indicated

Figure 3: Guanosine and Thymidine

The drug RM175 (Figure 4) is a RAED compound. The incorporation of the bicyclic arene is hypothesised to be the cause of the complex being more destructive to DNA compared with the monocyclic arene complexes studied. 49,52 


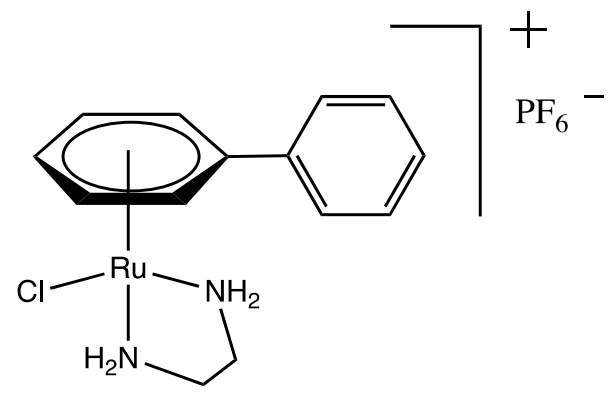

Figure 4: RM175

\section{B-carboline compounds}

Ruthenium (II) complexes have been synthesised using the $b$-carboline ligands (Figure 5). These ligands coordinate to ruthenium via the two nitrogen atoms, just like the binding in RAED compounds. Anti-cancer activity against Cisplatin resistant cells was observed for $b$-carboline compounds. This is thought to be due to the ligand influenced prevention of cyclic dependent kinases - proteins which control the cell cycle. ${ }^{53}$<smiles>c1ccc(-c2nccc3c2[nH]c2ccccc23)nc1</smiles><smiles>c1ccc2c(c1)[nH]c1c(-c3ncc[nH]3)nccc12</smiles><smiles>c1ccc2nc(-c3nccc4c3[nH]c3ccccc34)ccc2c1</smiles>

Figure 5: 6-carboline ligands 


\section{RAPTA compounds}

Following on from the chelated complexes are the air stable RAPTA compounds. The name RAPTA is an abbreviation from having a 'ruthenium' metal centre bound to an $n^{6-} \mathrm{C}_{6} \mathrm{H}_{6}$ 'arene' and a 'PTA' (1,3,5-triaza-7phosphatricyclo-[3.3.1.1]decane) ligand. PTA is used as a ligand due to its hydrophilicity. ${ }^{43}$ In order to be useful as a chemotherapeutic, a ligand must be soluble in a polar solution. PTA also has less steric bulk compared to other commonly used phosophine ligands. ${ }^{54}$ It is therefore unlikely to hinder the reactivity of the complex.

RAPTA compounds have been shown to have anti-metastatic properties similar to NAMI-A. The exact mechanism for the observed anti-metastatic behaviour has not yet been discovered. ${ }^{55}$ However, it is thought that RAPTA compounds have the capacity to bind to proteins involved in the cancer metastasis. Biological studies have concentrated on RAPTA-C and RAPTA$\mathrm{T}$ (Figure 6). RAPTA-C has the arene group paracymene and is currently in phase two clinical trials. RAPTA-T has a toluene arene group. ${ }^{56}$

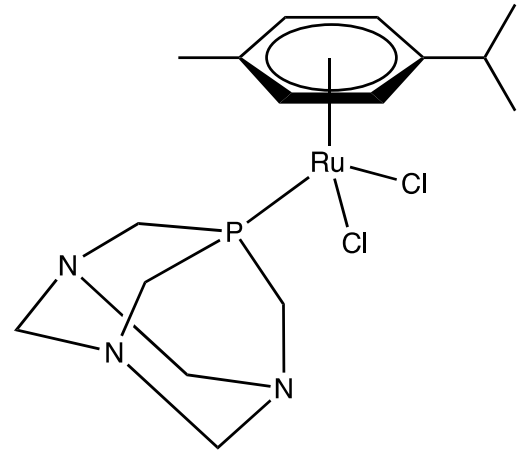

RAPTA-C

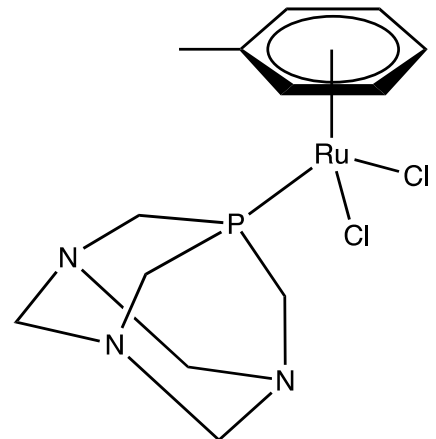

RAPTA-T

Figure 6: RAPTA compounds 
The PTA group in RAPTA complexes is thought to be protonated in low $\mathrm{pH}$ conditions, such as those found in tumorous tissues. The protonated PTA is thought to be DNA damaging. Studies performed on RAPTA-C showed that DNA damage was scarce in non acidic cells. ${ }^{57,} 58$ This makes the drug selectively damaging to cancerous cells and not healthy cells.

\section{RDC11}

Another prospective organometallic ruthenium anti-cancer agent is RDC11 (Figure 7). Studies have shown the level of induced damage on DNA is minor in comparison with that of Cisplatin. From this it can be inferred that the in vivo success of the complex can be attributed to some other mode of action. It is thought RDC11 interacts with DNA, promoting the expression of genes involved in the induction of apoptosis. RDC11 is an anomaly in the trend of ruthenium drugs being designed to undergo ligand exchange, because RDC11 does not undergo ligand substitution. ${ }^{41}$ Notably, this is not a half sandwich structure but has been mentioned in this literature review due to its cytotoxicity and use of nitrogen based ligands.

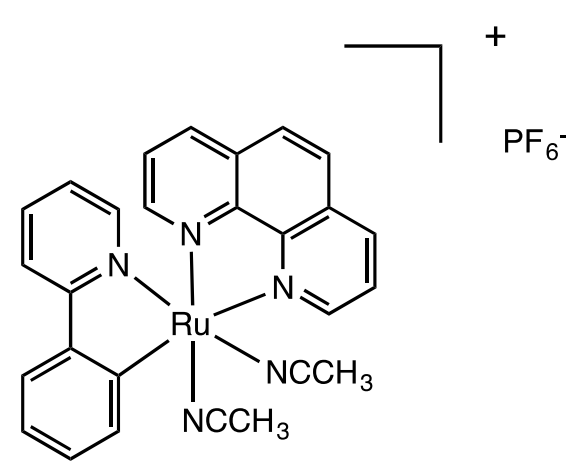

Figure 7:

RDC11 


\section{Heterocyclic ligands}

The work by Somasundaram et al. found that when using bicyclic ligands on an arene half sandwich structure in cells cultures, only the cancerous cells were subjected to the cytotoxic behaviour of the compounds. The ligands used were mercaptobenzothiazole and mercaptobenzoxazole. 59

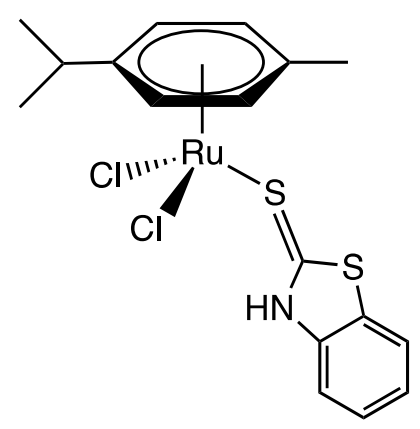

Ligand: mercaptobenzothiazole

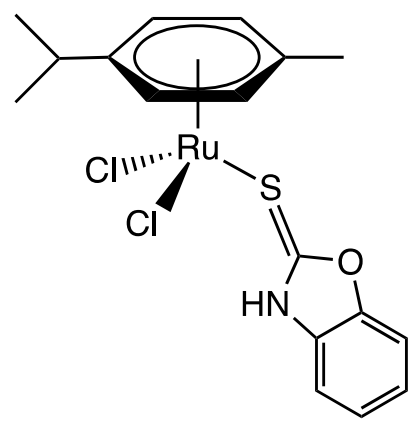

Ligand: mercaptobenzoxazole

Figure 8: ruthenium arene heterocycle compounds

\section{Tethered arene complexes}

A ligand can be tethered to the arene group of a half sandwich structure (Figure 9). These complexes have been studied due to their applications in catalysis. However, the use of an amine tethered to an arene provided opportunity for anti-tumoural properties as groups that could hydrogen bond were predicted to form interstrand crosslinks on DNA. However, only low cytotoxicity occurred during in vitro studies on the new compound (Figure 9).47 


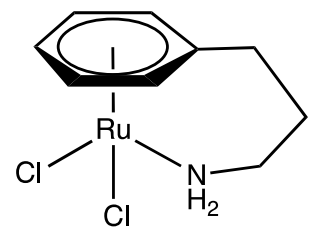

Figure 9: $\left.\eta^{6:} \eta^{1-} \mathrm{C}_{6} \mathrm{H}_{5}\left(\mathrm{CH}_{2}\right)_{3} \mathrm{NH}_{2}\right) \mathrm{RuCl}_{2}$

Prior to this work with amines, Ward et al. synthesised phosphine arene ruthenium complexes (Scheme 1). Firstly, they synthesised their ligand, which consisted of both an arene and a phosphine. They used $\mathrm{RuCl}_{2}$ coordinated to a $p$-cymene group placeholder and reacted this with their ligand. This initially reacts with the phosphine functionality. Then, upon heating or UV exposure, the $p$-cymene group is replaced by the arene group of the ligand ${ }^{60}$. This was the method from which Melchart et al. based their synthesis of $\left.\eta^{6}: \eta^{1-} \mathrm{C}_{6} \mathrm{H}_{5}\left(\mathrm{CH}_{2}\right)_{3} \mathrm{NH}_{2}\right) \mathrm{RuCl}_{2}$ (Figure 9). ${ }_{47}$

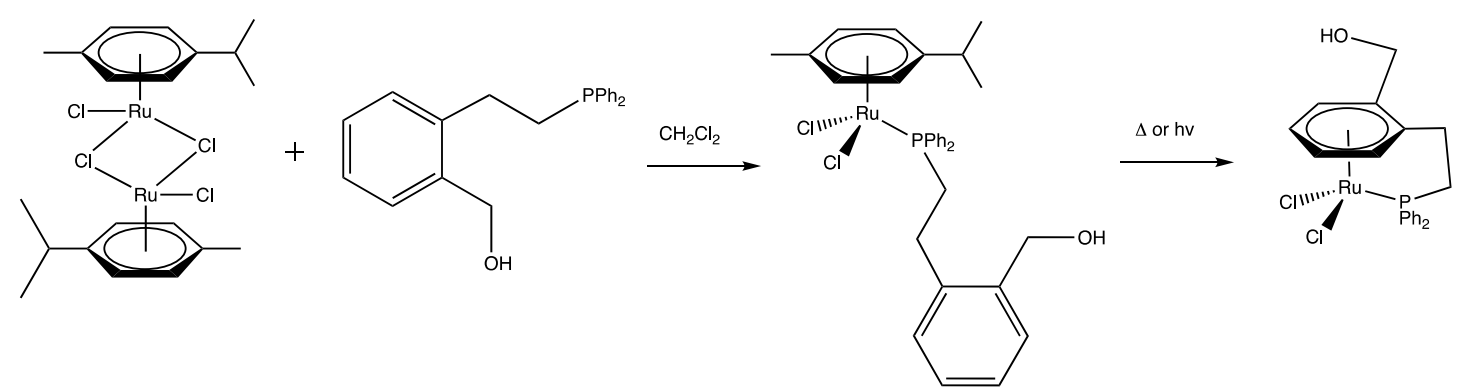

Scheme 1: Synthesis of a phosphine arene ruthenium complex

Alternatively, a method has been used to synthesise a tethered arene ruthenium complex that does not require the replacement of a placeholder arene group. Miyaki et al. synthesised tethered alcohol complexes such as shown in Scheme 2. The carbon chain, which will become the tether, is already on the arene group. This began with the chelation of a nitrogen based ligand, followed by the coordination of the hydroxyl group of the arene to the ruthenium. 61 

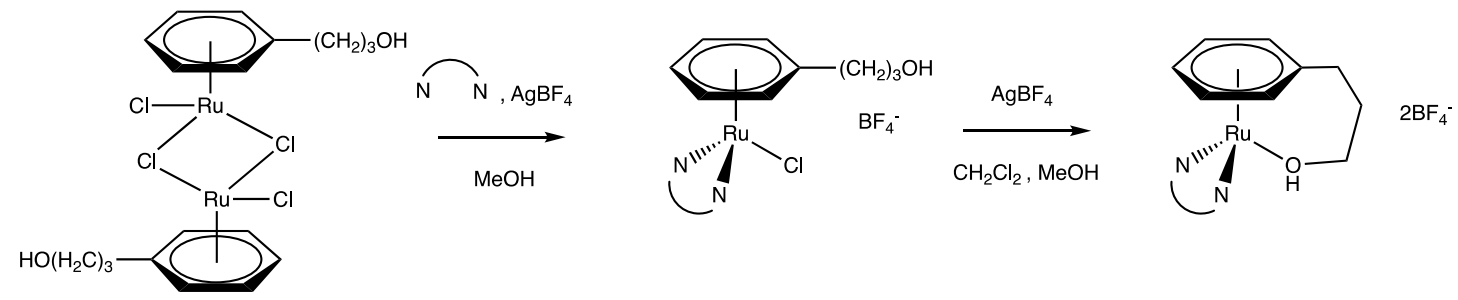

Scheme 2: Synthesis of the first tethered alcohol complex

The tethering of an arene to another ligand is used to stabilise arene ruthenium complexes. Stability of complexes is important because they must withstand physiological conditions and remain in their pro-drug form until inside a target cell.

Most tethered arene ruthenium complexes have a tether from a nitrogen based group. The type of nitrogen based ligand will influence the effectiveness of the complex as an anti-tumoural drug. ${ }^{47}$

\section{Research Aims}

This ligand based research project aimed to establish understanding of arene-hpp ligands to determine if they would be suitable ligands in the synthesis of novel anti-tumour ruthenium complexes. More specifically, the intention was to synthesise half sandwich structures with a $\eta^{6-} \mathrm{C}_{6} \mathrm{H}_{6}$ arene tethered to a guanidine derivative group which is also bound to the metal centre. The long term research goal would be to coordinate these ligands to ruthenium (Figure 10). Guanidine derivatives have an imine functionality. Therefore, in this project an imine functionality was being used instead of the amine functionality used by Sadler et al. ${ }^{47}$ 


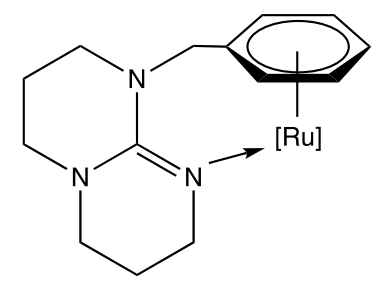

Figure 10: Target compound

Guanidines are known to interact with metal centres. The hpp derivative ligands can be neutral, positively or negatively charged. However, in this project neutral hpp derivative donors were used primarily. ${ }^{62}$

The bicyclic guanidine hppH (1,3,4,6,7,8-hexahydro-2H-pyrimido[1,2a]pyrimidine) (Figure 11) would coordinate through the imine nitrogen to form a stable bond with a metal. ${ }^{63} \mathrm{hppH}$ is also commonly known as TBD (1,5,7-triazabicyclo[4.4.0]dec-5-ene) when the von Baeyer naming convention is applied instead of the IUPAC naming convention. ${ }^{62}$<smiles>C1CN=C2NCCCN2C1</smiles>

Figure 11: hppH

Ruthenium has been shown to interact with hpp guanidine derivatives. Hanan et al. synthesised a range of ruthenium complexes in which they coordinated tridentate ligands to ruthenium. ${ }^{64}$ The coordination took place under microwave irradiation, ethylene glycol and a reducing agent and the complexes were purified by column chromatography. Figure 12 shows an example of one the complexes synthesised using a QpyG (2-hpp- 6quinolylpyridyl) ligand. There is also the $\left(\mathrm{PF}_{6}\right)_{2}$ counterion present in all of these complexes - the ruthenium atom is in the +2 oxidation state. ${ }^{64}$ 


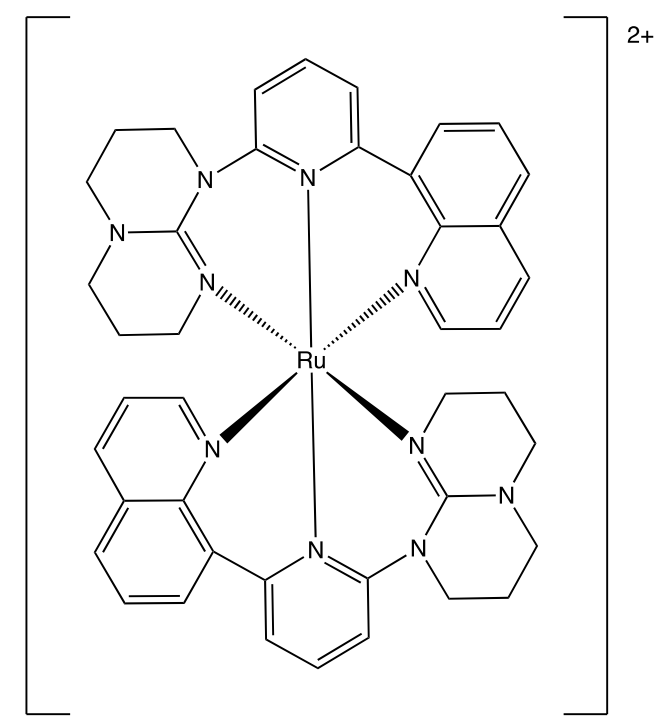

Figure 12: (fac-Ru(QpyG) $\left.)_{2}\right)$

The other functionality that needs to coordinate to the ruthenium is the arene group. Choosing to have an arene group should increase the likelihood of achieving an interaction with DNA. 50 Therefore, the complexes formed may have cytotoxic capabilities, which may be targeted towards tumours by exploiting the transferrin iron uptake pathway. ${ }^{24}$ The use of a tether from the arene to the guanidine should increase the complex stability, compared to a $\mathrm{Ru}$ (II) complex bound to an untethered arene and guanidine separately. ${ }^{47}$ The guanidine ligands may also have an effect in that they allow for apoptotic induction in cancer cells similar to that of RDC11. 


\section{Results and Discussion}

\section{Chapter Two}

\section{Arene-hpp Ligands}

\section{Introduction}

This chapter outlines the preliminary coordination chemistry carried out during this research project using ligands that consist of both an arene group capable of $\pi$ donation and at least one hpp group capable of $\sigma$ donation. This chapter is in five sections, one for each of the five arene-hpp ligands synthesised and subsequent coordination attempts and successes.

Section One: Coordination Attempts using the $\mathrm{Ph}\left(\mathrm{CH}_{2} \mathrm{hpp}\right)$ Ligand<smiles>c1ccc(CN2CCCN3CCCN=C32)cc1</smiles>

Figure 13: $\mathrm{Ph}\left(\mathrm{CH}_{2} \mathrm{hpp}\right)$ 
Synthesis and Characterisation of the $\mathrm{Ph}\left(\mathrm{CH}_{2} \mathrm{hpp}\right)$ Ligand (Compound 1)

Before attempts at coordination chemistry could occur, compound 1 $\mathrm{Ph}\left(\mathrm{CH}_{2} \mathrm{hpp}\right)$ (Figure 13) was synthesised (Scheme 3). The synthesis was conducted in THF via the deprotonation of hppH with $\mathrm{NaH}$ and subsequent addition of benzyl bromide. The THF was removed in vacuo and the ensuing mixture was redissolved in toluene. The $\mathrm{NaBr}$ by-product is not soluble in toluene so can be removed by filtration. The volatiles were removed from the resultant clear yellow solution. Compound 1 has been synthesised prior to this project. 65 The synthetic method previously reported was closely followed with minor changes to optimise yield and purity. As evidence of incomplete deprotonation of hppH (via ${ }^{1} \mathrm{H}$ NMR) was found in early attempts of this synthesis, potassium tert-butoxide $(\mathrm{K} t \mathrm{BuO})$ was employed as a catalyst during the deprotonation step of the synthesis in conjunction with the use of freshly purchased $\mathrm{NaH}(95 \%)$ as opposed to the pre-existing $\mathrm{NaH}(60 \%)$ in mineral oil.
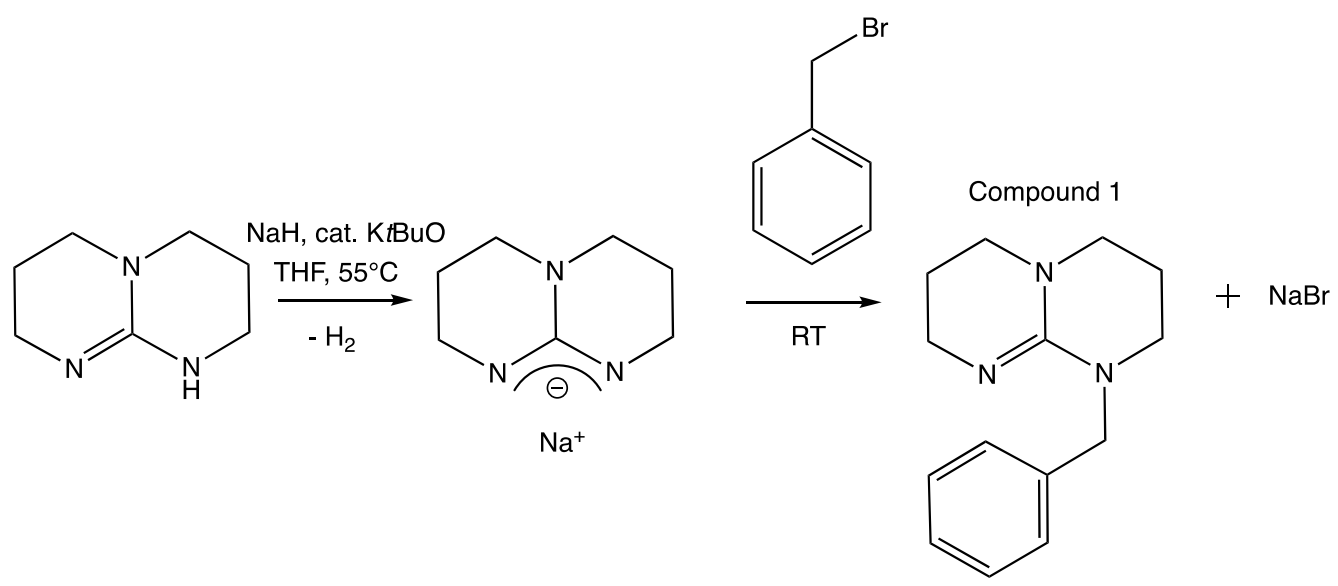

Scheme 3: Synthesis of $\mathrm{Ph}\left(\mathrm{CH}_{2} \mathrm{hpp}\right)$

Although this ligand has been previously synthesised and characterised, a discussion of the ${ }^{1} \mathrm{H}$ NMR spectrum of 1 in $\mathrm{C}_{6} \mathrm{D}_{6}$ is included as this is used as a reference for understanding the coordination of $\mathrm{Ph}\left(\mathrm{CH}_{2} \mathrm{hpp}\right)$ to metals during coordination attempts. 
The downfield section of the ${ }^{1} \mathrm{H}$ NMR spectrum is home to the aromatic resonances of the $\mathrm{Ph}\left(\mathrm{CH}_{2} \mathrm{hpp}\right)$ ligand which belong to the arene ring. The doublet at $7.41 \mathrm{ppm}$ is assigned to the ortho protons of the ring. The multiplet at $7.19 \mathrm{ppm}$ is overlapping with the $\mathrm{C}_{6} \mathrm{D}_{6}$ residual solvent peak (and would otherwise be a triplet) is assigned to the meta position protons of the ring and the triplet at $7.08 \mathrm{ppm}$ is assigned to the para position protons on the ring.

The characteristic methylene peak is referred to frequently throughout this thesis. This is the methylene group which joins the hpp unit to the benzene ring. It is found at $4.84 \mathrm{ppm}$ in $\mathrm{Ph}\left(\mathrm{CH}_{2} \mathrm{hpp}\right)$. This singlet resonance is isolated in its region of the spectrum, so is always easy to identify in a clean spectrum when there is a shift in peaks as it will not overlap with other resonances. For this reason, the methylene peak is used as an integration reference point with an integration of $2 \mathrm{H}$. A shift in this methylene resonance is used as evidence throughout this thesis as an indication of coordination of the ligand to a metal. This is because a coordination of hpp through an imine nitrogen causes electronic changes to the hpp group that will alter the environment of the methylene. Furthermore, the establishment of a $\pi$ donation through the arene group to the metal would also induce a change in the resonance of the methylene peak.

Further upfield from the methylene peak are the hpp protons of $\mathrm{Ph}\left(\mathrm{CH}_{2} \mathrm{hpp}\right)$. There are six peaks for hpp protons made up of multiplet resonance reflecting the axial and equatorial position of neighbouring protons. The pseudo triplets are at $3.62 \mathrm{ppm}$, two overlapping triplets forming a multiplet at $2.71 \mathrm{ppm}$ and a triplet at $2.52 \mathrm{ppm}$. Finally, two pseudo quintets are present at 1.65 and $1.38 \mathrm{ppm}$.

The $\mathrm{Ph}\left(\mathrm{CH}_{2} \mathrm{hpp}\right)$ pre-ligand synthesised was then used for coordination chemistry attempts. This experimentation begun with potassium, lithium 
and sodium $\mathrm{N}\left\{\mathrm{SiMe}_{3}\right\}_{2^{-}}$(hexamethyldisilazane) salts. The research started with $\mathrm{KN}\left\{\mathrm{SiMe}_{3}\right\}_{2}$, as potassium is a large metal which favours $\pi$ interactions. As $\mathrm{Ph}\left(\mathrm{CH}_{2} \mathrm{hpp}\right)$ had never been coordinated to a metal before, it was important to see if the idea of coordinating $\mathrm{Ph}\left(\mathrm{CH}_{2} \mathrm{hpp}\right)$ to a metal was viable before attempting syntheses with more expensive transition metals. Group one $\mathrm{N}\left\{\mathrm{SiMe}_{3}\right\}_{2}{ }^{-}$salts were specifically chosen to circumvent the solubility issues often associated with metal halides. The methyl groups on $\mathrm{N}\left\{\mathrm{SiMe}_{3}\right\}_{2^{-}}$make the metal-N$\left\{\mathrm{SiMe}_{3}\right\}_{2^{-}}$salts more soluble in solvents such as THF and toluene, which are appropriate for use in air and water sensitive chemistry.

\section{Synthesis and Characterisation of $\mathrm{KN}\left\{\mathrm{SiMe}_{3}\right\}_{2} \bullet \mathrm{Ph}\left(\mathrm{CH}_{2} \mathrm{hpp}\right)$ (Compound 2)}

An attempt to coordinate $\mathrm{Ph}\left(\mathrm{CH}_{2} \mathrm{hpp}\right)$ to $\mathrm{KN}\left\{\mathrm{SiMe}_{3}\right\}_{2}$ was conducted by adding a pale yellow toluene solution of the ligand to the colourless $\mathrm{KN}\left\{\mathrm{SiMe}_{3}\right\}_{2}$ toluene solution, in equimolar amounts. The solution turned from yellow to orange. Attempts at crystallisation via slow evaporation of toluene failed, resulting in formation of an amorphous solid. Therefore, crystallisation was re-attempted by redissolving the solid in toluene and leaving in a freezer at $-30^{\circ} \mathrm{C}$. Block like crystals were obtained. However, attempts to mount the crystals for an X-ray diffraction experiment failed with visible bubbling and disintegrating of the crystals in the X-ray oil. This shows that the compound synthesised was very air sensitive and reacted with even the trace amounts of oxygen/water that diffused through the $\mathrm{X}^{-}$ ray oil to the crystals. Attempts to obtain diffraction data on the crystals were therefore unsuccessful. 


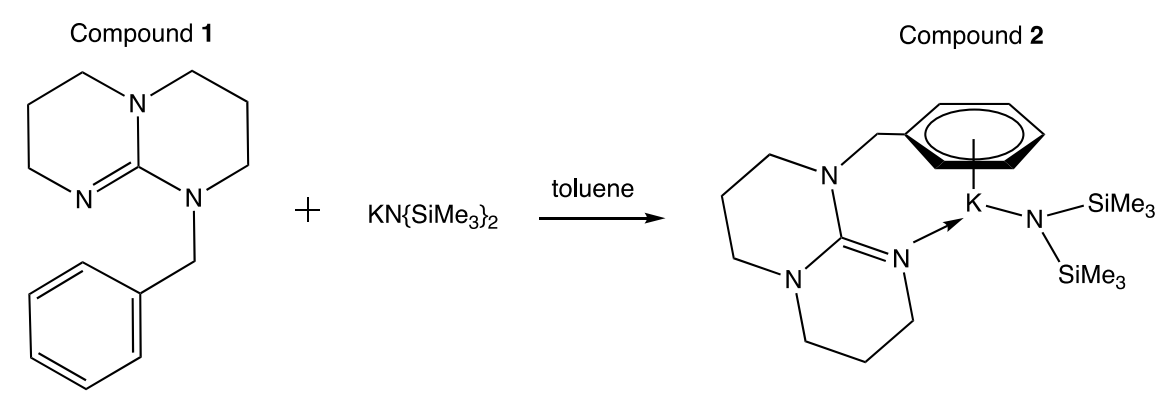

Scheme 4: The synthesis of $\mathrm{KN}\left\{\mathrm{SiMe}_{3}\right\}_{2} \bullet \mathrm{Ph}\left(\mathrm{CH}_{2} \mathrm{hpp}\right)$

(Without a crystal structure bonding mode is not confirmed)

Analysis of the ${ }^{1} \mathrm{H}$ NMR spectrum of the crystals shows that the characteristic methylene peak from the ligand has shifted upfield from 4.84 ppm to $4.73 \mathrm{ppm}$. This is indicative of coordination of the $\mathrm{Ph}\left(\mathrm{CH}_{2} \mathrm{hpp}\right)$ ligand to the potassium metal. The protons of non-complexed $\mathrm{KN}\left\{\mathrm{SiMe}_{3}\right\}_{2}$ have a chemical shift of $0.14 \mathrm{ppm}$ in $\mathrm{C}_{6} \mathrm{D}_{6}$, this resonance has shifted downfield to $0.20 \mathrm{ppm}$ upon the addition of $\mathrm{Ph}\left(\mathrm{CH}_{2} \mathrm{hpp}\right)$.

As no crystal structure was obtained for compound 2, a definitive structure cannot be provided but the NMR data suggests coordination of the ligand may have occurred, which justifies venturing into analogous reactions with other group one metal $\mathrm{N}\left\{\mathrm{SiMe}_{3}\right\}_{2}{ }^{-}$salts. Any crystallographic data obtained for analogous compounds would allow for further insight into the coordination behaviour occurring in 2 .

\section{Synthesis and Characterisation of $\operatorname{LiN}\left\{\mathrm{SiMe}_{3}\right\}_{2} \bullet \mathrm{Ph}\left(\mathrm{CH}_{2} \mathrm{hpp}\right)$ (Compound 3)}

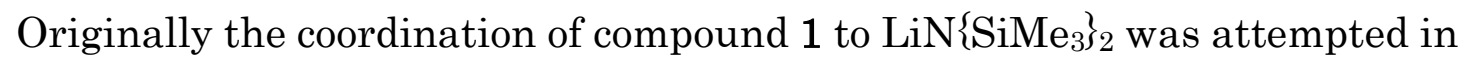
THF. At first, a golden yellow colour appeared which gradually turned into a yellow-brown. The THF was removed in vacuo and the resultant oily product was redissolved in minimal toluene. Recrystallisation by slow evaporation of toluene was attempted but resulted in a brown oil and no noticeable crystalline material. As THF is a coordinating solvent it could 
have been responsible for a product decomposition whereby THF would compete with 1 as a stronger coordinating ligand. The coordination of 1 to $\mathrm{LiN}\left\{\mathrm{SiMe}_{3}\right\}_{2}$ was subsequently reattempted in the non-coordinating solvent toluene (Scheme 5). Needle-like crystals formed when the nearly saturated solution was left in the freezer at $-30^{\circ} \mathrm{C}$ for 16 hours.

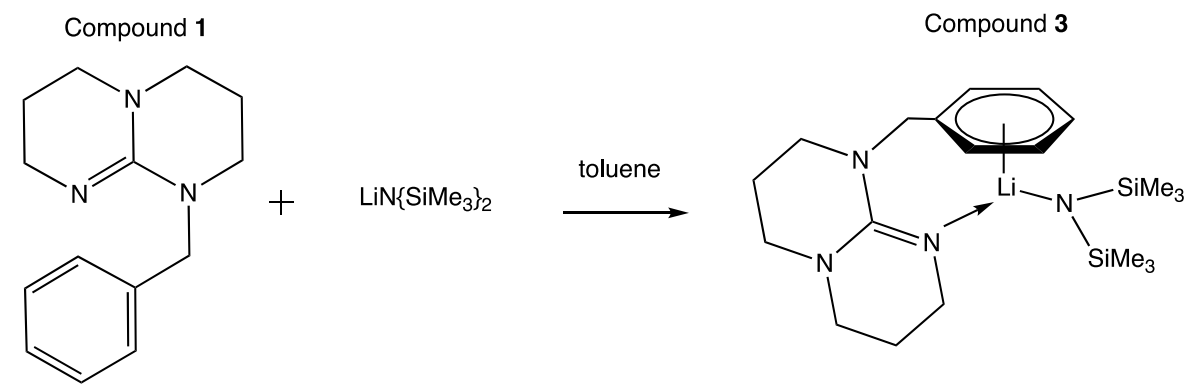

Scheme 5: The synthesis of $\operatorname{LiN}\left\{\mathrm{SiMe}_{3}\right\}_{2} \bullet \mathrm{Ph}\left(\mathrm{CH}_{2} \mathrm{hpp}\right)$

(Without a crystal structure bonding mode is not confirmed)

Both ${ }^{1} \mathrm{H}$ NMR and ${ }^{13} \mathrm{C}$ NMR data were collected for compound 3. Evidence for coordination comes from comparing the ${ }^{1} \mathrm{H}$ NMR spectrum of 3 with that of the uncomplexed $\mathrm{Ph}\left(\mathrm{CH}_{2} \mathrm{hpp}\right)$ ligand. There are slight changes in the aromatic resonances between the $\mathrm{Ph}\left(\mathrm{CH}_{2} \mathrm{hpp}\right)$ ligand and compound 3 indicating a minor change in the environment of the phenyl protons. The doublet resonance assigned to the proton in the para position of the phenyl ring shifted upfield from $7.08 \mathrm{ppm}$ to $7.02 \mathrm{ppm}$. The triplet assigned to the meta position protons also shifted by $0.06 \mathrm{ppm}$ (from $7.19 \mathrm{ppm}$ to $7.13 \mathrm{ppm}$ ). The triplet assigned to the ortho position protons shifted by $0.16 \mathrm{ppm}$ (from $7.41 \mathrm{ppm}$ to $7.25 \mathrm{ppm}$ ). A larger resonance change would be expected with the meta and para position protons if a $\pi$-interaction had been achieved. This is because forming a half sandwich structure with the $\mathrm{LiN}\left\{\mathrm{SiMe}_{3}\right\}_{2}$ would have made a substantial change to the magnetic environment for the aromatic protons.

The other coordination mode hypothesised for the $\mathrm{Ph}\left(\mathrm{CH}_{2} \mathrm{hpp}\right)$ ligand is for a $\sigma$ donation using the lone pair from the available imine nitrogen of the 
hpp group of $\mathrm{Ph}\left(\mathrm{CH}_{2} \mathrm{hpp}\right)$. The upfield shift in the methylene singlet resonance from $4.84 \mathrm{ppm}$ to $4.58 \mathrm{ppm}$ supports that this has occurred with $\mathrm{LiN}\left\{\mathrm{SiMe}_{3}\right\}_{2}$. This is likely due to a through space interaction to the metal, not a through bond interaction. A weak $\pi$ interaction would be expected as the NMR data were collected in $\mathrm{C}_{6} \mathrm{D}_{6}$ which is an aromatic solvent. Figure 14 shows that free rotation exists around the hpp-methylene $\mathrm{N}-\mathrm{C}$ bond which means the structure is fluxional between an aromatic interaction and the methylene protons close to the metal. Further support of coordination is found in the small upfield changes of the resonances assigned to the hpp ring protons.

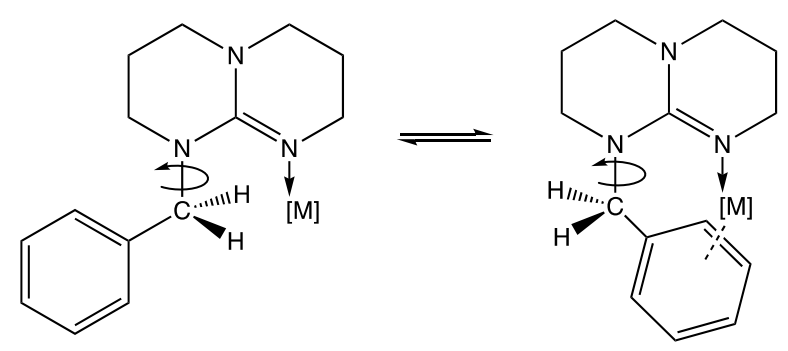

Figure 14: Free rotation around N-C bond causing a fluxional structure in solution

The crystals formed of this compound also disintegrated in the X-ray oil so no crystal structure of compound 3 could be obtained. Therefore, the mode of coordination achieved in this synthesis cannot be ascertained. However, the discussed changes in ${ }^{1} \mathrm{H}$ NMR resonances between the uncomplexed ligand and 3, provided evidence of a $\sigma$ donation (from the hpp group to the lithium metal).

\section{Synthesis and characterisation of $\left(\mathrm{NaN}\left\{\mathrm{SiMe}_{3}\right\}_{2}\right)_{2} \bullet 2\left(\mathrm{Ph}\left(\mathrm{CH}_{2} \mathrm{hpp}\right)\right)$ (Compound 4)}

A solution of compound 1 in toluene was added dropwise to $\mathrm{NaN}\left\{\mathrm{SiMe}_{3}\right\}_{2}$ (Scheme 6). Slow evaporation of the toluene yielded small block shaped crystals of compound 4 . These crystals were isolated in a small amount of 
brown oil but were themselves colourless. Difficulties arose when trying to find a suitable crystal to load on the X-ray diffractometer due to the extreme reactivity of the crystals as mentioned in the syntheses of $\mathbf{2}$ and 3 . However, a crystal was eventually found that allowed for diffraction data to be obtained.

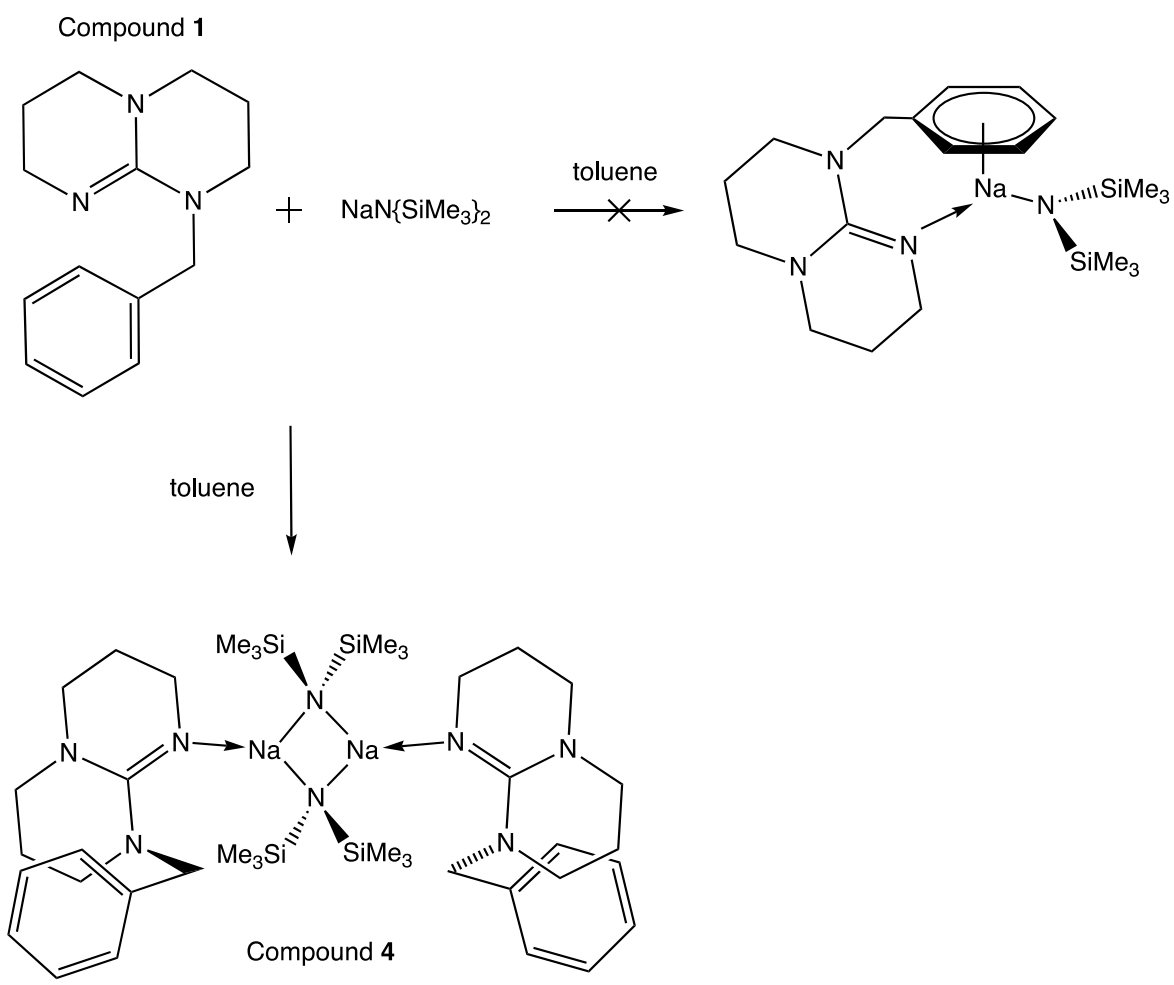

Scheme 6: The attempted synthesis of $\mathrm{NaN}\left\{\mathrm{SiMe}_{3}\right\}_{2} \bullet \mathrm{Ph}\left(\mathrm{CH}_{2} \mathrm{hpp}\right)$ and subsequent synthesis of $\left(\mathrm{NaN}\left\{\mathrm{SiMe}_{3}\right\}_{2}\right)_{2} \bullet 2\left(\mathrm{Ph}\left(\mathrm{CH}_{2} \mathrm{hpp}\right)\right)$

The ${ }^{1} \mathrm{H}$ NMR data collected for compound 4 was similar to that of compounds $\mathbf{2}$ and $\mathbf{3}$ with the same upfield shift compared to the spectrum of the uncomplexed ligand 1 . The resonance for the methylene protons shifted from $4.84 \mathrm{ppm}$ to $4.77 \mathrm{ppm}$. This is only a change of $0.07 \mathrm{ppm}$ as opposed to the $0.11 \mathrm{ppm}$ change seen in 2 and the $0.26 \mathrm{ppm}$ change seen for 3 . The change in phenyl proton resonances is also less pronounced than that of $\mathbf{2}$ and 3 . 
The crystal structure of 4 was obtained (Figure 15). The structure shows $\mathrm{NaN}\left\{\mathrm{SiMe}_{3}\right\}_{2}$ in its dimeric form with two $\mathrm{Ph}\left(\mathrm{CH}_{2} \mathrm{hpp}\right)$ ligands coordinated through the imine nitrogen to sodium.

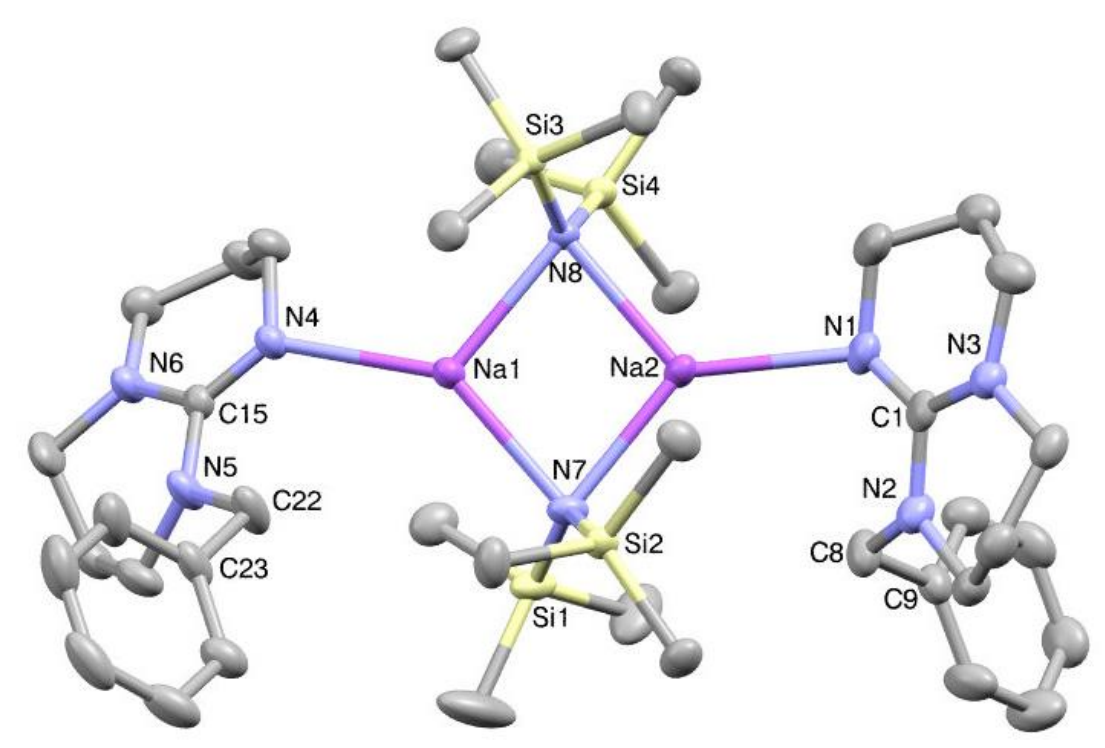

Figure 15: Thermal ellipsoid representation (50\%) of $\left(\mathrm{Na}\left[\mathrm{N}\left\{\mathrm{SiMe}_{3}\right\}_{2}\right)_{2} \bullet 2\left(\mathrm{Ph}\left(\mathrm{CH}_{2} \mathrm{hpp}\right)\right)\right.$. Selected bond lengths and angles have been reported in Tables 1 and 2 respectively. All hydrogen atoms have been omitted for clarity

\begin{tabular}{|c|c|}
\hline Atoms of Bond & Bond Length $(\AA)$ \\
\hline $\mathrm{Na}(1) \mathrm{N}(7)$ & $2.4398(12)$ \\
\hline $\mathrm{Na}(1) \mathrm{N}(8)$ & $2.4155(11)$ \\
\hline $\mathrm{Na}(2) \mathrm{N}(7)$ & $2.4108(12)$ \\
\hline $\mathrm{Na}(2) \mathrm{N}(8)$ & $2.4072(11)$ \\
\hline $\mathrm{Na}(1) \mathrm{N}(4)$ & $2.4270(12)$ \\
\hline $\mathrm{Na}(2) \mathrm{N}(1)$ & $2.4591(13)$ \\
\hline
\end{tabular}

Table 1: Selected bond lengths of compound 4 


\begin{tabular}{|c|c|}
\hline Atoms & Angle $\left(^{\circ}\right)$ \\
\hline $\mathrm{C}(9) \mathrm{C}(8) \mathrm{N}(2)$ & $113.39(12)$ \\
\hline $\mathrm{C}(23) \mathrm{C}(22) \mathrm{N}(5)$ & $111.23(12)$ \\
\hline
\end{tabular}

Table 2: Selected bond angles of compound 4

The structure shows that the phenyl rings of $\mathrm{Ph}\left(\mathrm{CH}_{2} \mathrm{hpp}\right)$ are not close to the sodium metal in 4 . The distance between the sodium atoms and the closest carbon of their nearest aromatic ring (Na1 to $\mathrm{C} 23)$ and (Na2 to $\mathrm{C} 9$ ) are $4.858 \AA$ and $4.763 \AA$ respectively. This distance is too long to allow for any $\pi$-interaction between the aromatic rings of the complexed ligands and the sodium atoms. The positioning of the phenyl groups in the complex is most likely due to the steric bulk of the two [N\{SiMe $\left.\}_{2}\right]-$ groups on the $\mathrm{NaN}\left\{\mathrm{SiMe}_{3}\right\}_{2}$ dimer.

From Figure 15 it can be observed that the $\mathrm{Ph}\left(\mathrm{CH}_{2} \mathrm{hpp}\right)$ ligand on the left of the structure has a phenyl group in front of the hpp group and the $\mathrm{Ph}\left(\mathrm{CH}_{2} \mathrm{hpp}\right)$ ligand on the right has a phenyl group behind the hpp group.

The successful coordination of $\mathrm{Ph}\left(\mathrm{CH}_{2} \mathrm{hpp}\right)$ to sodium and the corresponding crystal structure obtained can provide insight into what happened with compounds $\mathbf{2}$ and $\mathbf{3}$. As the NMR data of compounds $\mathbf{2}$ and $\mathbf{3}$ showed similar trends, the complexation of $\mathrm{Ph}\left(\mathrm{CH}_{2} \mathrm{hpp}\right)$ to $\mathrm{KN}\left\{\mathrm{SiMe}_{3}\right\}_{2}$ and $\left.\mathrm{LiN}_{2 \mathrm{SiMe}}\right\}_{2}$ most likely occurred. However, without a crystal structure it cannot be determined whether 2 and 3 were comprised of a $\mathrm{KN}\left\{\mathrm{SiMe}_{3}\right\}_{2} / \mathrm{LiN}\left\{\mathrm{SiMe}_{3}\right\}_{2}$ monomer and single $\mathrm{Ph}\left(\mathrm{CH}_{2} \mathrm{hpp}\right)$ ligand or a $\mathrm{KN}\left\{\mathrm{SiMe}_{3}\right\}_{2} / \mathrm{LiN}\left\{\mathrm{SiMe}_{3}\right\}_{2}$ dimer and two $\mathrm{Ph}\left(\mathrm{CH}_{2} \mathrm{hpp}\right)$ ligands. 
Currently in the literature, there are only three crystal structures which have a $\mathrm{NaN}\left\{\mathrm{SiMe}_{3}\right\}_{2}$ dimer to which a ligand is coordinating to each sodium atom through a nitrogen donor (Figure 16) This highlights how unusual this type of structure is. All three of these known structures have a nitrogen donor which has a triple bond to a carbon atom. ${ }^{66,67}$ The mean distances between sodium and the coordinating nitrogen atoms in the two structures by Lappert et al. are $2.378 \AA$ and $2.403 \AA .67$ This is slightly shorter than the equivalent bond average of $2.4431 \AA$ in 4 .

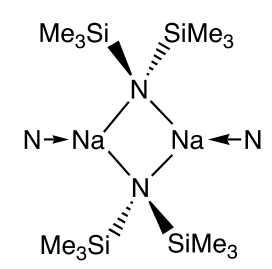

Figure 16: Two ligands coordinating to dimeric $\mathrm{NaN}\left\{\mathrm{SiMe}_{3}\right\}_{2}$ through a nitrogen donor

\section{Second Generation arene-hpp Ligands}

The results from the use of $\mathrm{Ph}\left(\mathrm{CH}_{2} \mathrm{hpp}\right)$ in section one, led to the progression of the project to include more complicated ligands containing multiple hpp groups that differ in their substitution arrangement around the aromatic ring. As hpp imine nitrogen donors have been shown to coordinate to metal centres, ligands with two or three hpp groups can be used to investigate the coordination of arene-hpp ligands which are bidentate or tridentate, respectively. If more than one hpp group is coordinating to a metal centre, the aromatic ring which joins them may be forced into close enough proximity to the metal centre to allow for the $\pi$-interaction that could not be achieved with the $\mathrm{Ph}\left(\mathrm{CH}_{2} \mathrm{hpp}\right)$ ligand which only had one hpp group. Compounds 5, 6, and 7 (Figure 17) are the 1,2 1,3 and 1,4 substitutions of $\mathrm{CH}_{2}$ hpp groups around the phenyl ring, respectively. Compound 8 has a $1,3,5$ substitution around the phenyl ring and has the potential to be used 
as a tridentate ligand. There is a methylene group connecting each hpp group to the phenyl ring as with $\mathrm{Ph}\left(\mathrm{CH}_{2} \mathrm{hpp}\right)$.

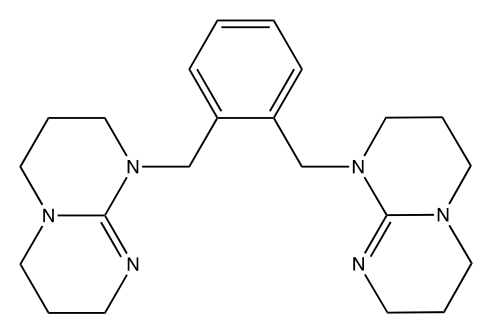

Compound 5

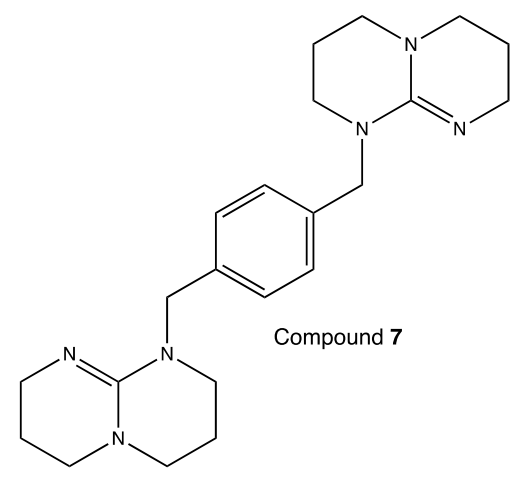<smiles>c1cc(CN2CCCN3CCCN=C32)cc(CN2CCCN3CCCN=C32)c1</smiles>

Compound 6

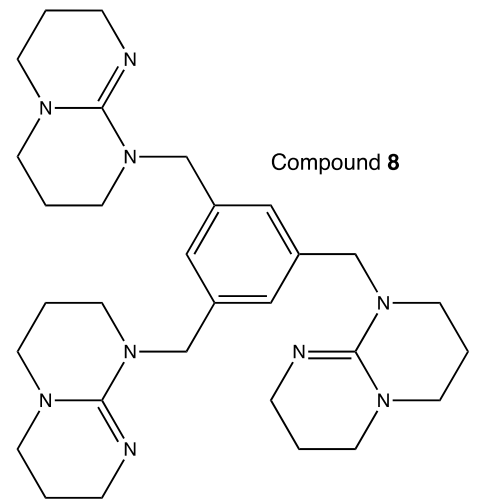

Figure 17: Compound $5: 1,2-\left(\mathrm{CH}_{2} \mathrm{hpp}\right)_{2}{ }^{-} \mathrm{C}_{6} \mathrm{H}_{4}$, Compound $6: 1,3^{-}$ $\left(\mathrm{CH}_{2} \mathrm{hpp}\right)_{2}-\mathrm{C}_{6} \mathrm{H}_{4}$, Compound $7: 1,4-\left(\mathrm{CH}_{2} \mathrm{hpp}\right)_{2}-\mathrm{C}_{6} \mathrm{H}_{4}$, Compound 8 : $1,3,5-\left(\mathrm{CH}_{2} \mathrm{hpp}\right)_{3}-\mathrm{C}_{6} \mathrm{H}_{3}$

\section{Section Two: Coordination Attempts using the 1,2-( $\left.\mathrm{CH}_{2} \mathrm{hpp}\right)_{2^{-}}$ $\mathrm{C}_{6} \mathrm{H}_{4}$ Ligand}

\section{Synthesis of $1,2-\left(\mathrm{CH}_{2} \mathrm{hpp}\right)_{2}-\mathrm{C}_{6} \mathrm{H}_{4}$ (Compound 5)}

The synthesis of 1,2-( $\left(\mathrm{CH}_{2} \mathrm{hpp}\right)_{2}-\mathrm{C}_{6} \mathrm{H}_{4}$ was based on a previously reported synthesis ${ }^{65}$ and was an analogous synthesis to that of $\mathrm{Ph}\left(\mathrm{CH}_{2} \mathrm{hpp}\right)$ with the same minor changes and the use of $\alpha, \alpha^{\prime}$-dibromo- $\sigma^{-}$-xylene (a 1,2 substituted bromide reagent) (Scheme 7). 


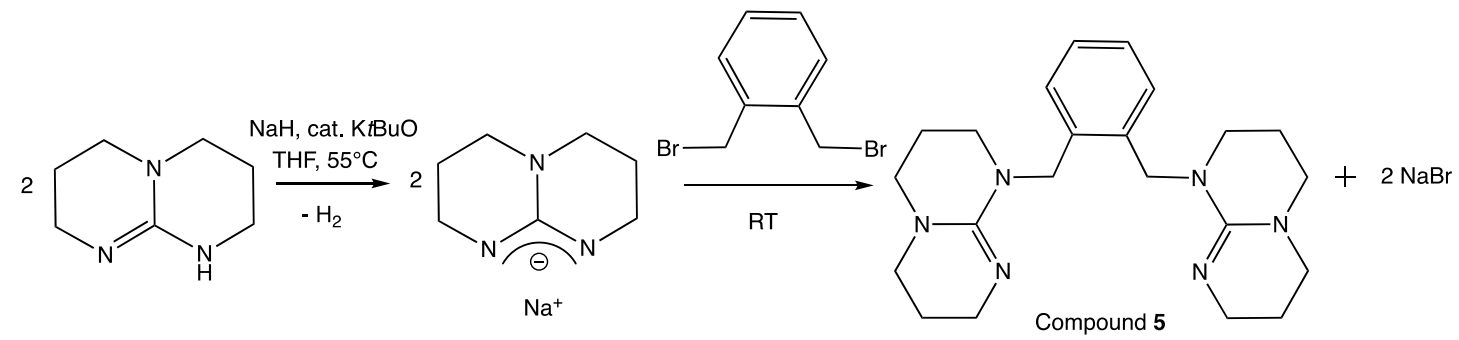

Scheme 7: Synthesis of 1,2-( $\left.\mathrm{CH}_{2} \mathrm{hpp}\right)_{2}-\mathrm{C}_{6} \mathrm{H}_{4}$

\section{Synthesis and Characterisation of $\mathrm{LiN}\left\{\mathrm{SiMe}_{3}\right\}_{2} \bullet 1,2-\left(\mathrm{CH}_{2} \mathrm{hpp}\right)_{2}-\mathrm{C}_{6} \mathrm{H}_{4}$ (Compound 9)}

An NMR scale attempt was conducted for the coordination of $1,2-\left(\mathrm{CH}_{2} \mathrm{hpp}\right)_{2}$ $\mathrm{C}_{6} \mathrm{H}_{4}$ to $\mathrm{LiN}\left\{\mathrm{SiMe}_{3}\right\}_{2}$ (Scheme 8). A solution of $1,2-\left(\mathrm{CH}_{2} \mathrm{hpp}\right)_{2}-\mathrm{C}_{6} \mathrm{H}_{4}$ was added to an equimolar amount of $\mathrm{LiN}\left\{\mathrm{SiMe}_{3}\right\}_{2}$. No crystallisation occurred in the NMR tube so the $\mathrm{C}_{6} \mathrm{D}_{6}$ was removed by evaporation in vacuo. The compound was redissolved in toluene in an unsuccessful crystallisation attempt. ${ }^{1} \mathrm{H}-\mathrm{NMR}$ data was obtained for a dried aliquot of the resultant yellow solution.

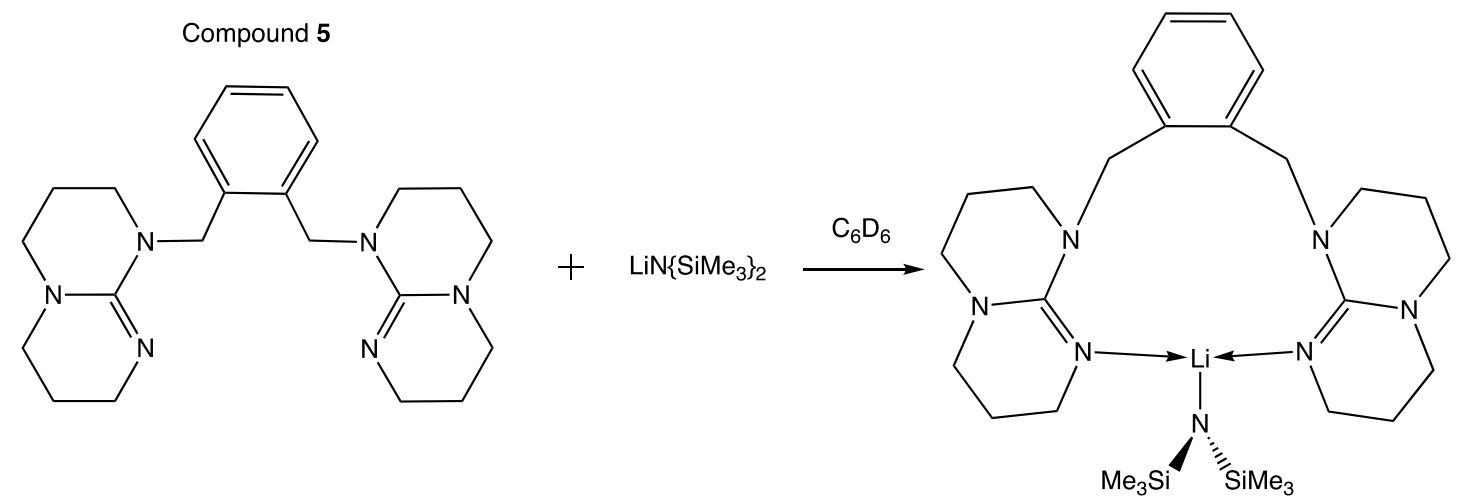

Scheme 8: Synthesis of $\operatorname{LiN}\left\{\mathrm{SiMe}_{3}\right\}_{2} \bullet 1,2-\left(\mathrm{CH}_{2} \mathrm{hpp}\right)_{2}-\mathrm{C}_{6} \mathrm{H}_{4}$

(Without a crystal structure bonding mode is not confirmed) 
In uncomplexed $\mathrm{LiN}\left\{\mathrm{SiMe}_{3}\right\}_{2}$, the ${ }^{1} \mathrm{H}$ NMR resonance is at $0.15 \mathrm{pp}$ in $\mathrm{C}_{6} \mathrm{D}_{6}$. An upfield shift in the resonances assigned to ligand protons occurred upon the addition to $\mathrm{LiN}\left\{\mathrm{SiMe}_{3}\right\}_{2}$. A single methylene peak is present in the spectrum which has shifted from $5.05 \mathrm{ppm}$ in the uncomplexed ligand to $4.79 \mathrm{ppm}$ in compound 9, still with an integration of $4 \mathrm{H}$ suggesting any coordination which has occurred has done so in either a symmetrical manner, using both hpp groups of the ligand or a rapid fluxional process. The ${ }^{1} \mathrm{H}-\mathrm{NMR}$ of compound 9 reveals two peaks for the $\mathrm{LiN}\left\{\mathrm{SiMe}_{3}\right\}_{2}$ methyl protons. The largest, a peak with an integration of $15 \mathrm{H}$, occurs at $0.52 \mathrm{ppm}$ and a peak with an integration of $3 \mathrm{H}$ appears at $0.12 \mathrm{ppm}$ (Figure 18) (Note: the resonance at $0.28 \mathrm{ppm}$ is a silicone grease impurity). This 5:1 ratio of $\mathrm{N}\left\{\mathrm{SiMe}_{3}\right\}_{2}-$ protons implies that one of the six methyl groups is in a different environment. This could be a result of the short $\mathrm{Li}-\mathrm{N}$ bond (due to the small size of the $\mathrm{Li}^{+}$ion) between lithium and the [N\{SiMe$\left.\}_{2}\right]-$ meaning one methyl group is interacting with the aromatic ring of the ligand so N-Si bond is no longer able to rotate freely (Figure 19). Given the ratios of the ${ }^{1} \mathrm{H}$ NMR peaks, only one of the two $\mathrm{SiMe}_{3}$ groups has restricted rotation. The other N-Si bond of [N\{SiMe $\left.\}_{2}\right]-$ is able to freely rotate. 


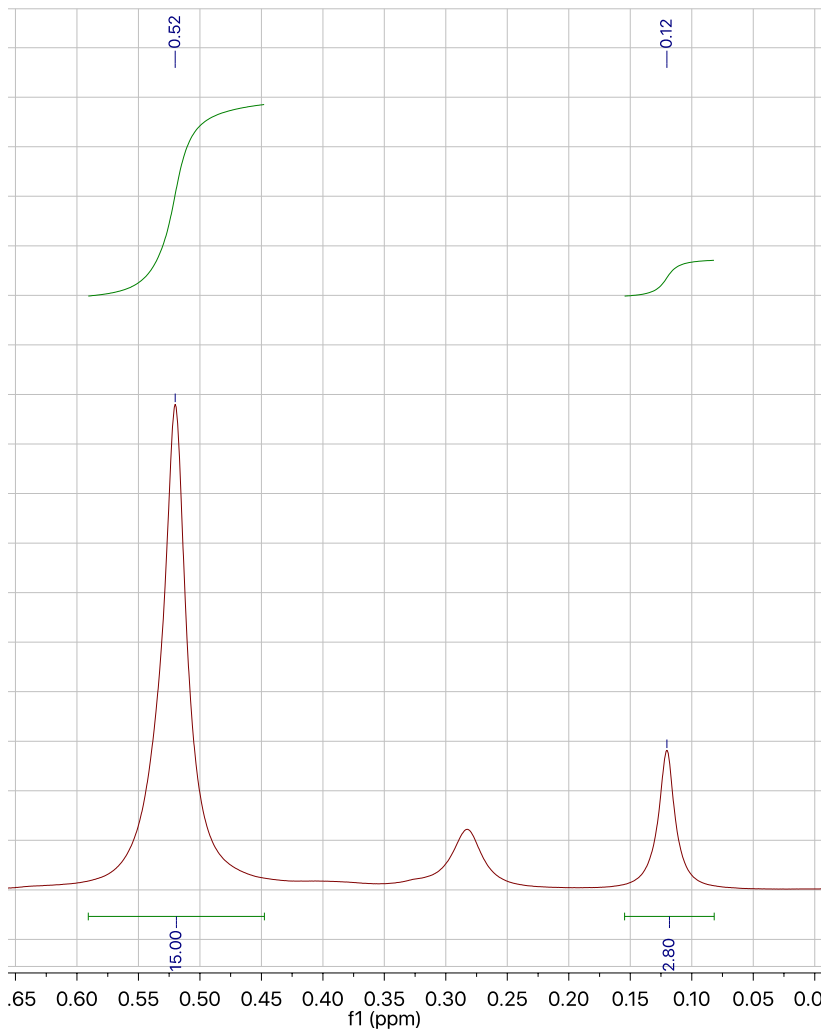

Figure 18: Section of the ${ }^{1} \mathrm{H}$ NMR spectrum of compound 9 illustrating the 5:1 integration ratio of resonances in the $\mathrm{N}\left\{\mathrm{SiMe}_{3}\right\}_{2}-$ region of the spectrum

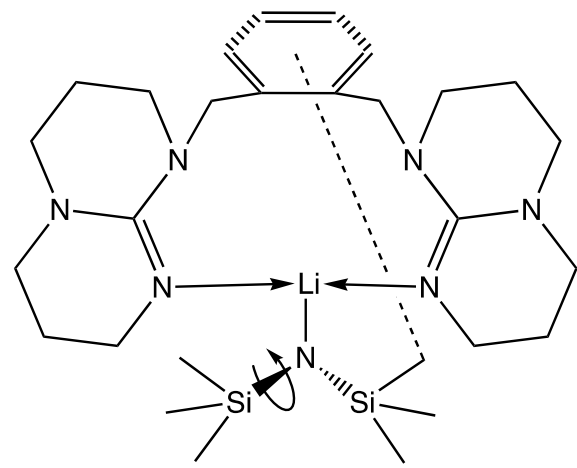

Figure 19: A methyl group of $\left.\mathrm{N}^{2} \mathrm{SiMe}_{3}\right\}_{2}-$ interacting with the arene ring of $1,2-\left(\mathrm{CH}_{2} \mathrm{hpp}\right)_{2}-\mathrm{C}_{6} \mathrm{H}_{4}$ 


\section{Synthesis and Characterisation of $\mathrm{NaN}\left\{\mathrm{SiMe}_{3}\right\}_{2} \bullet 1,2-\left(\mathrm{CH}_{2} \mathrm{hpp}\right)_{2}-\mathrm{C}_{6} \mathrm{H}_{4}$ (Compound 10)}

This coordination was attempted on an NMR scale. A solution of 1,2$\left(\mathrm{CH}_{2} \mathrm{hpp}\right)_{2}-\mathrm{C}_{6} \mathrm{H}_{4}$ in benzene was added to an equimolar amount of $\mathrm{NaN}\left\{\mathrm{SiMe}_{3}\right\}_{2}$. ${ }^{1} \mathrm{H}-\mathrm{NMR}$ data were obtained for the resultant orange solution. Small crystals formed in the NMR tube but could not be retrieved. The $\mathrm{C}_{6} \mathrm{D}_{6}$ was removed by evaporation in vacuo. Attempts to redissolve the resultant solid in toluene then toluene/THF then THF, all caused white powder to crash out. No crystals were therefore obtained.

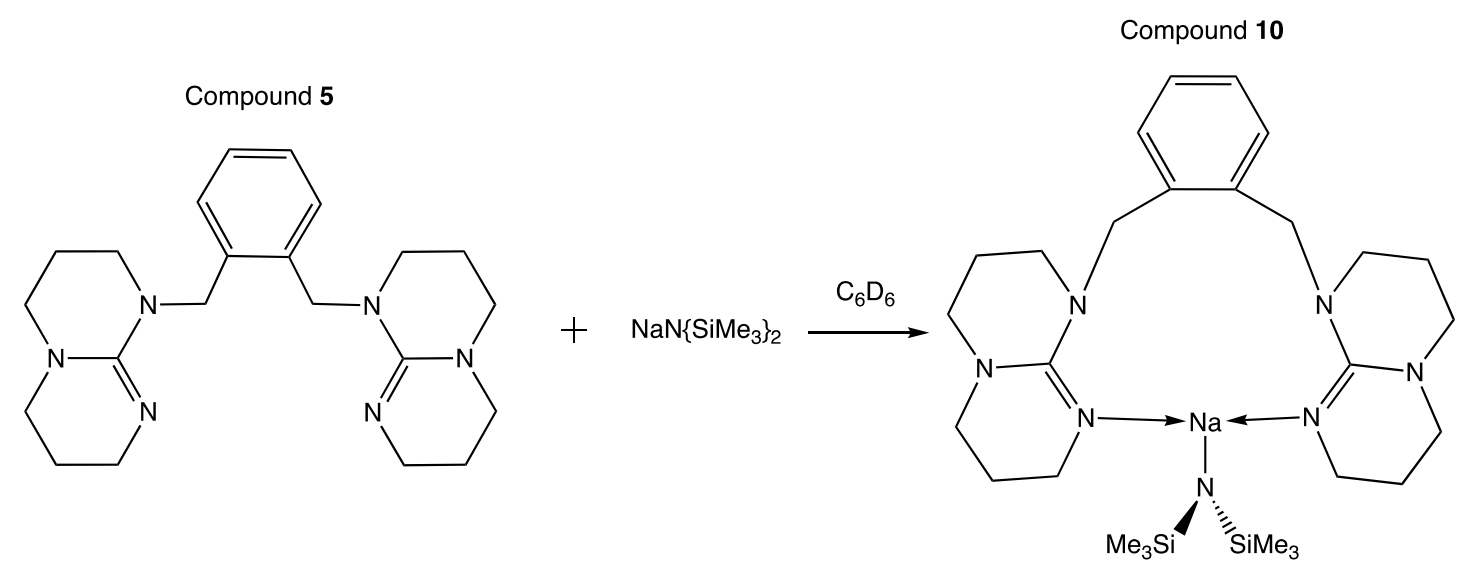

Scheme 9: Synthesis of $\mathrm{NaN}\left\{\mathrm{SiMe}_{3}\right\}_{2} \bullet 1,2-\left(\mathrm{CH}_{2} \mathrm{hpp}\right)_{2}-\mathrm{C}_{6} \mathrm{H}_{4}$ (Without a crystal structure bonding mode is not confirmed)

The ${ }^{1} \mathrm{H}-\mathrm{NMR}$ data obtained for this coordination attempt shows the same pattern of change from the uncomplexed ligand as with the attempt with $\mathrm{LiN}\left\{\mathrm{SiMe}_{3}\right\}_{2}$ (compound 9). Also in a similar manner to the reaction with $\mathrm{LiN}\left\{\mathrm{SiMe}_{3}\right\}_{2}$, the ${ }^{1} \mathrm{H}-\mathrm{NMR}$ of compound 10 reveals two peaks for the $\mathrm{NaN}\left\{\mathrm{SiMe}_{3}\right\}_{2}$ methyl protons in a 5:1 ratio which again suggests that one of the six methyl groups is in a different environment. It was thought that this affect may have been specific to the lithium analogue due to the short $\mathrm{Li}-\mathrm{N}$ bond between lithium and $\mathrm{N}\left\{\mathrm{SiMe}_{3}\right\}_{2}$. However this affect is clearly also 
present in 10 which will have a longer metal- $\mathrm{N}$ bond due to the larger ionic radius of sodium.

\section{Synthesis and Characterisation of $\mathrm{KN}\left\{\mathrm{SiMe}_{3}\right\}_{2} \bullet 1,2-\left(\mathrm{CH}_{2} \mathrm{hpp}\right)_{2}-\mathrm{C}_{6} \mathrm{H}_{4}$} (Compound 11)

On an NMR scale, an equimolar amount of yellow $1,2-\left(\mathrm{CH}_{2} \mathrm{hpp}\right)_{2}-\mathrm{C}_{6} \mathrm{H}_{4}$ was added to a colourless solution of $\mathrm{KN}\left\{\mathrm{SiMe}_{3}\right\}_{2}$ in $\mathrm{C}_{6} \mathrm{D}_{6}$ (Scheme 10). Large colourless single crystals formed from the yellow solution upon standing at room temperature for 30 minutes. Consequently, a crystal structure was obtained for the complex. The NMR scale reaction was too small to obtain a yield. The synthesis was therefore scaled up, using toluene as a solvent resulting in a $94 \%$ yield.

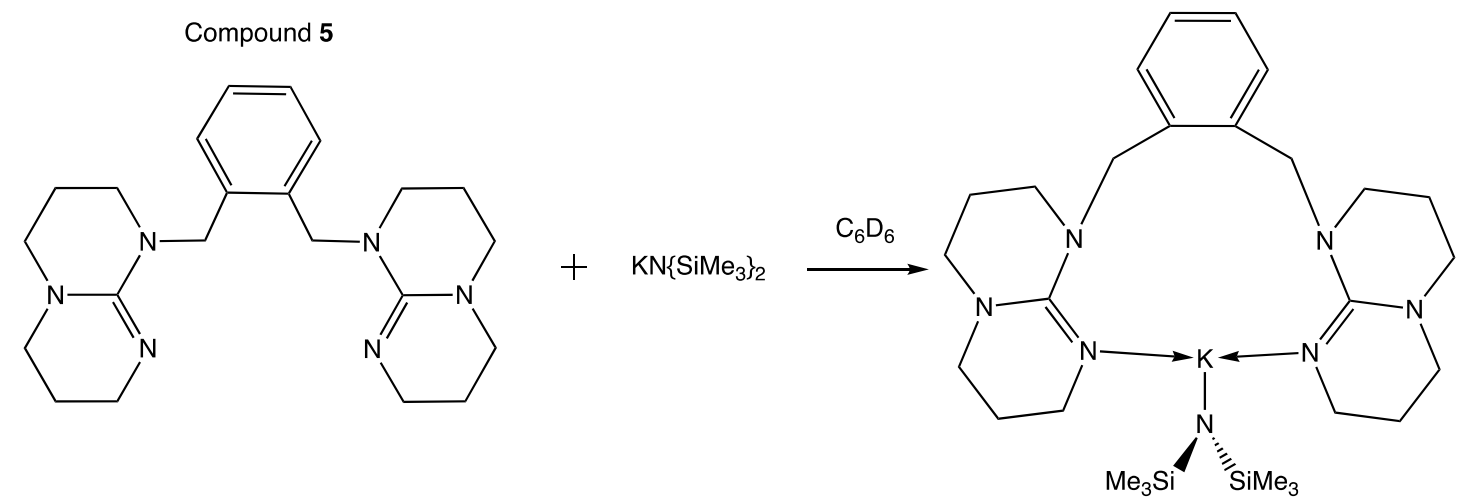

Scheme 10: Synthesis of KN\{SiMe $\}_{2} \bullet 1,2-\left(\mathrm{CH}_{2} \mathrm{hpp}\right)_{2}-\mathrm{C}_{6} \mathrm{H}_{4}$

${ }^{1} \mathrm{H}$ NMR data was collected for compound 11 . The recurring upfield trend in ligand resonances and downfield shift in the main $\mathrm{N}\left\{\mathrm{SiMe}_{3}\right\}_{2}{ }^{-}$resonance was also observed for this compound. The same 5:1 peak ratio for $\mathrm{N}\left\{\mathrm{SiMe}_{3}\right\}_{2}^{-}$ protons was also present. The methylene singlet peak shifted from $5.05 \mathrm{ppm}$ to $4.47 \mathrm{ppm}$ and as with compounds 9 and 10, an integration of $4 \mathrm{H}$ for this resonance suggests $1,2-\left(\mathrm{CH}_{2} \mathrm{hpp}\right)_{2}-\mathrm{C}_{6} \mathrm{H}_{4}$ had coordinated to $\mathrm{KN}\left\{\mathrm{SiMe}_{3}\right\}_{2}$ symmetrically. 
A crystal structure was obtained of 11 (Figure 20). A $\mathrm{C}_{6} \mathrm{D}_{6}$ solvent molecule seen to the right of the structure is part of the asymmetric unit. The crystal structure shows the $1,2-\left(\mathrm{CH}_{2} \mathrm{hpp}\right)_{2}-\mathrm{C}_{6} \mathrm{H}_{4}$ ligand has coordinated to a $\mathrm{KN}\left\{\mathrm{SiMe}_{3}\right\}_{2}$ monomer in a bidentate manner with a bite angle of $132.21^{\circ}$. The aromatic group and the hpp groups of the complexed ligand are close to perpendicular with an angle between them of $79.09^{\circ}$.
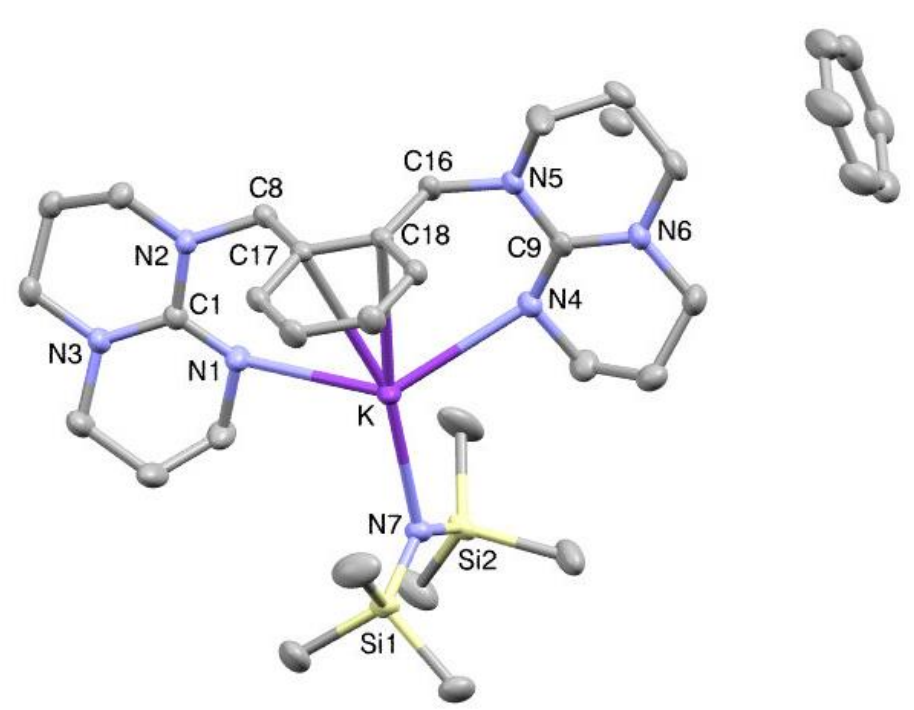

Figure 20: Thermal ellipsoid representation (50\%) of $\mathrm{KN}\left\{\mathrm{SiMe}_{3}\right\}_{2} \bullet 1,2-\left(\mathrm{CH}_{2} \mathrm{hpp}\right)_{2}-\mathrm{C}_{6} \mathrm{H}_{4}$. Selected bond lengths and angles have been reported in Tables 3 and 4 respectively All hydrogen atoms have been omitted for clarity

\begin{tabular}{|c|c|}
\hline Atoms of Bond & Bond Length $(\AA)$ \\
\hline $\mathrm{K} \mathrm{C}(17)$ & $3.1372(17)$ \\
\hline $\mathrm{K} \mathrm{C}(18)$ & $3.1057(13)$ \\
\hline $\mathrm{K} \mathrm{N}(1)$ & $2.8059(13)$ \\
\hline $\mathrm{K} \mathrm{N}(4)$ & $2.8284(13)$ \\
\hline $\mathrm{K} \mathrm{N}(7)$ & $2.6589(12)$ \\
\hline
\end{tabular}

Table 3: Selected bond lengths of compound 11 


\begin{tabular}{|c|c|}
\hline Atoms & Angle $\left(^{\circ}\right)$ \\
\hline $\mathrm{C}(17) \mathrm{C}(8) \mathrm{N}(2)$ & 115.31 \\
\hline $\mathrm{C}(18) \mathrm{C}(16) \mathrm{N}(5)$ & 115.48 \\
\hline
\end{tabular}

Table 4: Selected bond angles of compound 11

The bond lengths from the coordinating hpp nitrogens to potassium are on average $0.374 \AA$ longer than those of compound 4 . This, however, will be a result of the ionic radius of potassium being $0.36 \AA$ larger than that of sodium. 68

As shown in Table 3, the closest K---C bond distances are 3.1372 (17) $\AA$ and 3.1057 (13) A. These bonds are short enough to provide an $\eta^{2} \pi$ interaction with compound 11, which was not achieved in compound 4 . This is most likely because in compound $11,1,2-\left(\mathrm{CH}_{2} \mathrm{hpp}\right)_{2}-\mathrm{C}_{6} \mathrm{H}_{4}$ has coordinated to a $\mathrm{KN}\left\{\mathrm{SiMe}_{3}\right\}_{2}$ monomer so there less steric hindrance compared with compound 4 where there were two $\left.\mathrm{N}_{\{} \mathrm{SiMe}_{3}\right\}_{2}$ - groups ligated to the metal core. Furthermore, as previously mentioned, the coordination of both hpp groups to the potassium core holds the aromatic ring in a close enough position to enable some $\pi$ donation. This was not a factor in the means of coordination of $\mathrm{Ph}\left(\mathrm{CH}_{2} \mathrm{hpp}\right)$ to $\mathrm{NaN}\left\{\mathrm{SiMe}_{3}\right\}_{2}$ in compound 3 because each ligand had only one hpp group allowing for free movement of the benzyl group away from the metal due to steric bulk of the $\mathrm{N}\left\{\mathrm{SiMe}_{3}\right\}_{2}{ }^{-}$groups, rendering a $\pi$-interaction impossible.

This crystal structure provides insight into the 5:1 ratio of $\mathrm{N}\left\{\mathrm{SiMe}_{3}\right\}_{2}-$ peaks as seen in the ${ }^{1} \mathrm{H}$ NMR of all three 1,2 substituted ligand containing compounds. The structure shows that (due to the coordination mode of the ligand), one $\mathrm{SiMe}_{3}$ methyl group is closer to the arene group than the other 
five methyl groups. Therefore, the previously mentioned restricted rotation could be a result of an aromatic interaction between the arene group and the $\mathrm{SiMe}_{3}$ group (see Figure 19). If time had permitted, variable temperature NMR could have enabled further understanding of the behaviour of the $\mathrm{SiMe}_{3}$ groups in the structure. The two peaks may have collapsed into one upon heating the NMR sample as heating may have allowed free rotation around the $\mathrm{N}-\mathrm{Si}$ bond.

\section{Section Three: Coordination Attempts using the 1,3-( $\left.\mathrm{CH}_{2} \mathrm{hpp}\right)_{2}-$ $\mathrm{C}_{6} \mathrm{H}_{4}$ Ligand}

After the coordination success with $1,2-\left(\mathrm{CH}_{2} \mathrm{hpp}\right)_{2}-\mathrm{C}_{6} \mathrm{H}_{4}$ on $\mathrm{KN}\left\{\mathrm{SiMe}_{3}\right\}_{2}$, coordination attempts were made using the 1,3 substituted ligand: 1,3$\left(\mathrm{CH}_{2} \mathrm{hpp}\right)_{2}-\mathrm{C}_{6} \mathrm{H}_{4}$. It was hypothesised that coordination would occur in the same overall fashion but more of a $\pi$ interaction may occur.

\section{Synthesis of $1,3-\left(\mathrm{CH}_{2} \mathrm{hpp}\right)_{2}-\mathrm{C}_{6} \mathrm{H}_{4}$ (Compound 6)}

The synthesis of $1,3-\left(\mathrm{CH}_{2} \mathrm{hpp}\right)_{2}-\mathrm{C}_{6} \mathrm{H}_{4}$ was conducted using an analogous procedure to the syntheses of $\mathrm{Ph}\left(\mathrm{CH}_{2} \mathrm{hpp}\right)$ and $1,2-\left(\mathrm{CH}_{2} \mathrm{hpp}\right)_{2}-\mathrm{C}_{6} \mathrm{H}_{4}$ but using the $\alpha, \alpha^{\prime}$-dibromo- $m$-xylene (a 1,3 substituted bromide reagent).

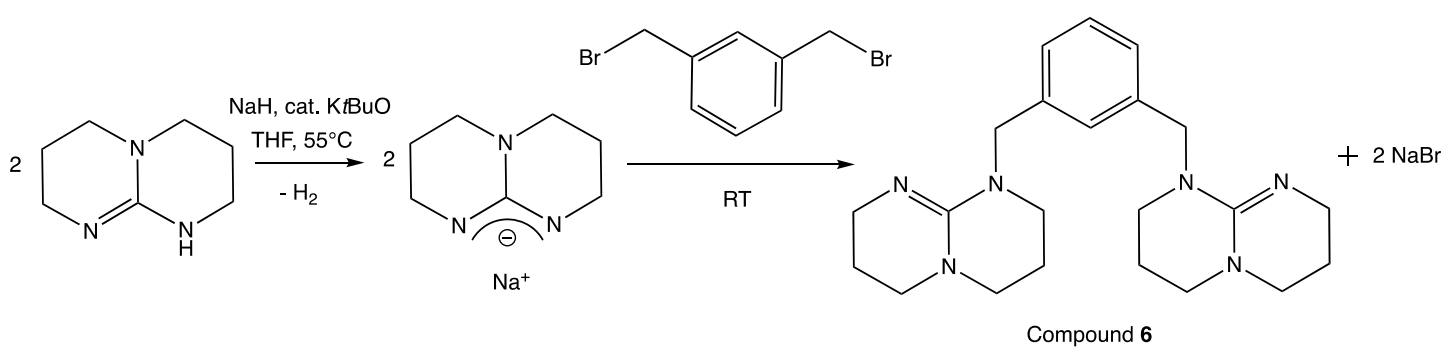

Scheme 11: Synthesis of 1,3-( $\left.\mathrm{CH}_{2} \mathrm{hpp}\right)_{2}-\mathrm{C}_{6} \mathrm{H}_{4}$ 
Synthesis and Characterisation of $\mathrm{KN}\left\{\mathrm{SiMe}_{3}\right\}_{2} \bullet 1,3-\left(\mathrm{CH}_{2} \mathrm{hpp}\right)_{2}-\mathrm{C}_{6} \mathrm{H}_{4}$ (Compound 12)

The attempt to coordinate $1,3-\left(\mathrm{CH}_{2} \mathrm{hpp}\right)_{2}-\mathrm{C}_{6} \mathrm{H}_{4}$ to $\mathrm{KN}\left\{\mathrm{SiMe}_{3}\right\}_{2}$ was performed in an NMR tube by following an analogous procedure for the synthesis of compound 11 (Scheme 12). However, crystallisation did not readily occur in the NMR tube this time. So, the $\mathrm{C}_{6} \mathrm{D}_{6}$ was removed in vacuo and the solid redissolved in toluene. Recrystallization from slow evaporation of toluene at room temperature provided crystals suitable for single crystal X-ray diffraction.

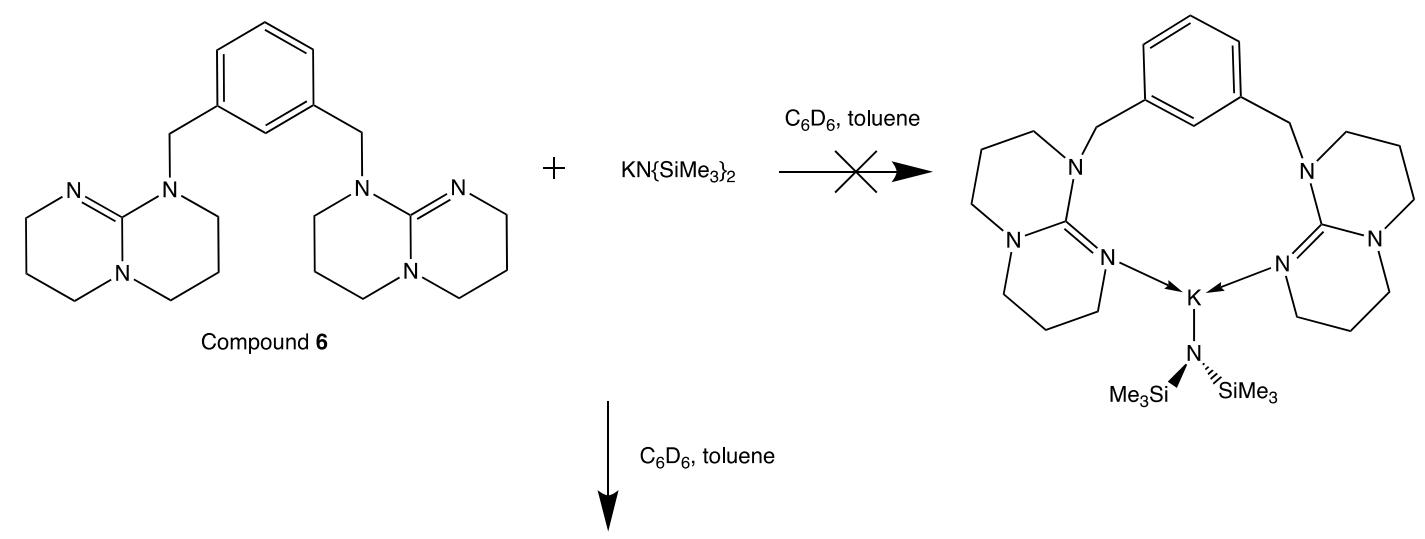<smiles></smiles>

Scheme 12: Synthesis of $\mathrm{KN}\left\{\mathrm{SiMe}_{3}\right\}_{2} \bullet 1,3-\left(\mathrm{CH}_{2} \mathrm{hpp}\right)_{2}-\mathrm{C}_{6} \mathrm{H}_{4}$ polymer 
${ }^{1} \mathrm{H}$ NMR analysis of compound 12 was performed. The NMR data showed a similar upfield shift in ligand peaks as was seen in the coordination of 1,2$\left(\mathrm{CH}_{2} \mathrm{hpp}\right)_{2}-\mathrm{C}_{6} \mathrm{H}_{4}$ to group 1 metals. The methylene proton peak shifted from $4.89 \mathrm{ppm}$ to $4.72 \mathrm{ppm}$. There is only one methylene peak observed in compound 12 still with an integration of $4 \mathrm{H}$ which, as discussed in section two, demonstrates that if coordination has occurred, it has done so through both hpp groups. An upfield shift was observed in all aromatic and hpp proton resonances. The protons of $\mathrm{KN}\left\{\mathrm{SiMe}_{3}\right\}_{2}$ have a chemical shift of 0.14 ppm in $\mathrm{C}_{6} \mathrm{D}_{6}$, this peak has shifted downfield to $0.22 \mathrm{ppm}$ upon the addition of $1,3-\left(\mathrm{CH}_{2} \mathrm{hpp}\right)_{2}-\mathrm{C}_{6} \mathrm{H}_{4}$.

In contrast to the coordination mode of the $1,2-\left(\mathrm{CH}_{2} \mathrm{hpp}\right)_{2}-\mathrm{C}_{6} \mathrm{H}_{4}$ ligand to $\mathrm{KN}\left\{\mathrm{SiMe}_{3}\right\}_{2}$ in compound 11, from the crystal structure obtained it can be determined that compound $\mathbf{1 2}$ is a polymer in the solid state. To portray the structure of 12 clearly, three different figures $(21,22$, and 23) are provided below.

The asymmetric unit of compound 12 (Figure 21) is comprised of half of a 1,3-( $\left.\mathrm{CH}_{2} \mathrm{hpp}\right)_{2}-\mathrm{C}_{6} \mathrm{H}_{4}$ ligand coordinated to what appeared to be a $\mathrm{KN}\left\{\mathrm{SiMe}_{3}\right\}_{2}$ monomer.

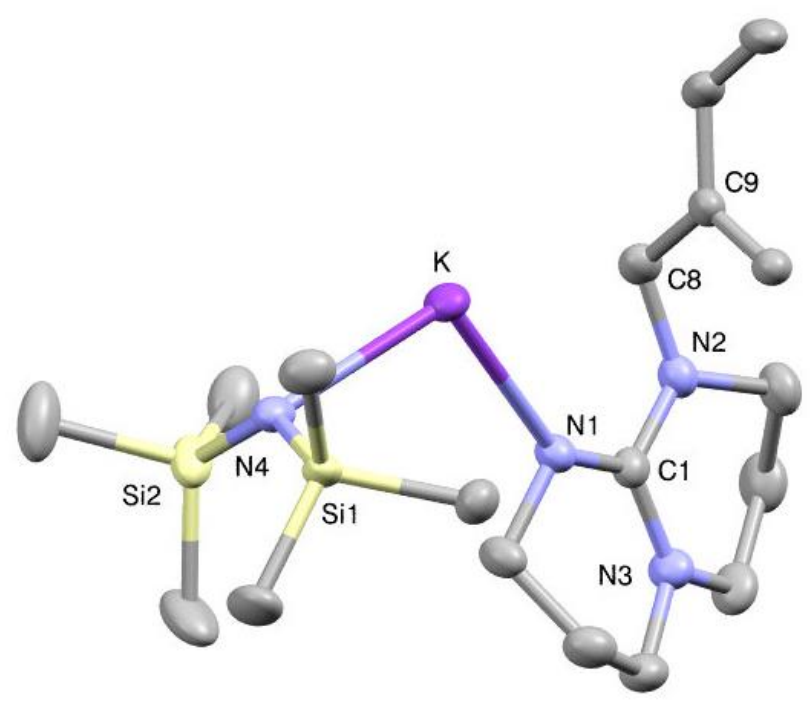

Figure 21: Thermal ellipsoid representation (50\%) of the asymmetric unit of compound 12. All hydrogen atoms have been omitted for clarity 
As Figure 21 does not allow for the role the ligand plays in the structure to be easily visualised, another depiction of the structure (Figure 22) shows an extension of the structure from the boundaries of the unit cell to highlight the function of the ligand of bridging $\mathrm{KN}\left\{\mathrm{SiMe}_{3}\right\}_{2}$ dimers.

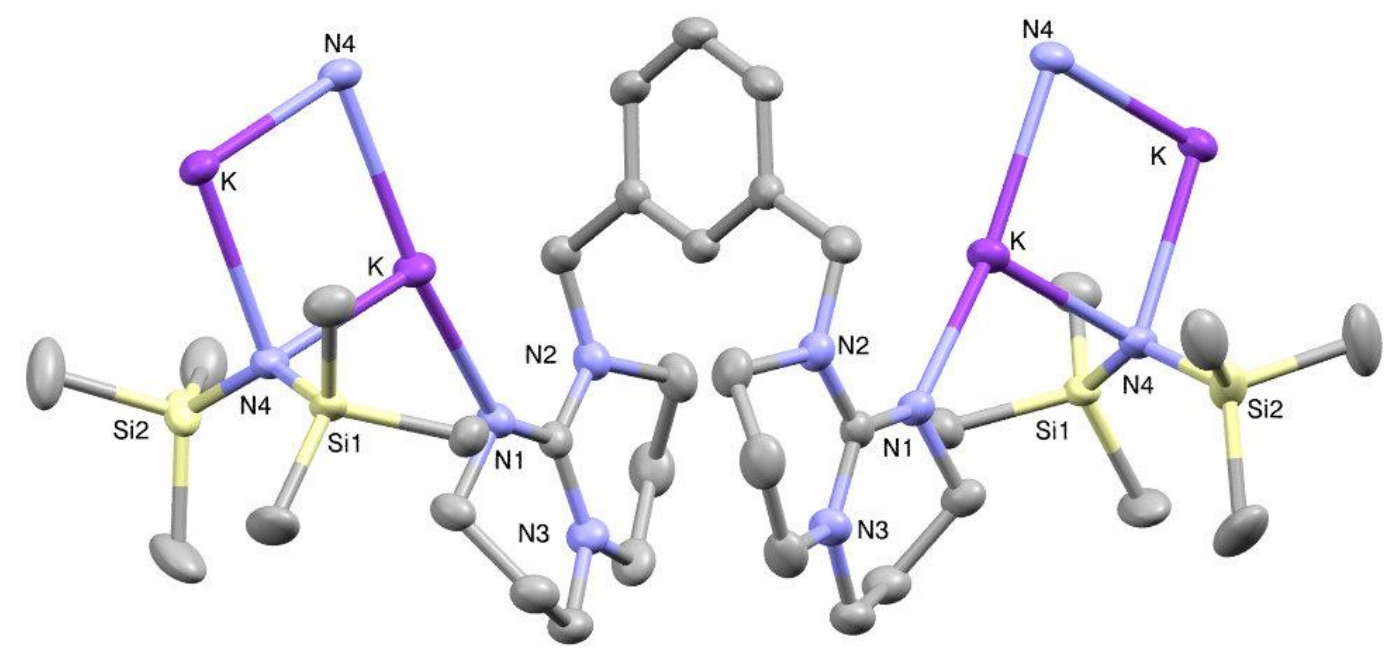

Figure 22: Extended Thermal ellipsoid representation (50\%) of compound 12. All hydrogen atoms have been omitted for clarity

The K-N4 bond length in 12 is $2.777(2) \AA$. This is longer than the equivalent bond length in 11. This lengthening can be attributed to the bridging coordination mode for $\mathrm{N}\left\{\mathrm{SiMe}_{3}\right\}_{2}$ group instead of monomeric $\mathrm{KN}\left\{\mathrm{SiMe}_{3}\right\}_{2}$.

The hpp units of the complexed ligand are approximately parallel to each other. The distance between the hpp units was approximated using the distance between the central carbons of the guanidine functionalities within a ligand unit with a length of $4.1713 \AA$.

Although it is not well illustrated in Scheme 12, the aromatic group and hpp groups in the coordinated ligand are nearly perpendicular to one another. 
They are positioned with an angle of $97.52^{\circ}$ (measuring from the plane of the aromatic ring to the plane of the guanidine functionality in the hpp group).

One final illustration of compound 12 is shown in Figure 23 to display the extended polymer structure which provides a clearer representation of the ligand in an alternating up and down pattern in a zig-zag like shape.

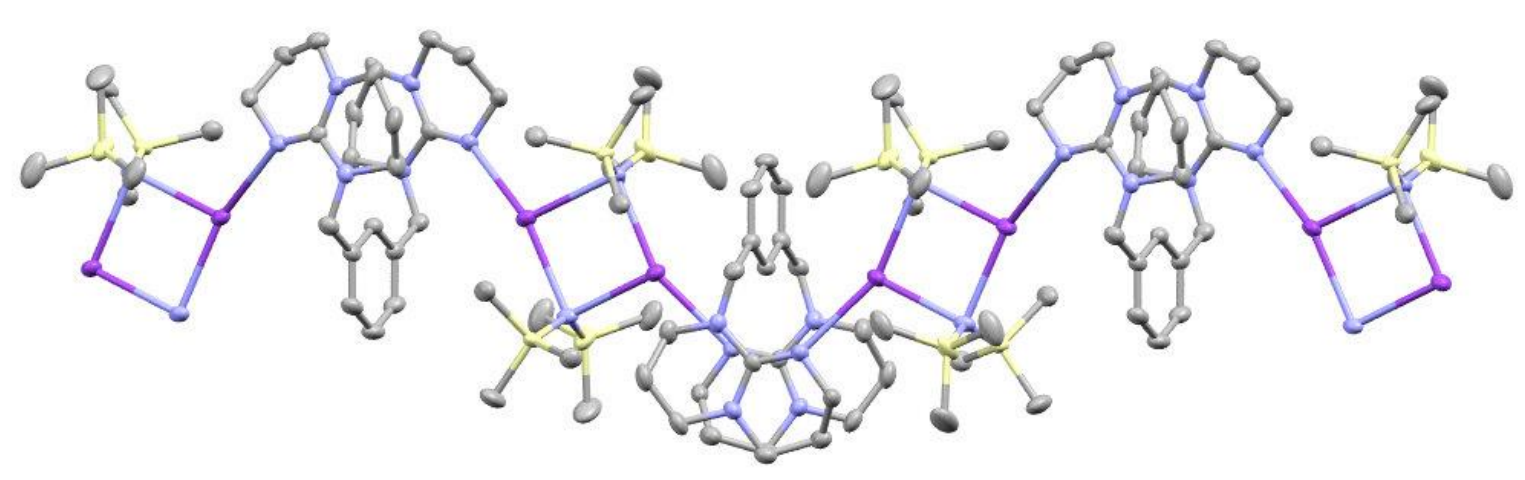

Figure 23: Extended Polymer thermal ellipsoid representation (50\%) of compound 12. All hydrogen atoms have been omitted for clarity

The coordination differences between compounds 11 and 12 can be attributed to the differences in the substitution pattern of hpp units around the aromatic ring. In 11, the lowest energy conformation possible was the coordination of the ligand to monomeric $\mathrm{KN}\left\{\mathrm{SiMe}_{3}\right\}_{2}$. However, the hpp units in 6 are too far apart to coordinate to the $\mathrm{KN}\left\{\mathrm{SiMe}_{3}\right\}_{2}$ in the same manner as observed in compound 11. The structure of compound 12 prevents the arene group from any $\pi$-interaction with potassium because compound 6 and the $\mathrm{KN}\left\{\mathrm{SiMe}_{3}\right\}_{2}$ dimer are acting as repeating units whereby the arene rings are nowhere near the potassium atoms. Therefore, the $\pi$-interaction ability of $1,3-\left(\mathrm{CH}_{2} \mathrm{hpp}\right)_{2}-\mathrm{C}_{6} \mathrm{H}_{4}$ as a ligand is not the same as that of $1,2-\left(\mathrm{CH}_{2} \mathrm{hpp}\right)_{2}-\mathrm{C}_{6} \mathrm{H}_{4}$. 
In the crystal structure there is a ratio of $2 \mathrm{KN}\left\{\mathrm{SiMe}_{3}\right\}_{2}$ monomers for every 1 ligand. As equimolar amounts of $\mathrm{KN}\left\{\mathrm{SiMe}_{3}\right\}_{2}$ and $1,3-\left(\mathrm{CH}_{2} \mathrm{hpp}\right)_{2}-\mathrm{C}_{6} \mathrm{H}_{4}$ were added together, there should therefore be evidence of free ligand in the ${ }^{1} \mathrm{H}$ NMR for compound 12. However, all the peaks have shifted with no remaining peaks from the uncomplexed ligand which shows that the crystal structure obtained is not representative of the chemistry in the solution phase.

\section{Section Four: Coordination Attempts using the 1,4-( $\left.\mathrm{CH}_{2} \mathrm{hpp}\right)_{2}-$ $\mathrm{C}_{6} \mathrm{H}_{4}$ Ligand}

\section{Synthesis of $1,4-\left(\mathrm{CH}_{2} \mathrm{hpp}\right)_{2}-\mathrm{C}_{6} \mathrm{H}_{4}$ (Compound 7)}

The synthesis of $1,4-\left(\mathrm{CH}_{2} \mathrm{hpp}\right)_{2}-\mathrm{C}_{6} \mathrm{H}_{4}$ was conducted using an analogous procedure to the syntheses of $\mathrm{Ph}\left(\mathrm{CH}_{2} \mathrm{hpp}\right), 1,2-\left(\mathrm{CH}_{2} \mathrm{hpp}\right)_{2}-\mathrm{C}_{6} \mathrm{H}_{4}$ and 1,3$\left(\mathrm{CH}_{2} \mathrm{hpp}\right)_{2}-\mathrm{C}_{6} \mathrm{H}_{4}$ but using $\alpha, \alpha^{\prime}$-dibromo- $p$-xylene (the 1,4 substituted bromide starting material) (Scheme 13)

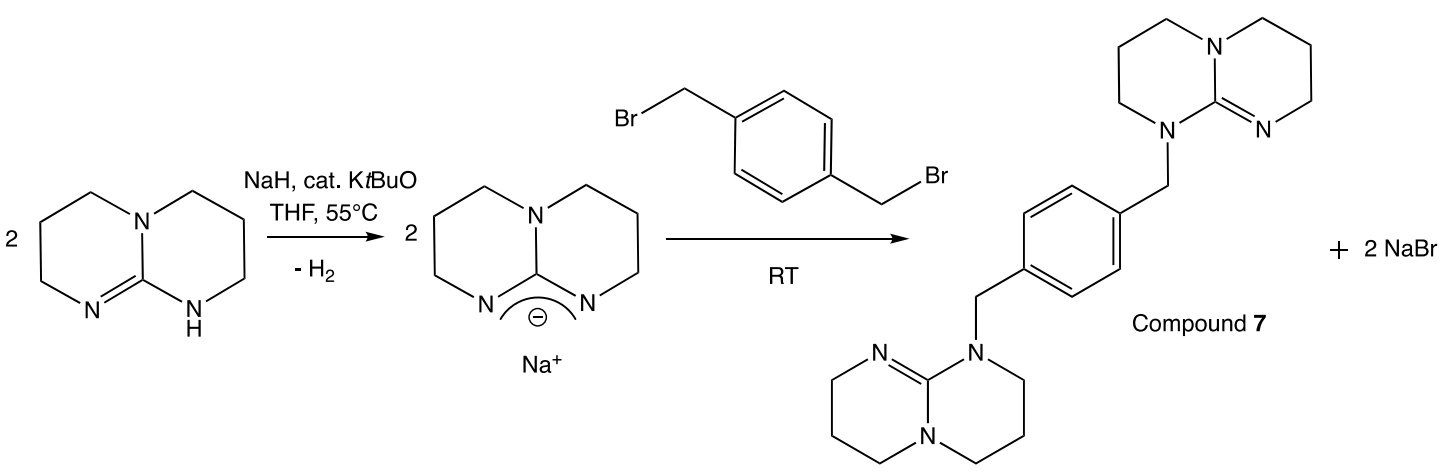

Scheme 13: Synthesis of 1,4-( $\left.\mathrm{CH}_{2} \mathrm{hpp}\right)_{2}-\mathrm{C}_{6} \mathrm{H}_{4}$ 


\section{Synthesis and Characterisation of $\mathrm{KN}\left\{\mathrm{SiMe}_{3}\right\}_{2} \bullet 1,4-\left(\mathrm{CH}_{2} \mathrm{hpp}\right)_{2}-\mathrm{C}_{6} \mathrm{H}_{4}$ (Compound 13)}

An analogous synthesis using the 1,4 substituted ligand (compound 7) was also attempted. As 7 has hpp groups further away from one another than $\mathbf{5}$, a similar result to that obtained for compound 12 was anticipated, whereby a polymer consisting of alternating ligand and $\mathrm{KN}\left\{\mathrm{SiMe}_{3}\right\}_{2}$ dimers in a chain would be synthesised. However, an alternative conformation can also be envisaged whereby the symmetric arrangement of hpp units around the arene ring in 1,4- $\left(\mathrm{CH}_{2} \mathrm{hpp}\right)_{2}-\mathrm{C}_{6} \mathrm{H}_{4}$ could allow for a coordination similar to that seen in compound 11 but with a greater aromatic interaction due to the potassium situated directly beneath the arene ring, instead of off to one side as seen in compound 11. This could allow for 7 to have an $\eta^{6}$ interaction with potassium.

The synthesis was attempted on an NMR scale in $\mathrm{C}_{6} \mathrm{D}_{6}$ via the addition of 7 to $\mathrm{KN}\left\{\mathrm{SiMe}_{3}\right\}_{2}$ (Scheme 13). The product precipitated from solution although enough was soluble to obtain ${ }^{1} \mathrm{H}$ NMR data. The powdering out of the product indicated that a polymer may have formed. Repeated recrystallization attempts were unsuccessful. However, NMR data was obtained.
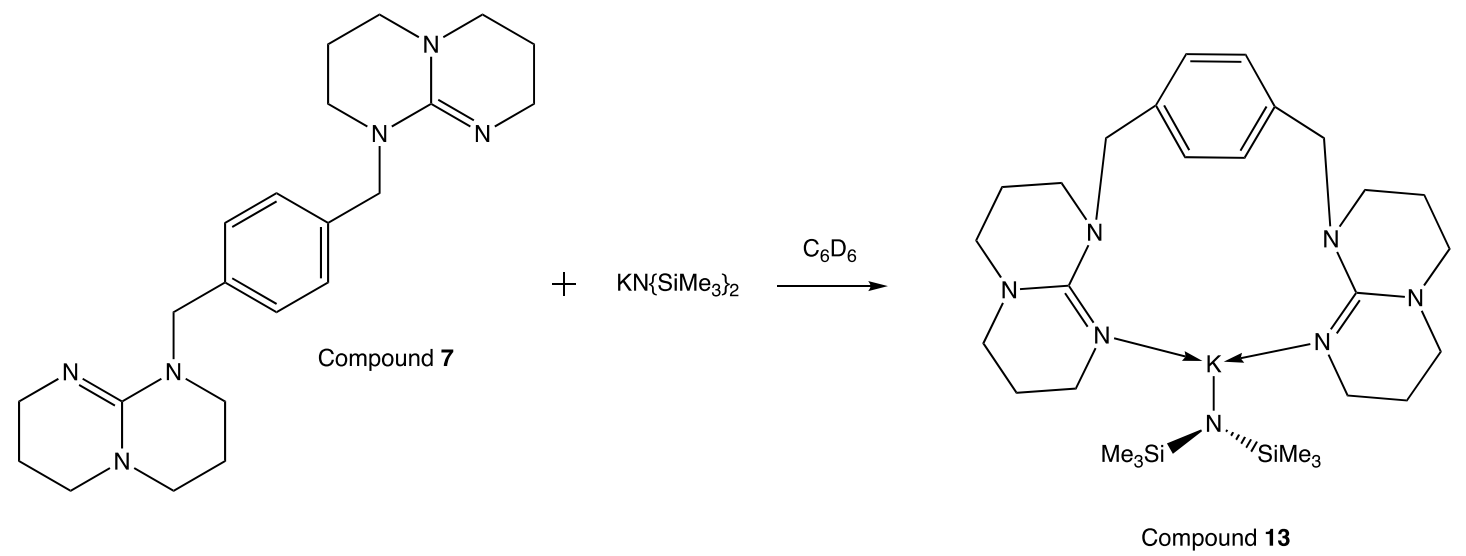

Scheme 13: Synthesis of KN\{SiMe $\}_{2} \bullet 1,4-\left(\mathrm{CH}_{2} \mathrm{hpp}\right)_{2}-\mathrm{C}_{6} \mathrm{H}_{4}$

(Without a crystal structure bonding mode is not confirmed) 
The ${ }^{1} \mathrm{H}-\mathrm{NMR}$ spectrum for this compound showed similar characteristics to the previously discussed reactions. An upfield shift in the singlet methylene resonance from $4.87 \mathrm{ppm}$ to $4.73 \mathrm{ppm}$ was observed. There is only one aromatic peak for 7 as all four aromatic protons are in the same environment. The aromatic resonance shifted from $7.43 \mathrm{ppm}$ to $7.37 \mathrm{ppm}$ upon the proposed coordination to $\mathrm{KN}\left\{\mathrm{SiMe}_{3}\right\}_{2}$. The peaks assigned to all hpp protons are also upfield compared to the free ligand.

The $\mathrm{N}\left\{\mathrm{SiMe}_{3}\right\}_{2}-$ proton peak has shifted downfield from $0.14 \mathrm{ppm}$ to 0.19

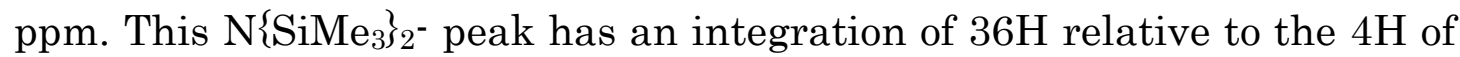
the methylene peak. This means there are two $\mathrm{KN}\left\{\mathrm{SiMe}_{3}\right\}_{2}$ (or one $\mathrm{KN}\left\{\mathrm{SiMe}_{3}\right\}_{2}$ dimer) for every one ligand. This is intriguing because 1,4$\left(\mathrm{CH}_{2} \mathrm{hpp}\right)_{2}-\mathrm{C}_{6} \mathrm{H}_{4}$ and $\mathrm{KN}\left\{\mathrm{SiMe}_{3}\right\}_{2}$ were both soluble in $\mathrm{C}_{6} \mathrm{D}_{6}$ and were mixed in equimolar amounts. It can be hypothesised that the remaining ligand was involved in another coordination, this second product may have been the less soluble component of the mixture which precipitated from solution.

\section{Section Five: Coordination Attempts using the $1,3,5^{-}\left(\mathrm{CH}_{2} \mathrm{hpp}\right)_{3^{-}}$ $\mathrm{C}_{6} \mathrm{H}_{3}$ Ligand}

\section{Synthesis of $1,3,5-\left(\mathrm{CH}_{2} \mathrm{hpp}\right)_{3}-\mathrm{C}_{6} \mathrm{H}_{3}$ (Compound 8)}

The synthesis of $1,3,5-\left(\mathrm{CH}_{2} \mathrm{hpp}\right)_{2}-\mathrm{C}_{6} \mathrm{H}_{3}$ was conducted using an analogous procedure to the syntheses of $\mathbf{1}, \mathbf{5}, 6$ and 7 but using the 1,3,5tris(bromomethyl)benzene. 


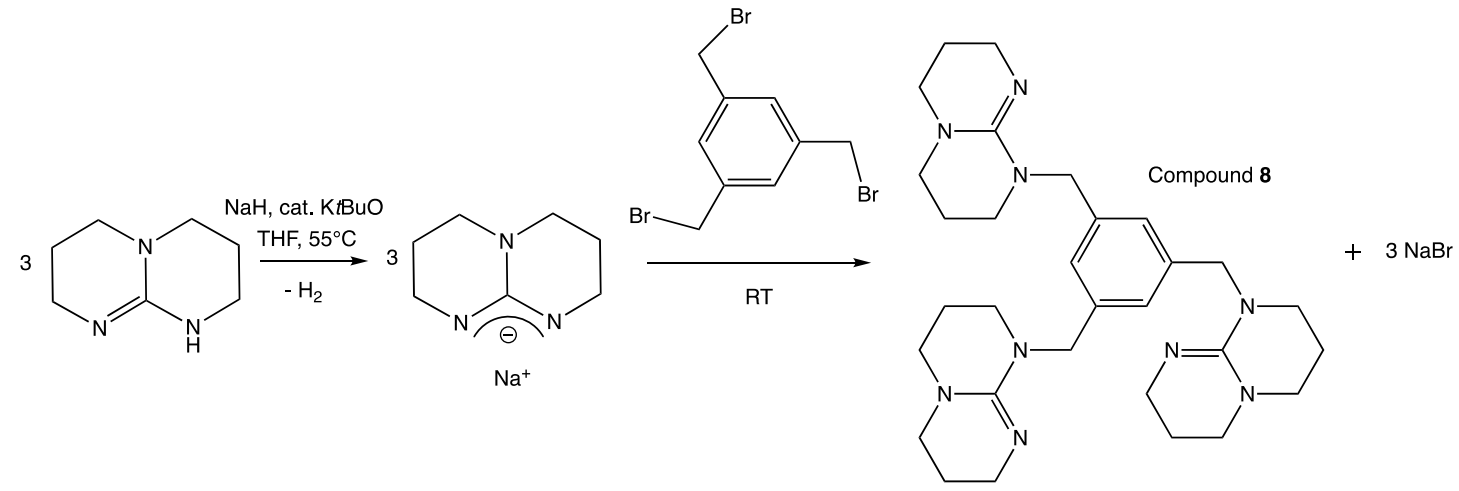

Scheme 14: Synthesis of $1,3,5-\left(\mathrm{CH}_{2} \mathrm{hpp}\right)_{3}-\mathrm{C}_{6} \mathrm{H}_{3}$

Synthesis and Characterisation of $\mathrm{KN}\left\{\mathrm{SiMe}_{3}\right\}_{2} \bullet 1,3,5-\left(\mathrm{CH}_{2} \mathrm{hpp}\right)_{3}-\mathrm{C}_{6} \mathrm{H}_{3}$ (Compound 14)

Initially, this synthesis was attempted with THF as a solvent. Crystallisation occurred at $-30^{\circ} \mathrm{C}$, however the crystals were found to be unreacted ligand. This could have been caused by THF competing as a ligand with compound 8 for the potassium centre. To bypass this issue, the synthesis was reattempted using toluene, as it is a non-coordinating solvent (Scheme 15). A slow crystallisation from toluene was attempted but no crystals large enough for single crystal X-ray diffraction were produced.
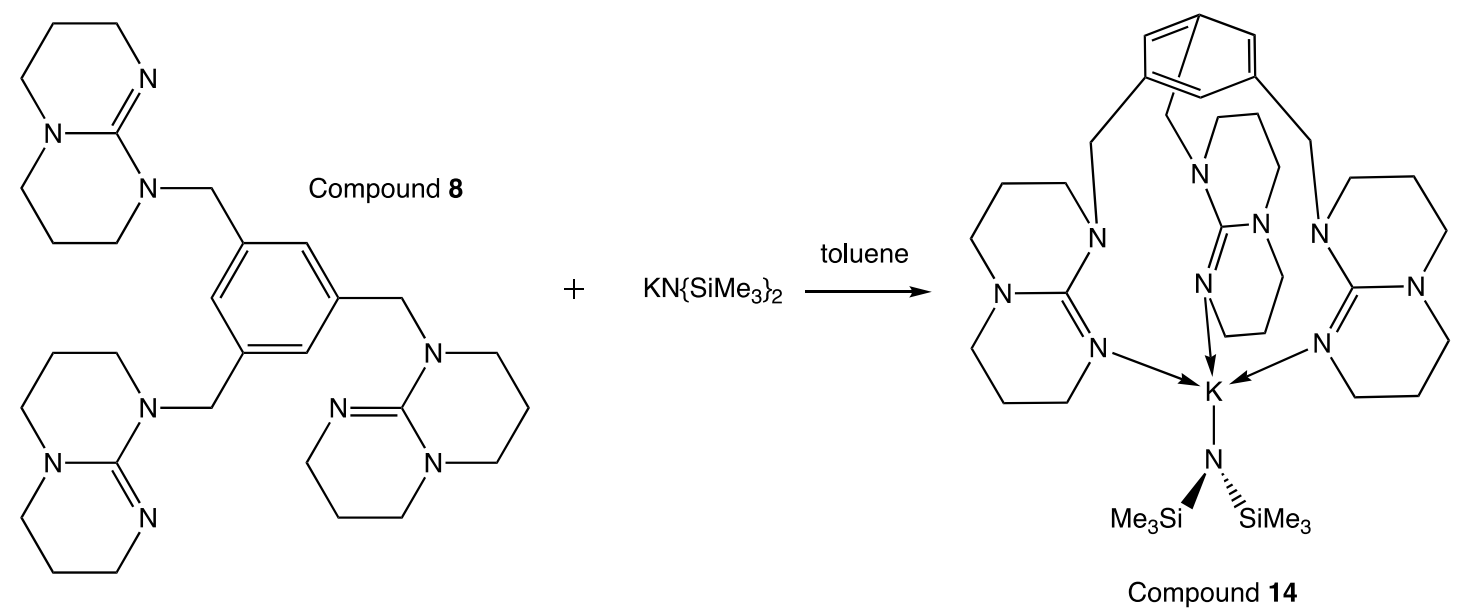

Scheme 15: Synthesis of KN $\left\{\mathrm{SiMe}_{3}\right\}_{2} \bullet 1,3,5-\left(\mathrm{CH}_{2} \mathrm{hpp}\right)_{3}-\mathrm{C}_{6} \mathrm{H}_{3}$

(Without a crystal structure bonding mode is not confirmed) 
The NMR data obtained indicated coordination of the ligand had occurred. In the same way as the previously described syntheses in this chapter, the ${ }^{1} \mathrm{H}$ NMR resonances from compound 8 were shifted upfield upon adding to $\mathrm{KN}\left\{\mathrm{SiMe}_{3}\right\}_{2}$. This ligand has only one aromatic environment because the three $\mathrm{CH}_{2}$-hpp groups are symmetrically positioned around the ring. The singlet resonance assigned to these three aromatic protons shifted from 7.41 ppm to $7.20 \mathrm{ppm}$ upon addition to $\mathrm{KN}\left\{\mathrm{SiMe}_{3}\right\}_{2}$. This is a small change so it is unlikely a $\pi$-interaction has occurred. There were still 6 resonances for the hpp protons (three triplets and two quintets). If coordination had occurred, the ligand must have coordinated symmetrically with all three hpp groups as none of them were in different environments and all proton resonances had the expected integrations. Furthermore, the methylene proton peak has shifted from $4.92 \mathrm{ppm}$ to $4.68 \mathrm{ppm}$ and appears as a single resonance, further evidence that all three hpp groups are in the same environment. This in itself strongly suggests that coordination may be occurring in solution.

\section{Summary and Conclusions}

To combat solubility problems, group one bis(trimethylsilyl)amide $\left(\mathrm{N}\left\{\mathrm{SiMe}_{3}\right\}_{2}{ }^{-}\right)$salts were used as a soluble metal model in proof of concept studies. A successful coordination of the $\mathrm{Ph}\left(\mathrm{CH}_{2} \mathrm{hpp}\right)$ ligand to $\mathrm{NaN}\left\{\mathrm{SiMe}_{3}\right\}_{2}$ was achieved. The NMR data for this was in accordance to that of attempts with $\mathrm{LiN}\left\{\mathrm{SiMe}_{3}\right\}_{2}$ and $\mathrm{KN}\left\{\mathrm{SiMe}_{3}\right\}_{2}$ although no crystallisation occurred with these analogous reactions. Solvent issues led to the abandonment of THF in place of non-coordinating toluene.

1,2-( $\left.\mathrm{CH}_{2} \mathrm{hpp}\right)_{2}-\mathrm{C}_{6} \mathrm{H}_{4}$ was successfully used as a ligand, coordinating to the potassium centre of monomeric $\mathrm{KN}\left\{\mathrm{SiMe}_{3}\right\}_{2}$ with an $\eta^{2} \pi$-interaction. This shows that 1,2-( $\left.\mathrm{CH}_{2} \mathrm{hpp}\right)_{2}-\mathrm{C}_{6} \mathrm{H}_{4}$ has the potential to be used as a bidentate 
ligand and can form both $\sigma$ and $\pi$ interactions as hypothesised. No crystal structures could be obtained for the analogous coordination with $\mathrm{LiN}\left\{\mathrm{SiMe}_{3}\right\}_{2}$ and $\left.\mathrm{NaN}_{2} \mathrm{SiMe}_{3}\right\}_{2}$. Attempts to synthesise an analogue of this compound using 1,3-( $\left(\mathrm{CH}_{2} \mathrm{hpp}\right)_{2}-\mathrm{C}_{6} \mathrm{H}_{4}$ were unsuccessful but resulted in the synthesis of a polymer in solid state, where the $\mathrm{KN}\left\{\mathrm{SiMe}_{3}\right\}_{2}$ remained dimeric and acted as a linker between $1,3-\left(\mathrm{CH}_{2} \mathrm{hpp}\right)_{2}-\mathrm{C}_{6} \mathrm{H}_{4}$ units. This unforeseen result led to attempts to coordinate $1,4-\left(\mathrm{CH}_{2} \mathrm{hpp}\right)_{2}-\mathrm{C}_{6} \mathrm{H}_{4}$ and 1,3,5-( $\left.\mathrm{CH}_{2} \mathrm{hpp}\right)_{3}-\mathrm{C}_{6} \mathrm{H}_{3}$ to $\mathrm{KN}\left\{\mathrm{SiMe}_{3}\right\}_{2}$. No crystals suitable for single crystal $\mathrm{X}$-ray diffraction were synthesised, but NMR data supports their syntheses.

From the three novel crystal structures described in Chapter Two, it can be inferred that there is a level of unpredictability involved in whether the compounds will be monomers, dimers or polymers. This is most likely due to the tendency of group one [N\{SiMe3\}2]- salts to readily form dimers. If $\mathrm{NaN}\left\{\mathrm{SiMe}_{3}\right\}_{2}$ and $\mathrm{KN}\left\{\mathrm{SiMe}_{3}\right\}_{2}$ were not stable in a dimeric conformation, compounds 4 and 12 would not have crystallised as they did. 


\section{Chapter Three}

\section{Coordination Attempts of Arene-hpp Ligands with Pnictogens}

\section{Introduction}

The proof of concept experiments with group one metal salts conducted in Chapter Two showed that 1,2-( $\left.\mathrm{CH}_{2} \mathrm{hpp}\right)_{2}-\mathrm{C}_{6} \mathrm{H}_{4}$ has an ability to coordinate to a metal centre. Obtaining a crystal structure of $\mathrm{KN}\left\{\mathrm{SiMe}_{3}\right\}_{2} \bullet 1,2$ $\left(\mathrm{CH}_{2} \mathrm{hpp}\right)_{2}-\mathrm{C}_{6} \mathrm{H}_{4}$ showed that the ligand could form a dative bond through the lone pair on nitrogen atoms of the hpp guanidine groups, with a concomitant aromatic interaction between the arene group and the potassium. However, this arene-metal interaction was an $\eta 2$ interaction instead of the $\eta 6$ interaction aspired to. Therefore, to expand the proof of concept studies in this research, attempts to coordinate $1,2-\left(\mathrm{CH}_{2} \mathrm{hpp}\right)_{2}-\mathrm{C}_{6} \mathrm{H}_{4}$ to metal salts of bismuth and antimony were conducted. Bismuth and antimony are known for their ability to readily form $\pi$-interactions with arene groups. 69 Therefore, the aim of this section of the project was to determine whether the $1,2-\left(\mathrm{CH}_{2} \mathrm{hpp}\right)_{2}-\mathrm{C}_{6} \mathrm{H}_{4}$ ligand had the capacity to form dative bonds through both of the hpp groups to a metal, whilst simultaneously having an $\eta 6$ arene-metal interaction.

\section{Attempted Synthesis of $\mathrm{BiPh}_{3} \bullet 1,2-\left(\mathrm{CH}_{2} \mathrm{hpp}\right)_{2}-\mathrm{C}_{6} \mathrm{H}_{4}$}

The first synthesis attempted was the coordination of $1,2-\left(\mathrm{CH}_{2} \mathrm{hpp}\right)_{2}-\mathrm{C}_{6} \mathrm{H}_{4}$ to the readily available organometallic reagent $\mathrm{BiPh}_{3}($ Scheme 16). The expected outcome of this experiment was a coordination similar to that of $\mathrm{KN}\left(\left\{\mathrm{SiMe}_{3}\right\}_{2}\right)$ but with a stronger aromatic interaction due to the increased capacity for bismuth to $\pi$-bond compared with potassium. 


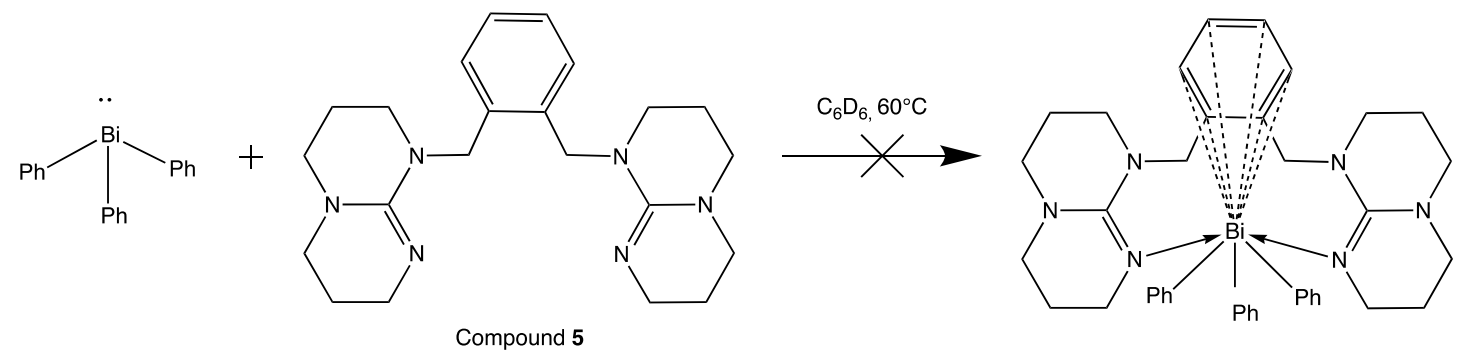

Scheme 16: Attempted Synthesis of $\mathrm{BiPh}_{3} \bullet 1,2-\left(\mathrm{CH}_{2} \mathrm{hpp}\right)_{2}-\mathrm{C}_{6} \mathrm{H}_{4}$

Both the ligand and metal salt were dissolved in $\mathrm{C}_{6} \mathrm{D}_{6}$ and the ligand solution was added to the $\mathrm{BiPh}_{3}$ solution. ${ }^{1} \mathrm{H}-\mathrm{NMR}$ analysis indicated no coordination had occurred as the resonances from the ligand had not shifted. The sample was then heated to $60^{\circ} \mathrm{C}$ to overcome any potential activation barrier for coordination to occur. However, once again no change was present in the ${ }^{1} \mathrm{H}-\mathrm{NMR}$ spectrum. It was reasoned that the lack of coordination was likely due to the bulk of the phenyl groups on $\mathrm{BiPh}_{3}$ providing steric hindrance at the metal. There are examples described in the literature of other ligands coordinating to $\mathrm{BiPh}_{3}$, resulting in fivecoordinate bismuth complexes. ${ }^{70}, 71$ Therefore, as the $\mathrm{BiPh}_{3}$ can be coordinated by additional ligands, the problem in this experiment must be that the 1,2-( $\left(\mathrm{CH}_{2} \mathrm{hpp}\right)_{2}-\mathrm{C}_{6} \mathrm{H}_{4}$ ligand is incompatible with $\mathrm{BiPh}_{3}$ as the bulk of the phenyl groups does not leave sufficient space around each bismuth atom for the large hpp groups to be in close enough proximity to bind.

In an attempt to circumvent the steric problems associated with the use of $\mathrm{BiPh}_{3}$, with 1,2-( $\left.\mathrm{CH}_{2} \mathrm{hpp}\right)_{2}-\mathrm{C}_{6} \mathrm{H}_{4}$ as a ligand, an NMR scale reaction would have been attempted with $\mathrm{BiCl}_{3}$. However, $\mathrm{BiCl}_{3}$ is insoluble in both readily available NMR solvents for air sensitive work $\left(\mathrm{C}_{6} \mathrm{D}_{6}\right.$ and $\left.\mathrm{CD}_{3} \mathrm{CN}\right)$, a coordination attempt with $\mathrm{BiCl}_{3}$ was not examined further. 


\section{Attempted Synthesis and Characterisation of $\mathrm{BiCl}_{2} \mathrm{Ph} \bullet 1,2-\left(\mathrm{CH}_{2} \mathrm{hpp}\right)_{2}-\mathrm{C}_{6} \mathrm{H}_{4}$ (Compound 15)}

Due to the proposed bulk issues with $\mathrm{BiPh}_{3}$ and the solubility issues of $\mathrm{BiCl}_{3}$, a bismuth salt with two chloride ligands and one phenyl ligand was synthesised. Chloride ligands are smaller than phenyl groups, which would allow for additional ligands to coordinate, but the presence of one phenyl would make the metal salt more soluble than $\mathrm{BiCl}_{3}$. The previously reported synthesis by Hoge et al. was followed, by stirring $\mathrm{BiPh}_{3}$ and $\mathrm{BiCl}_{3}$ in a 1:2 ratio in diethyl ether $\left(\mathrm{Et}_{2} \mathrm{O}\right)$ at room temperature. ${ }^{72}$ This establishes an equilibrium with ligands exchanging between metal centres such that the resultant bismuth product is obtained with the desired proportion of phenyl to chloride ligands. The reaction resulted in the formation of a cream-yellow precipitate.

The ${ }^{1} \mathrm{H}-\mathrm{NMR}$ spectrum of the product showed the phenyl proton peaks of $\mathrm{BiCl}_{2} \mathrm{Ph}$ were shifted downfield from those of $\mathrm{BiPh}_{3}$ as expected due to the presence of two electron withdrawing chloride groups. The spectrum also indicated that a small amount of $\mathrm{BiPh}_{3}$ was still present in solution. Integration of the peaks showed that the phenyl protons of $\mathrm{BiCl}_{2} \mathrm{Ph}$ and $\mathrm{BiPh}_{3}$ were in solution at a ratio of $5: 1$. As there is one phenyl group in $\mathrm{BiCl}_{2} \mathrm{Ph}$ and three phenyl groups in $\mathrm{BiPh}_{3}, \mathrm{BiCl}_{2} \mathrm{Ph}$ and $\mathrm{BiPh}_{3}$ were present in solution at a ratio of $15: 1$.

As the $\mathrm{BiCl}_{2} \mathrm{Ph}$ synthesised was not fully soluble in $\mathrm{Et}_{2} \mathrm{O}$, the reaction of $\mathrm{BiCl}_{2} \mathrm{Ph}$ with 1,2-( $\left.\mathrm{CH}_{2} \mathrm{hpp}\right)_{2}-\mathrm{C}_{6} \mathrm{H}_{4}$ was attempted in THF. (Scheme 17) A colourless solution of $\mathrm{BiCl}_{2} \mathrm{Ph}$ was added to a yellow solution of the ligand. Immediately, a brown precipitate formed. After 30 minutes, the solvent was removed under reduced pressure and an attempt to obtain ${ }^{1} \mathrm{H}$ NMR data of the product was conducted by attempting to dissolve the brown precipitate in $\mathrm{CD}_{3} \mathrm{CN}$. Despite the sparing solubility, sufficient product dissolved to 
acquire a ${ }^{1} \mathrm{H}$ NMR spectrum of the compound, but no crystals could be obtained due to solubility issues.

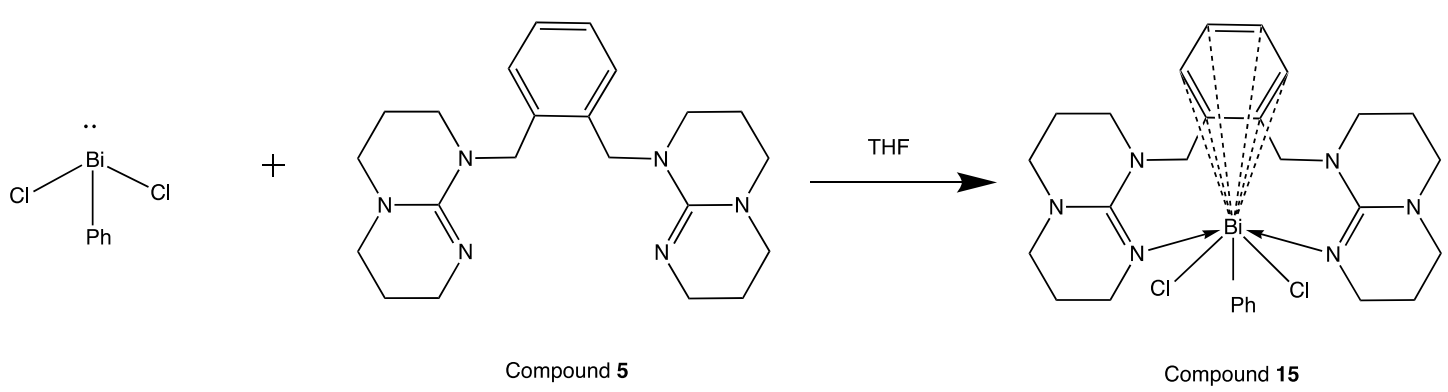

Scheme 17: Attempted Synthesis of $\mathrm{BiPh}_{3} \bullet 1,2-\left(\mathrm{CH}_{2} \mathrm{hpp}\right)_{2}-\mathrm{C}_{6} \mathrm{H}_{4}$

The ${ }^{1} \mathrm{H}$ NMR spectrum showed that the methylene peak of the ligand has shifted downfield from $4.55 \mathrm{ppm}$ to $4.64 \mathrm{ppm}$ with an integration of $4 \mathrm{H}$, which proves that if the ligand had coordinated, it had done so in a symmetric manner through both hpp groups. The four triplets of the hpp groups, which each had an integration of $4 \mathrm{H}$ in the uncoordinated ligand, converged into a single multiplet with an integration of $16 \mathrm{H}$. This could also be a result of coordination to a metal. The two quintets from the hpp groups of the ligand have the same chemical shift as they did in the uncoordinated ligand. The peak integrals for the $\mathrm{BiCl}_{2} \mathrm{Ph}$ protons do not match what would be expected. A doublet at $8.57 \mathrm{ppm}$ and a triplet at $7.50 \mathrm{ppm}$ integrate to $1 \mathrm{H}$ each with respect to the ligand resonances. A potential explanation for this could be that there may exist an equilibrium between $\mathrm{BiCl}_{2} \mathrm{Ph}, \mathrm{BiCl}_{3}$ and $\mathrm{BiClPh}_{2}$ and the ligand may have coordinated to a mixture of these bismuth salts. The ligand may have preferentially coordinated to $\mathrm{BiCl}_{3}$ due to its smaller size, which could explain the relative lack of phenyl protons in the ${ }^{1} \mathrm{H}$ NMR spectrum. The ${ }^{1} \mathrm{H}$ NMR data obtained supports the hypothesised coordination of $1,2-\left(\mathrm{CH}_{2} \mathrm{hpp}\right)_{2}-\mathrm{C}_{6} \mathrm{H}_{4}$ to $\mathrm{BiCl}_{2} \mathrm{Ph}$ but as crystallisation did not occur, no diffraction data could be obtained to confirm a coordination mode. 


\section{Attempted Synthesis and Characterisation of $\mathrm{SbCl}_{3} \bullet 1,2-\left(\mathrm{CH}_{2} \mathrm{hpp}\right)_{2}-\mathrm{C}_{6} \mathrm{H}_{4}$}

Antimony is above bismuth in group 15 of the periodic table so its ionic radius is smaller. $\mathrm{Sb}^{3+}$ has radius is $0.9 \AA$ compared with $\mathrm{Bi}^{3+}$ which has a radius of $1.17 \AA .68$ The smaller size of antimony makes its salts more soluble in moderately polar solvents (commonly used in air sensitive chemistry) in comparison with bismuth salts.

The coordination of $1,2-\left(\mathrm{CH}_{2} \mathrm{hpp}\right)_{2}-\mathrm{C}_{6} \mathrm{H}_{4}$ to $\mathrm{SbPh}_{3}$ was not attempted because the perceived coordination difficulties due to steric hindrance seen in the analogous coordination attempt with $\mathrm{BiPh}_{3}$ would be even more pronounced with $\mathrm{SbPh}_{3}$ given the smaller size of antimony. Therefore, the attempt to coordinate $1,2-\left(\mathrm{CH}_{2} \mathrm{hpp}\right)_{2}-\mathrm{C}_{6} \mathrm{H}_{4}$ to antimony used the $\mathrm{SbCl}_{3}$ starting material.

The synthesis was performed on an NMR scale. 1,2- $\left(\mathrm{CH}_{2} \mathrm{hpp}\right)_{2}-\mathrm{C}_{6} \mathrm{H}_{4}$ dissolved in $\mathrm{C}_{6} \mathrm{D}_{6}$ was added to $\mathrm{SbCl}_{3}$ dissolved in $\mathrm{C}_{6} \mathrm{D}_{6}$ (Scheme 18). A thick yellow precipitate immediately formed from the solution. The sample was transferred to a vial and the volatiles were removed under reduced pressure. The more polar NMR solvent available in the glovebox, $\mathrm{CD}_{3} \mathrm{CN}$, was added. The yellow compound was sufficiently soluble in $\mathrm{CD}_{3} \mathrm{CN}$ upon heating to allow acquisition of NMR data. Small colourless crystals appeared after 3 days sealed under $\mathrm{N}_{2}$ in a J. Young's tap NMR tube. A crystal structure was obtained (Figure 24) and a ${ }^{1} \mathrm{H}$ NMR spectrum was collected for the compound. 


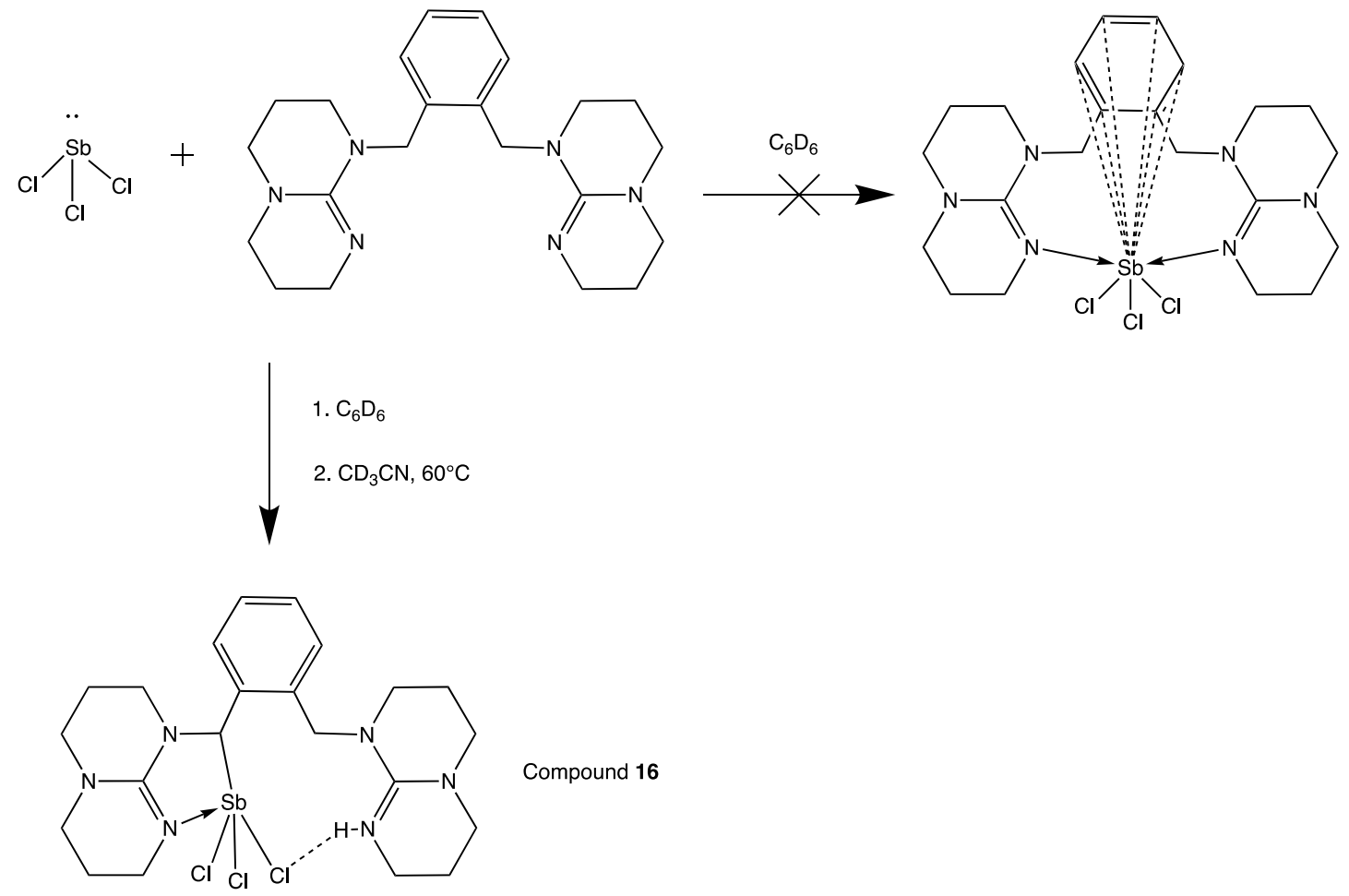

Scheme 18: Attempted Synthesis $\mathrm{SbCl}_{3} \bullet 1,2-\left(\mathrm{CH}_{2} \mathrm{hpp}\right)_{2}-\mathrm{C}_{6} \mathrm{H}_{4}$ and subsequent synthesis of $\mathrm{Sb}\left[\kappa^{-} C, N^{-1}-(\mathrm{CHhpp})-2-\left(\mathrm{CH}_{2} \mathrm{hppH}\right) \mathrm{C}_{6} \mathrm{H}_{4}\right] \mathrm{Cl}_{3}$

${ }^{1} \mathrm{H}$ NMR data was collected for the crystals for compound 16 . The NMR data could not be fully assigned as there were no straightforward upfield shifts in ligand resonances to show coordination to a metal like the compounds described in Chapter Two. It was therefore clear that the ligand had not coordinated in a bidentate manner as it did with $\mathrm{KN}\left\{\mathrm{SiMe}_{3}\right\}_{2}$ in Chapter Two. Due to the noisy nature of the ${ }^{1} \mathrm{H}$ NMR spectrum, a ${ }^{13} \mathrm{C}$ NMR spectrum was not collected as it would not aid in assigning the structure.

The ${ }^{1} \mathrm{H}$ NMR spectrum displays an aromatic region that had changed compared to that observed for the uncoordinated ligand in $\mathrm{CD}_{3} \mathrm{CN}$, from a broad singlet resonance at $7.23 \mathrm{ppm}$, to a collection of unassigned resonances between $7.50 \mathrm{ppm}$ and $6.94 \mathrm{ppm}$ in compound 16. Furthermore, in the hpp proton region of the spectrum the triplets had moved downfield and the quintets were not shifted. The region of spectrum where the 
methylene proton resonance was expected was more crowded than anticipated. There were three proton resonances in the methylene region of the spectrum instead of the anticipated one. These resonances occur at 4.95, 4.77 and $4.57 \mathrm{ppm}$. As uncoordinated 1,2-( $\left.\mathrm{CH}_{2} \mathrm{hpp}\right)_{2}-\mathrm{C}_{6} \mathrm{H}_{4}$ ligand has a methylene resonance of $4.57 \mathrm{ppm}$ in $\mathrm{CD}_{3} \mathrm{CN}$, it is highly likely that the 4.57 ppm peak indicates that uncoordinated ligand was still in solution. $\mathrm{As}_{\mathrm{SbCl}}$ has no protons, it cannot be seen if there is uncoordinated $\mathrm{SbCl}_{3}$ present, which would confirm whether or not coordination occurred as equimolar amounts of ligand and $\mathrm{SbCl}_{3}$ had been used. There were still the two other peaks in the methylene region of the ${ }^{1} \mathrm{H}$ NMR, this could be due to asymmetry in the coordination mode of the ligand if only one hpp group had coordinated to the $\mathrm{SbCl}_{3}$ and not the other, there would be a notable change in the chemical environment of one pair of methylene protons closest to the coordinating hpp group. Yet, the other methylene in the ligand would be too far from the coordinating hpp unit to experience a resonant change. If coordination by one hpp group had occurred in all of the coordinated ligand in solution, it would be expected that there would be a 1:1 integration ratio for the resonances at $4.95 \mathrm{ppm}$ and $4.77 \mathrm{ppm}$, as was observed.

In attempt to further characterise compound 16 all remaining compound 16 after NMR and crystallography data was obtained was sent to collect elemental analysis data, however this was not enough sample for the experimentation and time constraints prevented resynthesis of 16 . The crystal structure obtained of 16 (Figure 24) provided an insight on what was observed in the NMR data. 


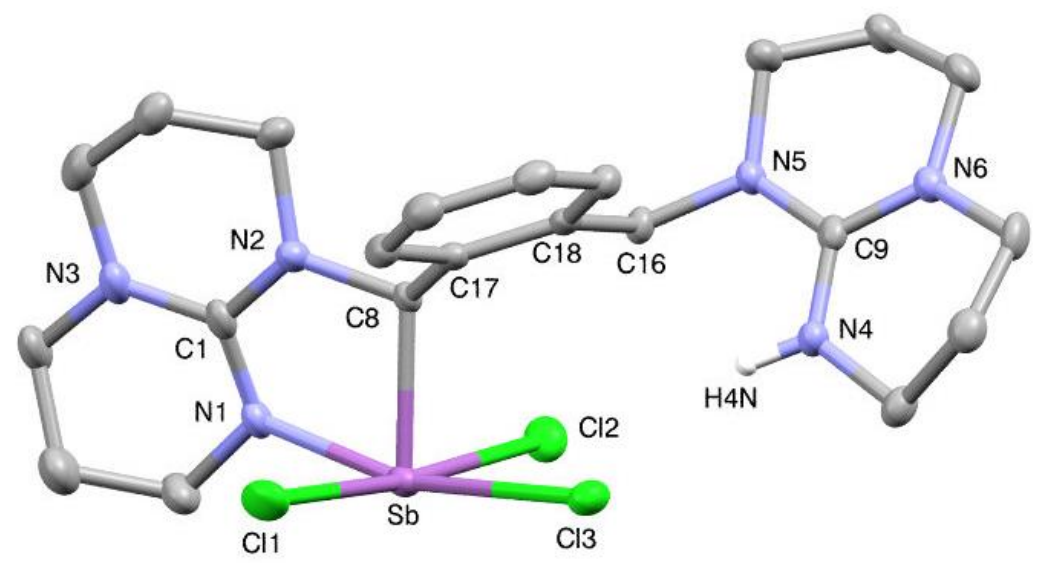

Figure 24: Thermal ellipsoid representation (50\%) of $\mathrm{Sb}\left[\kappa^{-} C, N^{-1} 1^{-(\mathrm{CHhpp})-2^{-}}\right.$ $\left.\left(\mathrm{CH}_{2} \mathrm{hppH}\right) \mathrm{C}_{6} \mathrm{H}_{4}\right] \mathrm{Cl}_{3}$. Selected bond lengths and angles have been reported in Tables 5 and 6 respectively. All hydrogen atoms except $\mathrm{H} 4 \mathrm{~N}$ have been omitted for clarity.

\begin{tabular}{|c|c|}
\hline Atoms of Bond & Bond Length (̊) \\
\hline $\mathrm{Sb} \mathrm{N}(1)$ & $2.183(4)$ \\
\hline $\mathrm{Sb} \mathrm{Cl}(1)$ & $2.5891(13)$ \\
\hline $\mathrm{Sb} \mathrm{Cl}(2)$ & $2.6779(12)$ \\
\hline $\mathrm{Sb} \mathrm{Cl}(3)$ & $2.7426(11)$ \\
\hline $\mathrm{Sb} \mathrm{C}(8)$ & $2.204(4)$ \\
\hline
\end{tabular}

Table 5: Selected bond lengths from compound 16 


\begin{tabular}{|c|c|}
\hline Atoms & Angle $\left.{ }^{\circ}\right)$ \\
\hline $\mathrm{Cl}(1) \mathrm{Sb} \mathrm{Cl}(3)$ & $92.99(4)$ \\
\hline $\mathrm{Cl}(2) \mathrm{Sb} \mathrm{Cl}(3)$ & $87.27(4)$ \\
\hline $\mathrm{Cl}(2) \mathrm{Sb} \mathrm{N}(1)$ & $93.85(11)$ \\
\hline $\mathrm{N}(1) \mathrm{Sb} \mathrm{Cl}(1)$ & $84.32(11)$ \\
\hline $\mathrm{C}(8) \mathrm{Sb} \mathrm{Cl}(1)$ & $89.99(12)$ \\
\hline $\mathrm{C}(8) \mathrm{Sb} \mathrm{Cl}(3)$ & $88.75(11)$ \\
\hline $\mathrm{C}(8) \mathrm{Sb} \mathrm{Cl}(2)$ & $84.32(12)$ \\
\hline $\mathrm{C}(8) \mathrm{Sb} \mathrm{N}(1)$ & $75.25(16)$ \\
\hline
\end{tabular}

Table 6: Selected bond angles for compound 16

Contrary to expectations, the crystal structure (Figure 24) shows the deprotonation of one of the $\mathrm{CH}_{2}$ hpp methylene groups (C8) and subsequent protonation of an imine nitrogen (N4). The ligand has coordinated to the antimony centre through $\mathrm{C} 8$ and the imine nitrogen of the neutral hpp unit (N1) in a bidentate coordination. As the hpp imine nitrogen (N1) has a lone pair, the bond to Sb, with a length of 2.183(3) $\AA$, is a dative bond. As expected, this bond length is shorter by approximately $0.65 \AA$ than those that occurred in aforementioned $\mathrm{KN}\left(\left\{\mathrm{SiMe}_{3}\right\}_{2}\right) \bullet 1,2-\left(\mathrm{CH}_{2} \mathrm{hpp}\right)_{2}-\mathrm{C}_{6} \mathrm{H}_{4}$. This is most likely because $\mathrm{Sb}^{3+}$ is smaller than $\mathrm{K}^{+}$by $0.62 \AA .^{72}$

Despite the fact that the protons on $\mathrm{C} 8$ are slightly acidic, it is worth noting that the cleavage of a $\mathrm{C}-\mathrm{H}$ bond is difficult to achieve and did not occur elsewhere during this project. However, a similar deprotonation has been reported by Coles et al. where a similar bis(guanidine) ligand $\mathrm{H}_{2} \mathrm{C}(\mathrm{hpp})_{2}$ (Figure 25) was deprotonated at its methylene position. However, this deprotonation occurred through the use of tert-butyllithium (tBuLi) ${ }^{73}$. 


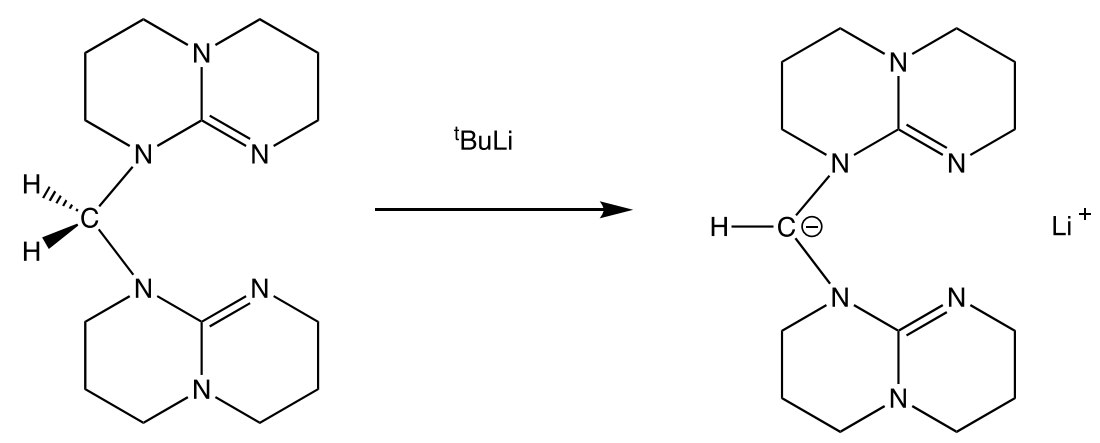

Figure 25: Deprotonation of $\mathrm{H}_{2} \mathrm{C}(\mathrm{hpp})_{2}$ using

${ }^{\mathrm{t}} \mathrm{BuLi}$

Although no studies have been performed to determine the mechanism of formation for this compound, it can be postulated that the source of the proton found on $\mathrm{N} 4$ was a result of an intramolecular proton transfer that occurred between $\mathrm{C} 8$ and $\mathrm{N} 4$. The carbon atoms in the methylene positions have slightly acidic protons due to the neighbouring electron withdrawing nitrogen atoms (N2 and N5 respectively). As the hpp-unit is strongly basic, it is possible that deprotonation occurred within the uncomplexed ligand prior to coordination (Scheme 19). This would have prevented ligand coordination to $\mathrm{SbCl}_{3}$ from occurring through both hpp groups as it does in $\mathrm{KN}\left\{\mathrm{SiMe}_{3}\right\}_{2} \bullet 1,2-\left(\mathrm{CH}_{2} \mathrm{hpp}\right)_{2}-\mathrm{C}_{6} \mathrm{H}_{4}$ as there would have been no lone pair on $\mathrm{N} 4$ to allow a dative bond to be formed from $\mathrm{N} 4$ to $\mathrm{Sb}$. 

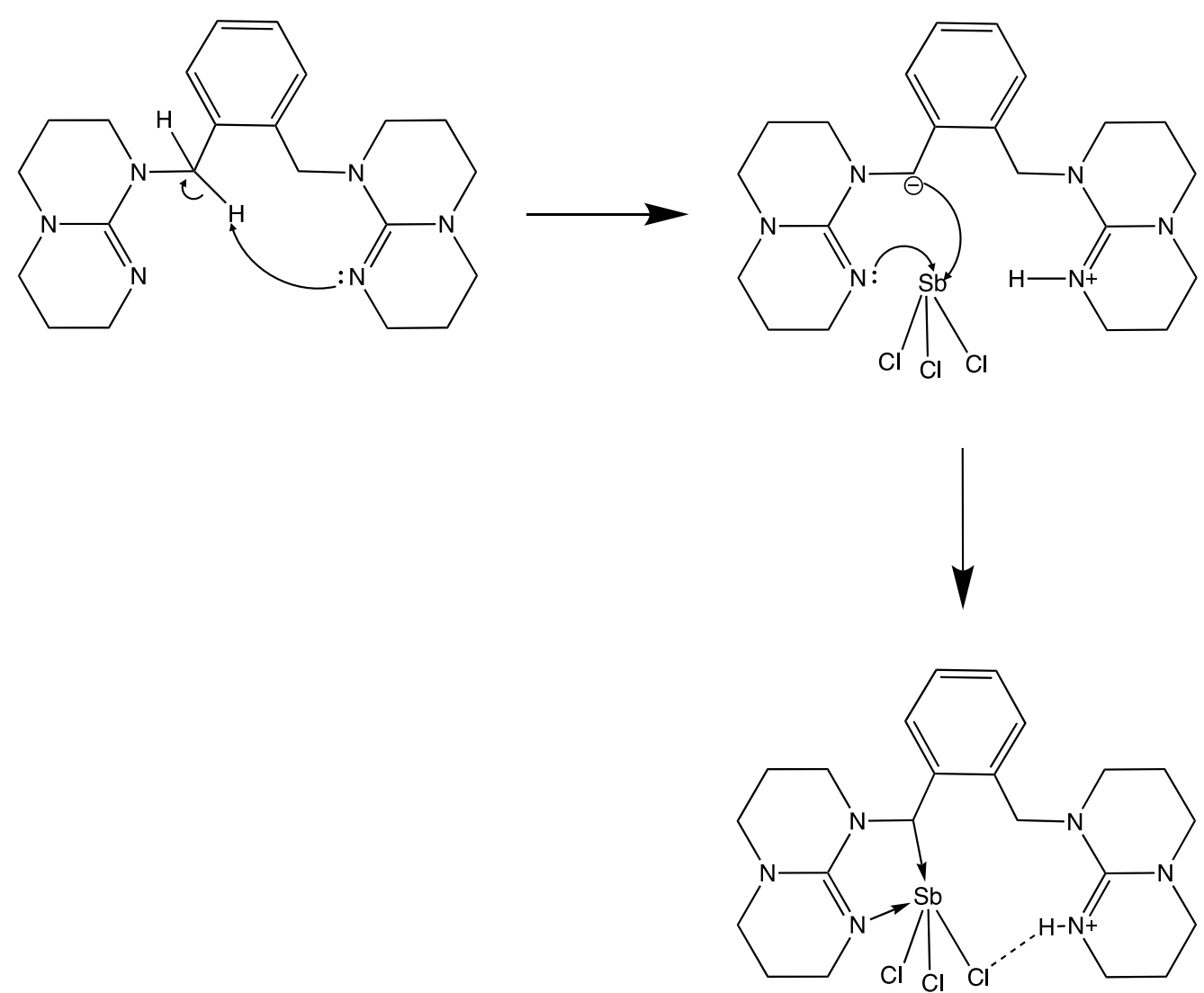

Scheme 19: Mechanism for the formation of compound 16 through the intramolecular protonation of the ligand before coordination to $\mathrm{SbCl}_{3}$.

This intramolecular deprotonation would have been enabled by the flexibility of the ligand, allowing the hpp groups to freely move because of the methylene linkers bridging between the aromatic ring and the hpp groups. However, it is unlikely this intramolecular deprotonation and consequent formation of a zwitterionic ligand would have happened for a large enough proportion of the ligand to react with $\mathrm{SbCl}_{3}$ to form crystals large enough for X-ray diffraction. This is because there is no resonance stabilisation of the negative charge in the uncomplexed ligand when intramolecular deprotonation has occurred.

However, there is a potential that an equilibrium may be set up between the two forms of the ligand (Figure 26). If this is case, only the zwitterionic ligand coordinates to $\mathrm{SbCl}_{3}$ and as this coordination occurs, the equilibrium will be forced in the forwards direction to provide more of the zwitterionic ligand. 


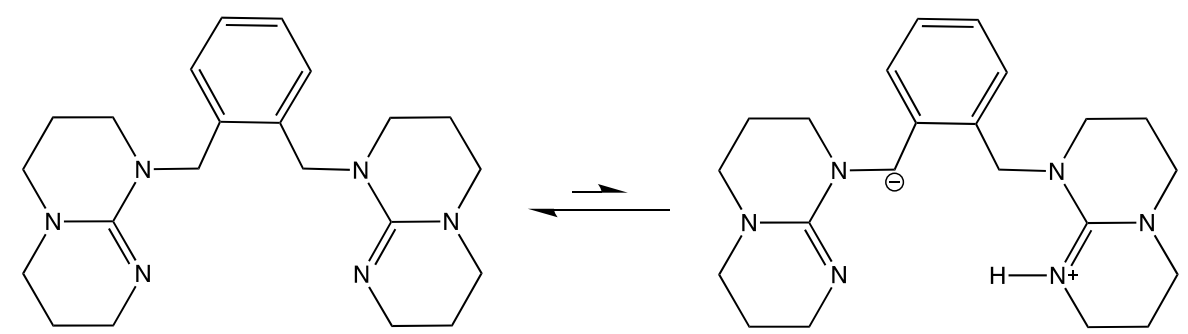

Figure 26: Potential equilibrium between the neutral and zwitterionic forms of $1,2-\left(\mathrm{CH}_{2} \mathrm{hpp}\right)_{2}-\mathrm{C}_{6} \mathrm{H}_{4}$

Alternatively, the intramolecular protonation could have occurred after the coordination of 1,2-( $\left.\mathrm{CH}_{2} \mathrm{hpp}\right)_{2}-\mathrm{C}_{6} \mathrm{H}_{4}$ to $\mathrm{SbCl}_{3}$ through N1 (Scheme 20). N4 on the non-coordinating hpp unit could be protonated via an acidic proton of the $\mathrm{C} 8$ methylene. The newly formed carbanion and its close proximity to antimony due to the existing coordination through N1 would allow an opportunity for $\mathrm{C} 8$ to act as a Lewis base and form a bond from $\mathrm{C} 8$ to $\mathrm{Sb}$.

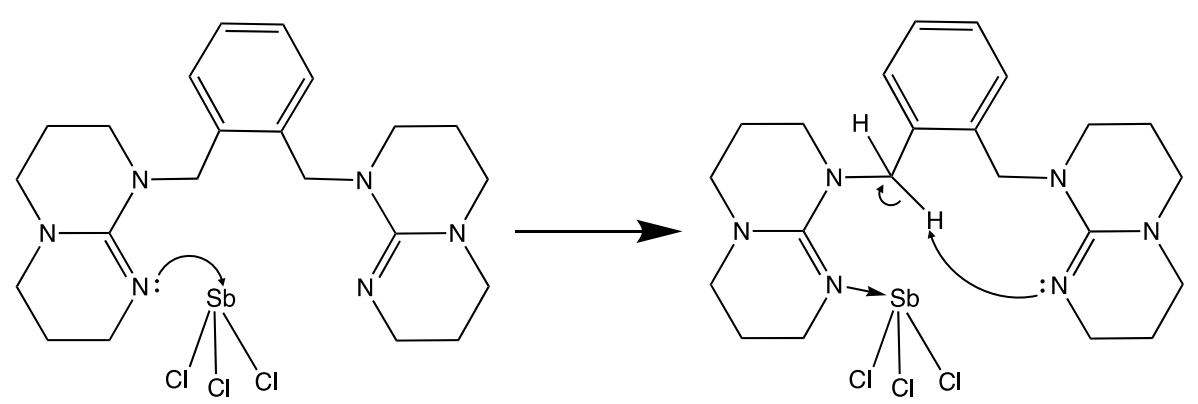

$$
\downarrow
$$

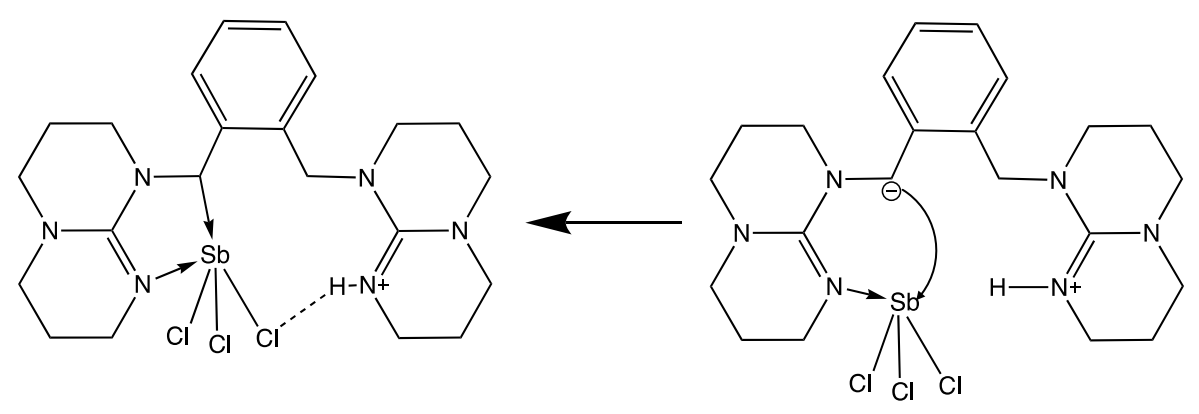

Scheme 20: Mechanism for the formation of compound 16 through the intramolecular protonation of the ligand after coordination to $\mathrm{SbCl}_{3}$. 
The proton transfer in question is an anomaly in this project. The heating of the compound (to solubilise it enough in $\mathrm{CD}_{3} \mathrm{CN}$ to obtain NMR data) could have provided sufficient energy to activate a proton transfer process. Therefore, a small experiment involving the heating of $1,2^{-}\left(\mathrm{CH}_{2} \mathrm{hpp}\right)_{2}-\mathrm{C}_{6} \mathrm{H}_{4}$ in $\mathrm{CD}_{3} \mathrm{CN}$ was conducted to see whether the intramolecular protonation could occur without the presence of antimony. The ${ }^{1} \mathrm{H}$ NMR spectrum before heating was identical to that after heating for three days at $60^{\circ} \mathrm{C}$, this is evidence that the intramolecular protonation observed in compound 16 required $\mathrm{SbCl}_{3}$.

The proton transferred from $\mathrm{C} 8$ to $\mathrm{N} 4$ appears to be interacting with the chloride Cl3. The interaction of $\mathrm{Cl} 3$ with the proton bonded to N4 is supported by the lengthening of the $\mathrm{Sb}-\mathrm{Cl} 3$ bond to 2.726 (11) $\AA$ in comparison with the Sb-Cl1 and Sb-Cl2 bond lengths of 2.5891 (13) $\AA$ and 2.6779 (12) A, respectively. The longer bond from $\mathrm{Sb}-\mathrm{Cl} 3$ is indicative of a weaker bond which is occurring because the electron density of the chloride is also involved in the bond with the proton on N4. This lengthening of the $\mathrm{Sb}-\mathrm{Cl} 3$ bond could also be a result of the trans-influence, whereby N1 is donating electron density to antimony, which therefore weakens the $\mathrm{Cl} 3$ bond trans to N1.

The $\mathrm{H}^{---} \mathrm{Cl}$ interaction has a distance of $2.462 \AA$. This is much longer than the typical $\mathrm{H}-\mathrm{Cl}$ bond length of $1.28 \AA,^{74}$ supporting that $\mathrm{Cl} 3$ is still bonded to the antimony. Similar values were reported for a structure published by Bujak which also showed $\mathrm{N}-\mathrm{H}---\mathrm{Cl}-\mathrm{Sb}$ interactions. $\mathrm{H}---\mathrm{Cl}$ distances were

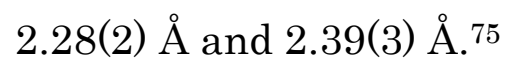

By using VSEPR theory, uncomplexed antimony trichloride should exist in an approximately trigonal pyramidal shape. Upon coordination of the ligand, $\mathrm{SbCl}_{3}$ has expanded its octet and transformed into a square based pyramid where the basal plane is defined by Cl1, Cl2, Cl3, and N1 (Figure 27). The angles in the crystal structure between atoms of the basal plane support this, all being close to $90^{\circ}$ (Table 6 ). These angles add up to $358.42^{\circ}$ 
which shows there is only slight distortion through the bottom plane of the square based pyramid. The angles from $\mathrm{C} 8$ to the bottom plane of the shape are also close to $90^{\circ}$ (Table 6). Therefore, the lone pair on the antimony must be sitting opposite the $\mathrm{Sb}-\mathrm{C} 8$ bond.

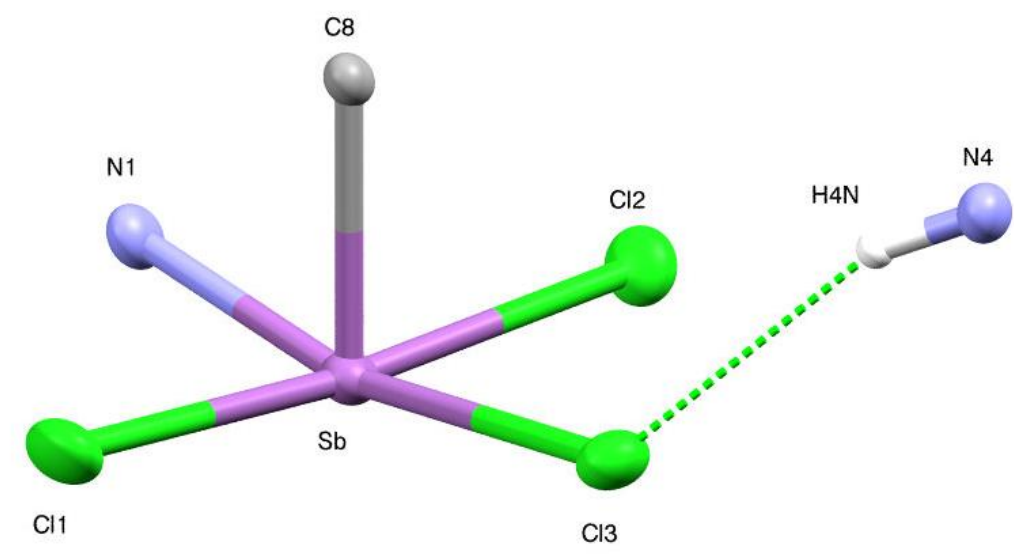

Figure 27: Thermal ellipsoid (50\%) of section of $\mathrm{Sb}^{-} \kappa^{-} C, N{ }^{-1}-(\mathrm{CHhpp})-$ 2 - $\left.\left(\mathrm{CH}_{2} \mathrm{hppH}\right) \mathrm{C}_{6} \mathrm{H}_{4}\right] \mathrm{Cl}_{3}$ showing the square based pyramid section of the crystal structure.

The smaller size of $\mathrm{Sb}^{3+}(0.9 \AA)$ as compared to $\mathrm{K}^{+}(1.52 \AA) 68$ could have prevented the $1,2^{-}\left(\mathrm{CH}_{2} \mathrm{hpp}\right)_{2}-\mathrm{C}_{6} \mathrm{H}_{4}$ coordinating to $\mathrm{SbCl}_{3}$ in the same way as it did to $\mathrm{KN}\left(\left\{\mathrm{SiMe}_{3}\right\}_{2}\right)$. This is because for the ligand to coordinate to $\mathrm{SbCl}_{3}$ through both hpp groups, they would have to be closer together than for the potassium complex and the steric strain on the ligand may have been too much.

The bond angle at the methylene group on the coordinating side of the ligand (N2-C8-C17) is $110.8(4)^{\circ}$. This is narrower than the $\mathrm{N}^{-}-\mathrm{C} 16-\mathrm{C} 18$ bond angle of $114.6(4)^{\circ}$. This is because the $\mathrm{SbCl}_{3}$ coordinating to both the hpp nitrogen and the methylene carbon forces the hpp group closer to the arene group. However, the antimony is positioned too far away from the arene group to have any $\pi$-interactions. Furthermore, the lone pair is 
generally required to be facing the arene group for an antimony-arene $\pi^{-}$ interaction. 69

A crystal structure with similar characteristics to that of compound 16 was obtained by Coles et al. in which an [hpp]- unit was coordinated to $\mathrm{SbCl}_{3}$ through both imine nitrogens (Figure 28). ${ }^{76}$ Two of the chloride ligands on the antimony were interacting with the protons on an $\left.[\mathrm{hppH}]_{2}\right]^{+}$unit. The average $\mathrm{Sb}-\mathrm{N}$ bond length in this structure is $2.1679 \AA$ which is very similar to the $\mathrm{Sb}-\mathrm{N} 1$ bond length of 2.183 (4) in compound 16. Furthermore, the average $\mathrm{Sb}-\mathrm{Cl}$ bond length for the two chlorides that are interacting with a proton on the $\mathrm{hppH}_{2}{ }^{+}$unit was $2.5919 \AA$, which is slightly less than that of the Sb-Cl3 bond length 2.7426 (11) in compound 16.

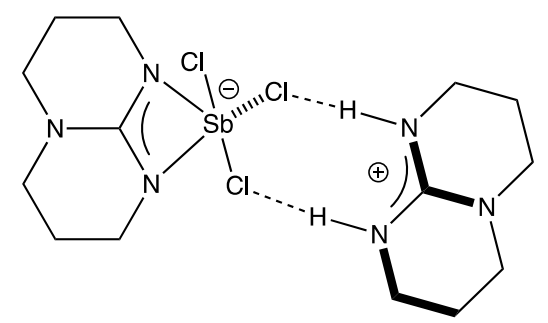

Figure 28: $\left[\mathrm{hppH} \mathrm{H}_{2}\right]\left[\mathrm{Sb}(\mathrm{hpp}) \mathrm{Cl}_{3}\right]$

\section{Synthesis and Characterisation of $\mathrm{SbCl}_{3} \bullet 1,3-\left(\mathrm{CH}_{2} \mathrm{hpp}\right)_{2}-\mathrm{C}_{6} \mathrm{H}_{4}$}

An attempt to coordinate $1,3-\left(\mathrm{CH}_{2} \mathrm{hpp}\right)_{2}-\mathrm{C}_{6} \mathrm{H}_{4}$ to $\mathrm{SbCl}_{3}$ was conducted to determine what effect a ligand with a different substitution pattern around the benzene ring would have on the coordination. The coordination of 1,3$\left(\mathrm{CH}_{2} \mathrm{hpp}\right)_{2}-\mathrm{C}_{6} \mathrm{H}_{4}$ to $\mathrm{SbCl}_{3}$ could have occurred in a bidentate manner through both of the hpp groups, or through one of the hpp groups as seen with compound 16. Alternatively, a polymer could be synthesised, like that formed during the synthetic attempt of $\mathrm{KN}\left\{\mathrm{SiMe}_{3}\right\}_{2} \bullet 1,3-\left(\mathrm{CH}_{2} \mathrm{hpp}\right)_{2}-\mathrm{C}_{6} \mathrm{H}_{4}$. 


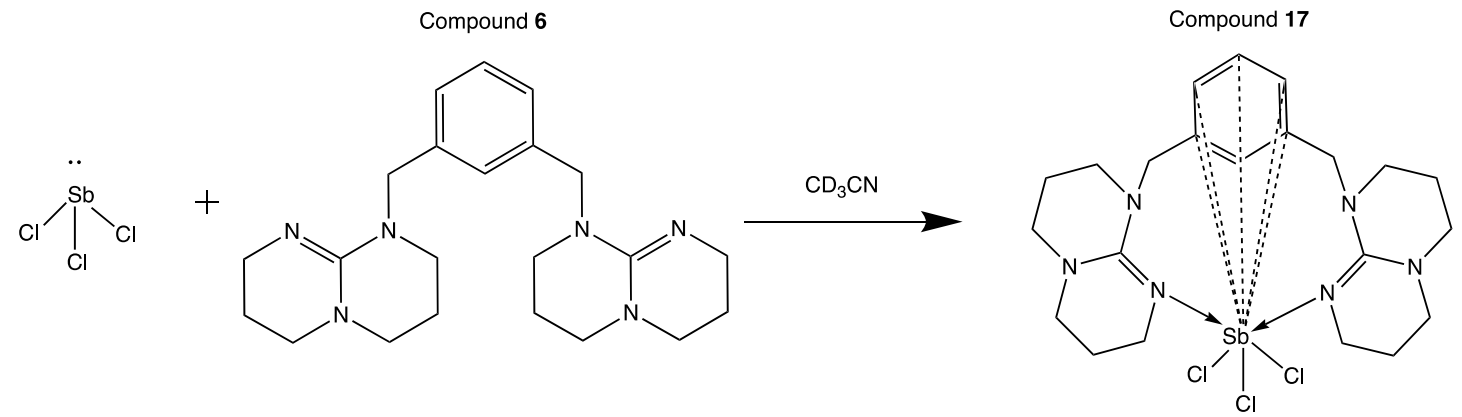

Scheme 21: Attempted Coordination of $1,3-\left(\mathrm{CH}_{2} \mathrm{hpp}\right)_{2}-\mathrm{C}_{6} \mathrm{H}_{4}$ to $\mathrm{SbCl}_{3}$

This coordination was attempted on an NMR scale using $\mathrm{CD}_{3} \mathrm{CN}$ (Scheme 21). The ligand was dissolved in $\mathrm{CD}_{3} \mathrm{CN}$ and the slightly yellow solution was added to $\mathrm{SbCl}_{3}$ in a vial. A sticky precipitate formed immediately that was heated to redissolve before the reaction was reintroduced to the NMR tube for ${ }^{1} \mathrm{H}$ NMR analysis. Crystallisation attempts were unsuccessful.

Analysis of the ${ }^{1} \mathrm{H}$ NMR data in comparison to that of the uncomplexed ligand displayed resonance shifts in the ligand peaks. Notably, there was a peak shift from $4.56 \mathrm{ppm}$ to $4.76 \mathrm{ppm}$ associated with the methylene protons. There were also shifts for the peaks assigned to aromatic and hpp protons. Therefore, the ${ }^{1} \mathrm{H}$ NMR analysis indicated the coordination of 1,3$\left(\mathrm{CH}_{2} \mathrm{hpp}\right)_{2}-\mathrm{C}_{6} \mathrm{H}_{4}$ ligand to $\mathrm{SbCl}_{3}$ may have successfully occurred. The NMR data shows no sign of ligand asymmetry, unlike that observed in the NMR data of compound 16. This is important as it shows that intramolecular deprotonation of a methylene carbon has not occurred as it did in the synthesis of compound 16. As the same $\mathrm{SbCl}_{3}$ metal salt has been used for these two analogous reactions, it is likely that the deprotonation behaviour in compound 16 is specific to $1,2-\left(\mathrm{CH}_{2} \mathrm{hpp}\right)_{2}-\mathrm{C}_{6} \mathrm{H}_{4}$ and is not likely to occur in $1,3-\left(\mathrm{CH}_{2} \mathrm{hpp}\right)_{2}-\mathrm{C}_{6} \mathrm{H}_{4}$ due to the proximity differences from the substitution pattern of hpp groups around the aromatic group in the ligand. 


\section{Summary and Conclusions}

This section of the research gave an unexpected and very interesting result. Although no pnictogen-arene interactions were observed, the results did reinforce that a large metal with space around it is required for coordination of 1,2-( $\left(\mathrm{CH}_{2} \mathrm{hpp}\right)_{2}-\mathrm{C}_{6} \mathrm{H}_{4}$. The non-innocent behaviour of the ligand was demonstrated with the isolation of compound 16, which formed via $\mathrm{C}-\mathrm{H}$ activation of one of the bridging methylene groups. 


\section{Chapter Four}

\section{$\mathrm{N}$-phosphino guanidines}

\section{Introduction}

As a side project from the main arene-hpp chemistry of this thesis, efforts were made to coordinate a different ligand, in which arene interactions were replaced by a different potential bonding site. An N-phosphino guanidine was chosen as a ligand for this purpose, which consists of a guanidine functionality and a phosphine group. The two components of the ligands are bonded together with an N-P bond. An N-phosphino guanidine ligand was employed in this research due to the potential to coordinate through both its available nitrogen and phosphorus atoms (Scheme 22). N-phosphino guanidines were therefore only used as $\sigma$ donors through the nitrogen and/or phosphorus without attempts at $\pi$ donation through an arene group.<smiles>[R]N=C(N([R])[R])N([R])[PbH]([R])[Na]</smiles>

Scheme 22: An N-phosphino guanidine with $\mathrm{P}, \mathrm{N}$ coordination to a metal

This part of the thesis served as an attempt to compare the coordination modes of a guanindine with an arene group as discussed in Chapters Two and Three with a guanidine with a phosphine group (Figure 29). A phosphine coordination to a metal is a $\sigma$-interaction which is stronger than a $\pi$-interaction, therefore a bidentate coordination of an N-phosphino guanidine should be favoured. 

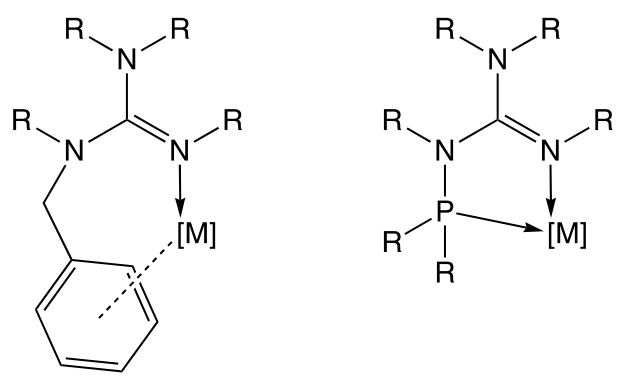

Figure 29: Left: An arene guanidine coordinating to a metal Right: An N-phosphino guanidine coordinating to a metal

The exploration into phosphine chemistry in this project is also relevant because ruthenium is a large, soft metal so it should form strong $\sigma$ interactions with phosphorus, as the $3 p$ orbitals of phosphorus are bigger than the $2 \mathrm{p}$ orbitals of the nitrogen (so are more available for donation) ${ }^{60}$

Hpp containing $\mathrm{N}$-phosphino guanidines were first synthesised to be used as ligands for coordination to $\mathrm{Ni}$ (II) centres for the initiation of ethylene oligomerisation. ${ }^{77}$ This chapter of research used the $\mathrm{PPh}_{2}(\mathrm{hpp})$ (7(diphenylphosphino)-1,5,7-triazabicyclo[4.4.0]dec-5-ene) ligand (Figure 30) that was coordinated to $\mathrm{Ni}$ (II) in a high yielding synthesis by Dyer et al. (Figure 30). This is the only published example of the coordination of this ligand, synthesised by displacement of DME (1,2-dimethoxyethane) from the $\mathrm{NiBr}_{2}(\mathrm{DME})$ starting material.<smiles>c1ccc([Pb](c2ccccc2)N2CCCN3CCCN=C32)cc1</smiles><smiles>c1ccc([Pb]2(c3ccccc3)N3CCCN4CCCN2C43)cc1</smiles>

Figure 30: Left: $\mathrm{PPh}_{2}(\mathrm{hpp})$ Right: $\mathrm{NiBr}_{2} \bullet \mathrm{PPh}_{2}(\mathrm{hpp})$ 


\section{Modified Synthesis of $\mathrm{PPh}_{2}(\mathrm{hpp})$}

An attempt to synthesise $\mathrm{PPh}_{2}(\mathrm{hpp}$ ) (compound 18) was conducted using the method reported by Dyer et al. However, the synthesis was low yielding (32\%) and the ${ }^{1} \mathrm{H}$ NMR spectrum revealed the presence of hppH impurities in the product. The occurrence of $\mathrm{hppH}$ impurities was taken as evidence that the deprotonation step of the synthesis was not going to completion. The widely available reagent, $\mathrm{n}-\mathrm{BuLi}$ had been employed in the first step of this synthesis, to deprotonate hppH. If the $\mathrm{n}-\mathrm{BuLi}$ solution available in the laboratory had a lower concentration than labelled or was impure, there would be insufficient $\mathrm{n}-\mathrm{BuLi}$ to deprotonate all the $\mathrm{hppH}$ in the reaction vessel. To test this hypothesis, freshly purchased $\mathrm{NaH}$ was used as an alternative base to $\mathrm{n}$-BuLi. Consequently, this change in reagent resulted in an improved (83.6\%) yield of $\mathrm{PPh}_{2}$ hpp (Scheme 23) with no indication of an hppH impurity in the ${ }^{1} \mathrm{H}$ NMR spectrum. This modified synthesis is higher yielding than reported by Dyer et al. 77 where a $78 \%$ yield was obtained.

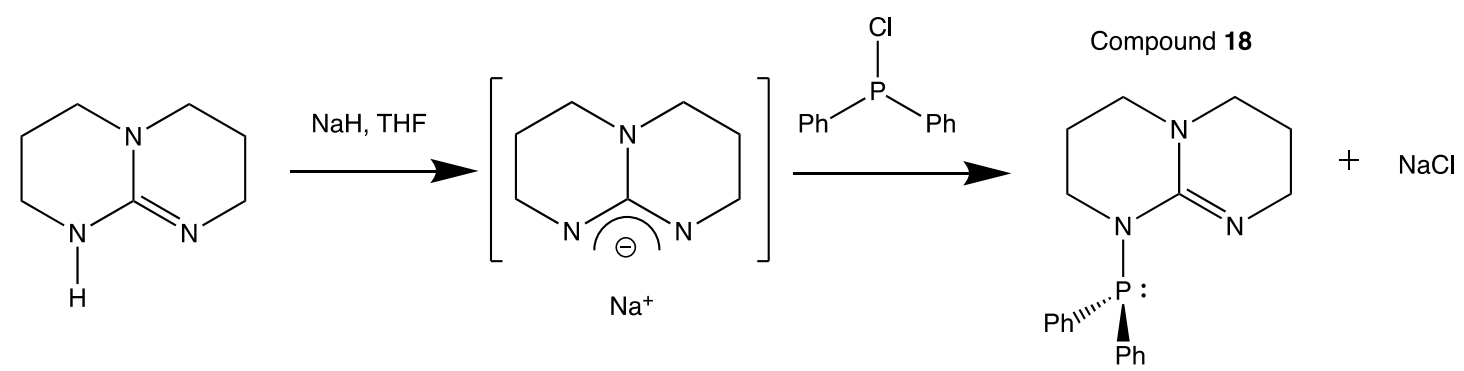

Scheme 23: Modified Synthesis of $\mathrm{PPh}_{2}(\mathrm{hpp})$

$\mathrm{PPh}_{2}(\mathrm{hpp})$ coordination attempts started with $\mathrm{KN}\left\{\mathrm{SiMe}_{3}\right\}_{2}$ and $\mathrm{LiN}\left\{\mathrm{SiMe}_{3}\right\}_{2}$ metal salts. These reagents were chosen because of the concurrent syntheses using group one metal salts (see Chapter Two). Any successes in the coordination of $\mathrm{PPh}_{2}(\mathrm{hpp})$ would allow for a comparison in the 
coordination modes of the $\mathrm{PPh}_{2}(\mathrm{hpp})$ ligand to the other ligands described in this thesis.

\section{Attempted Synthesis and Characterisation of $\mathrm{KN}\left\{\mathrm{SiMe}_{3}\right\}_{2} \bullet \mathrm{PPh}_{2}(\mathrm{hpp})$}

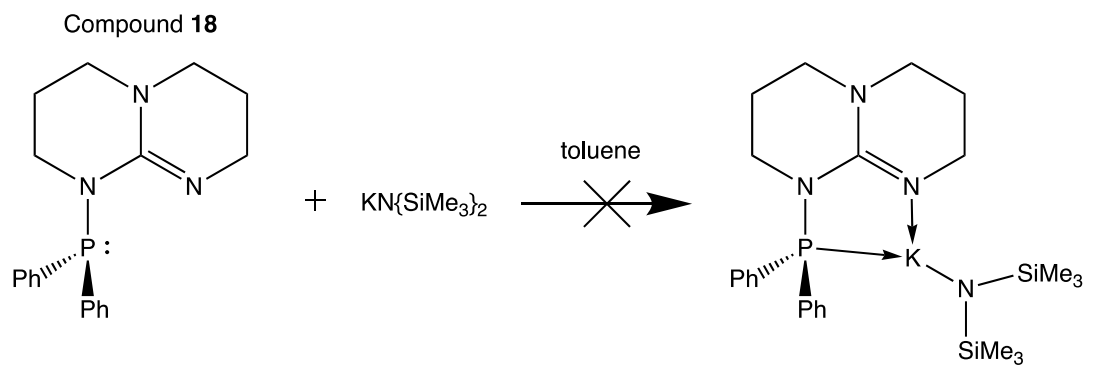

Scheme 24: Attempted synthesis of $\mathrm{KN}\left\{\mathrm{SiMe}_{3}\right\}_{2} \bullet \mathrm{PPh}_{2}(\mathrm{hpp})$

The coordination of $\mathrm{PPh}_{2}(\mathrm{hpp})$ to $\mathrm{KN}\left\{\mathrm{SiMe}_{3}\right\}_{2}$ was initially attempted on an NMR scale to test whether it would be a viable synthesis. The reaction was performed in $\mathrm{CD}_{3} \mathrm{CN}$ which is a polar, readily available NMR solvent for air and water sensitive compounds. $\mathrm{KN}\left\{\mathrm{SiMe}_{3}\right\}_{2}$ and $\mathrm{PPh}_{2}(\mathrm{hpp})$ were dissolved separately in $\mathrm{CD}_{3} \mathrm{CN}$. Upon the addition of the $\mathrm{PPh}_{2}(\mathrm{hpp})$ solution to the $\mathrm{KN}\left\{\mathrm{SiMe}_{3}\right\}_{2}$ solution, a colour change from colourless to yellow was observed. No crystallisation occurred from this NMR scale synthesis, so the synthesis was scaled up, using $100 \mathrm{mg}$ of the ligand and THF as the solvent. THF was used as the solvent for synthesis as acetonitrile cannot be used in large amounts in the glovebox as it damages the catalyst bed. The solution turned rapidly brown and slow evaporation of the THF did not result in any crystalline material, only an oily precipitate. The colour changed to brown and the resultant poorly defined product indicated a potential decomposition had occurred. To test whether this decomposition was a result of using the coordinating solvent THF, which may bind more strongly to potassium than $\mathrm{PPh}_{2}(\mathrm{hpp})$, the reaction was repeated using the noncoordinating solvent toluene (Scheme 24). In the repeat reaction in toluene it was promising to see that the solution turned yellow, as with the NMR scale reaction and not brown as with the reaction in THF. In an attempt to 
crystallise the compound, the vial in which the coordination took place was left with the lid cracked open for slow evaporation of the toluene. Crystallisation occurred after two months yielding crystals suitable for $\mathrm{X}^{-}$ ray diffraction. Most of the toluene had evaporated off by the time crystallisation was observed. ${ }^{1} \mathrm{H}$ and ${ }^{13} \mathrm{C}$ NMR data was collected for the dried crystalline solid.

The ${ }^{1} \mathrm{H}$ and ${ }^{13} \mathrm{C}$ NMR data obtained for the product of the reaction was complicated and a full assignment could not be completed. However, notable features of the ${ }^{1} \mathrm{H}$ NMR include the presence of a large number of aromatic resonances spanning 7.85 to $6.75 \mathrm{ppm}$. There are also numerous peaks in the region where hpp protons are expected. If coordination had occurred as shown in Scheme 3, the ${ }^{1} \mathrm{H}$ NMR spectrum is predicted to show 6 -multiplets from the protons of the hpp bicyclic ring structure as this is what is observed in the ${ }^{1} \mathrm{H}$ NMR spectrum of the uncomplexed ligand (compound 18). This pattern is still to be expected for the complex, only shifted due to the coordination to an electropositive metal. The protons of $\mathrm{KN}\left\{\mathrm{SiMe}_{3}\right\}_{2}$ have a chemical shift of $0.14 \mathrm{ppm}$ in $\mathrm{C}_{6} \mathrm{D}_{6}$. There were no peaks at $0.14 \mathrm{ppm}$ in the ${ }^{1} \mathrm{H}$ NMR spectrum, however, there are numerous peaks nearby in the spectrum. This indicates multiple environments for the $\mathrm{N}\left\{\mathrm{SiMe}_{3}\right\}_{2^{-}}$groups.

Due to the complicated ${ }^{1} \mathrm{H}$ and ${ }^{13} \mathrm{C}$ NMR spectra obtained, ${ }^{31} \mathrm{P}$ NMR data was not collected for the compound synthesised as it would not aid in the characterisation of the compound. From the analysis of the NMR data, it can be concluded that a reaction has occurred as the spectrum is not the same as that of the starting materials. However, the coordination expected from the synthesis (as shown in Scheme 24) has not been achieved. As the NMR data was inconclusive in determining what reaction took place, X-ray diffraction data was collected on the prepared crystals.

The crystal structure obtained (Figure 31) showed that a cluster compound consisting of 10 potassium atoms surrounded by 8 coordinating [hpp]- 
ligands was synthesised (compound 19). Two anions or a component of the structure with a -2 charge to balance the charge of the $\left[\mathrm{K}_{10}(\mathrm{hpp})_{8}\right]^{2+}$ cluster could not be identified from the X-ray diffraction experiment. As the identity of the anions has not been solved, they have been omitted from Figure 31 for clarity. Furthermore, as the crystal structure could not be fully solved, the images in Figure 31 are to be used for illustrative purposes only therefore a discussion of the bond lengths found in the structure has not been included.

The first point to note is the ' $\mathrm{PPh}_{2}$ ' group (from the $\mathrm{PPh}_{2}(\mathrm{hpp}$ ) ligand) is not present in this crystal structure. Therefore, the $\mathrm{PPh}_{2} \mathrm{hpp}$ ligand has been

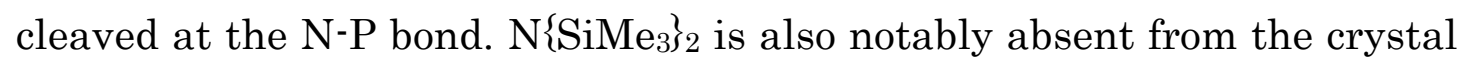
structure. All bonds to potassium atoms of the structure are K-N bonds. K2 is not bonded to any atoms because it inhabits the centre of the cage. $\mathrm{K} 3$ is four coordinate and $\mathrm{K} 1$ and $\mathrm{K} 4$ are five coordinate potassium atoms. Due to the complexity of the crystal structure, Figure 31 represents three viewpoints of the structure to give a clearer depiction of the arrangement of the atoms in the compound synthesised. Figure 32 shows the potassium atoms of the $\left[\mathrm{K}_{10}(\mathrm{hpp})_{8}\right]^{2+}$ cluster bonded together. These pseudo bonds have been included to depict the shape of the cluster. The mechanism for formation of this compound is unknown. 

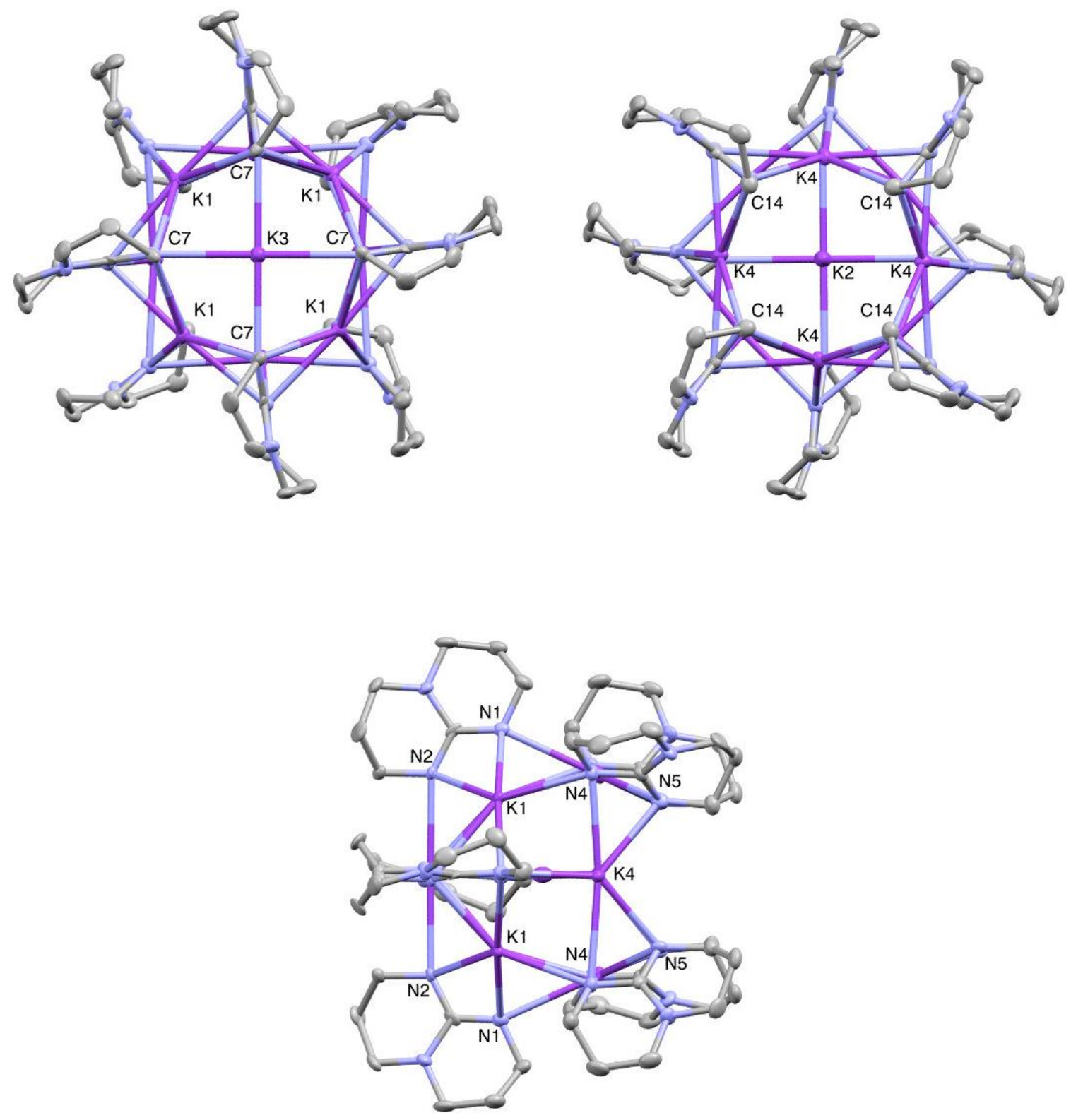

Figure 31: Thermal ellipsoid (50\%) for compound 19 from three viewpoints. All hydrogen atoms have been omitted for clarity. 


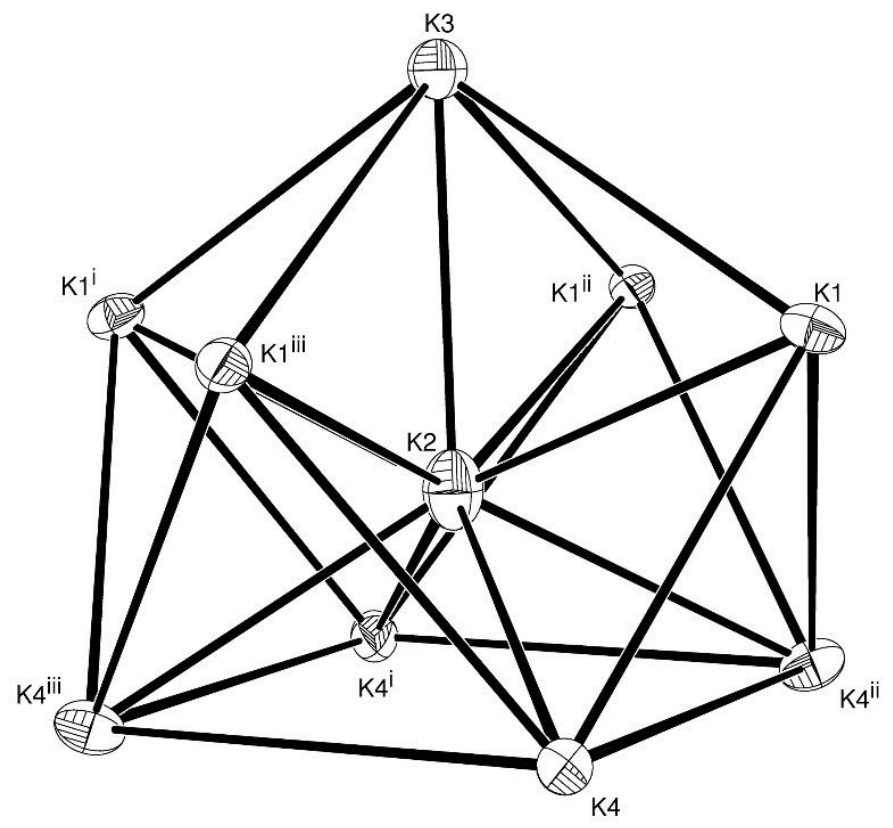

Figure 32: The potassium atoms of $\left[\mathrm{K}_{10}(\mathrm{hpp})_{8}\right]^{2+}$

A closely related lithium cluster core, $\left[\mathrm{Li}_{8}(\mathrm{hpp})_{6}\right]^{2+}$ (with two $\left[\mathrm{Li}\left(\mathrm{Me}_{2} \mathrm{Al} t \mathrm{Bu}_{2}\right)_{2}\right]^{-}$counterions), was synthesised by Wheatley et al.78 This structure has only $8 \mathrm{Li}^{+}$and 6 [hpp]-ions as opposed to the $10 \mathrm{~K}^{+}$and 8 [hpp]- in the $\left[\mathrm{K}_{10}(\mathrm{hpp})_{8}\right]^{2+}$ cluster (compound 19). The average $\mathrm{Li}-\mathrm{N}$ bond length in $\left[\mathrm{Li}_{8}(\mathrm{hpp})_{6}\right]^{2+}$ was $1.987 \AA$. This is shorter than the average K-N bond length in $\left[\mathrm{K}_{10}(\mathrm{hpp})_{8}\right]^{2+}$ of $2.859 \AA$. The longer bond $\mathrm{K}-\mathrm{N}$ bond lengths for the potassium cluster can be attributed to the larger size of potassium.

As previously mentioned, the presence of multiple $\mathrm{N}\left\{\mathrm{SiMe}_{3}\right\}_{2^{-}}$and phenyl proton peaks in the ${ }^{1} \mathrm{H}$ NMR shows that there are different $\mathrm{N}\left\{\mathrm{SiMe}_{3}\right\}_{2}{ }^{-}$and phenyl environments. However, as there is no sign of $\mathrm{N}\left\{\mathrm{SiMe}_{3}\right\}_{2}-$ or phenyl groups in the crystal structure itself, it is likely that there are different byproducts contaminating the crystals that were included in the NMR sample, this would have occurred as the toluene evaporated almost to dryness so impurities from the starting materials would have become incorporated in the crystalline material. These crystals were not washed as due to the length of time it took to crystallise the compound in the first place, and there 
was not sufficient time to recrystallise the compound to obtain clean NMR data.

\section{Attempted Synthesis of $\left[\mathrm{K} \bullet \mathrm{PPh}_{2}(\mathrm{hpp})\right]\left[\mathrm{BPh}_{4}\right]$}

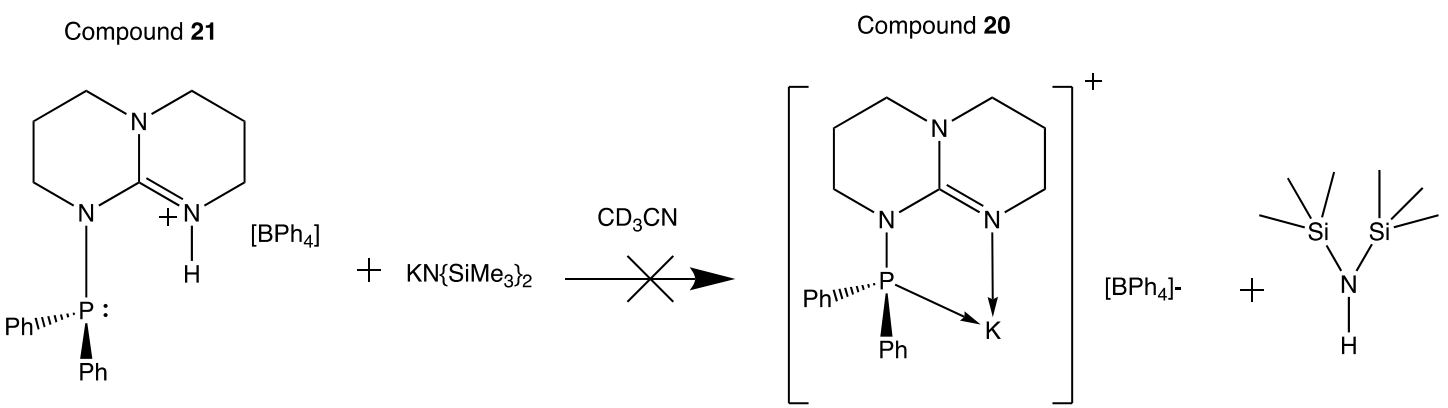

Scheme 25: Attempted Synthesis of $\left[\mathrm{K} \bullet \mathrm{PPh}_{2}(\mathrm{hpp})\right]\left[\mathrm{BPh}_{4}\right]$

Upon the failure to coordinate $\mathrm{PPh}_{2}(\mathrm{hpp})$ to a potassium metal centre, a new method was tried to achieve the coordination. This method firstly required the synthesis of the protonated $\mathrm{PPh}_{2}(\mathrm{hpp})$ ligand by reacting the neutral ligand with $\left[\mathrm{HNEt}_{3}\right]\left[\mathrm{BPh}_{4}\right]$. This reagent was freshly prepared by mixing $\mathrm{HNEt}_{3} \mathrm{Cl}$ with $\mathrm{NaBPh}_{4}$ in water and filtering off the $\mathrm{NaCl}$ solution. [HNEt $]$ [ $\left.\mathrm{BPh}_{4}\right]$ is a Brønsted acid (for protonation purposes) and provides tetraphenylborate $\left(\mathrm{BPh}_{4}\right)$ as a negative counterion for the positive ligand that is synthesised.

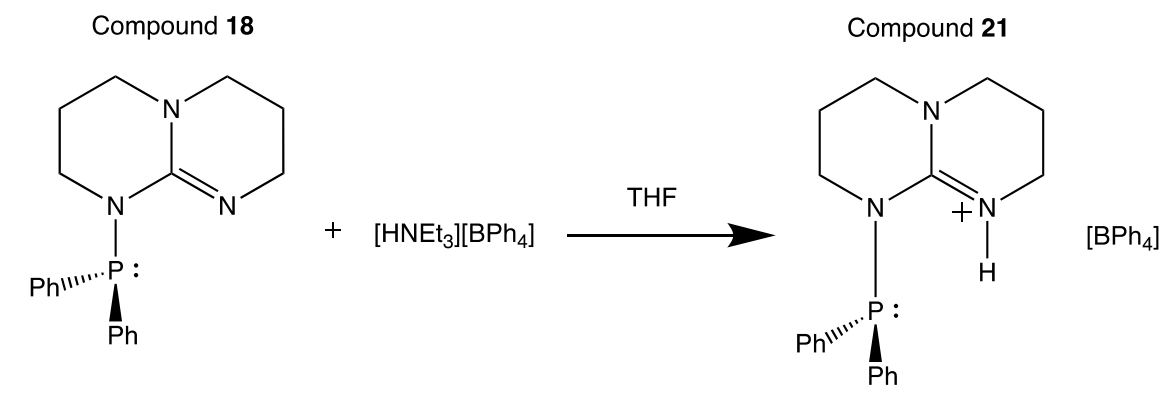

Scheme 26: Synthesis of $\left[\mathrm{PPh}_{2} \mathrm{hppH}\right]\left[\mathrm{BPh}_{4}\right]$ 
Once $\left[\mathrm{PPh}_{2} \mathrm{hppH}\right]\left[\mathrm{BPh}_{4}\right]$ had been synthesised (Scheme 26), the reaction with $\mathrm{KN}\left\{\mathrm{SiMe}_{3}\right\}_{2}$ (Scheme 25) could be attempted.

This reaction (Scheme 25) was attempted on an NMR scale. Both $\left[\mathrm{PPh}_{2} \mathrm{hppH}\right]\left[\mathrm{BPh}_{4}\right]$ and $\mathrm{KN}\left\{\mathrm{SiMe}_{3}\right\}_{2}$ were soluble in $\mathrm{CD}_{3} \mathrm{CN}$ but once combined, a pale yellow precipitate formed which could not be dissolved, even upon heating. Because of the product's insolubility, neither NMR nor crystallography data could be obtained. The solubility issues could indicate that a polymeric chain or a charged species may have been synthesised.

\section{Attempted Synthesis and Characterisation of $\operatorname{LiN}\left\{\mathrm{SiMe}_{3}\right\}_{2} \bullet \mathrm{PPh}_{2}(\mathrm{hpp})$}

To examine whether the cleavage of the N-P bond in the synthesis of compound 19 was specific to the size or electropositivity of the potassium in $\mathrm{KN}\left\{\mathrm{SiMe}_{3}\right\}_{2}$, an analogous reaction was attempted using $\mathrm{LiN}\left\{\mathrm{SiMe}_{3}\right\}_{2}$. The radius of $\mathrm{Li}^{+}$is smaller, more charge dense, and less electropositive ( $\mathrm{Li}+$ ionic radius is $0.9 \AA$ as opposed to $1.52 \AA$ for $\mathrm{K}+$ ionic radius) 68 . As solubility issues complicated the reaction using the $\left[\mathrm{PPh}_{2}(\mathrm{hppH})\right]^{+}$cation, the originally explored method using neutral $\mathrm{PPh}_{2}(\mathrm{hpp})$ was utilised for this synthesis (Scheme 27).
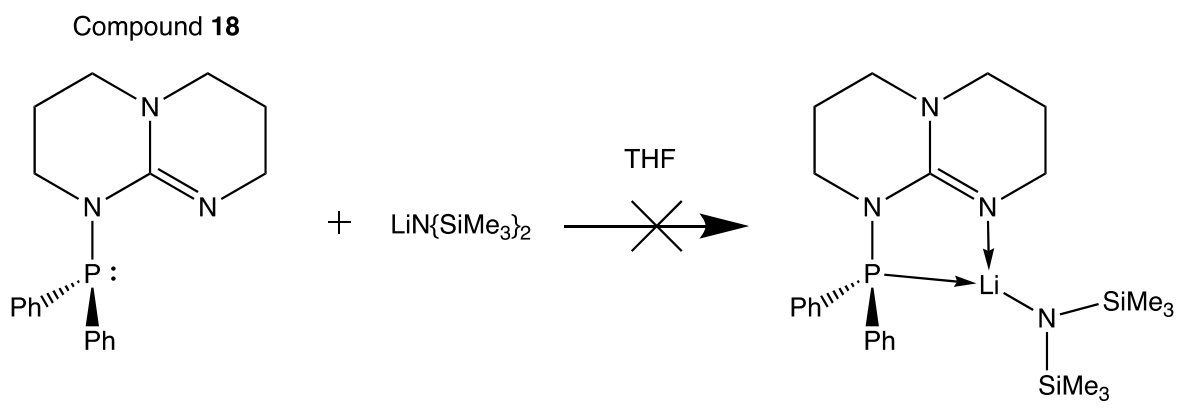

Scheme 27: Attempted synthesis of $\operatorname{LiN}\left\{\mathrm{SiMe}_{3}\right\}_{2} \bullet \mathrm{PPh}_{2}(\mathrm{hpp})$ 
Both $\mathrm{PPh}_{2}(\mathrm{hpp})$ and $\mathrm{LiN}\left\{\mathrm{SiMe}_{3}\right\}_{2}$ were dissolved in THF. The LiN $\left\{\mathrm{SiMe}_{3}\right\}_{2}$ solution was added to the $\mathrm{PPh}_{2}(\mathrm{hpp})$ solution and stirred overnight. Crystallisation occurred very slowly and crystals suitable for X-ray diffraction were discovered after 3 months. A single crystal was extracted from the oily residue and X-ray diffraction studies performed. NMR spectra were, however, contaminated by residual oily product. Spectra therefore show the presence of additional species so are not representative of the pure crystals.

${ }^{1} \mathrm{H}$ and ${ }^{13} \mathrm{C} \mathrm{NMR}$ data was collected and the spectra were cleaner than those of the analogous potassium reaction. There were, however, still multiple peaks between $3.57 \mathrm{ppm}$ and $1.41 \mathrm{ppm}$ where the hpp protons are expected to resonate so assignment of this region of the spectrum was not possible.

In the aromatic region of the ${ }^{1} \mathrm{H}$ NMR spectrum there was a triplet resonance at $7.63 \mathrm{ppm}$ (the meta protons of the phenyl groups), a multiplet at $7.16 \mathrm{ppm}$ (the ortho protons of the phenyl groups) which overlapped with the $\mathrm{C}_{6} \mathrm{D}_{6}$ solvent peak, and another triplet at $7.06 \mathrm{ppm}$ (the para protons of the phenyl groups) This indicates that all of the phenyl rings in the sample are in the same environment. These aromatic resonances were shifted from those in the uncoordinated ligand, which means that none of the starting material remained.

A large $\mathrm{N}\left\{\mathrm{SiMe}_{3}\right\}_{2}{ }^{-}$proton resonance appeared at $0.23 \mathrm{ppm}$. This is downfield from that of free $\mathrm{LiN}\left\{\mathrm{SiMe}_{3}\right\}_{2}$ in $\mathrm{C}_{6} \mathrm{D}_{6}$ which occurs at $0.15 \mathrm{ppm}$. This indicates that the silyl amide group had either coordinated to something other than lithium or that $\operatorname{LiN}\left\{\mathrm{SiMe}_{3}\right\}_{2}$ has been coordinated by another ligand.

The crystal structure obtained (Figure 33), best described as $\mathrm{Li}_{3}\left(\mathrm{~N}\left\{\mathrm{PPh}_{2}\right\}_{2}\right)(\mathrm{hpp})_{2}(\mathrm{THF})_{3}$ (compound 22), showed that $\mathrm{PPh}_{2}(\mathrm{hpp})$ had cleaved at the N-P bond. This is also where the ligand cleaved in the in the 
synthesis of compound 19, evidence that $\mathrm{PPh}_{2}(\mathrm{hpp})$ is susceptible to $\mathrm{P}-\mathrm{N}$ bond cleavage when being used as a ligand on group one metal salts.

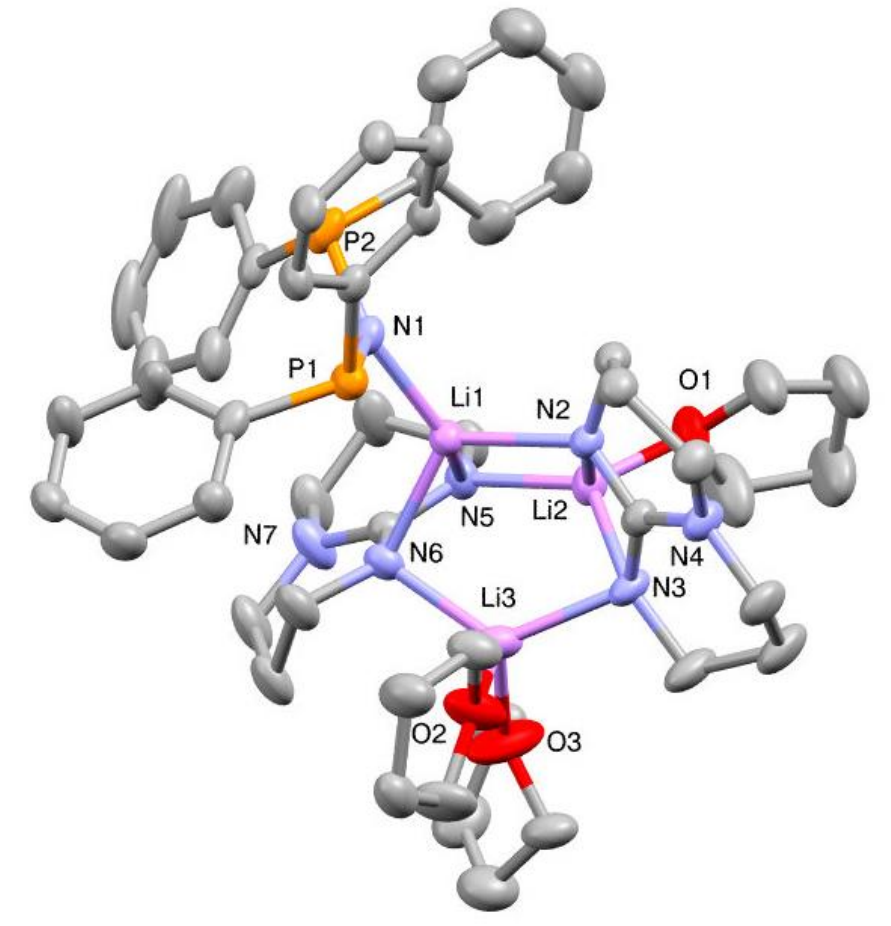

Figure 33: Thermal ellipsoid (50\%) for compound 22. Selected bond lengths and angles have been reported in Tables 5 and 6 respectively. All hydrogen atoms have been omitted for clarity.

\begin{tabular}{|c|c|}
\hline Atoms of Bond & Bond Length (̊) \\
\hline $\mathrm{N}(1) \mathrm{P}(1)$ & $1.6604(16)$ \\
\hline $\mathrm{N}(1) \mathrm{P}(2)$ & $1.6640(16)$ \\
\hline $\operatorname{Li}(1) \mathrm{N}(1)$ & $2.005(3)$ \\
\hline $\operatorname{Li}(1) \mathrm{N}(2)$ & $2.078(3)$ \\
\hline $\operatorname{Li}(1) \mathrm{N}(5)$ & $2.280(3)$ \\
\hline $\operatorname{Li}(1) \mathrm{N}(6)$ & $2.070(3)$ \\
\hline $\operatorname{Li}(2) \mathrm{N}(2)$ & $2.043(3)$ \\
\hline $\operatorname{Li}(2) \mathrm{N}(3)$ & $2.037(4)$ \\
\hline $\operatorname{Li}(3) \mathrm{N}(3)$ & $2.035(4)$ \\
\hline $\operatorname{Li}(3) \mathrm{N}(6)$ & $2.013(4)$ \\
\hline
\end{tabular}

Table 7: Selected bond lengths of 22 


\begin{tabular}{|c|c|}
\hline Atoms & Angle ( $)$ \\
\hline $\mathrm{P}(1) \mathrm{N}(1) \mathrm{P}(2)$ & $122.27(9)$ \\
\hline $\mathrm{N}(2) \mathrm{Li}(2) \mathrm{N}(3)$ & $67.68(12)$ \\
\hline $\mathrm{N}(5) \mathrm{Li}(1) \mathrm{N}(6)$ & $62.60(10)$ \\
\hline $\mathrm{P}(1) \mathrm{N}(1) \mathrm{Li}(1)$ & $99.50(12)$ \\
\hline $\mathrm{P}(2) \mathrm{N}(1) \mathrm{Li}(1)$ & $138.18(13)$ \\
\hline
\end{tabular}

Table 8: Selected bond angles of 22

To explain the structure in Figure 33, we consider it to consist of the formula $\mathrm{Li}_{3}\left(\mathrm{~N}\left\{\mathrm{PPh}_{2}\right\}_{2}\right)(\mathrm{hpp})_{2}(\mathrm{THF})_{3}$ divided into ' $\mathrm{Li}\left(\mathrm{N}\left\{\mathrm{PPh}_{2}\right\}_{2}\right)$ ' and a ' $\mathrm{Li}_{2}(\mathrm{hpp})(\mathrm{THF})_{3}$ ' group. As the $\mathrm{PPh}_{2}(\mathrm{hpp})$ ligand only has one diphenyl phosphine group, the compound formed results from the decomposition of two ligands. Due to the position of the two $\mathrm{PPh}_{2}$ groups in the structure away from the Li-hpp core, no P-Li $\sigma$ interaction can form.

The $\mathrm{N}\left(\mathrm{PPh}_{2}\right)_{2}$ section of the crystal structure has two N-P bonds to the same nitrogen atom (N1). There are two possibilities for its formation. The first is that the nitrogen came from an $\mathrm{N}\left\{\mathrm{SiMe}_{3}\right\}_{2}{ }^{-}$group. This would have required cleavage of both of the $\mathrm{N}\left\{\mathrm{SiMe}_{3}\right\}_{2}{ }^{-} \mathrm{N}-\mathrm{Si}$ bonds. $\mathrm{As}_{\mathrm{S}} \mathrm{SiMe}_{3}$ is a poor leaving group this would seem like an unlikely reaction to have achieved at room temperature. However, hppSiMe $\mathrm{S}_{3}$ has been previously reported as a ligand on copper. ${ }^{79}$ The $\mathrm{SiMe}_{3}$ groups from the $\mathrm{N}\left\{\mathrm{SiMe}_{3}\right\}_{2^{-}}$would have been replaced by the $\mathrm{PPh}_{2}$ groups from the hpp groups of two ligands. This explanation would show that the N-P bond of $\mathrm{PPh}_{2}(\mathrm{hpp})$ had once again been cleaved as was shown in the synthesis of compound 19.

There is also a less likely possibility where an $\mathrm{N}\left(\mathrm{PPh}_{2}\right)$ group from one $\mathrm{PPh}_{2}$ (hpp) ligand was removed from the rest of the hpp group. This would have required the unfavourable removal of a nitrogen atom from a 
resonance stabilised bicyclic hpp group, which involves breaking two C-N bonds in a 6-membered ring. The nitrogen of this cleaved $\mathrm{NPPh}_{2}$ then would have coordinated to another $\mathrm{PPh}_{2}$ group from another ligand, therefore cleaving this other $\mathrm{PPh}_{2}(\mathrm{hpp})$ ligand at its $\mathrm{N}-\mathrm{P}$ bond. Therefore, this second potential explanation would also show that the N-P bond of $\mathrm{PPh}_{2}(\mathrm{hpp})$ had been cleaved as seen in the synthesis of compound 19.

Whether the $\mathrm{N}\left(\mathrm{PPh}_{2}\right)_{2}$ nitrogen originated from an hpp group or an $\mathrm{N}\left\{\mathrm{SiMe}_{3}\right\}_{2}$ - group, $\mathrm{N}\left(\mathrm{PPh}_{2}\right)_{2}$ would have then coordinated to the Li-hpp core of the structure. This three coordinate $\mathrm{N}\left(\mathrm{PPh}_{2}\right)_{2}$ nitrogen must have a lone pair, as nitrogen has five valence electrons. However, the geometry around the nitrogen centre is not trigonal pyramidal as expected. This is shown by the bond angles in the crystallographic data. The geometry of N1 is actually close to planar as the angles between the bonds to $\mathrm{N} 1$ add to nearly $360^{\circ}$ (see Table 8). This means the lone pair must sit above or below this plane, an unlikely geometric conformation which would be forced by the steric bulk of the phenyl groups. Alternatively, the lone pair could be delocalised onto the N-P bonds.

A $\left[\mathrm{N}\left(\mathrm{PPh}_{2}\right)_{2}\right] \mathrm{Li}(\mathrm{THF})_{3}$ compound has been previously synthesised by Schleyer et al. which contains the same $\mathrm{N}\left(\mathrm{PPh}_{2}\right)_{2}$ group as found in $\mathrm{Li}_{3}\left(\mathrm{~N}\left\{\mathrm{PPh}_{2}\right\}_{2}\right)(\mathrm{hpp})_{2}(\mathrm{THF})_{3 .}{ }^{80}$ The N-Li bond length of $\left[\mathrm{N}\left(\mathrm{PPh}_{2}\right)_{2}\right] \mathrm{Li}(\mathrm{THF})_{3}$ was 2.030(1) $\AA$. This is only just longer than the 2.005(3) $\AA$ N1-Li1 bond length of $\mathrm{Li}_{3}\left(\mathrm{~N}\left\{\mathrm{PPh}_{2}\right\}_{2}\right)(\mathrm{hpp})_{2}(\mathrm{THF})_{3}$.

In summary, the chemistry involved in the $\mathrm{N}\left(\mathrm{PPh}_{2}\right)_{2}$ section of the structure could not have been predicted as it is far from the hypothesised ligand behaviour.

The use of THF as a solvent in this synthesis has resulted in the coordination of three THF molecules as ligands to the lithium atoms in the compound formed. Two THF ligands are coordinating to Li3 and the third 
THF ligand is coordinating to Li2. The coordination of the THF molecules as ligands likely stabilised the cage structure and helped crystallisation.

When dissolved in the solvent THF, $\left.\mathrm{LiN}_{2} \mathrm{SiMe}_{3}\right\}_{2}$ forms predominantly a dimer with a THF ligand on each lithium atom. ${ }^{81}$ Therefore, coordination of the THF to lithium could have occurred before the reaction with the $\mathrm{PPh}_{2}(\mathrm{hpp})$ ligand, thus, the structure could have been formed from a combination of two $\mathrm{PPh}_{2}(\mathrm{hpp})$ ligands and one and a half $\mathrm{LiN}\left\{\mathrm{SiMe}_{3}\right\}_{2} \bullet \mathrm{THF}$ dimers.

A proposed scheme for the formation of compound 22 is shown in Scheme 28 whereby $\mathrm{PPh}_{2}(\mathrm{hpp})$ has reacted with $\mathrm{LiN}\left\{\mathrm{SiMe}_{3}\right\}_{2}$ to form compound 22, hppSiMe ${ }_{3}$ and $\mathrm{PPh}_{2}-\mathrm{N}\left\{\mathrm{SiMe}_{3}\right\}_{2}$.

$\left.4 \mathrm{PPh}_{2}(\mathrm{hpp})+3 \mathrm{LiN}\left\{\mathrm{SiMe}_{3}\right\}_{2} \stackrel{\mathrm{THF}}{\longrightarrow} \mathrm{Li}_{3}\left(\mathrm{~N}\left(\mathrm{PPh}_{2}\right)_{2}\right)(\mathrm{hpp})_{2}(\mathrm{THF})_{3}+2 \mathrm{hppSiMe}_{3}+2 \mathrm{PPh}_{2}-\mathrm{N}_{2} \mathrm{SiMe}_{3}\right\}_{2}$

Scheme 28: Proposed balanced equation for the formation of compound 22

To depict the lithium-hpp core of the structure more clearly, the THF ligands coordinated to the lithium atoms and the $\left(\mathrm{PPh}_{2}\right)_{2}$ structure which connects to the core of the compound through N1 have been omitted in Figure 34. The three lithium atoms in the structure are connected through hpp groups. The lithium-hpp core of the crystal structure is almost tubshaped in configuration, comprised of three four-membered rings and with $\mathrm{Li} 3$ bridging $\mathrm{N} 3$ to N6. The angles from the basal plane (Li2-N5-Li1-N2) to the neighbouring four-membered rings are both close to $120^{\circ}$ : the angle from the basal plane to the left hand plane of $\mathrm{N} 2-\mathrm{Li} 2-\mathrm{N} 3-\mathrm{C} 25$ is $118.2^{\circ}$ and the angle from the basal plane to the right hand plane of N5-C32-N6-Li1 is $119.87^{\circ}$. 


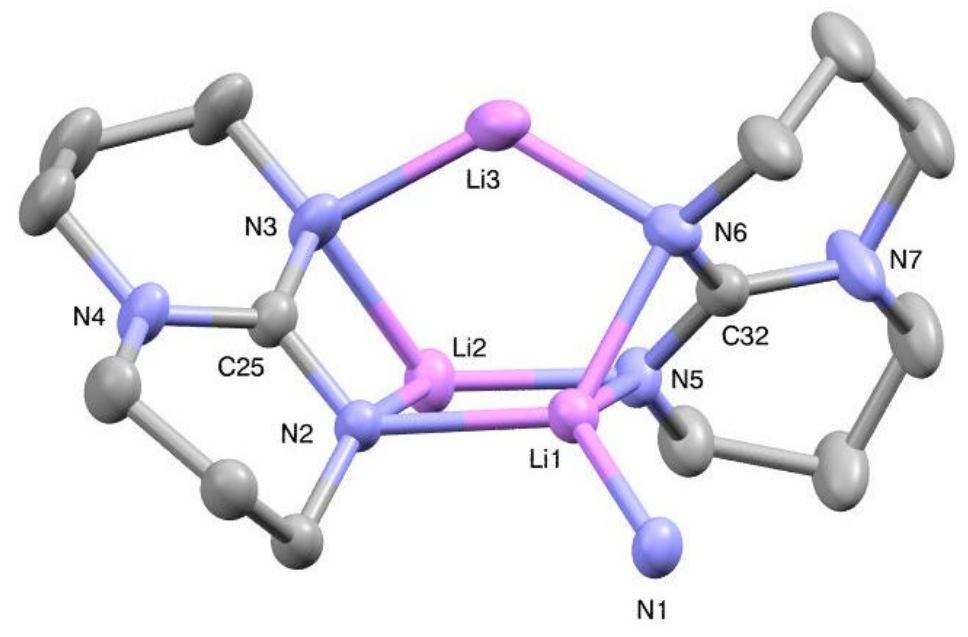

Figure 34: lithium-hpp core simplification of Figure 33. The image shows the tub shape formation of compound 22 from the side.

$\mathrm{N} 2, \mathrm{~N} 3, \mathrm{~N} 5$, and $\mathrm{N} 6$ are coordinating to two lithium atoms each. Li2 is connected to both $\mathrm{N} 3$ and $\mathrm{N} 2$ of the same hpp- ligand and Li1 is doing the same but for the other hpp- ligand. As seen in Table 2, there is only a slight difference between the N2 - Li2 - N3 and N5 - Li1 - N6 angles which are both close to $65^{\circ}$.

Due to the surprising nature of the chemistry which occurred in the attempted synthesis of compound 22, if time had permitted, DFT (Density functional theory) calculations would have been performed to gain further insight into the bonding that is present in this structure.

\section{Attempted synthesis of $\mathrm{AlMe}_{3} \bullet \mathrm{PPh}_{2}(\mathrm{hpp})$}

As the ligand was unstable during attempts to coordinate to group one $\mathrm{N}\left\{\mathrm{SiMe}_{3}\right\}_{2}{ }^{-}$salts, the project moved towards other metal compounds without an $\mathrm{N}\left\{\mathrm{SiMe}_{3}\right\}_{2} 2^{-}$ligand. The readily available group 13 metal compound trimethylaluminium was trialled as alternative metal centre for the coordination of $\mathrm{PPh}_{2}(\mathrm{hpp})$. Aluminium is similar to potassium and lithium in that it is small with a high charge density. 
A solution of $\mathrm{AlMe}_{3}$ in toluene was added dropwise to $\mathrm{PPh}_{2}(\mathrm{hpp})$ (dissolved in THF). The reaction produced large colourless block-shaped crystals. The expected result of this synthesis was to cleave the $\mathrm{AlMe}_{3}$ dimer and subsequently coordinate $\mathrm{PPh}_{2}(\mathrm{hpp})$ to the $\mathrm{AlMe}_{3}$ monomer.<smiles>c1ccc([Pb](c2ccccc2)N2CCCN3CCCN=C32)cc1</smiles>

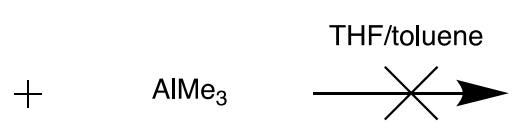

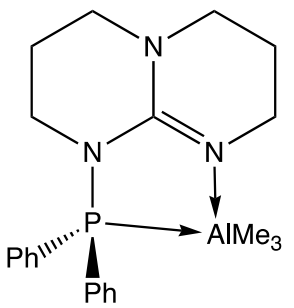

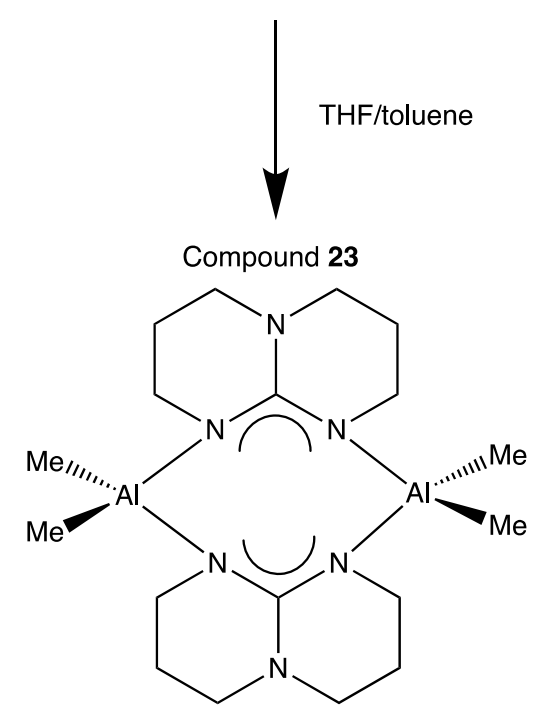

Scheme 29: Attempted synthesis of $\mathrm{AlMe}_{3} \bullet \mathrm{PPh}_{2} \mathrm{hpp}$ and subsequent synthesis of $\left\{(\mu \text {-hpp })-\mathrm{AlMe}_{2}\right\}_{2}$

In the ${ }^{1} \mathrm{H}$ NMR spectrum of the uncomplexed $\mathrm{PPh}_{2}(\mathrm{hpp})$ ligand, there are six proton resonances (although some are overlapping) for the hpp protons in accordance with the six proton environments present. The new compound formed, however, had only three proton resonances for the hpp protons. This could indicate the existence of a symmetrical and negatively charged hppligand in the newly synthesised compound. The multiplicity pattern of the peaks also supports the formation of hpp-. These resonances are triplets at $3.11 \mathrm{ppm}$ (the protons on carbon 1 in Figure 35) and $2.39 \mathrm{ppm}$ (the protons of carbon 3 in Figure 35) and a quintet at $1.49 \mathrm{ppm}$ (the protons of carbon 2 in Figure 35). Having this NMR data supported the presence of a 
symmetrical hpp- ligand in the compound as an indication that the $\mathrm{PPh}_{2} \mathrm{hpp}$ ligand may have cleaved at the N-P bond again.

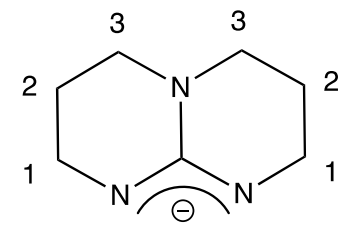

Figure 35: [hpp]- ligand

The ${ }^{1} \mathrm{H}$ NMR data obtained also showed a resonance at $-0.33 \mathrm{ppm}$. This resonance is an indication that metal-methyl bonds are still present in the compound. The resonance integrated to a ratio of six methyl protons for every one hpp group.

The crystal structure obtained showed $\mathrm{PPh}_{2}(\mathrm{hpp})$ had not successfully coordinated to $\mathrm{AlMe}_{3}$. Instead, the previously published compound $\{(\mu$-hpp $)$ AlMe2\}2 (Figure 36) had been synthesised.82 Jordan et al. synthesised compound 23 through the addition of $\mathrm{AlMe}_{3}$ to hppH. As 23 was not novel to this project, full collection of the X-ray data was not performed.

When taking into consideration the change in NMR solvent, the ${ }^{1} \mathrm{H}$ NMR spectra of 23 was mainly in agreement with that of the $\left\{(\mu \text {-hpp })-\mathrm{AlMe}_{2}\right\}_{2}$ synthesised by Jordan et al. However, there are two exceptions to this. Firstly, the occurrence of an unassigned broad singlet resonance at 1.37 ppm. This peak cannot be a solvent impurity from THF as the other THF resonance at $3.57 \mathrm{ppm}$ is not present, nor can it be a solvent impurity from toluene as resonances would appear at $2.11 \mathrm{ppm}, 7.02$ and $7.13 \mathrm{ppm}$ which are not present.

Secondly, the aromatic peaks at $7.36 \mathrm{ppm}$ and $7.06 \mathrm{ppm}$ which had a combined integration of $10 \mathrm{H}$ (in reference to the hpp peaks each with an integration of $8 \mathrm{H})$ are not to be expected in $\left\{(\mu-\mathrm{hpp})-\mathrm{AlMe}_{2}\right\}_{2}$ as it has no 
aromatic rings. These aromatic proton resonances were shifted slightly upfield in comparison to those present in the uncomplexed $\mathrm{PPh}_{2}(\mathrm{hpp})$ ligand, which indicates a change in the environment of the phenyl protons. It would be unsurprising to see residual aromatic resonances in the spectrum if it had been the solution itself that was evaporated and used for NMR. However, the ${ }^{1} \mathrm{H}-\mathrm{NMR}$ was performed on some of the crystals from the sample, not from the solution. The crystals dissolved in $\mathrm{C}_{6} \mathrm{D}_{6}$ for NMR analysis may have been impure with a side product of $\mathrm{Ph}_{2} \mathrm{P}^{-} \mathrm{PPh}_{2}$ (as $\mathrm{PPh}_{2}$ would be unstable without the phosphorus having a third bond). To test if any phosphorus was present alongside these aromatic resonances, a ${ }^{31} \mathrm{P}$ NMR spectrum of the compound was collected which showed one singlet resonance at $-27 \mathrm{ppm}$. This is in support of $\mathrm{Ph}_{2} \mathrm{P}-\mathrm{PPh}_{2}$, whereby one phosphorus resonance would be expected that would be a singlet as the phosphorus atoms would not couple to anything as they are not bonded to hydrogen or metals and both phosphorus atoms are in the same environment. The aforementioned integration of the aromatic peaks adding to $10 \mathrm{H}$ means there is half a $\mathrm{Ph}_{2} \mathrm{P}-\mathrm{PPh}_{2}$ for every $\left\{(\mu \text {-hpp })-\mathrm{AlMe}_{2}\right\}_{2}$ in the crystalline solid used to collect the NMR data, however, the crystal structure itself had no sign of diphenyl phosphine groups.

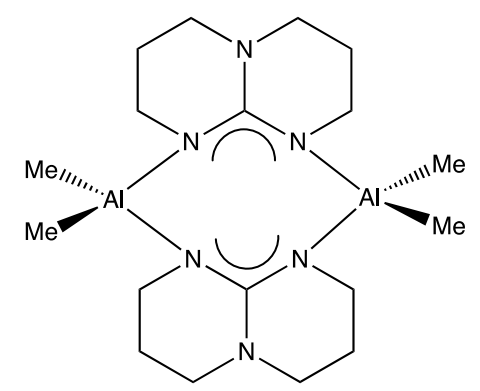

Figure 36: $\left\{(\mu-\mathrm{hpp})-\mathrm{AlMe}_{2}\right\}_{2}$

The results of this experiment also showed how unstable the N-P bond between the hpp nitrogen and the diphenylphosphine phosphorus is as the 
attempted coordination resulted in the cleavage of this bond and the bridging coordination of the [hpp]- ligand to dimethyl aluminium.

\section{Summary and Conclusions}

The $\mathrm{PPh}_{2}$ (hpp) ligand was utilised in an attempt to coordinate an hpp based ligand to a group one metal salt to complement the concurrent work described in Chapter Two. This N-phosphino guanidine ligand system aimed to achieve nitrogen (and potentially phosphorus) $\sigma$ donation without the added complication of trying to accomplish an aromatic interaction. As the research in Chapter Two was being conducted using the soluble group one metal salts $\mathrm{KN}\left\{\mathrm{SiMe}_{3}\right\}_{2}$ and $\mathrm{LiN}\left\{\mathrm{SiMe}_{3}\right\}_{2}$ simultaneously, attempts were made to coordinate $\mathrm{PPh}_{2}$ (hpp) to these metals so that coordination modes could be compared. These synthetic attempts gave unexpected and fascinating results. The crystals structures obtained from these compounds showed the ligand had broken apart during coordination attempts, having cleaved at the N-P bond where the $\mathrm{PPh}_{2}$ and hpp had been joined. The cleavage of the ligand during the effort to coordinate $\mathrm{PPh}_{2}(\mathrm{hpp})$ to $\mathrm{AlMe}_{3}$ showed that the steric bulk of the $\mathrm{N}\left\{\mathrm{SiMe}_{3}\right\}_{2}{ }^{-}$group was not the cause of the ligand falling apart because a new method for synthesising $\left\{(\mu-\mathrm{hpp})-\mathrm{AlMe}_{2}\right\}_{2}$ was established unexpectedly due to another incidence of ligand cleavage, and $\mathrm{AlMe}_{3}$ is far less bulky than $\mathrm{KN}\left\{\mathrm{SiMe}_{3}\right\}_{2}$ and $\left.\mathrm{LiN}_{2} \mathrm{SiMe}_{3}\right\}_{2}$. The steric bulk of the phenyl groups on the ligand may have hindered the coordination of $\mathrm{PPh}_{2}$ hpp to the various metal centres in this study. Therefore, future work would encompass experimental work focusing on the synthesis and subsequent coordination of phosphine-hpp ligands comprised of phosphine groups with $\mathrm{R}$ groups less bulky than phenyl groups, such as a tertiary butyl groups.

As Dyer et al. had successfully performed the coordination of $\mathrm{PPh}_{2}(\mathrm{hpp})$ to $\mathrm{NiBr}_{2}, 77$ if time had permitted, an extension of the transition metal research trying to coordinate $\mathrm{PPh}_{2}(\mathrm{hpp})$ to transitional metals would have been 
undertaken because evidence of ligand fragmentation had not been published by Dyer et al. This research would have worked towards the final goal of forming ruthenium complexes. However, after limited success in this area of the research project, alternative areas of the project were prioritised. 


\section{Chapter Five}

\section{Attempted Coordination of Arene-hpp Ligands to Transition Metals}

\section{Introduction}

Preliminary work on transition metal chemistry for this thesis focused on the attempted coordination of the $\mathrm{Ph}\left(\mathrm{CH}_{2} \mathrm{hpp}\right)$ ligand to transition metal salts, which are cheaper alternatives to ruthenium. A crystal structure of $\mathrm{Ph}\left(\mathrm{CH}_{2} \mathrm{hpp}\right)$ coordinating to $\mathrm{NaN}\left\{\mathrm{SiMe}_{3}\right\}_{2}$ was obtained in Chapter 2 which proved the ligand was suitable for metal coordination. However, the attempts to coordinate $\mathrm{Ph}\left(\mathrm{CH}_{2} \mathrm{hpp}\right)$ to transition metal salts were hindered by solubility issues. $\mathrm{MnCl}_{2}, \mathrm{CuCl}$, and $\mathrm{CoCl}_{2}$ are not soluble in solvents suitable for air and moisture sensitive reactions so a method of solubilising the metal salts needed to be introduced.

In Chapter Four, the protonation of $\mathrm{PPh}_{2}(\mathrm{hpp})$ was carried out to synthesise $\left[\mathrm{PPh}_{2}(\mathrm{hppH})\right]^{+}$. The protonated ligand was then used in an attempt to coordinate $\mathrm{PPh}_{2} \mathrm{hpp}$ to $\mathrm{KN}\left\{\mathrm{SiMe}_{3}\right\}_{2}$. Solubility issues prevented a successful outcome for this coordination attempt, but this work was chosen as a trial for the attempted synthesis of $\mathrm{Mn} \bullet \mathrm{Ph}\left(\mathrm{CH}_{2} \mathrm{hpp}\right)$.

\section{Synthesis of $\left[\mathrm{Ph}\left(\mathrm{CH}_{2} \mathrm{hppH}\right]\left[\mathrm{BPh}_{4}\right]\right.$}

Protonation of $\mathrm{Ph}\left(\mathrm{CH}_{2} \mathrm{hpp}\right)$ was achieved by a reaction with $\left[\mathrm{HNEt}_{3}\right]\left[\mathrm{BPh}_{4}\right]$ in the same way as $\mathrm{PPh}_{2}(\mathrm{hpp})$ was protonated as described in Chapter Four (Scheme 30). 


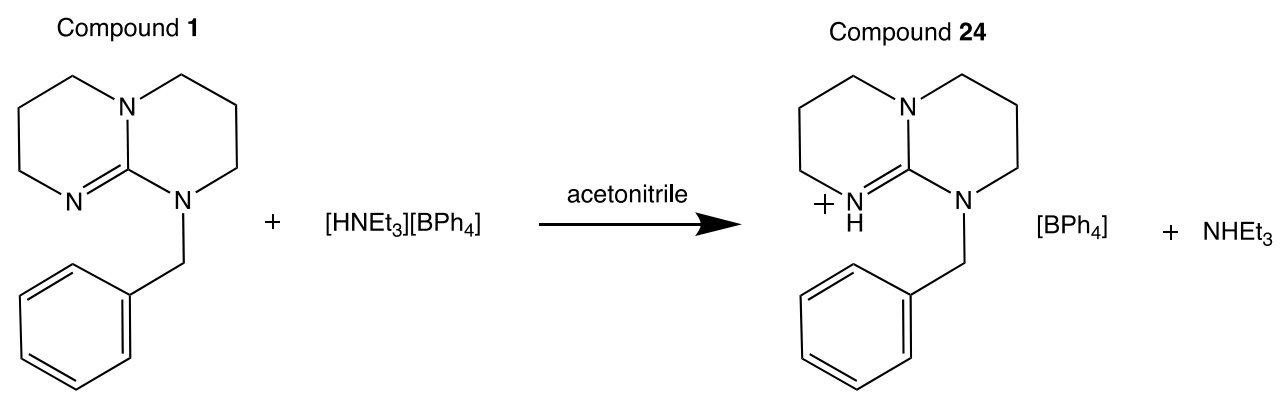

Scheme 30: Synthesis of $\left[\mathrm{Ph}\left(\mathrm{CH}_{2} \mathrm{hppH}\right]\left[\mathrm{BPh}_{4}\right]\right.$

\section{Attempted Synthesis of $\left[\mathrm{Ph}\left(\mathrm{CH}_{2} \mathrm{hpp}\right) \bullet \mathrm{MnN}\left\{\mathrm{SiMe}_{3}\right\}_{2}\right]\left[\mathrm{BPh}{ }_{4}\right]$}

Once $\left[\mathrm{PPh}_{2} \mathrm{hppH}\right]\left[\mathrm{BPh}_{4}\right]$ had been synthesised, an attempt to synthesise the manganese starting material, $\mathrm{Mn}\left(\mathrm{N}\left\{\mathrm{SiMe}_{3}\right\}_{2}\right)_{2}$, was conducted (Scheme 31 ).

$$
2 \mathrm{LiN}\left\{\mathrm{SiMe}_{3}\right\}_{2}+\mathrm{MnCl}_{2} \stackrel{\text { toluene }}{\longrightarrow} \mathrm{Mn}\left(\mathrm{N}\left\{\mathrm{SiMe}_{3}\right\}_{2}\right)_{2}+2 \mathrm{LiCl}
$$

Scheme 31: Attempted synthesis of $\mathrm{Mn}\left(\mathrm{N}\left\{\mathrm{SiMe}_{3}\right\}_{2}\right)_{2}$

The black precipitate was removed by filtration and the resultant yelloworange solution was concentrated in vacuo. Crystallisation occurred at $30^{\circ} \mathrm{C}$. However, the crystals were discovered to be $\left.\mathrm{LiN} \mathrm{SiMe}_{3}\right\}_{2}$. The

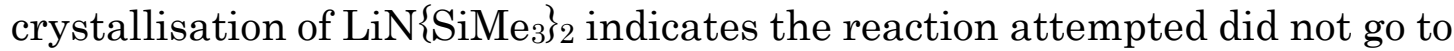
completion. This is likely to have been caused by the low solubility of $\mathrm{MnCl}_{2}$ in toluene. The black precipitate removed via filtration was likely a manganese compound, leaving $\mathrm{LiN}\left\{\mathrm{SiMe}_{3}\right\}_{2}$, which readily crystallises.

After unsuccessful attempts at the synthesis of $\mathrm{Mn}\left(\mathrm{N}\left\{\mathrm{SiMe}_{3}\right\}_{2}\right)_{2}$, an in situ attempt at the synthesis of $\mathrm{Mn} \bullet \mathrm{Ph}\left(\mathrm{CH}_{2} \mathrm{hpp}\right)$ was conducted. This synthesis would not involve the isolation of the $\mathrm{Mn}\left(\mathrm{N}\left\{\mathrm{SiMe}_{3}\right\}_{2}\right)_{2}$ product. It was also performed in the more polar solvent THF (as opposed to toluene). THF had 
the potential to coordinate to any compounds synthesised, but if this were to occur it would not necessarily be a problem as it may aid crystallisation.

\section{Attempted In-situ Synthesis of $\left[\mathrm{Ph}\left(\mathrm{CH}_{2} \mathrm{hpp}\right) \bullet \mathrm{MnN}\left\{\mathrm{SiMe}_{3}\right\}_{2}\right]\left[\mathrm{BPh}_{4}\right]$}

The synthesis of $\mathrm{Mn} \bullet \mathrm{Ph}\left(\mathrm{CH}_{2} \mathrm{hpp}\right)$ was attempted via the lithiation of $\mathrm{HN}\left\{\mathrm{SiMe}_{3}\right\}_{2}$ with $\mathrm{n}-\mathrm{BuLi}$ followed by the addition of $\mathrm{MnCl}_{2}$ and $\left[\mathrm{Ph}\left(\mathrm{CH}_{2} \mathrm{hppH}\right)\right]\left[\mathrm{BPh}_{4}\right]$ (Scheme 32). However, a black precipitate was again formed. The solvent was removed in vacuo before the solid was redissolved in hexane. The resultant black solution was filtered through celite to afford a clear pale yellow solution. Crystallisation occurred from the solution at $30^{\circ} \mathrm{C}$ within 24 hours. NMR data was not collected for the sample as it was likely to be a paramagnetic compound.
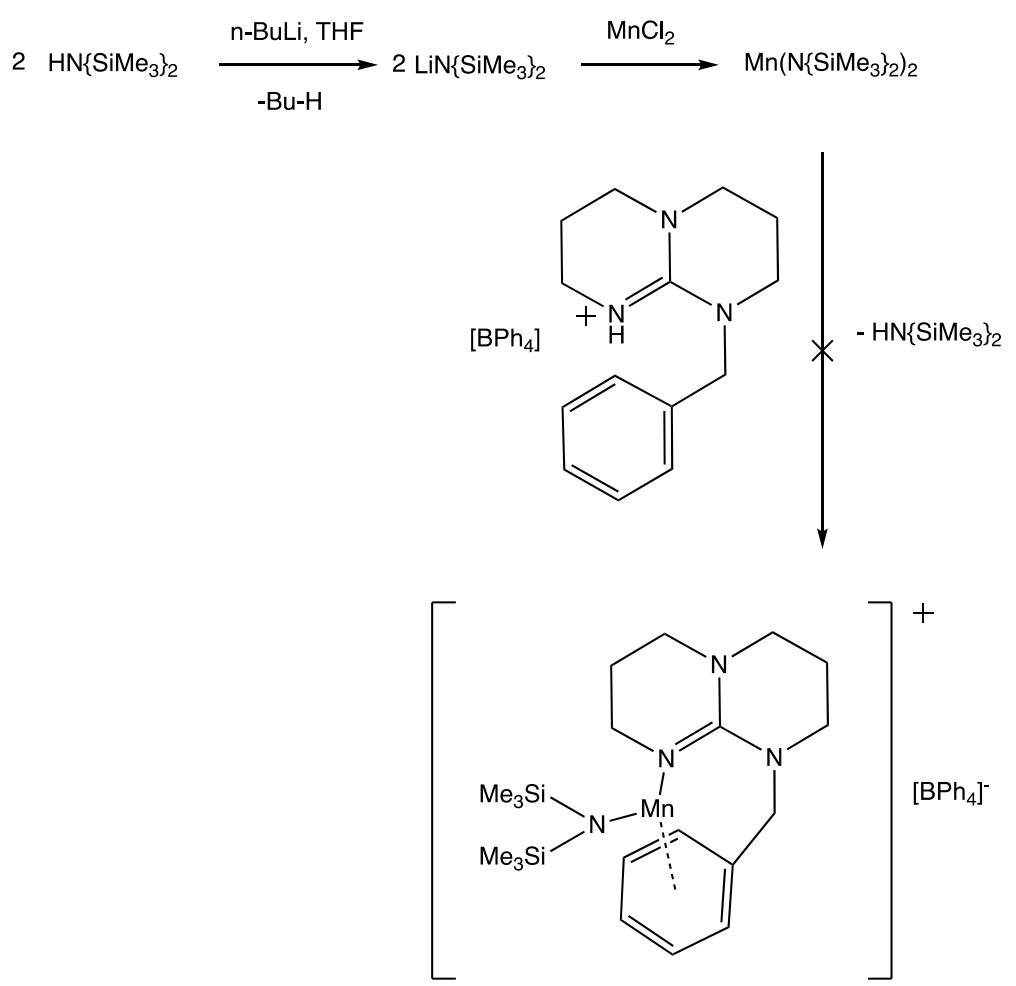

Scheme 32: Attempted synthesis of $\left[\mathrm{Ph}\left(\mathrm{CH}_{2} \mathrm{hpp}\right) \bullet \mathrm{MnN}\left\{\mathrm{SiMe}_{3}\right\}_{2}\right]\left[\mathrm{BPh}_{4}\right]$ 
The crystals obtained were suitable for X-ray diffraction. The structure of compound 25 (Figure 37 ) shows a bridging chloride linking $\mathrm{Mn}\left(\mathrm{N}\left\{\mathrm{SiMe}_{3}\right\}_{2}{ }^{-}\right.$ )$_{2}$ with $\mathrm{Li}(\mathrm{THF})_{3}$. Therefore, the manganese in the compound synthesised is three coordinate with two $\mathrm{N}\left\{\mathrm{SiMe}_{3}\right\}_{2}-$ ligands and the $\mathrm{Cl}-\mathrm{Li}(\mathrm{THF})_{3}$ component of the structure acting as the third ligand. The lithium in this structure is therefore four coordinate. Given that the two $\mathrm{N}\left\{\mathrm{SiMe}_{3}\right\}_{2}{ }^{-}$groups and the chloride have a - 1 charge, the THF ligands are neutral, and lithium only has one possible oxidation state of +1 , the manganese must be in a +2 oxidation state. The novel compound produced is the manganese analogue of an iron compound synthesised by Siemeling et al. ${ }^{83}$ The method performed by Siemeling et al. was a failed attempt to synthesise $\mathrm{CpFeN}\left(\mathrm{SiMe}_{3}\right)_{2}$. Their accidental synthesis of $\left[\left(\mathrm{Me}_{3} \mathrm{Si}_{2}\right)_{2} \mathrm{~N}_{2} \mathrm{Fe}(\mu-\mathrm{Cl}) \mathrm{Li}(\mathrm{THF})_{3}\right.$ occurred by adding $\mathrm{KN}\left\{\mathrm{SiMe}_{3}\right\}_{2}{ }^{-}$to $\mathrm{FeCl}_{2}$ in THF, followed by the addition of $\mathrm{CpLi} .{ }^{83}$

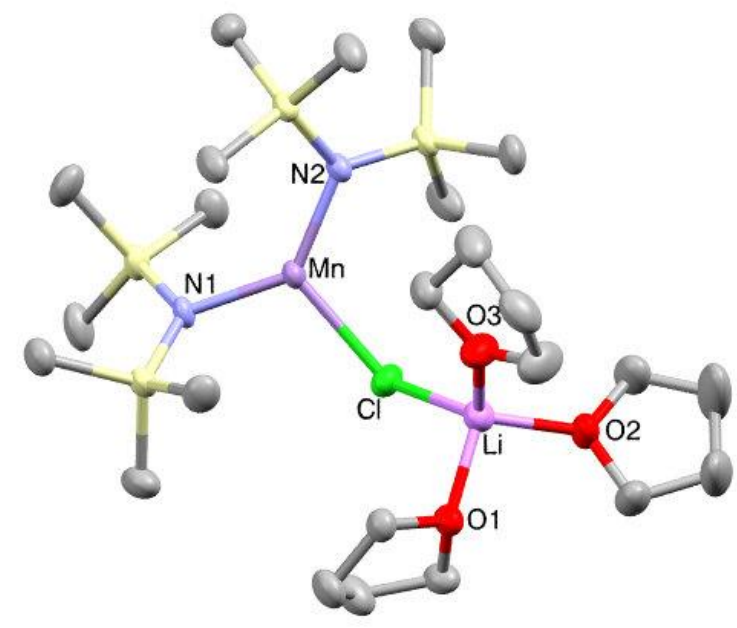

Figure 37: Thermal ellipsoid (50\%) for compound 25. All hydrogen atoms have been omitted for clarity. 


\begin{tabular}{|c|c|}
\hline Atoms of Bond & Bond Length $(\AA)$ \\
\hline Mn Cl & $2.3992(11)$ \\
\hline Mn N(1) & $2.019(3)$ \\
\hline Mn N(2) & $2.011(3)$ \\
\hline Li Cl & $2.319(7)$ \\
\hline Li O(1) & $1.940(8)$ \\
\hline Li O(2) & $1.907(8)$ \\
\hline Li O(3) & $1.910(8)$ \\
\hline
\end{tabular}

Table 9: Selected Bond Lengths for compound 25

\begin{tabular}{|c|c|}
\hline Atoms & Angle $\left.{ }^{\circ}\right)$ \\
\hline $\mathrm{Mn} \mathrm{N}(1) \mathrm{Si}(1)$ & $119.53(16)$ \\
\hline $\mathrm{Si}(1) \mathrm{N}(1) \mathrm{Si}(2)$ & $125.65(18)$ \\
\hline $\mathrm{Si}(2) \mathrm{N}(1) \mathrm{Mn}$ & $114.51(16)$ \\
\hline $\mathrm{Mn} \mathrm{N}(2) \mathrm{Si}(3)$ & $118.25(16)$ \\
\hline $\mathrm{Si}(3) \mathrm{N}(2) \mathrm{Si}(4)$ & $123.31(18)$ \\
\hline $\mathrm{Si}(4) \mathrm{N}(2) \mathrm{Mn}$ & $118.37(16)$ \\
\hline $\mathrm{Mn} \mathrm{Cl} \mathrm{Li}$ & $127.84(18)$ \\
\hline $\mathrm{N}(1) \mathrm{Mn} \mathrm{N}(2)$ & $132.75(13)$ \\
\hline $\mathrm{N}(2) \mathrm{Mn} \mathrm{Cl}$ & $116.03(9)$ \\
\hline $\mathrm{Cl} \mathrm{Mn} \mathrm{N(1)}$ & $111.22(10)$ \\
\hline
\end{tabular}

Table 10: Notable Bond Angles for compound 25

Despite manganese being three coordinate in this compound, its ligands are less evenly spaced around the metal centre giving a highly distorted 
trigonal planar shape around the metal. There is an increased distance between $\mathrm{N} 1$ and N2 $\left(\mathrm{N} 1-\mathrm{Mn}-\mathrm{N} 2\right.$ is $\left.132.75(13)^{\circ}\right)$. This will be due to the steric bulk of the two [N\{SiMe $\left.\}_{2}\right]-$ groups which pushes the [N\{SiMe $\left.\}_{2}\right]-$ nitrogen atoms apart and thus reducing both the $\mathrm{N} 2-\mathrm{Mn}-\mathrm{Cl}$ and $\mathrm{Cl}-\mathrm{Mn}-\mathrm{N} 1$ bond angles.

Manganese and iron are next to each other in the periodic table. Therefore, as there is only a slight difference in nuclear charge between the two metals, it was to be expected that the bond lengths and angles of compound 25 are similar to those in the iron analogue synthesised by Siemeling et al. The $\mathrm{Li}^{-}$ $\mathrm{Cl}$ bond length was 2.319(7) $\AA$, which is just less than that of the analogous iron structure: $2.345(13) \AA .83$ As expected, Li-O bond lengths are nearly identical to those in the iron analogue. The $\mathrm{N}\left\{\mathrm{SiMe}_{3}\right\}_{2}{ }^{-}$nitrogen atoms labelled N1 and N2 have a distorted trigonal planar shape as the angles between nitrogen's bonds to surrounding Mn, Si1 and Si2 are close to all close to $120^{\circ}$ (see table 10 ).

The strength of a $\mathrm{Li}-\mathrm{Cl}$ bond and the Brønsted basicity of the $\mathrm{N}^{\left.-\mathrm{SiMe}_{3}\right\}_{2}-}$ ligands on the manganese should have allowed for compound 25 to be an acceptable substitute to use in place of $\mathrm{Mn}\left(\mathrm{N}\left\{\mathrm{SiMe}_{3}\right\}_{2}\right)_{2}$. Therefore, an attempt was made to use compound $\mathbf{2 5}$ as the starting material for coordinating the protonated $\mathrm{Ph}\left(\mathrm{CH}_{2} \mathrm{hpp}\right)$ ligand to manganese. 


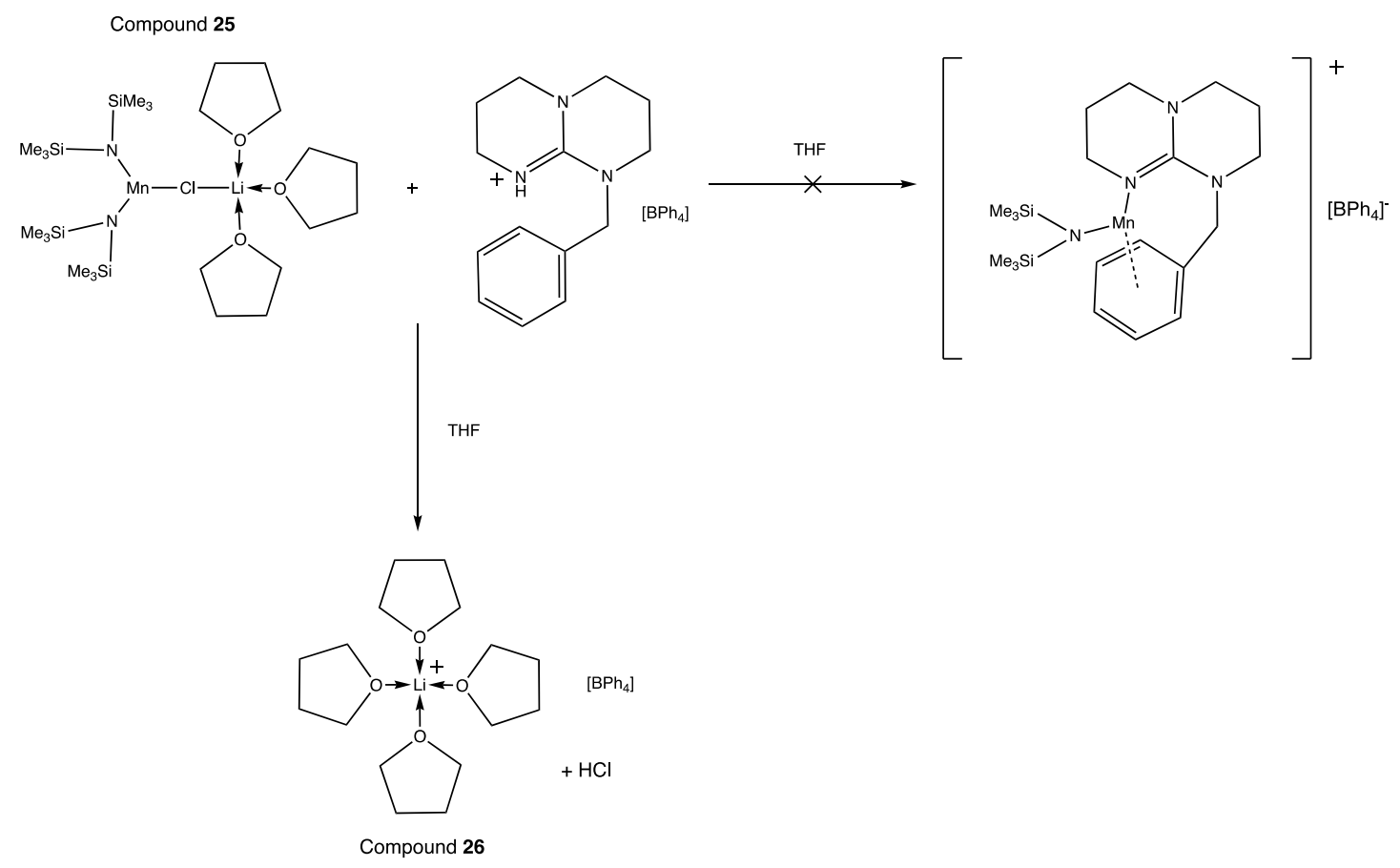

Scheme 33: Re-attempted synthesis of $\mathrm{Mn} \bullet \mathrm{Ph}\left(\mathrm{CH}_{2} \mathrm{hpp}\right)$ and subsequent synthesis of $\left[\mathrm{Li}(\mathrm{THF})_{4}\right][\mathrm{BPh} 4]$

The crystals attained were found to be $\left[\mathrm{Li}(\mathrm{THF})_{4}\right]\left[\mathrm{BPh}_{4}\right]$. As this is not a novel crystal structure, ${ }^{84}$ complete crystallographic data was not collected. The small amount of crystalline material obtained was used for X-ray crystallography, therefore no NMR data could be collected on $\left[\mathrm{Li}(\mathrm{THF})_{4}\right]\left[\mathrm{BPh}_{4}\right]$. This synthesis of compound 26 proves that the $\mathrm{Li}(\mathrm{THF})_{3}$ component of compound 25 was relevant to its reactivity. This is contrary to what was expected as it was hypothesised that due to the strength of the $\mathrm{Li}-\mathrm{Cl}$ bond, $\mathrm{Cl}-\mathrm{Li}(\mathrm{THF})_{3}$ would cleave from the $\mathrm{Mn}\left(\mathrm{N}\left\{\mathrm{SiMe}_{3}\right\}_{2}\right)_{2}$ unit and should not interfere with reactivity. The synthesis of $\left[\mathrm{Li}(\mathrm{THF})_{4}\right]\left[\mathrm{BPh}_{4}\right]$ shows that lithium and chloride did not remain bonded and that a THF ligand took the place of the chloride around the lithium atom.

As THF acts as a neutral ligand and chloride is a negatively charged ligand, THF should not have a stronger interaction with lithium than chloride would. Therefore, the result obtained in Scheme 33 strongly suggests that 
chloride had bonded exclusively to manganese upon the second addition of $\left[\mathrm{PCH}_{2} \mathrm{hppH}\right]\left[\mathrm{BPh}_{4}\right]$ and is no longer bridging manganese to lithium. This would have required cleavage of the $\mathrm{Li}^{-} \mathrm{Cl}$ bond in 25 . which implies the $\mathrm{Mn}^{-}$ $\mathrm{Cl}$ bond was stronger in compound 1 . In an ionic lattice the $\mathrm{Mn}-\mathrm{Cl}$ bond would be stronger because, as previously discussed, manganese is a divalent cation in this compound whereas lithium is a monovalent cation. However, this is not supported by the crystallographic data because the $\mathrm{Mn}-\mathrm{Cl}$ bond length is slightly longer (therefore weaker) than the $\mathrm{Li}-\mathrm{Cl}$ bond length by $0.08 \AA$. This longer bond length could arise from steric interaction between the large chloride anion and the bulky $\mathrm{N}\left\{\mathrm{SiMe}_{3}\right\}_{2}{ }^{-}$groups. Furthermore, THF appearing as a ligand in this compound is an indication that THF may be a stronger ligand than $\mathrm{Ph}\left(\mathrm{CH}_{2} \mathrm{hpp}\right)$ as THF is bonded to lithium instead of the $\mathrm{Ph}\left(\mathrm{CH}_{2} \mathrm{hpp}\right)$ which was available in excess.

\section{Summary and Conclusions}

Due to time constraints, only a limited amount of transition metal chemistry could be attempted. As this project was new to the research group, and these ligands had never been coordinated to metals before, the invaluable proof of concept chemistry needed to be done to understand the behaviour of arene-hpp ligands upon coordination attempts with metals. A novel manganese crystal structure was obtained in an effort to coordinate $\mathrm{Ph}\left(\mathrm{CH}_{2} \mathrm{hpp}\right)$ to $\mathrm{MnCl}_{2}$. 


\section{Chapter Six}

\section{Concluding Remarks}

The project began with coordination attempts using arene-hpp ligands with varying substitution patterns around the aromatic ring. The successful synthesis of $\left(\mathrm{NaN}\left\{\mathrm{SiMe}_{3}\right\}_{2}\right)_{2} \bullet 2\left(\mathrm{Ph}\left(\mathrm{CH}_{2} \mathrm{hpp}\right)\right)$ with its accompanying novel crystal structure was the first arene-hpp ligand to be coordinated to a metal. NMR evidence supported that coordination of $\mathrm{Ph}\left(\mathrm{CH}_{2} \mathrm{hpp}\right)$ had also occurred with $\mathrm{LiN}\left\{\mathrm{SiMe}_{3}\right\}_{2}$ and $\mathrm{KN}\left\{\mathrm{SiMe}_{3}\right\}_{2}$ however no crystal structures were obtained for these compounds to confirm the coordination mode.

The next step in the project was the use of arene-hpp ligands which could behave in a bidentate or tridentate manner. 1,2-( $\left(\mathrm{CH}_{2} \mathrm{hpp}\right)_{2}-\mathrm{C}_{6} \mathrm{H}_{4}$ was successfully coordinated to $\mathrm{KN}\left\{\mathrm{SiMe}_{3}\right\}_{2}$ through both hpp groups yielding another novel crystal structure. Again, NMR evidence indicated the same coordination had occurred with $\operatorname{LiN}\left\{\mathrm{SiMe}_{3}\right\}_{2}$ and $\mathrm{NaN}_{2}\left\{\mathrm{SiMe}_{3}\right\}_{2}$ but the supporting crystal structures could not be obtained. The formation of a polymer upon the attempted synthesis of $\mathrm{KN}\left\{\mathrm{SiMe}_{3}\right\}_{2} \bullet 1,3-\left(\mathrm{CH}_{2} \mathrm{hpp}\right)_{2}-\mathrm{C}_{6} \mathrm{H}_{4}$ provided another crystal structure in which a different coordination mode was adopted, which revealed information about the differences between the two ligands. The analogous coordination attempts of $1,4-\left(\mathrm{CH}_{2} \mathrm{hpp}\right)_{2}-\mathrm{C}_{6} \mathrm{H}_{4}$ and 1,3,5-( $\left.\mathrm{CH}_{2} \mathrm{hpp}\right)_{3}-\mathrm{C}_{6} \mathrm{H}_{3}$ to $\mathrm{KN}\left\{\mathrm{SiMe}_{3}\right\}_{2}$ did not yield any crystal structures however NMR data supported successful coordination.

To test whether the ligands were capable of higher order hapticity aromatic interactions, the proof of concept chemistry was extended to antimony and bismuth which form strong $\pi$ interactions with aromatic rings. This research was a balancing act between solubility and sterics, however, a crystal structure was obtained during an attempt at coordinating 1,2$\left(\mathrm{CH}_{2} \mathrm{hpp}\right)_{2}-\mathrm{C}_{6} \mathrm{H}_{4}$ to $\mathrm{SbCl}_{3}$ which showed that an intramolecular $\mathrm{C}-\mathrm{H}$ 
activation had occurred within the ligand forming a zwitterionic ligand bonded to $\mathrm{SbCl}_{3}$ through one hpp unit only.

Another aspect of this work used the hpp-diphenylphosphine ligand $\mathrm{PPh}_{2}$ (hpp). This ligand was not successfully coordinated to any metals but two unexpected novel crystal structures were attained of potassium and lithium clusters which gave insight into the chemistry of the $\mathrm{PPh}_{2}(\mathrm{hpp})$ ligand, and highlighted the reactive $\mathrm{P}-\mathrm{N}$ bond.

The last aspect of this project as an extension of the proof of concept work, was the attempted coordination of arene-hpp ligands to transition metals. Work in this area was limited due to time constraints. However, one unexpected novel crystal structure of $\left[\left(\mathrm{Me}_{3} \mathrm{Si}\right)_{2} \mathrm{~N}\right]_{2} \mathrm{Mn}(\mu-\mathrm{Cl}) \mathrm{Li}(\mathrm{THF})_{3}$ was obtained in an attempt to coordinate $\mathrm{PPh}_{2}(\mathrm{hpp})$ to $\mathrm{MnCl}_{2}$.

Unfortunately, time did not permit for the extension of this research into coordination to ruthenium. However, arene-hpp ligands have been proven in this thesis to be capable of both $\sigma$ and $\pi$ interactions. 


\section{Chapter Seven}

\section{Experimental}

\section{General Considerations}

Unless otherwise stated, all chemistry was performed in a dry $\mathrm{N}_{2}$ atmosphere using either a conventional nitrogen glovebox or Schlenk-line and cannula techniques. Solvents were dried using a Puresolv. System (Innovative Technologies). hppH was purified by sublimation before use and all other reagents were used as received from Sigma-Aldrich. NMR spectra were recorded in either $\mathrm{C}_{6} \mathrm{D}_{6}$ or $\mathrm{CD}_{3} \mathrm{CN}$ on a Varian INOVA system at $298 \mathrm{~K}-300 \mathrm{MHz}$ or $600 \mathrm{MHz}$ for ${ }^{1} \mathrm{H}$, $150 \mathrm{MHz}$ for ${ }^{13} \mathrm{C}$ and $120 \mathrm{MHz}$ for ${ }^{31} \mathrm{P}$ (as specified). All ${ }^{1} \mathrm{H}$ and ${ }^{13} \mathrm{C}$ NMR shifts are referenced internally to residual solvent resonances. Elemental analyses were performed by S. Boyer at London Metropolitan University. 


\section{Experimental Detail for Chapter 2}

\section{Modified Synthesis of $\mathrm{Ph}\left(\mathrm{CH}_{2} \mathrm{hpp}\right)^{65}$}<smiles>c1ccc(CN2CCCN3CCCN=C32)cc1</smiles>

2

A suspension of $95 \% \mathrm{NaH}\left(5.39 \times 10^{-3} \mathrm{~mol}, 0.136 \mathrm{~g}\right)$ in THF $(\sim 20$ $\mathrm{mL}$ ) and a catalytic amount of $\mathrm{KtBuO}$ were added to a solution of hppH $\left(0.75 \mathrm{~g}, 5.39 \times 10^{-3} \mathrm{~mol}\right)$ in THF $(\sim 20 \mathrm{~mL})$. The reaction was heated to $55^{\circ} \mathrm{C}$ for 16 hours. Benzyl bromide $(0.64 \mathrm{~mL}$, $5.39 \times 10^{-3} \mathrm{~mol}$ ) was added to the frothy white suspension which then formed a yellow suspension. The THF was removed in vacuo 16 hours later. The compound was redissolved in toluene and $\mathrm{NaBr}$ was removed by filtration. The toluene was removed in vacuo, yielding a yellow oil. ${ }^{1} \mathrm{H}$ NMR data was obtained to check purity. Yield: $0.9145 \mathrm{~g}, 74 \%$

${ }^{1} \mathrm{H}$ NMR $\left(\mathrm{C}_{6} \mathrm{D}_{6}, 600 \mathrm{MHz}\right) \delta 7.41\left(\mathrm{~d}, \mathrm{~J}_{\mathrm{HH}}=7.0 \mathrm{~Hz}, 2 \mathrm{H}, \mathrm{H}-3\right), 7.19$ (overlapping with solvent peak, m, H-2), $7.08\left(\mathrm{t}, \mathrm{J}_{\mathrm{HH}}=7.3 \mathrm{~Hz}, 1 \mathrm{H}, \mathrm{H}-1\right), 4.84(\mathrm{~s}, 2 \mathrm{H}, \mathrm{H}-5), 3.62$ (pseudot, $2 \mathrm{H}, \mathrm{H}-12$ ), 2.71 (overlapping pseudo-t, $4 \mathrm{H}, \mathrm{H}-10, \mathrm{H}-9$ ), 2.52 (pseudo-t, $2 \mathrm{H}, \mathrm{H}^{-} 7$ ), 1.65 (pseudo-quin, 2H, $\mathrm{H}^{-11}$ ), 1.38 (pseudo-quin, $2 \mathrm{H}, \mathrm{H}-8$ )

\section{Synthesis of $\mathrm{KN}\left\{\mathrm{SiMe}_{3}\right\}_{2} \bullet \mathrm{Ph}\left(\mathrm{CH}_{2} \mathrm{hpp}\right)$}

A yellow solution of $\mathrm{Ph}\left(\mathrm{CH}_{2} \mathrm{hpp}\right)\left(50 \mathrm{mg}, 2.18 \times 10^{-4} \mathrm{~mol}\right)$ in $(\sim 2 \mathrm{~mL})$ of toluene was added to a colourless solution of $\mathrm{KN}\left\{\mathrm{SiMe}_{3}\right\}_{2}\left(43.5 \mathrm{mg}, 2.18 \times 10^{-4} \mathrm{~mol}\right)$ in $(\sim 2 \mathrm{~mL})$ of toluene. The solution turned orange. Attempts at crystallisation via slow evaporation of toluene failed, resulting in the formation of an amorphous solid. Therefore, crystallisation was re-attempted by redissolving the solid in toluene and 
leaving in a freezer at $-30^{\circ} \mathrm{C}$. Block shaped crystals were obtained but were too reactive for collection of X-ray data. Yield 0.0495, 53\%

Note: NMR assignment is based on the numbering in the figure in the $\mathrm{Ph}\left(\mathrm{CH}_{2} \mathrm{hpp}\right)$ ligand preparation. ${ }^{1} \mathrm{H}$ NMR $\left(\mathrm{C}_{6} \mathrm{D}_{6}, 600 \mathrm{MHz}\right) \delta 7.36\left(\mathrm{~d}, \mathrm{~J}_{\mathrm{HH}}=7.5 \mathrm{~Hz}, 2 \mathrm{H}, \mathrm{H}-3\right), 7.20$ $\left(\mathrm{t}, \mathrm{J}_{\mathrm{HH}}=7.6 \mathrm{~Hz}, 2 \mathrm{H}, \mathrm{H}-2\right), 7.09\left(\mathrm{t}, \mathrm{J}_{\mathrm{HH}}=7.3 \mathrm{~Hz}, 1 \mathrm{H}, \mathrm{H}-1\right), 4.73(\mathrm{~s}, 2 \mathrm{H}, \mathrm{H}-5), 3.55$ (pseudo-t, 2H, H-12), 2.67 (overlapping pseudo-t, 4H, H-10, H-9), 2.48 (pseudo-t, 2H, $\mathrm{H}-7$ ), 1.64 (pseudo-quin, 2H, $\mathrm{H}-11$ ), 1.35 (pseudo-quin, $2 \mathrm{H}, \mathrm{H}-8), 0.20$ (s, 36H, $\left.\mathrm{N}\left\{\mathrm{SiMe}_{3}\right\}_{2}\right){ }^{13} \mathrm{C} \mathrm{NMR}\left(\mathrm{C}_{6} \mathrm{D}_{6}, 150 \mathrm{MHz}\right) \delta 150.51(\mathrm{C}-6), 140.16$ (C-4), $127.99(\mathrm{C}-2)$, 127.83 (C-3), 127.67 (C-1), 51.55 (C-5), 48.52 (C-12), 48.37 (C-9), 44.77 (C-7), 44.43 (C-10), $23.62(\mathrm{C}-11), 23.03(\mathrm{C}-8), 7.06(\mathrm{C}-13)$

\section{Synthesis of $\mathrm{LiN}\left\{\mathrm{SiMe}_{3}\right\}_{2} \bullet \mathrm{Ph}\left(\mathrm{CH}_{2} \mathrm{hpp}\right)$}

A yellow solution of $\mathrm{Ph}\left(\mathrm{CH}_{2} \mathrm{hpp}\right)\left(0.1 \mathrm{~g}, 4.36 \times 10^{-4} \mathrm{~mol}\right)$ in toluene $(\sim 5 \mathrm{~mL})$ was added to a colourless solution of $\operatorname{LiN}\left\{\mathrm{SiMe}_{3}\right\}_{2}\left(83 \mathrm{mg}, 4.36 \times 10^{-4} \mathrm{~mol}\right)$ in toluene $(\sim 5$ $\mathrm{mL}$ ). The solution turned deep yellow. Attempts at crystallisation via slow evaporation of toluene failed, resulting in the formation of an amorphous solid. Therefore, crystallisation was re-attempted by redissolving the solid in toluene and leaving in a freezer at $-30^{\circ} \mathrm{C}$ for 16 hours. Needle shaped crystals were obtained but were too reactive for collection of X-ray data. Yield $0.0823 \mathrm{~g}, 47.6 \%$

Note: NMR assignment is based on the numbering in the figure in the $\mathrm{Ph}\left(\mathrm{CH}_{2} \mathrm{hpp}\right)$ ligand preparation. ${ }^{1} \mathrm{H}$ NMR $\left(\mathrm{C}_{6} \mathrm{D}_{6}, 600 \mathrm{MHz}\right) \delta 7.25\left(\mathrm{~d}, \mathrm{~J}_{23}=7.4 \mathrm{~Hz}, 2 \mathrm{H}, \mathrm{H}-3\right), 7.13$ $\left(\mathrm{t}, \mathrm{J}_{\mathrm{HH}}=7.2 \mathrm{~Hz}, 2 \mathrm{H}, \mathrm{H}-2\right), 7.02(\mathrm{~m}, 1 \mathrm{H}, \mathrm{H}-1), 4.58(\mathrm{~s}, 2 \mathrm{H}, \mathrm{H}-5), 3.55$ (pseudo-t, $2 \mathrm{H}$, H-12), 2.67 (overlapping pseudo-t, 4H, H-10, H-9), 2.48 (pseudo-t, 2H, H-7), 1.64 (pseudo-quin, 2H, H-11), 1.35 (pseudo-quin, 2H, H-8), 0.20 (s, 36H, N\{SiMe $\left.\}_{2}\right)^{13} \mathrm{C}$ NMR ( $\left.\mathrm{C}_{6} \mathrm{D}_{6}, 150 \mathrm{MHz}\right) \delta 154.40$ (C-6), 138.26 (C-4), 127.93 (C-2), 127.77 (C-3), 
127.61 (C-1), 53.45 (C-5), 48.20 (C-12), 47.75 (C-9), 44.29 (C-7), 43.60 (C-10), 23.01 (C-11), $22.48(\mathrm{C}-8,5.52(\mathrm{C}-13)$

\section{Synthesis of $\left(\mathrm{NaN}\left\{\mathrm{SiMe}_{3}\right\}_{2}\right)_{2} \bullet 2 \mathrm{Ph}\left(\mathrm{CH}_{2} \mathrm{hpp}\right)$}

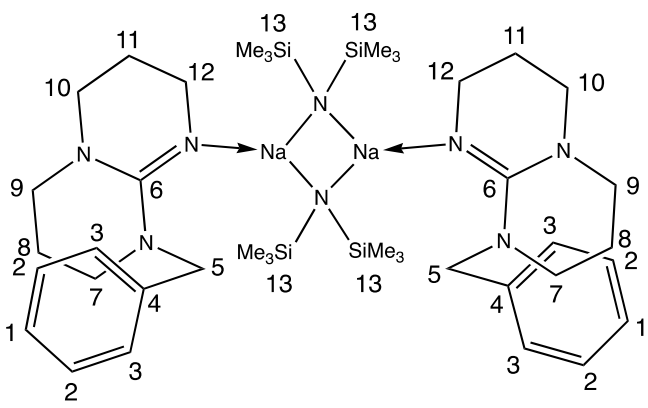

A yellow solution of $\mathrm{Ph}\left(\mathrm{CH}_{2} \mathrm{hpp}\right)(33 \mathrm{mg}$, $\left.1.47 \times 10^{-4} \mathrm{~mol}\right)$ in toluene $(\sim 5 \mathrm{~mL})$ was added to a colourless solution of $\mathrm{NaN}\left\{\mathrm{SiMe}_{3}\right\}_{2}(27$ $\left.\mathrm{mg}, 1.47 \times 10^{-4} \mathrm{~mol}\right)$ in toluene $(\sim 5 \mathrm{~mL})$. The solution turned yellow. Slow evaporation of the toluene yielded small block shaped colourless crystals, surrounded in a small amount of brown oil. X-ray data and NMR data was collected for the crystals. Yield: $0.0513 \mathrm{~g}, 84.6 \%$

Anal. Calcd. for $\mathrm{C}_{40} \mathrm{H}_{74} \mathrm{~N}_{8} \mathrm{Na}_{2} \mathrm{Si}_{4}$ (557.12): C, 38.81; H, 12.66; N, $20.11 \%$. Found C, $50.6 ; \mathrm{H}, 6.29 ; \mathrm{N}, 11.6 \%$ Elemental analysis differences are likely from decomposition of the product

${ }^{1} \mathrm{H}$ NMR $\left(\mathrm{C}_{6} \mathrm{D}_{6}, 600 \mathrm{MHz}\right) \delta 7.39\left(\mathrm{~d}, \mathrm{~J}_{\mathrm{HH}}=7.5 \mathrm{~Hz}, 4 \mathrm{H}, \mathrm{H}-3\right), 7.19\left(\mathrm{t}, \mathrm{J}_{\mathrm{HH}}=7.7 \mathrm{~Hz}, 4 \mathrm{H}\right.$, $\mathrm{H}-2), 7.08\left(\mathrm{t}, \mathrm{J}_{\mathrm{HH}}=7.3 \mathrm{~Hz}, 2 \mathrm{H}, \mathrm{H}-1\right), 4.79(\mathrm{~s}, 4 \mathrm{H}, \mathrm{H}-5), 3.60$ (pseudo-t, 4H, H-12), 2.67 (overlapping pseudo-t, $8 \mathrm{H}, \mathrm{H}-10, \mathrm{H}-9$ ), 2.45 (pseudo-t, $4 \mathrm{H}, \mathrm{H}-7$ ), 1.65 (pseudoquin, $4 \mathrm{H}, \mathrm{H}-11), 1.31$ (pseudo-quin, $4 \mathrm{H}, \mathrm{H}-8), 0.26(\mathrm{~s}, 36 \mathrm{H}, \mathrm{H}-13){ }^{13} \mathrm{C} \mathrm{NMR}\left(\mathrm{C}_{6} \mathrm{D}_{6}\right.$, $150 \mathrm{MHz}) \delta 127.93(\mathrm{C}-2), 127.77$ (C-3), $127.61(\mathrm{C}-1), 51.67$ (C-5), $48.43(\mathrm{C}-12), 48.24$ (C-9), 44.47 (C-7), 44.41 (C-10), 23.57 (C-11), 22.93 (C-8), 6.67 (C-13) Note: C-4 and C-6 resonances not observed in ${ }^{13} \mathrm{C}$ NMR 


\section{Modified Synthesis of $1,2-\left(\mathrm{CH}_{2} \mathrm{hpp}\right)_{2}-\mathrm{C}_{6} \mathrm{H}_{4}{ }^{65}$}

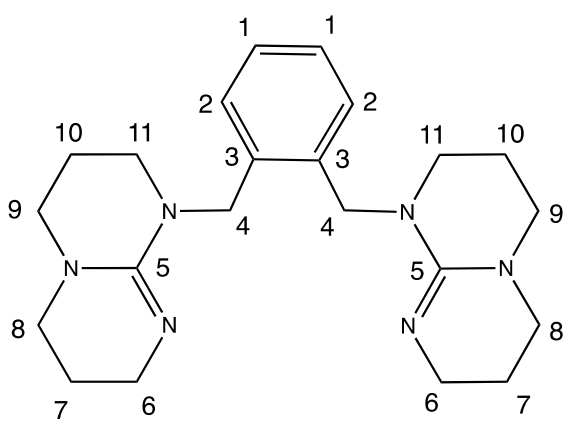

A suspension of $95 \% \mathrm{NaH}\left(0.0862 \mathrm{~g}, 3.59 \times 10^{-3}\right.$ mol) in THF $(\sim 20 \mathrm{~mL})$ and a catalytic amount of $\mathrm{KtBuO}$ was added to a solution of $\mathrm{hppH}(0.5 \mathrm{~g}$, $\left.3.59 \times 10^{-3} \mathrm{~mol}\right)$ in THF $(\sim 20 \mathrm{~mL})$. The reaction was heated to $55^{\circ} \mathrm{C}$ for 16 hours. A solution of $\alpha, \alpha^{\prime}$-dibromo- $\sigma^{-x y l e n e}\left(0.474 \mathrm{~g}, 1.796 \times 10^{-3} \mathrm{~mol}\right)$ in THF $(\sim 20 \mathrm{~mL})$ was added to the frothy white suspension which then formed a yellow suspension. The THF was removed in vacuo 16 hours later. The compound was redissolved in toluene and $\mathrm{NaBr}$ was removed by filtration. The toluene was removed in vacuo, yielding a yellow solid. ${ }^{1} \mathrm{H}$ NMR data was obtained to check purity. Yield $1.0232 \mathrm{~g}, 74.9 \%{ }^{1} \mathrm{H}$ $\operatorname{NMR}\left(\mathrm{C}_{6} \mathrm{D}_{6}, 600 \mathrm{MHz}\right) \delta 7.48\left(\mathrm{dd}, \mathrm{J}_{\mathrm{HH}}=5.5,3.5 \mathrm{~Hz}, 2 \mathrm{H}, \mathrm{H}-2\right), 7.18\left(\mathrm{dd}, \mathrm{J}_{\mathrm{HH}}=5.6\right.$, $3.4 \mathrm{~Hz}, 2 \mathrm{H}, \mathrm{H}-1), 5.05(\mathrm{~s}, 4 \mathrm{H}, \mathrm{H}-4), 3.62$ (pseudo-t, 4H, H-6), 2.72 (overlapping pseudo-t, 8H, H-8, H-9), 2.54 (pseudo-t, 4H, H-11), 1.65 (pseudo-quin, 4H, H-7), 1.40 (pseudo-quin, $4 \mathrm{H}, \mathrm{H}-10$ )

\section{$\mathrm{LiN}\left\{\mathrm{SiMe}_{3}\right\}_{2} \bullet 1,2-\left(\mathrm{CH}_{2} \mathrm{hpp}\right)_{2}-\mathrm{C}_{6} \mathrm{H}_{4}$}

A yellow solution of $1,2^{-}\left(\mathrm{CH}_{2} \mathrm{hpp}\right)_{2}-\mathrm{C}_{6} \mathrm{H}_{4}\left(57 \mathrm{mg}, 1.49 \times 10^{-4} \mathrm{~mol}\right)$ in $\mathrm{C}_{6} \mathrm{D}_{6}(\sim 0.3 \mathrm{~mL})$ was added to a colourless solution of $\mathrm{LiN}\left\{\mathrm{SiMe}_{3}\right\}_{2}\left(83 \mathrm{mg}, 4.36 \times 10^{-4} \mathrm{~mol}\right)$ in $\mathrm{C}_{6} \mathrm{D}_{6}$ ( $\sim 0.3 \mathrm{~mL})$. The solution turned deep yellow. No crystallisation occurred in the NMR tube so the $\mathrm{C}_{6} \mathrm{D}_{6}$ was removed by evaporation in vacuo. The compound was redissolved in toluene in an unsuccessful crystallisation attempt. ${ }^{1} \mathrm{H}-\mathrm{NMR}$ data was obtained for a dried aliquot of the resultant yellow solution. No yield obtained as product did not crystallise. 
Note: NMR assignment is based on the numbering in the figure in the $1,2^{-}$ $\left(\mathrm{CH}_{2} \mathrm{hpp}\right)_{2}-\mathrm{C}_{6} \mathrm{H}_{4}$ ligand preparation. ${ }^{1} \mathrm{H} \mathrm{NMR}\left(\mathrm{C}_{6} \mathrm{D}_{6}, 300 \mathrm{MHz}\right) \delta 7.26(\mathrm{~m}, 2 \mathrm{H}, \mathrm{H}-2)$, 7.15 (m, 2H, H-1), 4.79 (s, 4H, H-4), 3.66 (br s, 4H, H-6), 2.79 (pseudo-t, 4H, H-8), 2.69 (pseudo-t, 4H, H-9), 2.52 (pseudo-t, 4H, H-11), 1.67 (pseudo-quin, 4H, H-7),

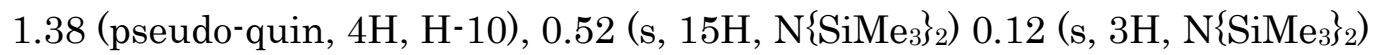

\section{$\mathrm{NaN}\left\{\mathrm{SiMe}_{3}\right\}_{2} \bullet 1,2-\left(\mathrm{CH}_{2} \mathrm{hpp}\right)_{2}-\mathrm{C}_{6} \mathrm{H}_{4}$}

A yellow solution of $1,2^{-}\left(\mathrm{CH}_{2} \mathrm{hpp}\right)_{2}-\mathrm{C}_{6} \mathrm{H}_{4}\left(52 \mathrm{mg}, 1.36 \times 10^{-4} \mathrm{~mol}\right)$ in $\mathrm{C}_{6} \mathrm{D}_{6}(\sim 0.3 \mathrm{~mL})$ was added to a colourless solution of $\mathrm{NaN}\left\{\mathrm{SiMe}_{3}\right\}_{2}\left(25 \mathrm{mg}, 1.36 \times 10^{-4} \mathrm{~mol}\right)$ in $\mathrm{C}_{6} \mathrm{D}_{6}$ $(\sim 0.3 \mathrm{~mL}) .{ }^{1} \mathrm{H}-\mathrm{NMR}$ data was obtained for the orange solution. Small crystals formed in the NMR tube but could not be retrieved. The $\mathrm{C}_{6} \mathrm{D}_{6}$ was removed by evaporation in vacuo. Attempts to redissolve the resultant solid in toluene then toluene/THF then THF, all caused white powder to precipitate. No crystalline material was obtained so no yield was obtained.

Note: NMR assignment is based on the numbering in the figure in the $1,2^{-}$ $\left(\mathrm{CH}_{2} \mathrm{hpp}\right)_{2}-\mathrm{C}_{6} \mathrm{H}_{4}$ ligand preparation. ${ }^{1} \mathrm{H} \mathrm{NMR}\left(\mathrm{C}_{6} \mathrm{D}_{6}, 300 \mathrm{MHz}\right) \delta 7.44(\mathrm{~m}, 2 \mathrm{H}, \mathrm{H}-2)$, 7.16 (overlapping with solvent peak, m, H-1), 4.93 (s, 4H, H-4), 3.58 (br s, 4H, H6), 2.73 (br s, 8H, H-8, H-9), 2.54 (br s, 4H, H-11), 1.64 (br s, 4H, H-7), 1.40 (br s, $4 \mathrm{H}, \mathrm{H}-10), 0.43\left(\mathrm{~s}, 3 \mathrm{H}, \mathrm{N}\left\{\mathrm{SiMe}_{3}\right\}_{2}\right), 0.09$ (s, 15H, N\{SiMe$\left.\}_{2}\right)$

\section{$\mathrm{KN}\left\{\mathrm{SiMe}_{3}\right\}_{2} \bullet 1,2-\left(\mathrm{CH}_{2} \mathrm{hpp}\right)_{2}-\mathrm{C}_{6} \mathrm{H}_{4}$}

A yellow solution of $1,2-\left(\mathrm{CH}_{2} \mathrm{hpp}\right)_{2}-\mathrm{C}_{6} \mathrm{H}_{4}\left(48 \mathrm{mg}, 1.25 \times 10^{-4} \mathrm{~mol}\right)$ in $\mathrm{C}_{6} \mathrm{D}_{6}(\sim 0.3 \mathrm{~mL})$ was added to a colourless solution of $\mathrm{KN}\left\{\mathrm{SiMe}_{3}\right\}_{2}\left(25 \mathrm{mg}, 1.25 \times 10^{-4} \mathrm{~mol}\right)$ in $\mathrm{C}_{6} \mathrm{D}_{6}$ ( $\sim 0.3 \mathrm{~mL}) .{ }^{1} \mathrm{H}-\mathrm{NMR}$ data was obtained for the yellow solution. Large colourless 
single crystals formed from the yellow solution without the need for recrystallization attempts. X-ray data was obtained for the crystals. The NMR scale reaction was too small to obtain a yield so the reaction was scaled up and repeated. $1,2-\left(\mathrm{CH}_{2} \mathrm{hpp}\right)_{2}-\mathrm{C}_{6} \mathrm{H}_{4}\left(0.15 \mathrm{~g}, 3.9 \times 10^{-4} \mathrm{~mol}\right)$ in $3 \mathrm{~mL}$ of toluene and $\mathrm{KN}\left\{\mathrm{SiMe}_{3}\right\}_{2}\left(0.0786 \mathrm{~g}, 3.9 \times 10^{-4} \mathrm{~mol}\right)$ in $3 \mathrm{~mL}$ of toluene. Yield $0.2128 \mathrm{~g}, 94 \%$ Anal. Calcd. for $\mathrm{C}_{34} \mathrm{H}_{56} \mathrm{~N}_{7} \mathrm{KSi}_{2}$ (658.12): C, 62.05; H, 8.58; N, $14.90 \%$. Found C, 45.14; H, $7.20 ; \mathrm{N}, 7.38 \%$ Elemental analysis differences are likely from decomposition of the product.

Note: NMR assignment is based off the numbering on the figure in the $1,2^{-}$ $\left(\mathrm{CH}_{2} \mathrm{hpp}\right)_{2}-\mathrm{C}_{6} \mathrm{H}_{4}$ ligand preparation. ${ }^{1} \mathrm{H} \mathrm{NMR}\left(\mathrm{C}_{6} \mathrm{D}_{6}, 600 \mathrm{MHz}\right) \delta 7.25(\mathrm{~m}, 2 \mathrm{H}, \mathrm{H}-2)$, 7.15 (m, 2H, H-1), 4.47 (br s, 4H, H-4), 3.50 (br s, 4H, H-6), 2.75 (pseudo-t, 4H, H8), 2.65 (pseudo-t, 4H, H-9), 2.51 (pseudo-t, 4H, H-11), 1.60 (pseudo-quin, 4H, $\mathrm{H}^{-}$

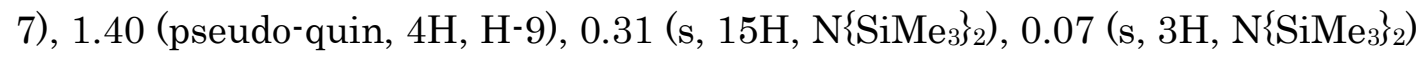

\section{Modified Synthesis of 1,3-( $\left.\mathrm{CH}_{2} \mathrm{hpp}\right)_{2}-\mathrm{C}_{6} \mathrm{H}_{4} 65$}

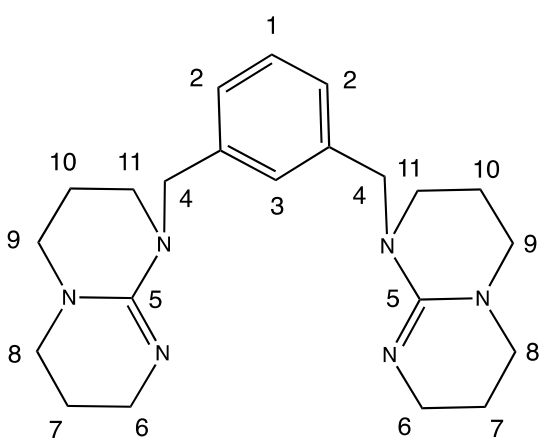

A suspension of $95 \% \mathrm{NaH}\left(0.0862 \mathrm{~g}, 3.59 \times 10^{-3}\right.$ mol) in THF $(\sim 20 \mathrm{~mL})$ and a catalytic amount of $\mathrm{KtBuO}$ were added to a solution of hppH $(0.5 \mathrm{~g}$, $\left.3.59 \times 10^{-3} \mathrm{~mol}\right)$ in THF $(\sim 20 \mathrm{~mL})$. The reaction was heated to $55^{\circ} \mathrm{C}$ for 16 hours. A solution of $\alpha, \alpha^{\prime}-$ dibromo- $m$-xylene $\left(0.474 \mathrm{~g}, 1.796 \times 10^{-3} \mathrm{~mol}\right)$ in THF $(\sim 20 \mathrm{~mL})$ was added to the frothy white suspension which then formed a yellow suspension. The THF was removed in vacuo 16 hours later. The compound was redissolved in toluene and $\mathrm{NaBr}$ was removed by filtration. The toluene was removed in vacuo, yielding a yellow solid. ${ }^{1} \mathrm{H}$ NMR data was obtained to check purity. Yield $1.1106 \mathrm{~g}, 81.3 \%{ }^{1} \mathrm{H}$ $\operatorname{NMR}\left(\mathrm{C}_{6} \mathrm{D}_{6}, 300 \mathrm{MHz}\right) \delta 7.49(\mathrm{~s}, 1 \mathrm{H}, \mathrm{H}-3), 7.35\left(\mathrm{~d}, \mathrm{~J}_{\mathrm{HH}}=7.4 \mathrm{~Hz}, 2 \mathrm{H}, \mathrm{H}-2\right), 7.23(\mathrm{t}$, 
$\left.\mathrm{J}_{\mathrm{HH}}=7.4 \mathrm{~Hz}, 1 \mathrm{H}, \mathrm{H}-1\right), 4.89(\mathrm{~s}, 4 \mathrm{H}, \mathrm{H}-4), 3.64$ (pseudo-t, $\left.4 \mathrm{H}, \mathrm{H}-6\right), 2.75$ (overlapping pseudo-t, 8H, H-8, H-9), 2.56 (pseudo-t, 4H, H-11), 1.67 (pseudo-quin, 4H, H-7), 1.43 (pseudo-quin, 4H, $\mathrm{H}-10$ )

\section{$\mathrm{KN}\left\{\mathrm{SiMe}_{3}\right\}_{2} \bullet 1,3-\left(\mathrm{CH}_{2} \mathrm{hpp}\right)_{2}-\mathrm{C}_{6} \mathrm{H}_{4}$}

A solution of yellow solution of $1,3-\left(\mathrm{CH}_{2} \mathrm{hpp}\right)_{2}-\mathrm{C}_{6} \mathrm{H}_{4}\left(20 \mathrm{mg}, 5.26 \times 10^{-5} \mathrm{~mol}\right)$ in $\mathrm{C}_{6} \mathrm{D}_{6}$ $(\sim 0.3 \mathrm{~mL})$ was added to a colourless solution of $\mathrm{KN}\left\{\mathrm{SiMe}_{3}\right\}_{2}\left(10 \mathrm{mg}, 5.26 \times 10^{-5} \mathrm{~mol}\right)$ in $\mathrm{C}_{6} \mathrm{D}_{6}(\sim 0.3 \mathrm{~mL})$ in an NMR tube. The solution stayed yellow and ${ }^{1} \mathrm{H}$ NMR data was obtained. The product was crystallised by slow evaporation of toluene at room temperature. The crystals obtained were suitable for X-ray diffraction studies. Yield: 0.0144 g, 47.2\%

Note: NMR assignment is based on the numbering in the figure in the $1,3^{-}$ $\left(\mathrm{CH}_{2} \mathrm{hpp}\right)_{2}-\mathrm{C}_{6} \mathrm{H}_{4}$ ligand preparation. ${ }^{1} \mathrm{H}$ NMR $\left(\mathrm{C}_{6} \mathrm{D}_{6}, 300 \mathrm{MHz}\right) \delta 7.37(\mathrm{~s}, 1 \mathrm{H}, \mathrm{H}-3)$, 7.25 (br s, 2H, H-2), 7.16 (br s, 1H, H-1), 4.72 (s, 4H, H-4), 3.55 (pseudo-t, 4H, H6), 2.72 (overlapping pseudo-t, 8H, H-8, H-9), 2.53 (pseudo-t, 4H, H-11), 1.65 (pseudo-quin, 4H, H-7), 1.42 (pseudo-quin, 4H, H-10), 0.22 (s, 24H, N\{SiMe $\}_{2}$ ). 


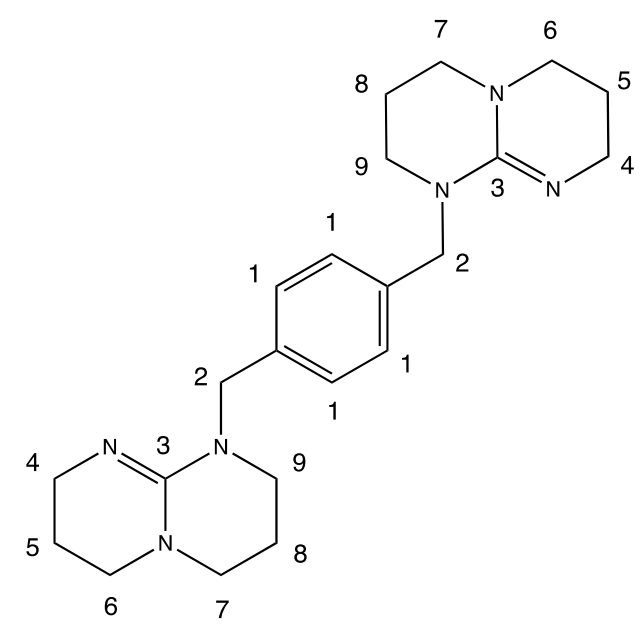

A suspension of $95 \% \mathrm{NaH}\left(0.0862 \mathrm{~g}, 3.59 \times 10^{-3}\right.$ $\mathrm{mol})$ in THF $(\sim 20 \mathrm{~mL})$ and a catalytic amount of $\mathrm{KtBuO}$ was added to a solution of hppH (0.5 $\left.\mathrm{g}, 3.59 \times 10^{-3} \mathrm{~mol}\right)$ in THF $(\sim 20 \mathrm{~mL})$. The reaction was heated to $55^{\circ} \mathrm{C}$ for 16 hours. A solution of $\alpha, \alpha^{\prime}$-dibromo- $p$-xylene $(0.474 \mathrm{~g}$, $\left.1.796 \times 10^{-3} \mathrm{~mol}\right)$ in THF $(\sim 20 \mathrm{~mL})$ was added to the frothy white suspension which then formed a yellow suspension. The THF was removed in vacuo 16 hours later. The compound was redissolved in toluene and $\mathrm{NaBr}$ was removed by filtration. The toluene was removed in vacuo, yielding a yellow solid. ${ }^{1} \mathrm{H}$ NMR data was obtained to check purity. Yield $1.048 \mathrm{~g}, 76.7 \%{ }^{1} \mathrm{H}$ NMR ( $\left.\mathrm{C}_{6} \mathrm{D}_{6}, 300 \mathrm{MHz}\right) \delta 7.43\left(\mathrm{~s}, 4 \mathrm{H}, \mathrm{H}^{-1}\right), 4.87$ (s, 4H, H-2), 3.64 (pseudo-t, 4H, H4), 2.73 (overlapping pseudo-t, 8H, H-6, H-7), 2.53 (pseudo-t, 4H, H-9), 1.66 (pseudo-quin, 4H, H-5), 1.40 (pseudo-quin, 4H, H-8)

\section{Synthesis of $\mathrm{KN}\left\{\mathrm{SiMe}_{3}\right\}_{2} \bullet 1,4-\left(\mathrm{CH}_{2} \mathrm{hpp}\right)_{2}-\mathrm{C}_{6} \mathrm{H}_{4}$}

A solution of $1,4-\left(\mathrm{CH}_{2} \mathrm{hpp}\right)_{2}-\mathrm{C}_{6} \mathrm{H}_{4}\left(30 \mathrm{mg}, 7.89 \times 10^{-5} \mathrm{~mol}\right)$ in $\mathrm{C}_{6} \mathrm{D}_{6}(\sim 0.3 \mathrm{~mL})$ was added to a solution of $\mathrm{KN}\left\{\mathrm{SiMe}_{3}\right\}_{2}\left(16 \mathrm{mg}, 7.89 \times 10^{-5} \mathrm{~mol}\right)$ in $\mathrm{C}_{6} \mathrm{D}_{6}(\sim 0.3 \mathrm{~mL})$. A white precipitate formed in the NMR tube. ${ }^{1} \mathrm{H}$ NMR data was still obtained of the soluble fraction of the reaction. Recrystallization attempts in toluene were unsuccessful so no yield was obtained.

Note: NMR assignment is based on the numbering in the figure in the $1,4^{-}$ $\left(\mathrm{CH}_{2} \mathrm{hpp}\right)_{2}-\mathrm{C}_{6} \mathrm{H}_{4}$ ligand preparation. ${ }^{1} \mathrm{H}$ NMR $\left(\mathrm{C}_{6} \mathrm{D}_{6}, 300 \mathrm{MHz}\right) \delta 7.37(\mathrm{~s}, 4 \mathrm{H}, \mathrm{H}-1)$, 
$4.73(\mathrm{~s}, 4 \mathrm{H}, \mathrm{H}-2), 3.56$ (pseudo-t, $4 \mathrm{H}, \mathrm{H}-4), 2.70$ (overlapping pseudo-t, $8 \mathrm{H}, \mathrm{H}-6, \mathrm{H}^{-}$ 7), 2.50 (pseudo-t, 4H, H-8), 1.64 (pseudo-quin, 4H, H-5), 1.48 (pseudo-quin, 4H, H8), $0.19\left(\mathrm{~s}, 36 \mathrm{H}, \mathrm{N}\left\{\mathrm{SiMe}_{3}\right\}_{2}\right)$

\section{Modified Synthesis of 1,3,5-( $\left(\mathrm{CH}_{2} \mathrm{hpp}\right)_{3}-\mathrm{C}_{6} \mathrm{H}_{3}{ }^{65}$}

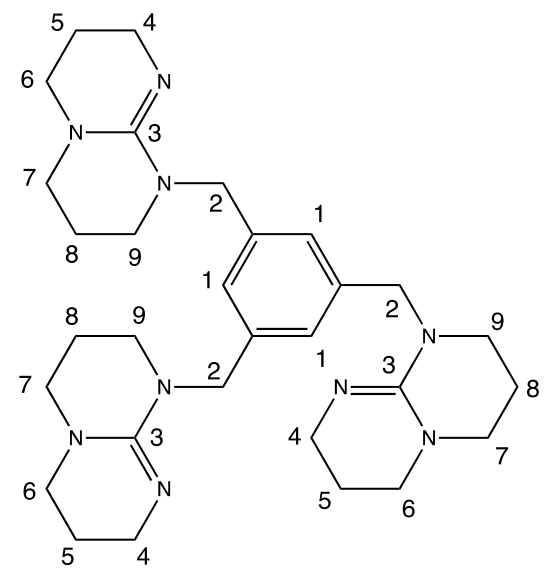

A suspension of $95 \% \mathrm{NaH}\left(0.1723 \mathrm{~g}, 7.18 \times 10^{-3} \mathrm{~mol}\right)$ in THF $(\sim 20 \mathrm{~mL})$ and a catalytic amount of $\mathrm{KtBuO}$ were added to a solution of hppH $\left(1 \mathrm{~g}, 7.18 \times 10^{-3}\right.$ $\mathrm{mol})$ in THF $(\sim 40 \mathrm{~mL})$. The reaction was heated to $55^{\circ} \mathrm{C}$ for 16 hours. A solution of $1,3,5^{-}$ tris(bromomethyl)benzene $\left(0.854 \mathrm{~g}, 2.39 \times 10^{-3} \mathrm{~mol}\right)$ in THF ( 20 mL) was added to the frothy white suspension which then formed a yellow suspension. The THF was removed in vacuo 16 hours later. The compound was redissolved in toluene and $\mathrm{NaBr}$ was removed by filtration. The toluene was removed in vacuo, yielding a yellow solid. ${ }^{1} \mathrm{H}$ NMR data was obtained to check purity. Yield $2.553 \mathrm{~g}, 67.8 \%{ }^{1} \mathrm{H}$ NMR $\left(\mathrm{C}_{6} \mathrm{D}_{6}\right.$, $300 \mathrm{MHz}) \delta 7.41(\mathrm{~s}, 3 \mathrm{H}, \mathrm{H}-1), 4.92(\mathrm{~s}, 6 \mathrm{H}, \mathrm{H}-2), 3.65$ (pseudo-t, 6H, H-4), 2.79 (overlapping pseudo-t, 12H, H-6, H-7), 2.59 (pseudo-t, 6H, H-9), 1.70 (pseudo-quin, $6 \mathrm{H}, \mathrm{H}-5$ ), 1.48 (pseudo-quin, 6H, $\mathrm{H}-8$ )

\section{Synthesis of $\mathrm{KN}\left\{\mathrm{SiMe}_{3}\right\}_{2} \bullet 1,3,5-\left(\mathrm{CH}_{2} \mathrm{hpp}\right)_{3}-\mathrm{C}_{6} \mathrm{H}_{3}$}

A solution of $1,3,5-\left(\mathrm{CH}_{2} \mathrm{hpp}\right)_{3}-\mathrm{C}_{6} \mathrm{H}_{3}\left(0.1 \mathrm{~g}, 1.88 \times 10^{-4} \mathrm{~mol}\right)$ in toluene $(\sim 3 \mathrm{~mL})$ was added to a solution of $\mathrm{KN}\left\{\mathrm{SiMe}_{3}\right\}_{2}\left(38 \mathrm{mg}, 1.88 \times 10^{-4} \mathrm{~mol}\right)$ in toluene $(\sim 3 \mathrm{~mL})$. Crystallisation (by slow evaporation of toluene at RT) was attempted but no crystals large enough for single crystal X-ray diffraction were produced. A yield 
and ${ }^{1} \mathrm{H}$ NMR data was obtained from the amorphous solid produced. Yield $0.1256 \mathrm{~g}$, $91.4 \%$

Note: NMR assignment is based on the numbering in the figure in the $1,3,5^{-}$ $\left(\mathrm{CH}_{2} \mathrm{hpp}\right)_{3}{ }^{-} \mathrm{C}_{6} \mathrm{H}_{3}$ ligand preparation. ${ }^{1} \mathrm{H} \mathrm{NMR}(\mathrm{C} 6 \mathrm{D} 6,300 \mathrm{MHz}) \delta 7.20(\mathrm{~s}, 3 \mathrm{H}, \mathrm{H}-1)$, 4.68 (s, $6 \mathrm{H}, \mathrm{H}-2$ ), 3.53 (pseudo-t, $6 \mathrm{H}, \mathrm{H}-4$ ), 2.79 (overlapping pseudo-t, $12 \mathrm{H}, \mathrm{H}-6$, $\mathrm{H}^{-7}$ ), 2.59 (pseudo-t, 6H, H-9), 1.66 (pseudo-quin, 6H, H-5), 1.51 (pseudo-quin, $6 \mathrm{H}$, $\mathrm{H}-8), 0.31\left(\mathrm{~s}, 18 \mathrm{H}, \mathrm{N}\left\{\mathrm{SiMe}_{3}\right\}_{2}\right)$

\section{Experimental Detail from Chapter 3}

\section{1,2-( $\left(\mathrm{CH}_{2} \mathrm{hpp}\right)_{2}-\mathrm{C}_{6} \mathrm{H}_{4}$ ligand (in $\mathrm{CD}_{3} \mathrm{CN}$ as opposed to $\mathrm{C}_{6} \mathrm{D}_{6}$ )}

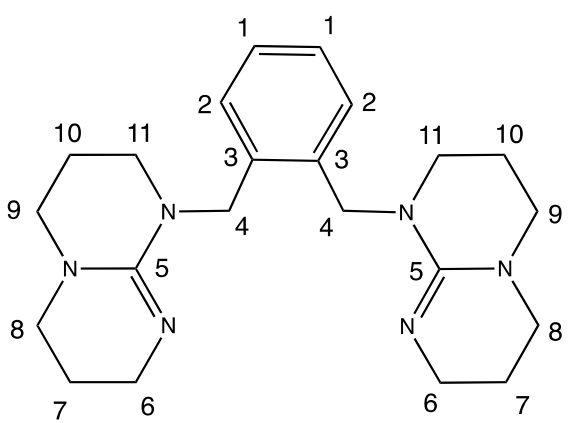

As $\mathrm{CD}_{3} \mathrm{CN}$ was used regularly as described throughout this chapter, the assignment of the ${ }^{1} \mathrm{H}$ NMR for the $1,2-\left(\mathrm{CH}_{2} \mathrm{hpp}\right)_{2}-\mathrm{C}_{6} \mathrm{H}_{4}$ ligand is as follows: ${ }^{1} \mathrm{H}$ NMR $\left(\mathrm{CD}_{3} \mathrm{CN}, 300 \mathrm{MHz}\right) \delta 7.22(\mathrm{~s}, 4 \mathrm{H}$, $\mathrm{H}-1, \mathrm{H}-2), 4.54(\mathrm{~s}, 4 \mathrm{H}, \mathrm{H}-4), 3.26$ (pseudo-t, $4 \mathrm{H}$, H-6) 3.15 (overlapping pseudo-t, 8H, H-8, H-9), 3.06 (pseudo-t, 4H, H-11), 1.94 (pseudo-quin, 4H, H-7), 1.79 (pseudo-quin, 4H, $\mathrm{H}^{-10}$ ) 


\section{1,3-( $\left(\mathrm{CH}_{2} \mathrm{hpp}\right)_{2}-\mathrm{C}_{6} \mathrm{H}_{4}$ ligand (in $\mathrm{CD}_{3} \mathrm{CN}$ as opposed to $\mathrm{C}_{6} \mathrm{D}_{6}$ )}

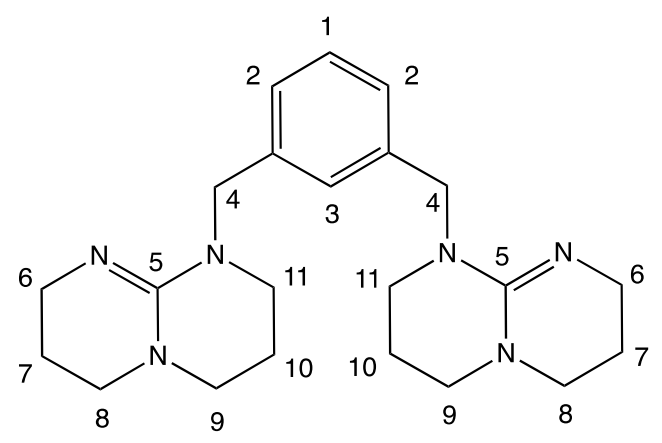

(s, 1H, H-3), $7.10\left(\mathrm{~d}, \mathrm{~J}_{\mathrm{HH}}=7.3 \mathrm{~Hz}, 2 \mathrm{H}, \mathrm{H}-2\right), 4.56(\mathrm{~s}, 4 \mathrm{H}, 4 \mathrm{H}, \mathrm{H}-4), 3.28$ (pseudo-t, 4H, H-6), 3.15 (overlapping pseudo-t, 8H, H-8, H-9), 3.09 (pseudo-t, 4H, H-11), 1.94 (pseudo-quin, 4H, H-7), 1.79 (pseudo-quin, 4H, H-10)

\section{Attempted Synthesis of $\mathrm{BiPh}_{3} \bullet 1,2-\left(\mathrm{CH}_{2} \mathrm{hpp}\right)_{2}-\mathrm{C}_{6} \mathrm{H}_{4}$}

A yellow solution of $1,2-\left(\mathrm{CH}_{2} \mathrm{hpp}\right)_{2}-\mathrm{C}_{6} \mathrm{H}_{4}\left(20 \mathrm{mg}, 5.25 \times 10^{-4} \mathrm{~mol}\right)$ in $\mathrm{C}_{6} \mathrm{D}_{6}(\sim 0.3 \mathrm{~mL})$ was added to a colourless solution of $\mathrm{BiPh}_{3}\left(23 \mathrm{mg}, 5.25 \times 10^{-4} \mathrm{~mol}\right)$ in $\mathrm{C}_{6} \mathrm{D}_{6}(\sim 0.3$ mL). ${ }^{1} \mathrm{H}-\mathrm{NMR}$ data was collected which indicated no coordination had occurred as the resonances from the ligand had not shifted. The sample was heated to $60^{\circ} \mathrm{C}$ and ${ }^{1} \mathrm{H}-\mathrm{NMR}$ data was collected again. ${ }^{1} \mathrm{H}-\mathrm{NMR}$ data was the same as that for the 1,2-( $\left.\mathrm{CH}_{2} \mathrm{hpp}\right)_{2}-\mathrm{C}_{6} \mathrm{H}_{4}$ ligand both before and after heating.

\section{Synthesis of $\mathrm{BiCl}_{2} \mathrm{Ph}$}

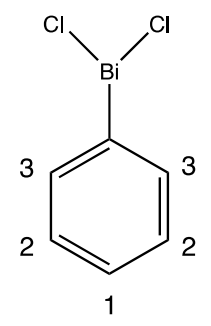

A solution of $\mathrm{BiPh}_{3}\left(0.349 \mathrm{~g}, 7.93 \times 10^{-4} \mathrm{~mol}\right)$ in diethyl ether $(\sim 10 \mathrm{~mL})$ was added to $\mathrm{BiCl}_{3}\left(0.5 \mathrm{~g}, 1.59 \times 10^{-3} \mathrm{~mol}\right)$. A cream-yellow precipitate formed and the reaction was left stirring for 5 days. Diethyl ether was 
evaporated in vacuo. ${ }^{1} \mathrm{H}$ NMR data was collected for the sample. Yield $0.8219 \mathrm{~g}$, $96.8 \%$

${ }^{1} \mathrm{H}$ NMR $\left(\mathrm{CD}_{3} \mathrm{CN}, 300 \mathrm{MHz}\right) \delta 8.98\left(\mathrm{~d}, \mathrm{~J}_{\mathrm{HH}}=7.4 \mathrm{~Hz}, 5 \mathrm{H}\right), 8.32\left(\mathrm{~d}, \mathrm{~J}_{\mathrm{HH}}=7.5 \mathrm{~Hz}, 1 \mathrm{H}\right)$, $8.02\left(\mathrm{t}, \mathrm{J}_{\mathrm{HH}}=7.4 \mathrm{~Hz} 5 \mathrm{H}\right), 7.67\left(\mathrm{t}, \mathrm{J}_{\mathrm{HH}}=7.4 \mathrm{~Hz}, 1 \mathrm{H}\right), 7.50\left(\mathrm{t}, \mathrm{J}_{\mathrm{HH}}=7.5 \mathrm{~Hz}, 5 \mathrm{H}\right), 7.40$ $\left(\mathrm{t}, \mathrm{J}_{\mathrm{HH}}=7.2 \mathrm{~Hz}, 1 \mathrm{H}\right)$

\section{Attempted Synthesis of $\mathrm{BiCl}_{2} \mathrm{Ph} \bullet 1,2-\left(\mathrm{CH}_{2} \mathrm{hpp}\right)_{2}-\mathrm{C}_{6} \mathrm{H}_{4}$}

A colourless solution of $\mathrm{BiCl}_{2} \mathrm{Ph}\left(94 \mathrm{mg}, 2.63 \times 10^{-4} \mathrm{~mol}\right)$ in $\mathrm{THF}(\sim 5 \mathrm{~mL})$ was added to the yellow solution of $1,2-\left(\mathrm{CH}_{2} \mathrm{hpp}\right)_{2}-\mathrm{C}_{6} \mathrm{H}_{4}\left(0.1 \mathrm{~g}, 2.63 \times 10^{-4} \mathrm{~mol}\right)$ in $\mathrm{THF}(\sim 5 \mathrm{~mL})$. Immediately, a brown precipitate formed. After $30 \mathrm{~min}$, the THF was removed in vacuo and ${ }^{1} \mathrm{H}$ NMR data obtained on the sparingly soluble brown precipitate in $\mathrm{CD}_{3} \mathrm{CN}$. No crystalline material was obtained due to solubility issues so no yield was recorded.

Note: NMR assignment is based on the numbering in the figure in the $1,2^{-}$ $\left(\mathrm{CH}_{2} \mathrm{hpp}\right)_{2}-\mathrm{C}_{6} \mathrm{H}_{4}$ ligand assignment in $\mathrm{CD}_{3} \mathrm{CN}$ and the $\mathrm{BiCl}_{2} \mathrm{Ph}$ reagent preparation. ${ }^{1} \mathrm{H} \mathrm{NMR}\left(\mathrm{CD}_{3} \mathrm{CN}, 300 \mathrm{MHz}\right) \delta 8.57\left(\mathrm{~d}, \mathrm{~J}_{\mathrm{HH}}=7.2 \mathrm{~Hz}, 1 \mathrm{H}\right), 7.50\left(\mathrm{t}, \mathrm{J}_{\mathrm{HH}}=\right.$ $7.0 \mathrm{~Hz}, 1 \mathrm{H}), 7.29(\mathrm{~m}, 2 \mathrm{H}, \mathrm{H}-2), 7.20(\mathrm{~m}, 2 \mathrm{H}, \mathrm{H}-1), 4.64(\mathrm{~s}, 4 \mathrm{H}, \mathrm{H}-4), 3.24$ (overlapping pseudo-t, 16H, H-6, H-8, H-9, H-11), 1.99 (m, overlapping with solvent peak, $\left.\mathrm{H}^{-} 7\right), 1.85$ (m, 4H, H-10) 
Attempted Synthesis of $\mathrm{SbCl}_{3} \bullet 1,2-\left(\mathrm{CH}_{2} \mathrm{hpp}\right)_{2}-\mathrm{C}_{6} \mathrm{H}_{4}$ consequent synthesis of $\mathrm{Sb}\left[\kappa-\mathrm{C}, \mathrm{N}-1-(\mathrm{CHhpp})-2-\left(\mathrm{CH}_{2} \mathrm{hppH}\right) \mathrm{C}_{6} \mathrm{H}_{4}\right] \mathrm{Cl}_{3}$

A solution of $1,2^{-}\left(\mathrm{CH}_{2} \mathrm{hpp}\right)_{2}-\mathrm{C}_{6} \mathrm{H}_{4}\left(22 \mathrm{mg}, 5.835 \times 10^{-5} \mathrm{~mol}\right)$ dissolved in $\mathrm{C}_{6} \mathrm{D}_{6}(\sim 0.3$ $\mathrm{mL})$ was added to a solution of $\mathrm{SbCl}_{3}\left(13 \mathrm{mg}, 5.835 \times 10^{-5} \mathrm{~mol}\right)$ dissolved in $\mathrm{C}_{6} \mathrm{D}_{6}$ $(\sim 0.3 \mathrm{~mL})$ in an NMR tube. A thick yellow compound immediately precipitated. The sample was transferred to a vial and the volatiles were removed under reduced pressure and $\mathrm{CD}_{3} \mathrm{CN}$ was added. The yellow compound was sufficiently soluble in $\mathrm{CD}_{3} \mathrm{CN}$ upon heating to allow acquisition of NMR data. Small colourless crystals appeared after 3 days sealed under $\mathrm{N}_{2}$ in J. Young's tap NMR tube. Crystal data was obtained and a ${ }^{1} \mathrm{H}$ spectrum was collected for the compound.

${ }^{1} \mathrm{H}$ NMR $\left(\mathrm{CD}_{3} \mathrm{CN}, 300 \mathrm{MHz}\right) \delta 7.50 \mathrm{ppm}$ to $6.94 \mathrm{ppm}$ (unassigned aromatic proton peaks), $4.95(\mathrm{~s}, 1 \mathrm{H}), 4.77(\mathrm{~s}, 1 \mathrm{H}), 4.57(\mathrm{~m} 1 \mathrm{H}), 3.71 \mathrm{ppm}$ to $1.88 \mathrm{ppm}$ (unassigned hpp proton peaks)

\section{Heating of $1,2-\left(\mathrm{CH}_{2} \mathrm{hpp}\right)_{2}-\mathrm{C}_{6} \mathrm{H}_{4}$ in $\mathrm{CD}_{3} \mathrm{CN}$}

An NMR sample of $1,2-\left(\mathrm{CH}_{2} \mathrm{hpp}\right)_{2}-\mathrm{C}_{6} \mathrm{H}_{4}$ was heated in $\mathrm{CD}_{3} \mathrm{CN}$ at $60^{\circ} \mathrm{C}$ for 3 days. No change in the resonances of the ligand were observed.

\section{Attempted Synthesis of $\mathrm{SbCl}_{3} \bullet 1,3-\left(\mathrm{CH}_{2} \mathrm{hpp}\right)_{2}-\mathrm{C}_{6} \mathrm{H}_{4}$}

A solution of $1,3-\left(\mathrm{CH}_{2} \mathrm{hpp}\right)_{2}-\mathrm{C}_{6} \mathrm{H}_{4}\left(22 \mathrm{mg}, 5.83 \times 10^{-5} \mathrm{~mol}\right)$ in $\mathrm{CD}_{3} \mathrm{CN}(\sim 0.3 \mathrm{~mL})$ was added to a solution of $\mathrm{SbCl}_{3}\left(13 \mathrm{mg}, 5.83 \times 10^{-5} \mathrm{~mol}\right)$ in $\mathrm{CD}_{3} \mathrm{CN}(\sim 0.3 \mathrm{~mL})$. A sticky 
precipitate formed immediately which was heated back into solution for ${ }^{1} \mathrm{H}$ NMR analysis. Crystallisation attempts were unsuccessful so no yield was obtained.

Note: NMR assignment is based on the numbering in the figure in the $1,3^{-}$ $\left(\mathrm{CH}_{2} \mathrm{hpp}\right)_{2}-\mathrm{C}_{6} \mathrm{H}_{4}$ ligand assignment in $\mathrm{CD}_{3} \mathrm{CN} .{ }^{1} \mathrm{H}$ NMR $\left(\mathrm{CD}_{3} \mathrm{CN}, 300 \mathrm{MHz}\right) \delta 7.35$ (m, 2H, H-1, H-3), 7.25 (m, 2H, H-2), 4.71 (s, 4H, 4H, H-4), 3.62 (pseudo-t, 4H, H6), 3.38 (pseudo-t, 4H, H-8), 3.33 (pseudo-t, 4H, H-9) 3.21 (pseudo-t, 4H, H-11), 2.02 (pseudo-quin, 4H, $\mathrm{H}^{-} 7$ ), 1.94 (pseudo-quin, 4H, $\mathrm{H}^{-10}$ )

\section{Experimental Detail from Chapter 4}

\section{Modified Synthesis of $\mathrm{PPh}_{2}(\mathrm{hpp}) 77$}

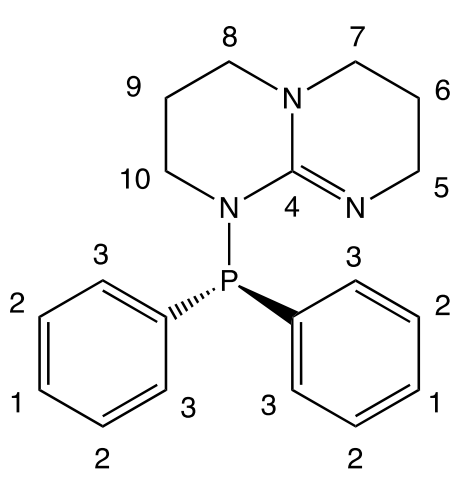

A solution of hppH $\left(0.75 \mathrm{~g}, 5.39 \times 10^{-3} \mathrm{~mol}\right)$ in THF $(\sim 40$

$\mathrm{mL})$ was added to a suspension of $95 \% \mathrm{NaH}(0.1293 \mathrm{~g}$, $\left.5.39 \times 10^{-3} \mathrm{~mol}\right)$ in THF $(\sim 20 \mathrm{~mL})$. The reaction was left stirring at room temperature overnight. $\mathrm{PPh}_{2} \mathrm{Cl}(0.998$ $\left.\mathrm{mL}, 5.56 \times 10^{-3} \mathrm{~mol}\right)$ was added with an additional approx. THF (10 mL) to help stirring. THF removed in vacuo two days later. The compound was redissolved in toluene and $\mathrm{NaCl}$ was removed by filtration. The toluene was removed in vacuo, yielding a white solid. ${ }^{1} \mathrm{H}$ NMR data collected. Yield $1.4565 \mathrm{~g}, 83.6 \%$.

${ }^{1} \mathrm{H}$ NMR $\left(\mathrm{CD}_{3} \mathrm{CN}, 300 \mathrm{MHz}\right) \delta 7.34(\mathrm{~m}, 10 \mathrm{H}, \mathrm{H}-1, \mathrm{H}-2, \mathrm{H}-3) 3.15(\mathrm{~m}, 6 \mathrm{H}, \mathrm{H}-5, \mathrm{H}-7$, $\mathrm{H}-8$ ), 2.95 (pseudo-t, 2H, H-10), 1.78 (pseudo-quin, 2H, H-6), 1.70 (pseudo-quin, $2 \mathrm{H}, \mathrm{H}-9)$ 


\section{Attempted Synthesis of $\mathrm{KN}\left\{\mathrm{SiMe}_{3}\right\}_{2} \bullet \mathrm{PPh}_{2}(\mathrm{hpp})$ and Consequent Synthesis}

of $\left[\mathrm{K}_{10}(\mathrm{hpp})_{8}\right]^{2^{+}}$

A solution of $\mathrm{PPh}_{2}(\mathrm{hpp})\left(0.100 \mathrm{~g}, 3 \times 10^{-4} \mathrm{~mol}\right)$ in toluene $(\sim 2 \mathrm{~mL})$ was added to a solution of $\mathrm{KN}\left\{\mathrm{SiMe}_{3}\right\}_{2}\left(0.0617 \mathrm{~g}, 3 \times 10^{-4} \mathrm{~mol}\right)$ in toluene $(\sim 2 \mathrm{~mL})$. Crystallisation occurred by slow evaporation of toluene. ${ }^{1} \mathrm{H}$ and ${ }^{13} \mathrm{C}$ NMR data was obtained from the crystalline material. Complete assignment of the ${ }^{1} \mathrm{H}$ NMR data could not be performed and ${ }^{13} \mathrm{C}$ NMR data was unassignable. Yield $0.0326 \mathrm{~g}$, (\% yield cannot be calculated as unidentifiable anions are present in crystal structure).

${ }^{1} \mathrm{H}$ NMR $\left(\mathrm{C}_{6} \mathrm{D}_{6}, 600 \mathrm{MHz}\right) \delta$ from $7.85 \mathrm{ppm}$ to $6.75 \mathrm{ppm}$ (unassigned aromatic peaks), from $3.42 \mathrm{ppm}$ to $1.24 \mathrm{ppm}$ (unassigned hpp proton peaks), from $0.24 \mathrm{ppm}$ to $0.10 \mathrm{ppm}$ (unassigned $\mathrm{N}\left\{\mathrm{SiMe}_{3}\right\}_{2^{-}}$peaks).

\section{Attempted Synthesis of $\left[\mathrm{K} \bullet \mathrm{PPh}_{2}(\mathrm{hpp})\right]\left[\mathrm{BPh}_{4}\right]$}

A solution of $\left[\mathrm{PPh}_{2}(\mathrm{hppH})\right]\left[\mathrm{BPh}_{4}\right]\left(0.0300 \mathrm{~g}, 9 \times 10^{-5} \mathrm{~mol}\right)$ in $\mathrm{CD}_{3} \mathrm{CN}(\sim 0.3 \mathrm{~mL})$ was added to a solution of $\mathrm{KN}\left\{\mathrm{SiMe}_{3}\right\}_{2}\left(0.0184 \mathrm{~g}, 9 \times 10^{-5} \mathrm{~mol}\right) \mathrm{CD}_{3} \mathrm{CN}(\sim 0.3 \mathrm{~mL})$. A yellow precipitate formed which could not be dissolved on heating to $70^{\circ} \mathrm{C}$. No NMR or Xray data could be obtained.

\section{Attempted Synthesis of $\mathrm{LiN}\left\{\mathrm{SiMe}_{3}\right\}_{2} \bullet \mathrm{PPh}_{2}(\mathrm{hpp})$ and Consequent Synthesis} of $\mathrm{Li}_{3}\left(\mathrm{~N}\left\{\mathrm{PPh}_{2}\right\}_{2}\right)(\mathrm{hpp})_{2}(\mathrm{THF})_{3}$

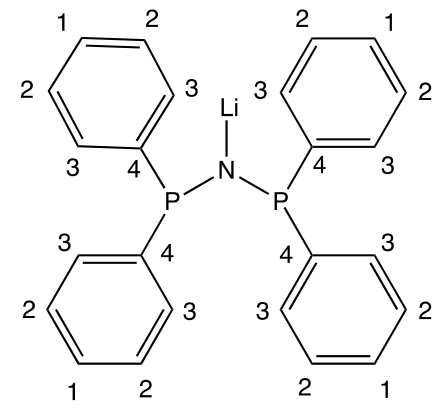

Note: Diagram is just of the $\operatorname{LiN}\left(\mathrm{PPh}_{2}\right)_{2}$ section of the compound. A solution of $\mathrm{LiN}\left\{\mathrm{SiMe}_{3}\right\}_{2}\left(0.052 \mathrm{~g}, 3 \times 10^{-4}\right.$ mol) in THF $(\sim 2 \mathrm{~mL})$ was added to a solution of $\mathrm{PPh}_{2}(\mathrm{hpp})\left(0.100 \mathrm{~g}, 3 \times 10^{-4} \mathrm{~mol}\right)$ in $\mathrm{THF}(\sim 2 \mathrm{~mL})$ and stirred overnight at room temperature. Crystallisation occurred via slow evaporation of $\mathrm{THF}$ at room temperature. ${ }^{1} \mathrm{H}$ and ${ }^{13} \mathrm{C}$ NMR data 
was obtained from the crystalline material. Complete assignment of the NMR data could not be performed and ${ }^{13} \mathrm{C}$ NMR data was unassignable. Yield $0.1248 \mathrm{~g}, 15 \%$ ${ }^{1} \mathrm{H}$ NMR $\left(\mathrm{C}_{6} \mathrm{D}_{6}, 600 \mathrm{MHz}\right) \delta 7.63\left(\mathrm{t}, \mathrm{J}_{\mathrm{HH}}=6.7 \mathrm{~Hz}, 4 \mathrm{H}, \mathrm{H}-3\right), 7.16$ (m, overlapping with solvent peak, $\mathrm{H}-2), 7.06\left(\mathrm{t}, \mathrm{J}_{\mathrm{HH}}=7.4 \mathrm{~Hz}, 2 \mathrm{H}, \mathrm{H}-1\right)$, from $3.57 \mathrm{ppm}$ to $1.41 \mathrm{ppm}$ (unassigned hpp proton peaks), $0.23\left(\mathrm{~s}, 8 \mathrm{H}, \mathrm{N}\left\{\mathrm{SiMe}_{3}\right\}_{2}^{-}\right)$

Attempted synthesis of $\mathrm{AlMe}_{3} \bullet \mathrm{PPh}_{2}(\mathrm{hpp})$ and Consequent Synthesis of $\left\{\left(\mu^{-}\right.\right.$ $\left.\mathrm{hpp})-\mathrm{AlMe}_{2}\right\}_{2}$

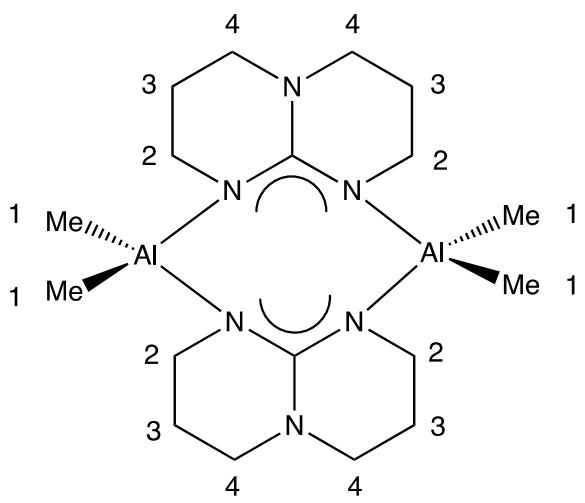

A solution of $\mathrm{AlMe}_{3}\left(0.15 \mathrm{~mL}, 2 \mathrm{molL}^{-1}\right.$ in toluene, $\left.3.09 \times 10^{-4} \mathrm{~mol}\right)$ was added dropwise to a solution of $\mathrm{PPh}_{2}(\mathrm{hpp})\left(0.1 \mathrm{~g}, 3.09 \times 10^{-4} \mathrm{~mol}\right)$ in $\mathrm{THF}$ (10mL). Large colourless block-shaped crystals formed after 3 weeks at $-30^{\circ} \mathrm{C}$. X-ray data was not fully collected as structure not novel, ${ }^{1} \mathrm{H}$ NMR and ${ }^{31} \mathrm{P}$ NMR collected from crystalline material. Yield $0.05 \mathrm{~g}, 43 \%$

${ }^{1} \mathrm{H}$ NMR $\left(\mathrm{C}_{6} \mathrm{D}_{6}, 300 \mathrm{MHz}\right) \quad \delta 7.37$ (unassigned aromatic), 7.05 (unassigned aromatic), 3.11 (pseudo-t, 8H, H-2), 2.39 (pseudo-t, 8H, H-4), 1.49 (pseudo-quin, $8 \mathrm{H}, \mathrm{H}-3),-0.33(\mathrm{~s}, 12 \mathrm{H}, \mathrm{H}-1){ }^{31} \mathrm{P}$ NMR $\left(\mathrm{C}_{6} \mathrm{D}_{6}, 120 \mathrm{MHz}\right) \delta-27.0\left(\mathrm{~s}, \mathrm{Ph}_{2} \mathrm{P}-\mathrm{PPh}_{2}\right)$ 


\section{Experimental Detail from Chapter 5}

\section{Attempted Syntheses of $\mathrm{Mn} \bullet \mathrm{Ph}\left(\mathrm{CH}_{2} \mathrm{hpp}\right)$ :}

\section{Attempted Synthesis of $\mathrm{Mn}\left(\mathrm{N}\left\{\mathrm{SiMe}_{3}\right\}_{2}\right)_{2}$ (a)}

$\mathrm{MnCl}_{2}\left(0.36 \mathrm{~g}, 2.86 \times 10^{-3} \mathrm{~mol}\right)$ was ground into a fine powder and stirred for 8 hours in toluene. $\mathrm{LiN}\left\{\mathrm{SiMe}_{3}\right\}_{2}\left(0.95 \mathrm{~g}, 5.72 \times 10^{-3} \mathrm{~mol}\right)$ was added to pink $\mathrm{MnCl}_{2}$ suspension and stirred at RT for 16 hours. A black precipitate was removed by filtration and the resultant yellow-orange solution was concentrated in vacuo. Crystallisation of $\mathrm{LiN}\left\{\mathrm{SiMe}_{3}\right\}_{2}$ starting material occurred at $-30^{\circ} \mathrm{C}$.

\section{Attempted In-situ Synthesis of $\left[\mathrm{Ph}\left(\mathrm{CH}_{2} \mathrm{hpp}\right) \bullet \mathrm{MnN}\left\{\mathrm{SiMe}_{3}\right\}_{2}\right]\left[\mathrm{BPh} \mathrm{B}_{4}\right](\mathrm{b})$}

$\mathrm{HN}\left\{\mathrm{SiMe}_{3}\right\}_{2}\left(1.28 \mathrm{~g}, 7.96 \times 10^{-3} \mathrm{~mol}\right)$ was added to $\mathrm{n}-\mathrm{BuLi}\left(4 \mathrm{~mL}, 7.96 \times 10^{-3} \mathrm{~mol}, 2 \mathrm{M}\right.$ in toluene) and stirred for 1 hour. This was followed by the addition of ground $\mathrm{MnCl}_{2}\left(0.5 \mathrm{~g}, 3.98 \times 10^{-3} \mathrm{~mol}\right)$ and stirred for 16 hours. $\left[\mathrm{Ph}\left(\mathrm{CH}_{2} \mathrm{hppH}\right)\right]\left[\mathrm{BPh}_{4}\right](2.187$ $\left.\mathrm{g}, 3.98 \times 10^{-3} \mathrm{~mol}\right)$ was added to the black precipitate formed and stirred for 16 hours. The solvent was removed in vacuo before the black solid was redissolved in hexane. The resultant black solution was filtered through celite to afford a clear pale yellow solution. Crystallisation occurred from the solution at $-30^{\circ} \mathrm{C}$ within 24 hours. Yield $0.295 \mathrm{~g}, 12 \%$

Attempted Synthesis of $\left[\mathrm{Ph}\left(\mathrm{CH}_{2} \mathrm{hpp}\right) \bullet \mathrm{MnN}\left\{\mathrm{SiMe}_{3}\right\}_{2}\right]\left[\mathrm{BPh}_{4}\right]$ (c) 
A solution of compound $25\left(0.2951 \mathrm{~g}, 4.6 \times 10^{-4} \mathrm{~mol}\right)$ in THF was added to a solution of $\left[\mathrm{Ph}\left(\mathrm{CH}_{2} \mathrm{hppH}\right)\right]\left[\mathrm{BPh}_{4}\right]\left(0.256 \mathrm{~g}, 4.6 \times 10^{-4} \mathrm{~mol}\right)$ in THF and stirred at RT for 16 hours. A small amount of insoluble fine powder precipitated out and was removed by filtration through celite. Crystallisation occurred from the resultant solution at $-30^{\circ} \mathrm{C}$ within 4 days. X-ray data showed $\left[\mathrm{Li}(\mathrm{THF})_{4}\right]\left[\mathrm{BPh}_{4}\right]$ had been synthesised. Yield $0.109 \mathrm{~g}, 48 \%$ 


\section{References}

1. W. H. Organisation, World Cancer Report 2014, 2014.

2. D. Hanahan and R. A. Weinberg, Cell (Cambridge, Mass.), 2000, 100, 57-70.

3. $\quad$ C. M. Croce, N. Engl. J. Med., 2008, 358, 502-511.

4. $\quad$ C. J. Sherr, Cell (Cambridge, MA, U. S.), 2004, 116, 235-246.

5. B. A. Chabner and T. G. Roberts, Nat. Rev. Cancer, 2005, 5, 65-72.

6. A. C. McCue, C. I. Muldoon, E.-D. Karic and T. A. Shell, 2016.

7. S. Medici, M. Peana, V. M. Nurchi, J. I. Lachowicz, G. Crisponi and M. A. Zoroddu, Coord. Chem. Rev., 2015, 284, 329-350.

8. B. Rosenberg, L. VanCamp, J. E. Trosko and V. H. Mansour, Nature, 1969, 222, 385-386.

9. E. R. Jamieson and S. J. Lippard, Chem. Rev. (Washington, D. C.), 1999, 99, 2467-2498.

10. M. Galanski, M. A. Jakupec and B. K. Keppler, Curr. Med. Chem., 2005, 12, 2075-2094.

11. D. Wang and S. J. Lippard, Nat. Rev. Drug Discovery, 2005, 4, 307320.

12. M. G. Apps, E. H. Y. Choi and N. J. Wheate, Endocr-Relat. Cancer, 2015, 22, R219-R233.

13. N. Poklar, D. S. Pilch, S. J. Lippard, E. A. Redding, S. U. Dunham and K. J. Breslauer, Proc. Natl. Acad. Sci. U. S. A., 1996, 93, 76067611.

14. M. P. Decatris, S. Sundar and K. J. O'Byrne, Cancer Treat. Rev., 2004, 30, 53-81.

15. E. Wong and C. M. Giandomenico, Chem. Rev. (Washington, D. C.), 1999, 99, 2451-2466.

16. L. Galluzzi, L. Senovilla, I. Vitale, J. Michels, I. Martins, O. Kepp, M. Castedo and G. Kroemer, Oncogene, 2012, 31, 1869-1883.

17. J. Reedijk, Platinum Met. Rev., 2008, 52, 2-11.

18. G. Suess-Fink, Dalton Trans., 2010, 39, 1673-1688.

19. P. C. A. Bruijnincx and P. J. Sadler, Adv. Inorg. Chem., 2009, 61, 162.

20. A. F. A. Peacock and P. J. Sadler, Chem. - Asian J., 2008, 3, 18901899.

21. A. F. A. Peacock, A. Habtemariam, R. Fernandez, V. Walland, F. P. A. Fabbiani, S. Parsons, R. E. Aird, D. I. Jodrell and P. J. Sadler, J. Am. Chem. Soc., 2006, 128, 1739-1748.

22. G. Sava, S. Pacor, F. Bregant and V. Ceschia, Anticancer Res., 1991, 11, 1103-1107.

23. E. Musgrove, C. Rugg, I. Taylor and D. Hedley, J. Cell. Physiol., 1984, 118, 6-12. 
24. C. G. Hartinger, S. Zorbas-Seifried, M. A. Jakupec, B. Kynast, H. Zorbas and B. K. Keppler, J. Inorg. Biochem., 2006, 100, 891-904.

25. L. Messori, F. G. Vilchez, R. Vilaplana, F. Piccioli, E. Alessio and B. Keppler, Met.-Based Drugs, 2000, 7, 335-342.

26. M. Pongratz, P. Schluga, M. A. Jakupec, V. B. Arion, C. G. Hartinger, G. Allmaier and B. K. Keppler, J. Anal. At. Spectrom., 2004, 19, 4651.

27. F. Kratz, M. Hartmann, B. Keppler and L. Messori, J. Biol. Chem., 1994, 269, 2581-2588.

28. E. S. Antonarakis and A. Emadi, Cancer Chemother. Pharmacol., 2010, 66, 1-9.

29. C. S. Allardyce, A. Dorcier, C. Scolaro and P. J. Dyson, Appl. Organomet. Chem., 2005, 19, 1-10.

30. V. Brabec, Prog. Nucleic Acid Res. Mol. Biol., 2002, 71, 1-68.

31. A. Vacca, M. Bruno, A. Boccarelli, M. Coluccia, D. Ribatti, A. Bergamo, S. Garbisa, L. Sartor and G. Sava, Br. J. Cancer, 2002, 86, 993-998.

32. G. Sava, S. Zorzet, C. Turrin, F. Vita, M. Soranzo, G. Zabucchi, M. Cocchietto, A. Bergamo, S. DiGiovine, G. Pezzoni, L. Sartor and S. Garbisa, Clin. Cancer Res., 2003, 9, 1898-1905.

33. S. Kapitza, M. Pongratz, M. A. Jakupec, P. Heffeter, W. Berger, L. Lackinger, B. K. Keppler and B. Marian, J. Cancer Res. Clin. Oncol., 2005, 131, 101-110.

34. S. Kapitza, M. A. Jakupec, M. Uhl, B. K. Keppler and B. Marian, Cancer Lett. (Amsterdam, Neth.), 2005, 226, 115-121.

35. J. C. Wang, Nat. Rev. Mol. Cell Biol., 2002, 3, 430-440.

36. Y. N. V. Gopal, D. Jayaraju and A. K. Kondapi, Biochemistry, 1999, 38, 4382-4388.

37. A. Bergamo and G. Sava, Dalton Trans., 2011, 40, 7817-7823.

38. R. A. Gatenby and R. J. Gillies, Nat. Rev. Cancer, 2004, 4, 891-899.

39. E. Alessio, G. Mestroni, A. Bergamo and G. Sava, Met. Ions Biol. Syst., 2004, 42, 323-351.

40. G. Sava, A. Bergamo, S. Zorzet, B. Gava, C. Casarsa, M. Cocchietto, A. Furlani, V. Scarcia, B. Serli, E. Iengo, E. Alessio and G. Mestroni, Eur. J. Cancer, 2002, 38, 427-435.

41. A. Bergamo, C. Gaiddon, J. H. M. Schellens, J. H. Beijnen and G. Sava, J. Inorg. Biochem., 2012, 106, 90-99.

42. G. Jaouen and A. Vessieres, Pure Appl. Chem., 1985, 57, 1865-1874.

43. W.-H. Ang, A. Casini, G. Sava and P. J. Dyson, J. Organomet. Chem., 2011, 696, 989-998.

44. P. Kopf-Maier, Anticancer Res., 1999, 19, 493-504.

45. A. Habtemariam, M. Melchart, R. Fernandez, S. Parsons, I. D. H. Oswald, A. Parkin, F. P. A. Fabbiani, J. E. Davidson, A. Dawson, R. E. Aird, D. I. Jodrell and P. J. Sadler, J. Med. Chem., 2006, 49, 68586868.

46. S. Korn and W. S. Sheldrick, J. Chem. Soc., Dalton Trans., 1997, 2191-2199. 
47. M. Melchart, A. Habtemariam, O. Novakova, S. A. Moggach, F. P. A. Fabbiani, S. Parsons, V. Brabec and P. J. Sadler, Inorg. Chem., 2007, 46, 8950-8962.

48. G. S. Smith and B. Therrien, Dalton Trans., 2011, 40, 10793-10800.

49. H. Chen, J. A. Parkinson, S. Parsons, R. A. Coxall, R. O. Gould and P. J. Sadler, J. Am. Chem. Soc., 2002, 124, 3064-3082.

50. R. E. Morris, R. E. Aird, P. d. S. Murdoch, H. Chen, J. Cummings, N. D. Hughes, S. Parsons, A. Parkin, G. Boyd, D. I. Jodrell and P. J. Sadler, J. Med. Chem., 2001, 44, 3616-3621.

51. Y. K. Yan, M. Melchart, A. Habtemariam and P. J. Sadler, Chem. Commun. (Cambridge, U. K.), 2005, 4764-4776.

52. H. Chen, J. A. Parkinson, R. E. Morris and P. J. Sadler, J. Am. Chem. Soc., 2003, 125, 173-186.

53. L. He, S.-Y. Liao, C.-P. Tan, R.-R. Ye, Y.-W. Xu, M. Zhao, L.-N. Ji and Z.-W. Mao, Chem. - Eur. J., 2013, 19, 12152-12160.

54. J. Bravo, S. Bolano, L. Gonsalvi and M. Peruzzini, Coord. Chem. Rev., 2010, 254, 555-607.

55. Y. Q. Tan, P. J. Dyson and W. H. Ang, Organometallics, 2011, 30, 5965-5971.

56. B. Wu, M. S. Ong, M. Groessl, Z. Adhireksan, C. G. Hartinger, P. J. Dyson and C. A. Davey, Chem. - Eur. J., 2011, 17, 3562-3566.

57. C. Scolaro, A. Bergamo, L. Brescacin, R. Delfino, M. Cocchietto, G. Laurenczy, T. J. Geldbach, G. Sava and P. J. Dyson, J. Med. Chem., 2005, 48, 4161-4171.

58. C. S. Allardyce, P. J. Dyson, D. J. Ellis, P. A. Salter and R. Scopelliti, J. Organomet. Chem., 2003, 668, 35-42.

59. R. Mitra, S. Das, S. V. Shinde, S. Sinha, K. Somasundaram and A. G. Samuelson, Chem. - Eur. J., 2012, 18, 12278-12291, S12278/12271S12278/12219.

60. B. Therrien, T. R. Ward, M. Pilkington, C. Hoffmann, F. Gilardoni and J. Weber, Organometallics, 1998, 17, 330-337.

61. Y. Miyaki, T. Onishi and H. Kurosawa, Inorg. Chim. Acta, 2000, 300302, 369-377.

62. M. P. Coles, Chem. Commun. (Cambridge, U. K.), 2009, 3659-3676.

63. M. P. Coles, Dalton Trans., 2006, 985-1001.

64. B. Laramee-Milette and G. S. Hanan, Dalton Trans., 2016, 45, 1250712517.

65. G. Bomann, Masters, Victoria University of Wellington, 2017.

66. C. Knapp, E. Lork, T. Borrmann, W.-D. Stohrer and R. Mews, Z. Anorg. Allg. Chem., 2005, 631, 1885-1892.

67. A. G. Avent, F. Antolini, P. B. Hitchcock, A. V. Khvostov, M. F. Lappert and A. V. Protchenko, Dalton Trans., 2006, 919-927.

68. R. D. Shannon, Acta Crystallogr., Sect. A, 1976, A32, 751-767.

69. I. Caracelli, I. Haiduc, J. Zukerman-Schpector and E. R. T. Tiekink, Coord. Chem. Rev., 2013, 257, 2863-2879.

70. U. Monkowius and M. Ertl, J. Mol. Struct., 2013, 1033, 280-283. 
71. A. Islam, J. G. Da Silva, F. M. Berbet, S. M. da Silva, B. L. Rodrigues, H. Beraldo, M. N. Melo, F. Frezard and C. Demicheli, Molecules, 2014, 19, 6009-6030, 6022 pp.

72. S. Solyntjes, J. Bader, B. Neumann, H.-G. Stammler, N. Ignat'ev and B. Hoge, Chem. - Eur. J., 2017, 23, 1557-1567.

73. M. P. Coles, M. S. Khalaf and P. B. Hitchcock, Inorg. Chim. Acta, 2014, 422, 228-234.

74. G. H. Aylward and T. J. V. Findlay, SI Chemical Data. 2nd Ed, Wiley, 1974.

75. M. Bujak, Acta Crystallogr., Sect. C: Cryst. Struct. Commun., 2010, 66, m101-m103.

76. B. M. Day, M. P. Coles and P. B. Hitchcock, Eur. J. Inorg. Chem., 2012, 2012, 841-846.

77. P. W. Dyer, J. Fawcett and M. J. Hanton, Organometallics, 2008, 27, 5082-5087.

78. S. R. Boss, M. P. Coles, R. Haigh, P. B. Hitchcock, R. Snaith and A. E. H. Wheatley, Angew. Chem., Int. Ed., 2003, 42, 5593-5596.

79. S. H. Oakley, M. P. Coles and P. B. Hitchcock, Inorg. Chem., 2004, 43, 5168-5172.

80. T. Kremer, F. Hampel, F. A. Knoch, W. Bauer, A. Schmidt, P. Gabold, M. Schuetz, J. Ellermann and P. v. R. Schleyer, Organometallics, 1996, 15, 4776-4782.

81. B. L. Lucht and D. B. Collum, J. Am. Chem. Soc., 1995, 117, 98639874.

82. S. L. Aeilts, M. P. Coles, D. C. Swenson, R. F. Jordan and V. G. Young, Jr., Organometallics, 1998, 17, 3265-3270.

83. U. Siemeling, U. Vorfeld, B. Neumann and H.-G. Stammler, Inorg. Chem., 2000, 39, 5159-5160.

84. L. Kaufmann and M. Bolte, CCDC 794620: Experimental Crystal Structure Determination, CCDC, 2014. 


\section{Appendix One - Crystallographic Data}

\section{Compound 4}

Table 1 Crystal data and structure refinement for cal2_29.

Identification code

cal2_29

Empirical formula

$\mathrm{C}_{40} \mathrm{H}_{74} \mathrm{~N}_{8} \mathrm{Na}_{2} \mathrm{Si}_{4}$

Formula weight

825.41

Temperature/K

173.15

Crystal system

triclinic

Space group

P-1

$\mathrm{a} / \AA$

$8.8739(2)$

$\mathrm{b} / \AA$

$13.7362(3)$

$\mathrm{c} / \AA$

$20.5485(4)$

$\alpha /{ }^{\circ}$

$74.529(2)$

$\beta /{ }^{\circ}$

$84.117(2)$

$\gamma /{ }^{\circ}$

83.491(2)

Volume/ $\AA^{3}$

2391.58(10)

Z

2

$\rho_{\text {calc }} / \mathrm{cm}^{3}$

1.146

$\mu / \mathrm{mm}^{-1}$

1.605

$\mathrm{F}(000)$

896.0

Crystal size $/ \mathrm{mm}^{3}$

$0.24 \times 0.16 \times 0.15$

Radiation

$\mathrm{Cu} \mathrm{K \alpha}(\lambda=1.54184)$

$2 \Theta$ range for data collection $/{ }^{\circ} 6.7038$ to 136.5016

Index ranges

$-10 \leq \mathrm{h} \leq 10,-16 \leq \mathrm{k} \leq 16,-24 \leq 1 \leq 24$

Reflections collected 30269

Independent reflections

$8769\left[\mathrm{R}_{\text {int }}=0.0277, \mathrm{R}_{\text {sigma }}=0.039\right]$

Data/restraints/parameters

$8769 / 0 / 509$

Goodness-of-fit on $\mathrm{F}^{2}$

1.012

Final $R$ indexes $[\mathrm{I}>=2 \sigma(\mathrm{I})] \quad \mathrm{R}_{1}=0.032, \mathrm{wR}_{2}=0.082$

Final $\mathrm{R}$ indexes [all data] $\quad \mathrm{R}_{1}=0.035, \mathrm{wR}_{2}=0.084$

Largest diff. peak/hole / e $\AA^{-3} 0.30 /-0.40$

One of the methylene groups is disordered and was modelled over two positions.

\section{DATA SOLVED BY DR MARTYN COLES}

Data collection SuperNova, Dual, Cu at zero, EOS , Program package WinGX, Abs. correction 'MULTISCAN' Refinement using SHELXL-2013 


\section{Compound 11}

Table 1 Crystal data and structure refinement for cal1_59a.

Identification code

cal1_59a

Empirical formula

$\mathrm{C}_{34} \mathrm{H}_{56} \mathrm{~N}_{7} \mathrm{Si}_{2} \mathrm{~K}$

Formula weight

658.13

Temperature/K

173.15

Crystal system

triclinic

Space group

P-1

$\mathrm{a} / \AA$

$10.0790(4)$

$\mathrm{b} / \AA$

$12.5340(8)$

c/A

15.9759(6)

$\alpha /{ }^{\circ}$

71.927(4)

$\beta /{ }^{\circ}$

87.924(3)

$\gamma /{ }^{\circ}$

$77.190(4)$

Volume $/ \AA^{3}$

1869.76(16)

$\mathrm{Z}$

2

$\rho_{\text {calc }} \mathrm{g} / \mathrm{cm}^{3}$

1.169

$\mu / \mathrm{mm}^{-1}$

2.093

$\mathrm{F}(000)$

800.0

Crystal size $/ \mathrm{mm}^{3}$

$0.20 \times 0.18 \times 0.05$

Radiation

$\mathrm{Cu} \mathrm{K \alpha}(\lambda=1.54184)$

$2 \Theta$ range for data collection/ ${ }^{\circ} 7.6084$ to 147.2394

Index ranges

$-11 \leq \mathrm{h} \leq 12,-15 \leq \mathrm{k} \leq 15,-19 \leq 1 \leq 19$

Reflections collected

22245

Independent reflections

$7483\left[\mathrm{R}_{\text {int }}=0.0455, \mathrm{R}_{\text {sigma }}=0.0518\right]$

Data/restraints/parameters

$7483 / 0 / 413$

Goodness-of-fit on $\mathrm{F}^{2}$

1.031

Final $R$ indexes $[\mathrm{I}>=2 \sigma(\mathrm{I})] \quad \mathrm{R}_{1}=0.038, \mathrm{wR}_{2}=0.098$

Final R indexes [all data] $\quad \mathrm{R}_{1}=0.043, \mathrm{wR}_{2}=0.101$

Largest diff. peak/hole / e $\AA^{-3} 0.49 /-0.56$

The structure contains a molecule of benzene solvate. One of the methylene groups is disordered and was modelled over two positions.

\section{DATA SOLVED BY DR MARTYN COLES}

Data collection SuperNova, Dual, Cu at zero, EOS , Program package WinGX, Abs. correction 'MULTISCAN' Refinement using SHELXL-2013 


\section{Compound 12}

Table 1 Crystal data and structure refinement for cal1_60a.

Identification code cal1_60a

Empirical formula

$\mathrm{C}_{17} \mathrm{H}_{34} \mathrm{~N}_{4} \mathrm{Si}_{2} \mathrm{~K}$

Formula weight 389.76

Temperature/K

173.15

Crystal system orthorhombic

Space group $\mathrm{C} 222_{1}$

$\mathrm{a} / \AA$ 9.07845(19)

$\mathrm{b} / \AA$ $21.8866(4)$

c/Å $22.3850(4)$

$\alpha /{ }^{\circ}$ 90

$\beta /{ }^{\circ}$

90

$\gamma /{ }^{\circ}$ 90

Volume $/ \AA^{3}$ 4447.81(16)

$\mathrm{Z}$ 8

$\rho_{\text {calc }} \mathrm{g} / \mathrm{cm}^{3}$

1.164

$\mu / \mathrm{mm}^{-1}$

3.163

$\mathrm{F}(000)$

1688.0

Crystal size $/ \mathrm{mm}^{3}$

$0.35 \times 0.09 \times 0.07$

Radiation

$\mathrm{Cu} \mathrm{K \alpha}(\lambda=1.54184)$

$2 \Theta$ range for data collection/ ${ }^{\circ} 7.8992$ to 145.7606

Index ranges $-11 \leq \mathrm{h} \leq 11,-27 \leq \mathrm{k} \leq 24,-27 \leq 1 \leq 27$

Reflections collected 23260

Independent reflections $4450\left[\mathrm{R}_{\text {int }}=0.0657, \mathrm{R}_{\text {sigma }}=0.0611\right]$

Data/restraints/parameters $4450 / 0 / 224$

Goodness-of-fit on $\mathrm{F}^{2}$ 1.121

Final $R$ indexes $[\mathrm{I}>=2 \sigma(\mathrm{I})] \quad \mathrm{R}_{1}=0.036, \mathrm{wR}_{2}=0.094$

Final $\mathrm{R}$ indexes [all data] $\quad \mathrm{R}_{1}=0.037, \mathrm{wR}_{2}=0.095$

Largest diff. peak/hole / e $\AA^{-3} 0.55 /-0.30$

\section{DATA SOLVED BY DR MARTYN COLES}

Data collection SuperNova, Dual, Cu at zero, EOS , Program package WinGX, Abs. correction 'MULTISCAN' Refinement using SHELXL-2013 


\section{Compound 16}

Table 1 Crystal data and structure refinement for cal1_72a.

Identification code

cal1_72a

Empirical formula

$\mathrm{C}_{22} \mathrm{H}_{32} \mathrm{~N}_{6} \mathrm{Cl}_{3} \mathrm{Sb}$

Formula weight

608.63

Temperature/K

173.15

Crystal system

orthorhombic

Space group

$\mathrm{P} 2{ }_{1} 2_{1} 2_{1}$

$\mathrm{a} / \AA$

12.1288(3)

$\mathrm{b} / \AA$

12.9176(3)

c/Å

15.6856(4)

$\alpha /{ }^{\circ}$

90

$\beta /{ }^{\circ}$

90

$\gamma /{ }^{\circ}$

90

Volume $/ \AA^{3}$

2457.54(11)

Z

4

$\rho_{\text {calc }} \mathrm{g} / \mathrm{cm}^{3}$

1.645

$\mu / \mathrm{mm}^{-1}$

12.081

$\mathrm{F}(000)$

1232.0

Crystal size $/ \mathrm{mm}^{3}$

$0.19 \times 0.15 \times 0.11$

Radiation

$\mathrm{Cu} \mathrm{K \alpha}(\lambda=1.54184)$

$2 \Theta$ range for data collection $/{ }^{\circ} 6.8428$ to 147.8326

Index ranges

$-15 \leq \mathrm{h} \leq 15,-15 \leq \mathrm{k} \leq 16,-19 \leq 1 \leq 19$

Reflections collected

9803

Independent reflections

$4695\left[R_{\text {int }}=0.0596, R_{\text {sigma }}=0.0495\right]$

Data/restraints/parameters

$4695 / 0 / 293$

Goodness-of-fit on $\mathrm{F}^{2}$

1.053

Final $R$ indexes $[\mathrm{I}>=2 \sigma(\mathrm{I})] \quad \mathrm{R}_{1}=0.027, \mathrm{wR}_{2}=0.066$

Final $\mathrm{R}$ indexes [all data] $\quad \mathrm{R}_{1}=0.028, \mathrm{wR}_{2}=0.066$

Largest diff. peak/hole / e $\AA^{-3} 0.84 /-0.90$

\section{DATA SOLVED BY DR MARTYN COLES}

Data collection SuperNova, Dual, $\mathrm{Cu}$ at zero, EOS, Program package WinGX, Abs. correction 'MULTISCAN' Refinement using SHELXL-2013 


\section{Compound 22}

Table 1 Crystal data and structure refinement for cal-ma.

\begin{tabular}{|c|c|}
\hline Identification code & cal-ma \\
\hline Empirical formula & $\mathrm{C}_{50} \mathrm{H}_{68} \mathrm{Li}_{3} \mathrm{~N}_{7} \mathrm{O}_{3} \mathrm{P}_{2}$ \\
\hline Formula weight & 897.87 \\
\hline Temperature/K & 173.15 \\
\hline Crystal system & monoclinic \\
\hline Space group & $\mathrm{P} 2{ }_{1} / \mathrm{c}$ \\
\hline $\mathrm{a} / \AA$ & $11.9852(2)$ \\
\hline $\mathrm{b} / \AA$ & $16.6049(3)$ \\
\hline $\mathrm{c} / \AA$ & $24.8466(4)$ \\
\hline$\alpha^{/ \circ}$ & 90 \\
\hline$\beta /{ }^{\circ}$ & $96.3530(16)$ \\
\hline$\gamma /{ }^{\circ}$ & 90 \\
\hline Volume $/ \AA^{3}$ & $4914.45(16)$ \\
\hline $\mathrm{Z}$ & 4 \\
\hline$\rho_{\text {calc }} \mathrm{g} / \mathrm{cm}^{3}$ & 1.214 \\
\hline$\mu / \mathrm{mm}^{-1}$ & 1.174 \\
\hline $\mathrm{F}(000)$ & 1920.0 \\
\hline Crystal size $/ \mathrm{mm}^{3}$ & $0.58 \times 0.36 \times 0.33$ \\
\hline Radiation & $\mathrm{Cu} \mathrm{K} \alpha(\lambda=1.54184)$ \\
\hline \multicolumn{2}{|c|}{$2 \Theta$ range for data collection $/{ }^{\circ} 7.1596$ to 136.502} \\
\hline Index ranges & $-14 \leq \mathrm{h} \leq 14,-18 \leq \mathrm{k} \leq 19,-29 \leq 1 \leq 29$ \\
\hline Reflections collected & 38889 \\
\hline Independent reflections & $8980\left[\mathrm{R}_{\text {int }}=0.0246, \mathrm{R}_{\text {sigma }}=0.0327\right]$ \\
\hline Data/restraints/parameters & $8980 / 96 / 759$ \\
\hline Goodness-of-fit on $\mathrm{F}^{2}$ & 1.046 \\
\hline Final $R$ indexes $[\mathrm{I}>=2 \sigma(\mathrm{I})]$ & $\mathrm{R}_{1}=0.051, \mathrm{wR}_{2}=0.135$ \\
\hline Final $\mathrm{R}$ indexes [all data] & $\mathrm{R}_{1}=0.053, \mathrm{wR}_{2}=0.137$ \\
\hline Largest diff. peak/hole / e $\AA^{-3}$ & $0.50 /-0.46$ \\
\hline
\end{tabular}

There is significant disorder in the molecule. Two of the phenyl groups, two methylene groups from a hpp-anion and several of the THF methylene groups are disordered and each were modelled over two positions.

\section{DATA SOLVED BY DR MARTYN COLES}

Data collection SuperNova, Dual, Cu at zero, EOS , Program package WinGX, Abs. correction 'MULTISCAN' Refinement using SHELXL-2013 


\section{Compound 25}

Table 1 Crystal data and structure refinement for cal1_38a.

Identification code

cal1_38a

Empirical formula

$\mathrm{C}_{24} \mathrm{H}_{60} \mathrm{LiN}_{2} \mathrm{O}_{3} \mathrm{Si}_{4} \mathrm{ClMn}$

Formula weight

634.43

Temperature/K

173.15

Crystal system

triclinic

Space group

$\mathrm{P}-1$

$\mathrm{a} / \AA$

$12.0086(4)$

$\mathrm{b} / \AA$

$12.4865(4)$

c/Å

$14.2318(4)$

$\alpha /{ }^{\circ}$

94.671(3)

$\beta /{ }^{\circ}$

93.447(3)

$\gamma /{ }^{\circ}$

118.059(3)

Volume $/ \AA^{3}$

1865.13(11)

$\mathrm{Z}$

2

$\rho_{\text {calc }} \mathrm{g} / \mathrm{cm}^{3}$

1.13

$\mu / \mathrm{mm}^{-1}$

4.952

$\mathrm{F}(000)$

686.0

Crystal size $/ \mathrm{mm}^{3}$

$0.34 \times 0.23 \times 0.14$

Radiation

$\mathrm{Cu} \mathrm{K \alpha}(\lambda=1.54184)$

$2 \Theta$ range for data collection $/{ }^{\circ} 8.0868$ to 147.0308

Index ranges

$-14 \leq \mathrm{h} \leq 14,-15 \leq \mathrm{k} \leq 15,-17 \leq 1 \leq 17$

Reflections collected 21860

Independent reflections

$7486\left[\mathrm{R}_{\text {int }}=0.0364, \mathrm{R}_{\text {sigma }}=0.0524\right]$

Data/restraints/parameters

$7486 / 0 / 337$

Goodness-of-fit on $\mathrm{F}^{2}$

1.120

Final $R$ indexes $[\mathrm{I}>=2 \sigma(\mathrm{I})] \quad \mathrm{R}_{1}=0.059, \mathrm{wR}_{2}=0.162$

Final $\mathrm{R}$ indexes [all data] $\quad \mathrm{R}_{1}=0.064, \mathrm{wR}_{2}=0.164$

Largest diff. peak/hole / e $\AA^{-3} 1.07 /-0.58$

\section{DATA SOLVED BY DR MARTYN COLES}

Data collection SuperNova, Dual, Cu at zero, EOS , Program package WinGX, Abs. correction 'MULTISCAN' Refinement using SHELXL-2013 


\section{Appendix Two $-{ }^{1} \mathrm{H}$ NMR Data of Notable \\ Compounds}

Compound 2

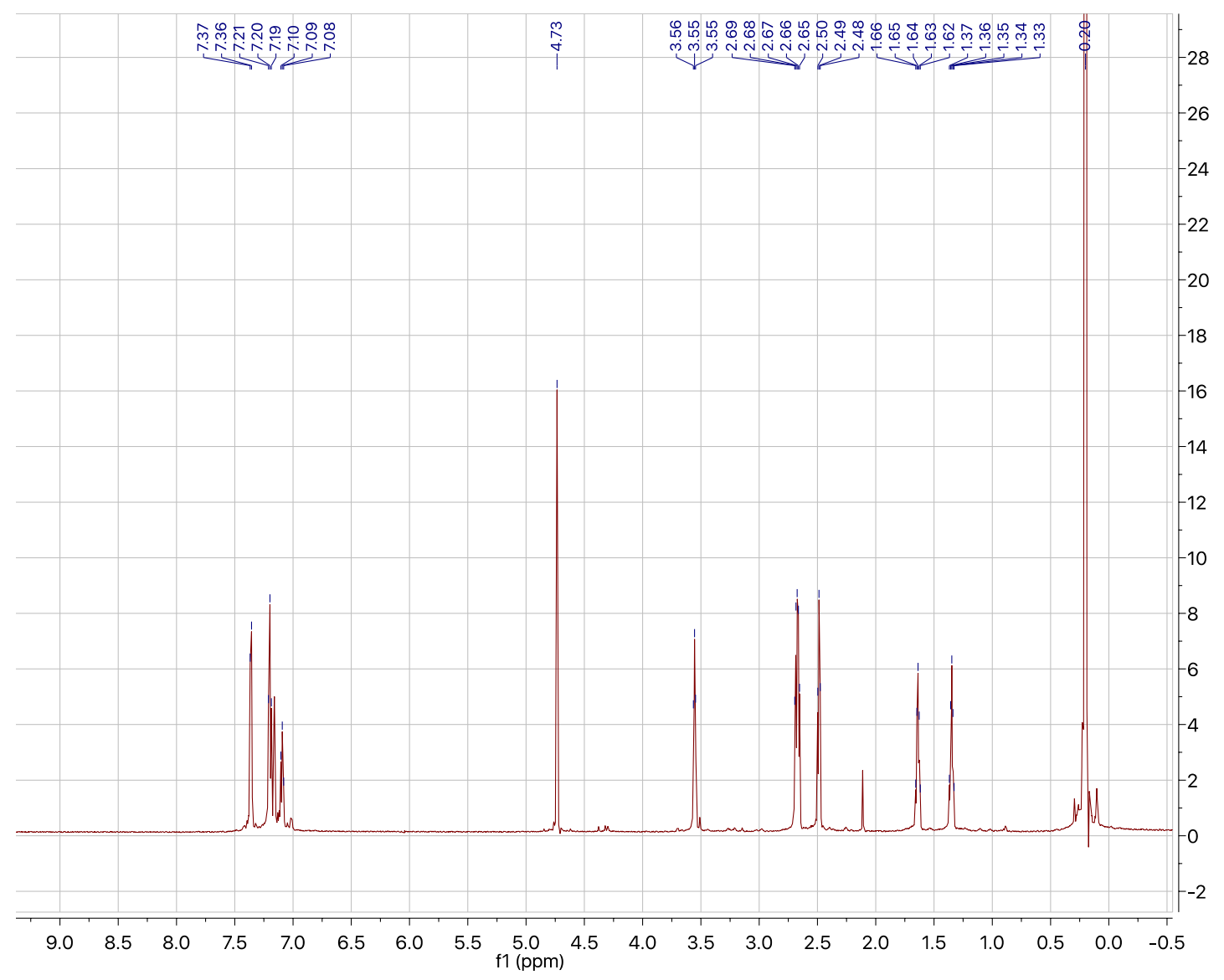




\section{Compound 3}

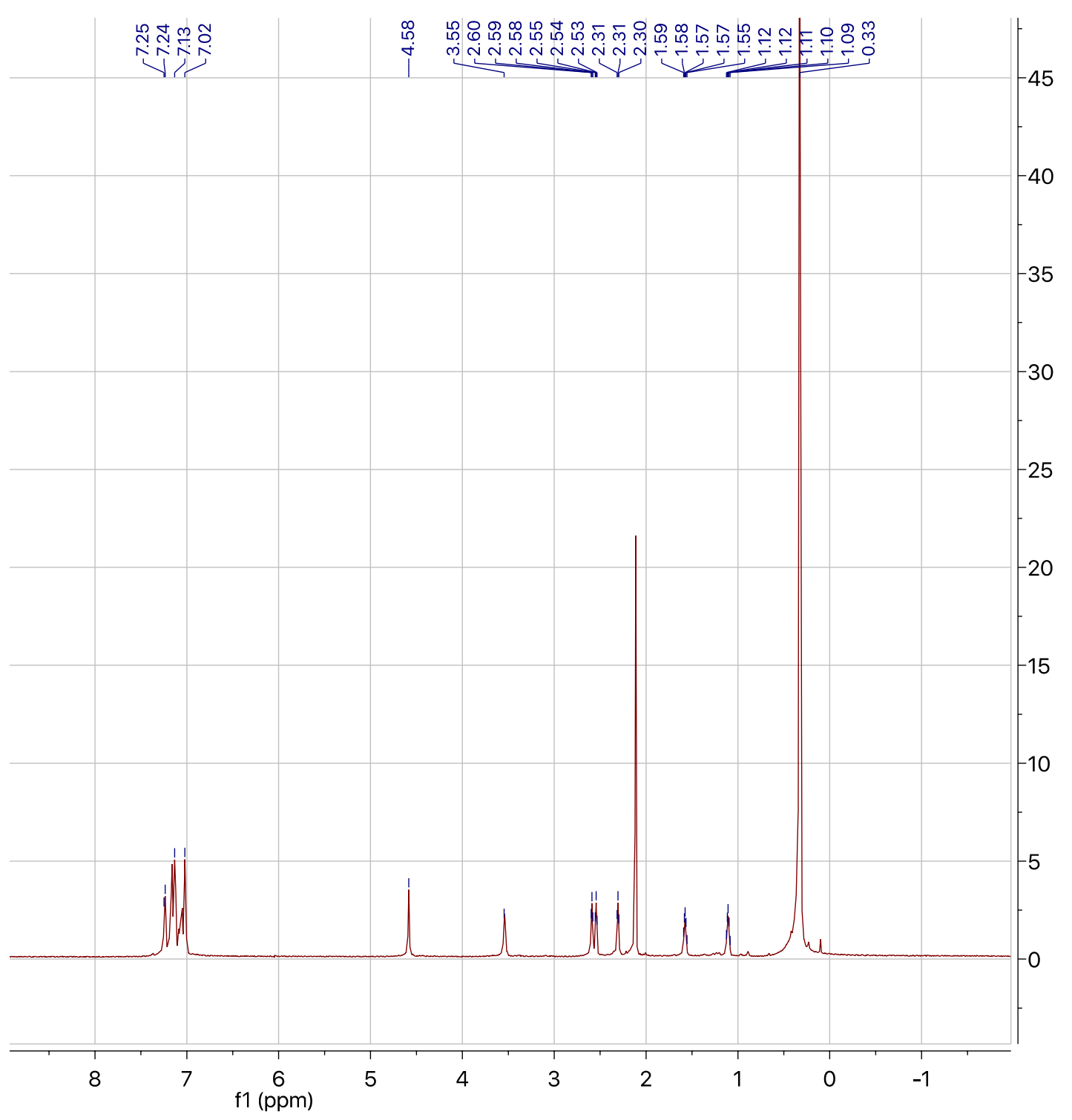




\section{Compound 4}

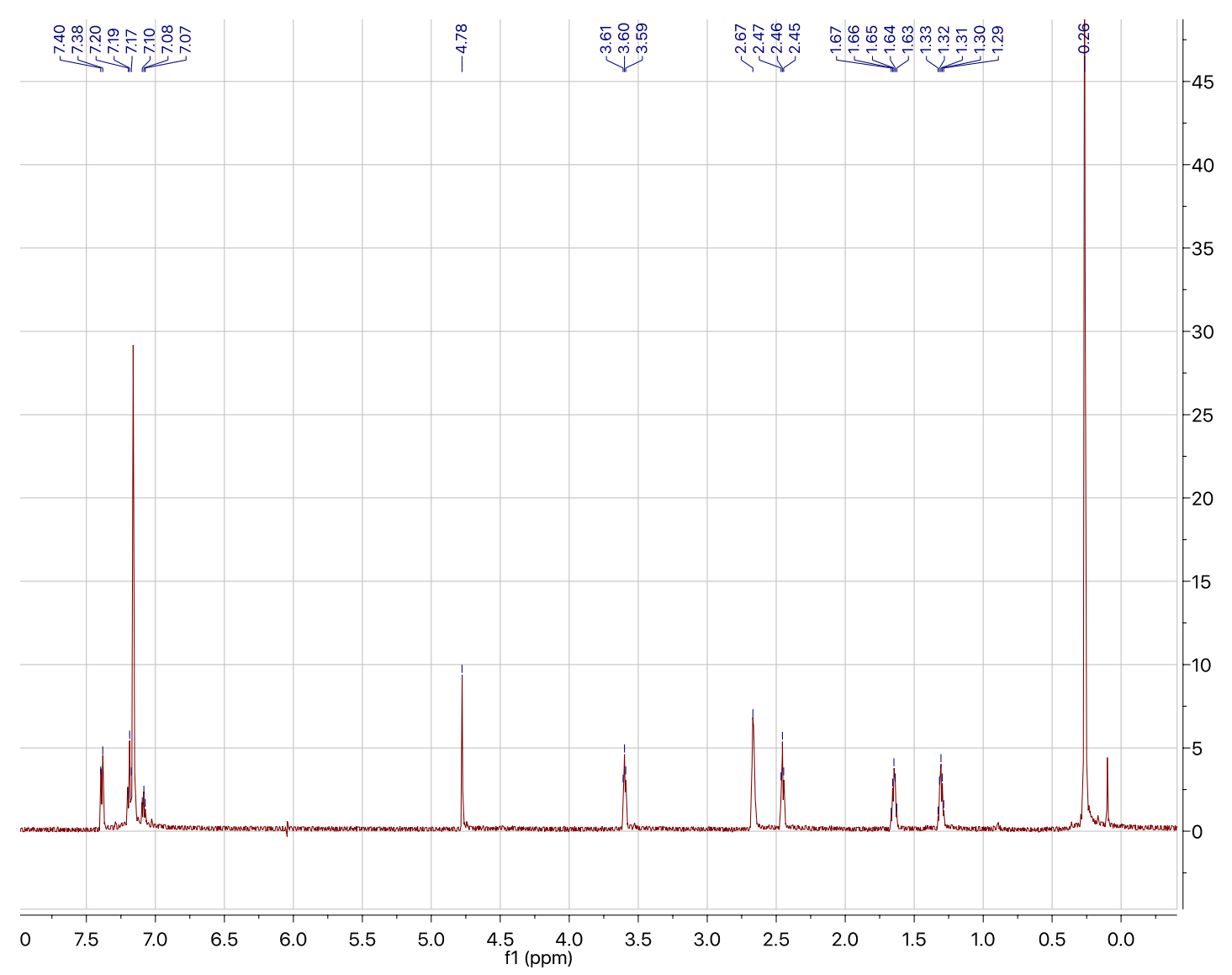




\section{Compound 9}

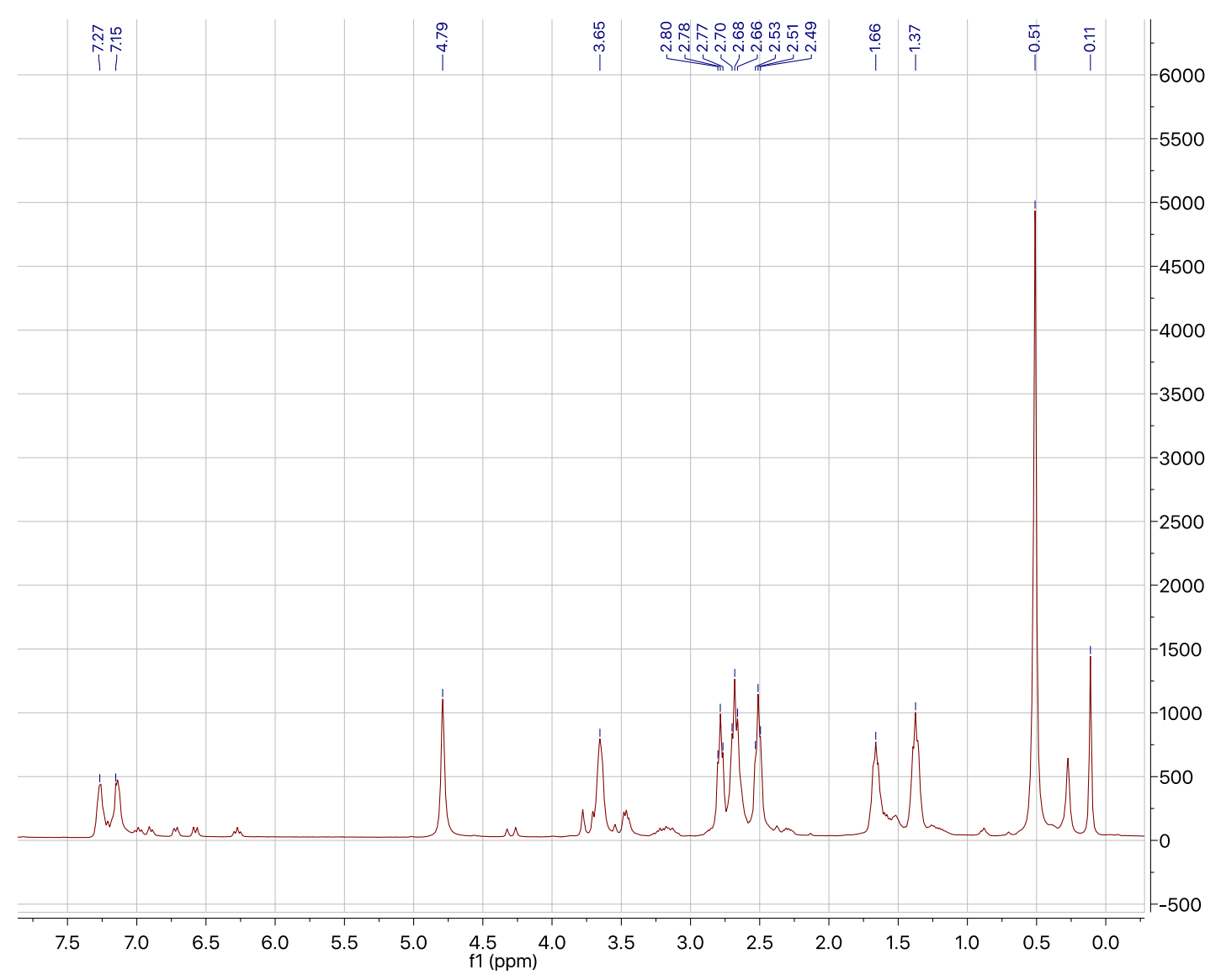




\section{Compound 10}

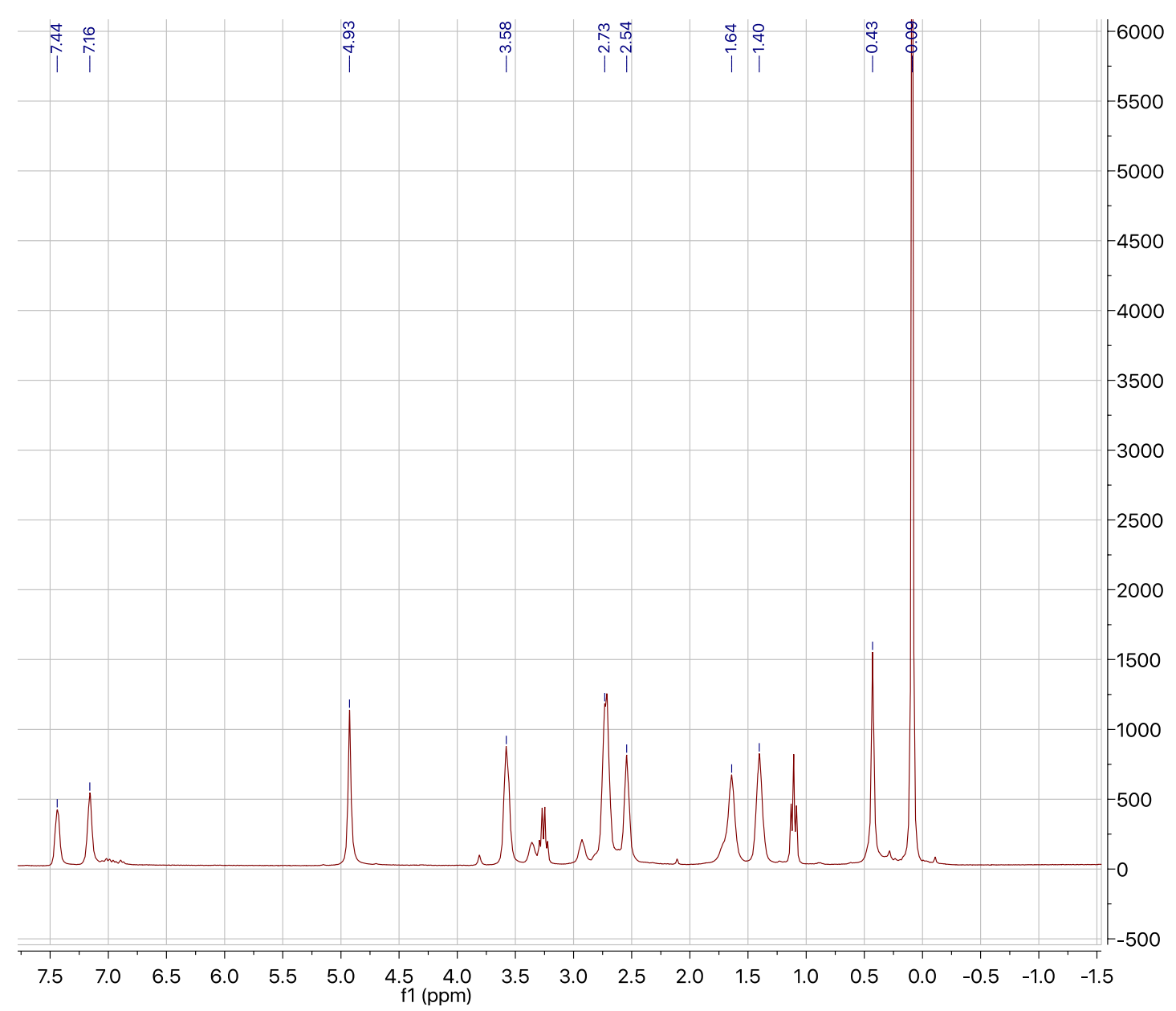




\section{Compound 11}

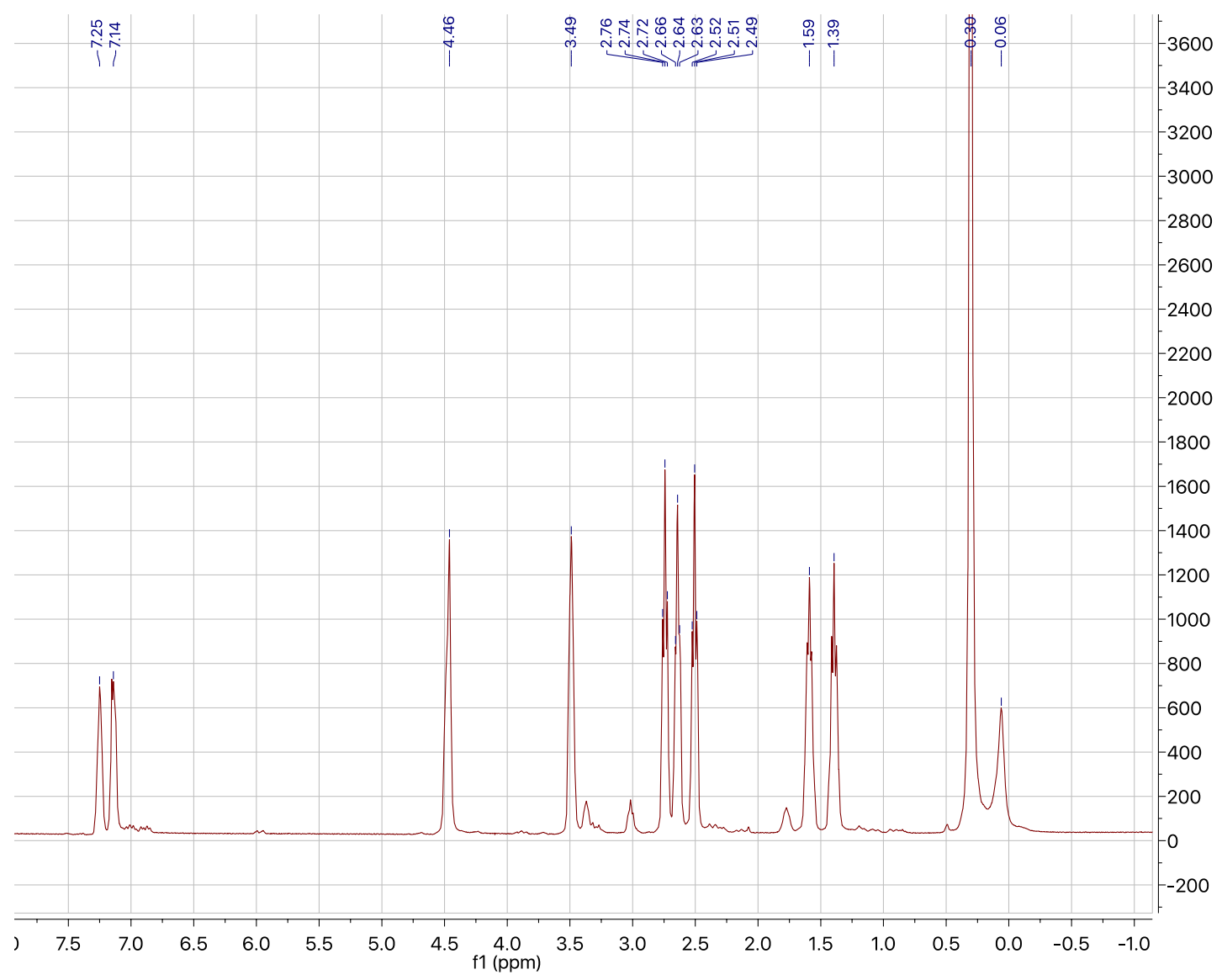




\section{Compound 12}

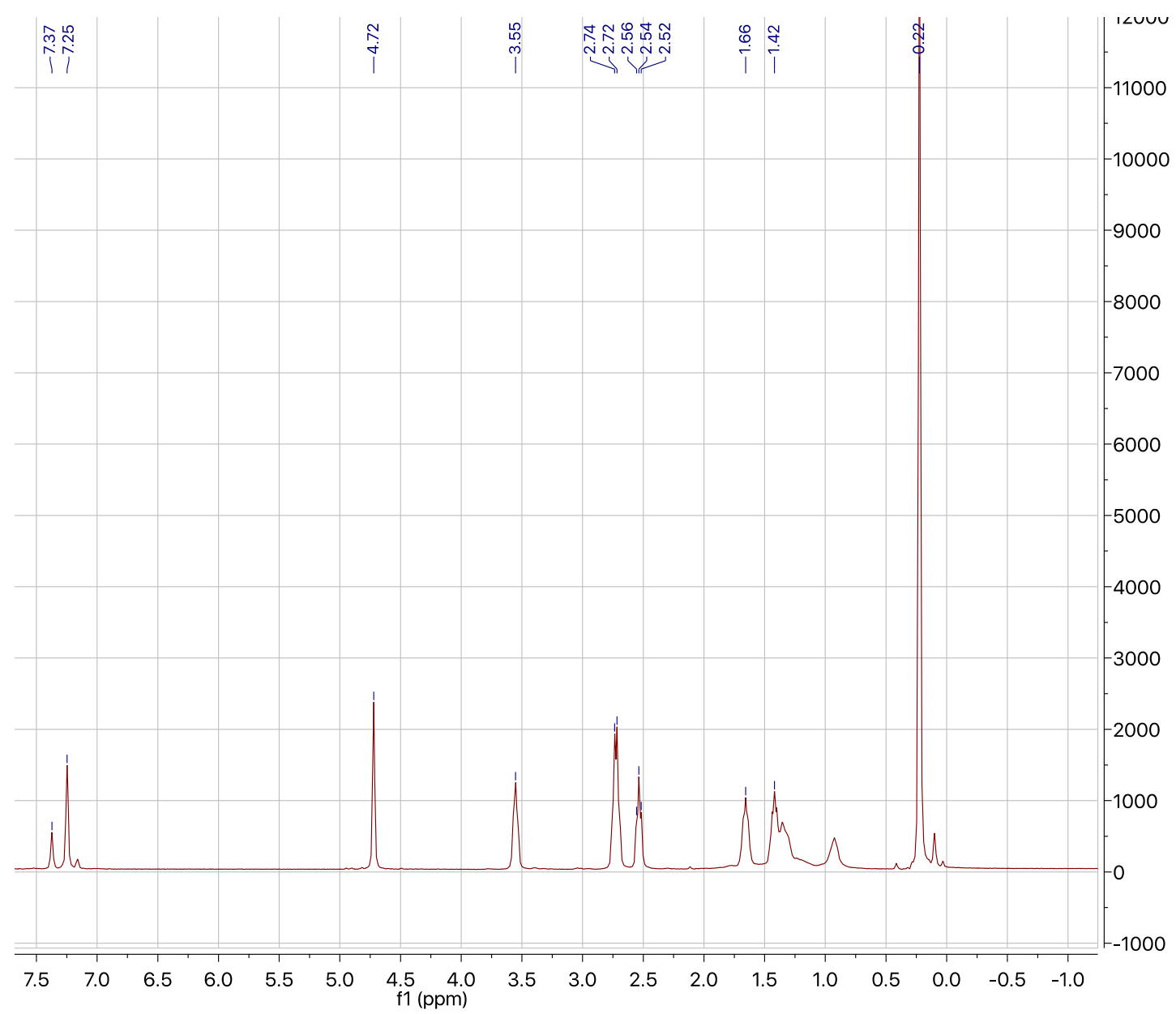




\section{Compound 13}

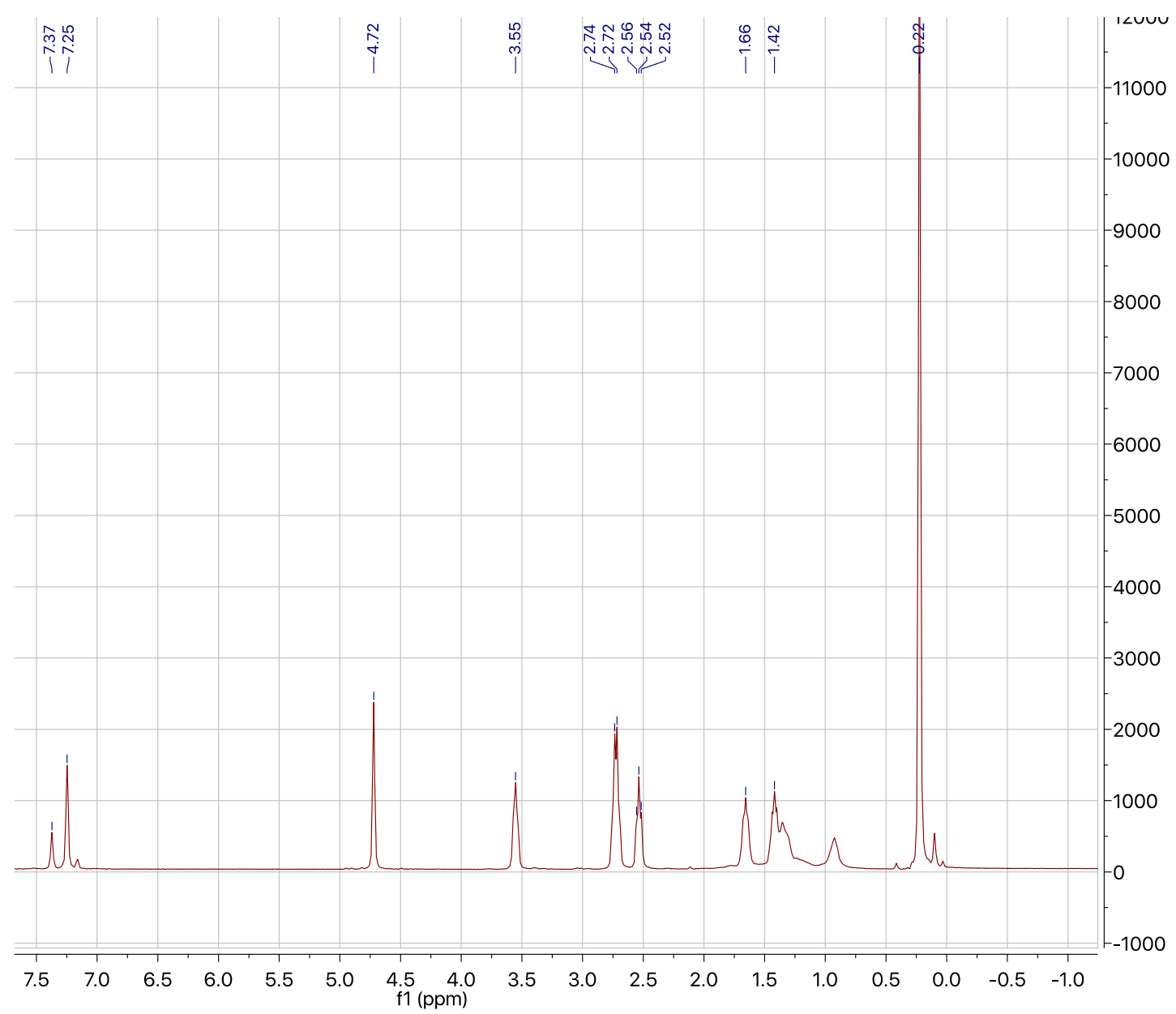


Compound 14

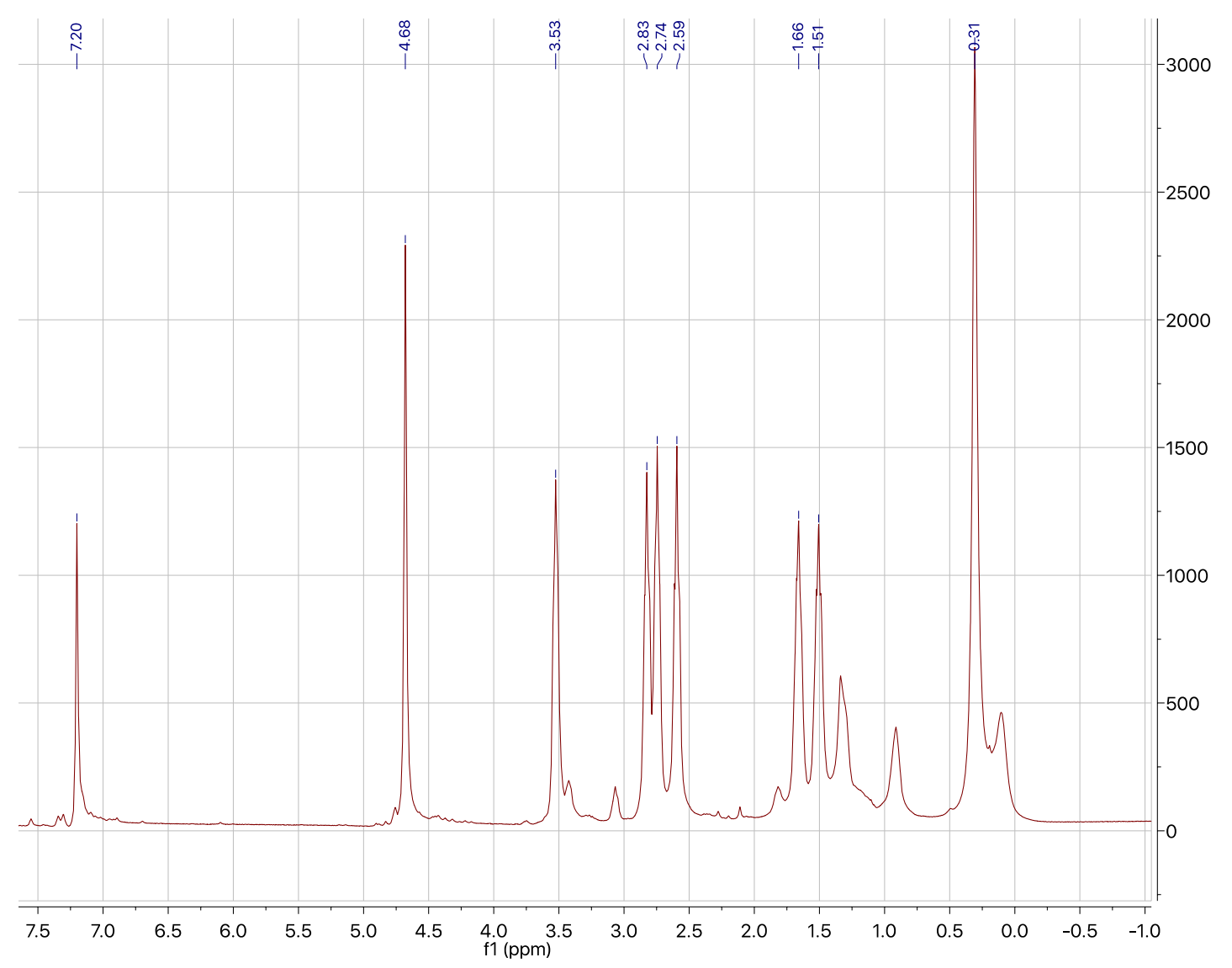




\section{Compound 16}

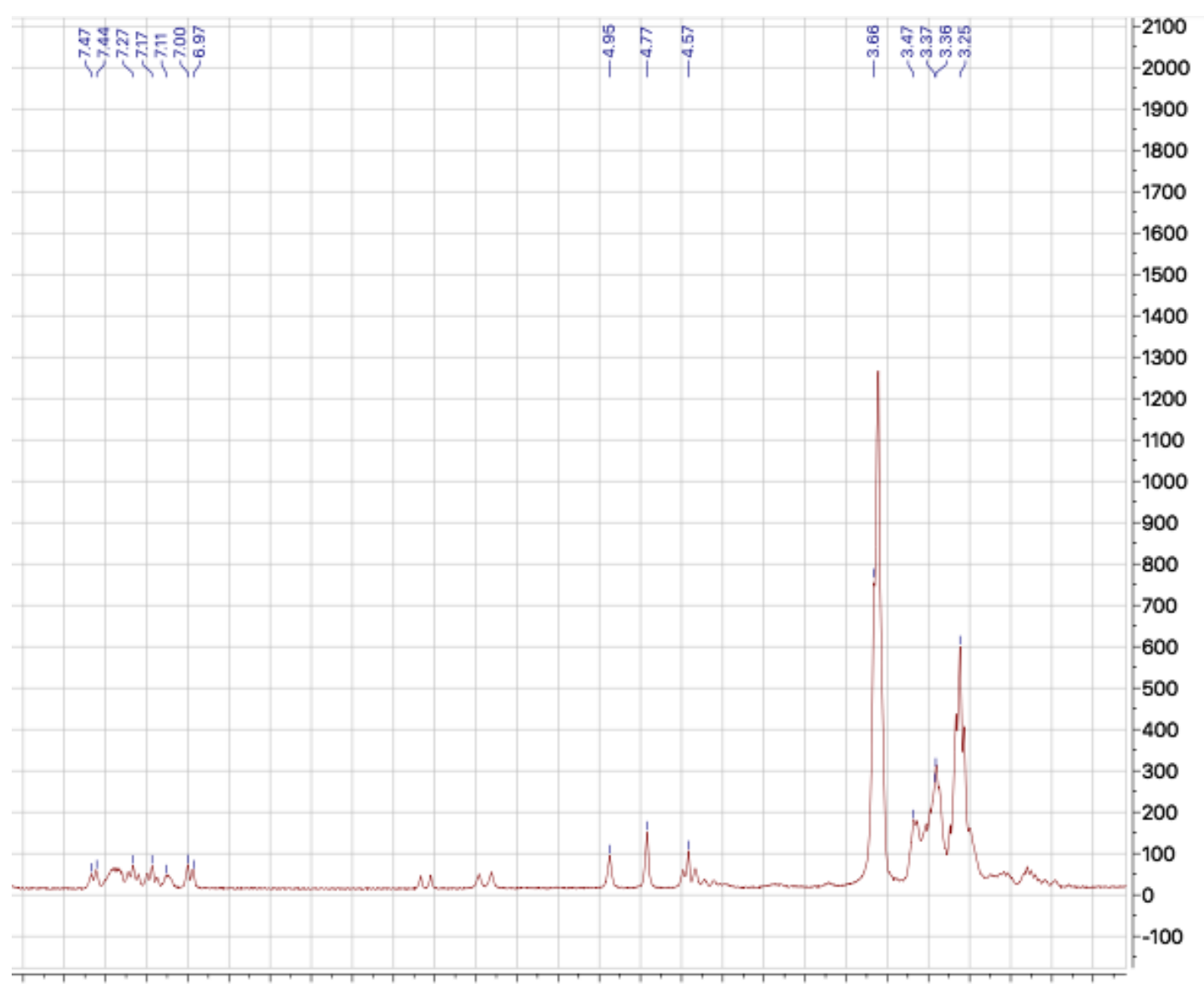

$\begin{array}{lllllllllllllllllllllllllllll}7.8 & 7.6 & 7.4 & 7.2 & 7.0 & 6.8 & 6.6 & 6.4 & 6.2 & 6.0 & 5.8 & 5.6 & 5.4 & 5.2 & 5.0 & 4.8 & 4.6 & 4.4 & 4.2 & 4.0 & 3.8 & 3.6 & 3.4 & 3.2 & 3.0 & 2.8 & 2.6\end{array}$ f1 (ppm) 
Compound 23

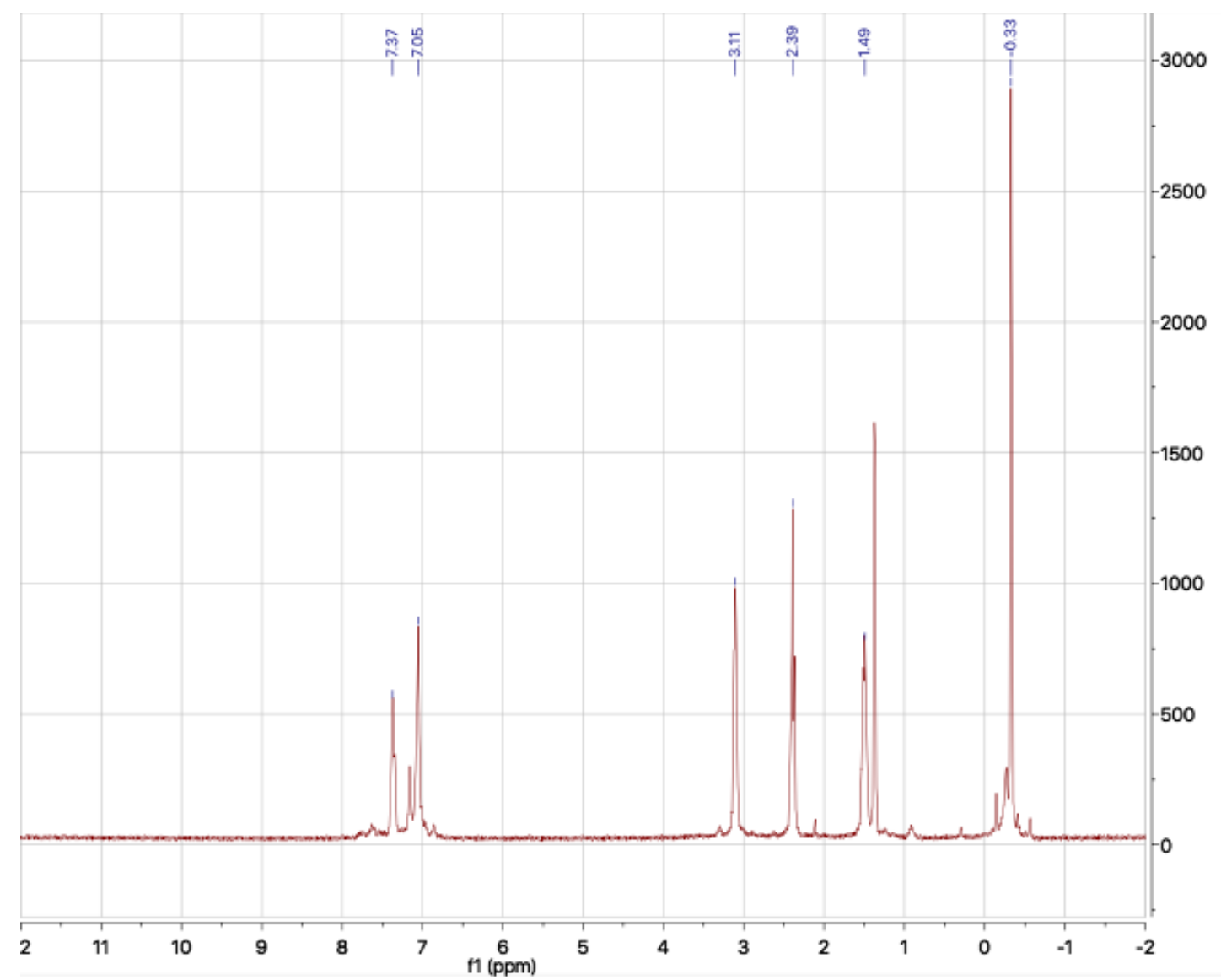


31P NMR for Compound 23:

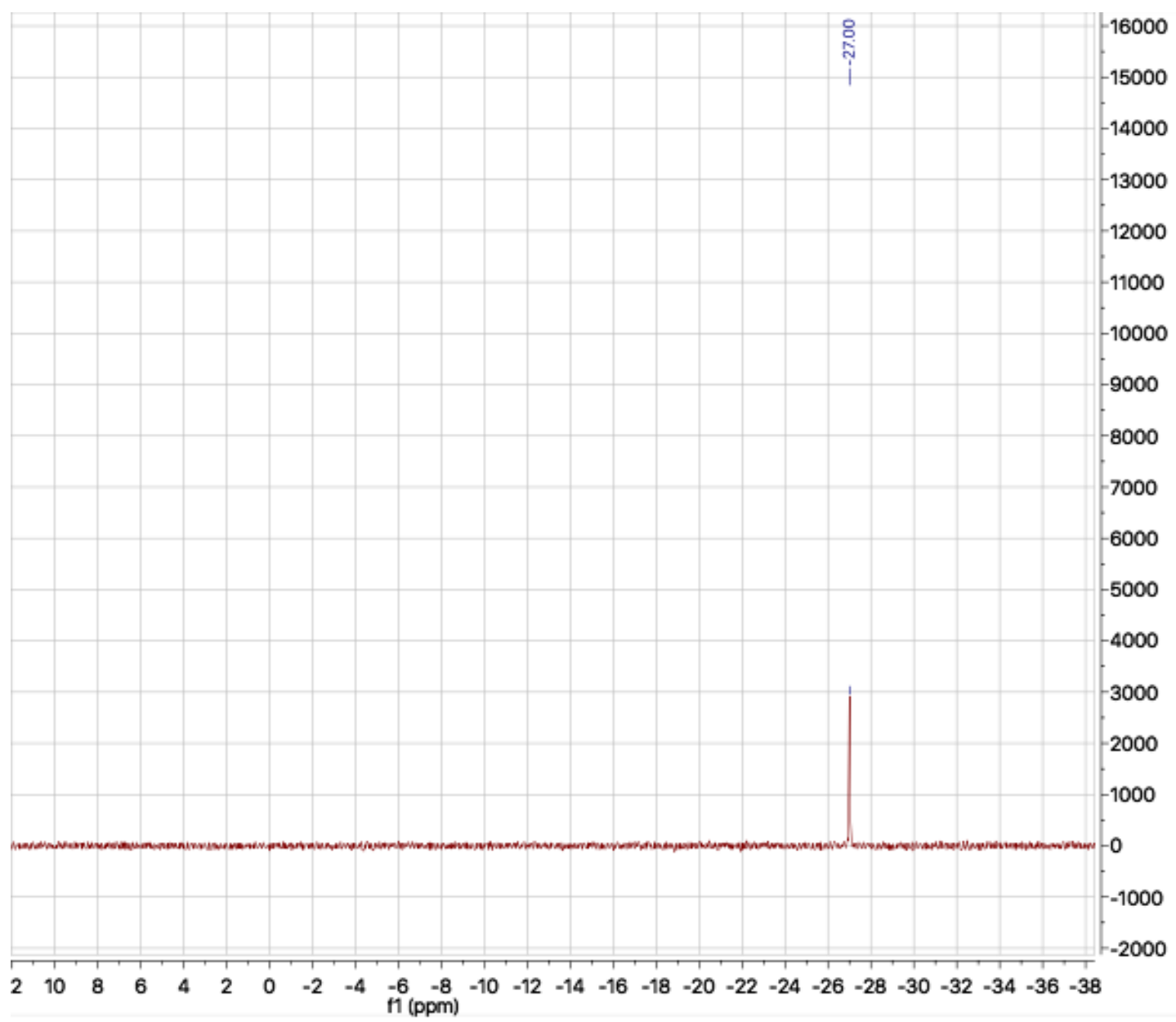

